FELIPE SERAFIM ALBALADEJO

DESENVOLVIMENTO DE UMA UNIDADE DE GERENCIAMENTO

ELETRÔNICO PARA MOTORES DE COMBUSTÃO INTERNA DO CICLO OTTO 


\title{
DESENVOLVIMENTO DE UMA UNIDADE DE GERENCIAMENTO ELETRÔNICO PARA MOTORES DE COMBUSTÃO INTERNA DO CICLO OTTO
}

\author{
Dissertação de Mestrado \\ apresentada ao Curso de Pós \\ Graduação em Microeletrônica da \\ Escola Politécnica da Universidade \\ de São Paulo, como requisito parcial \\ para obtenção do Título de Mestre \\ em Engenharia. \\ Área de Concentração: \\ Engenharia Elétrica \\ Orientador: Professor Doutor \\ Alexsander Tressino de Carvalho
}


FICHA CATALOGRÁFICA

\section{Albaladejo, Felipe Serafim}

Desenvolvimento de uma unidade de gerenciamento eletrônico para motores de combustão interna do ciclo OTTO / F.S. Albaladejo. -- São Paulo, 2013.

$142 \mathrm{p}$.

Dissertação (Mestrado) - Escola Politécnica da Universidade de São Paulo. Departamento de Engenharia de Sistemas Eletrônicos.

1.Motores de combustão interna 2. Eletrônica embarcada I.Universidade de São Paulo. Escola Politécnica. Departamento de Engenharia de Sistemas Eletrônicos II.t. 


\section{AGRADECIMENTOS}

Ao Professor Doutor Alexsander Tressino de Carvalho por me orientar e estar presente não só como orientador, mas também como amigo, sendo sempre uma pessoa muito sensata com boas sugestões, críticas, elogios e apoios durante todos os momentos de elaboração dessa dissertação.

Ao Professor Doutor Armando Antonio Maria Laganá, pela vasta experiência trocada ao longo do desenvolvimento desse trabalho, pelas sábias opiniões e orientações que foram a mim passadas e pelo tempo investido em muitos finais de semana que passamos juntos no desenvolvimento da parte prática dessa dissertação.

Um agradecimento especial a todos os integrantes da minha família: minha mãe Neide Aparecida Serafim por me apoiar, me dar forças e sugestões sábias durante todo o período de desenvolvimento desse projeto, minhas irmãs Larissa Serafim Albaladejo e Natália Serafim Albaladejo por revisarem os textos da minha dissertação e artigos e por estarem sempre ao meu lado dispostas a auxiliar no que fosse necessário, ao meu vô Marino Serafim e minha vó Aparecida Ribeiro Massarico Serafim pelo amor, conselhos, ajudas em tarefas manuais e caseiras e pelo empréstimo de ferramentas essenciais, como por exemplo, um carro para minha locomoção que muitas vezes reduzia o meu tempo de percurso consideravelmente.

À FATEC Santo André, por ceder seu espaço físico, laboratórios, ferramentas e equipamentos para o desenvolvimento prático desse projeto.

Aos professores da FATEC Santo André Marco Aurélio Fróes, Edson Caoru Kitani e Fábio Delatore, pelas discussões, sugestões e revisões que fizeram no desenvolvimento desse projeto, proporcionando melhores resultados.

Aos colegas de laboratório Marcos Antonio Carvalho Guedes, Bruno Martim de Alcântara Dias, Cynthia Thamires da Silva, Bruno Silva Pereira, André Masakazu Ferreira Soares e Vitor Saiki Scarpinetti, pelos auxílios prestados no desenvolvimento desse projeto.

A Lívia Ferreira Linhares Hora, por estar sempre ao meu lado, prestativa,amorosa, apoiando-me e compreendendo minha ausência em muitos finais de semanas, feriados e momentos importantes que precisaram ser investidos nessa dissertação. 
Aos amigos que permaneceram próximos compreendendo a importância dessa etapa em minha vida e me deram força e apoio para a finalização desse projeto.

Por fim, a todos que colaboraram direta ou indiretamente, na execução desse trabalho. 
"No inicio eu olhava ao redor e não pude encontrar o carro que eu sonhava, Então, eu decidi construí-lo" Dr.Ing. h.c. Ferry Porshe 


\section{RESUMO}

Este trabalho foca no desenvolvimento de uma unidade de gerenciamento eletrônico que tem como objetivo controlar um motor de combustão interna do ciclo Otto. Essa unidade é composta por três blocos independentes, onde cada um deles é composto por um hardware e um software específico. O primeiro bloco é chamado de gerenciamento e ele é responsável por ler todos os sinais de sensores, processá-los e criar com isso alguns parâmetros de controle que são transmitidos para o bloco de sincronismo por meio de uma comunicação SPI (Synchronous Peripheral Interface). O bloco de sincronismo por sua vez recebe esses parâmetros com a intenção de controlar as válvulas injetoras e as bobinas de ignição no momento exato para manter o motor em um funcionamento perfeito. O terceiro bloco é chamado comunicação/diagnose, sendo responsável por ser a interface entre o motor e os usuários e desenvolvedores. Portanto, ele monitora algumas informações do motor e as mostram em um display, bem como possíveis falhas que possam ocorrer na utilização dele. Sendo assim, o objetivo principal desse trabalho é mostrar como essa unidade de gerenciamento eletrônico foi desenvolvida, algumas estratégias usadas para controlar o motor e alguns resultados práticos aplicando essa unidade de gerenciamento eletrônico em um motor real montado em uma plataforma de metal chamado mock-up.

Palavras- chave: Unidade de Gerenciamento Eletrônico. Gerenciamento. Sincronismo. Mock-up. Motor de Combustão Interna. 


\begin{abstract}
This paper focuses on the development of an electronic management unit which has the objective to control an Otto cycle internal combustion engine. This unit is composed by three separated blocks where each one of these blocks is composed by one specific hardware and software. The first block is named management and it is responsible to read all the engine sensors signals, to process these signals and to create with it some parameters of control that is transferred to the synchronism block through a SPI (Synchronous Peripheral Interface) communication. The synchronism block receives these parameters in order to control the nozzles and the ignition coils in the exact moment to keep the engine running perfectly. The third block is named communication/diagnoses and it is responsible to be the interface between the engine and the drivers and developers. So it monitores some engine information and it shows this information in a display, as well some possible faults that can occur with the use of it. Therefore, the main purpose of this work is to show how this electronic control unit was developed, some strategies used to control the engine and some practical results, by applying this electronic control unit in a real engine assembled in an iron base platform, named mock-up.
\end{abstract}

Keywords: Electronic Management Unit. Management. Synchronism. Mock-up. Internal Combustion Engine. 


\section{LISTA DE ILUSTRAÇÕES}

Figura 1 - Réplica do primeiro veículo construído por Benz localizada na Autostadt

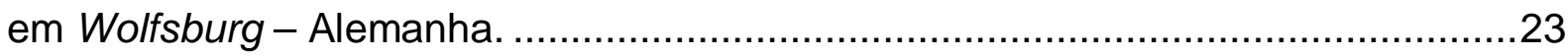

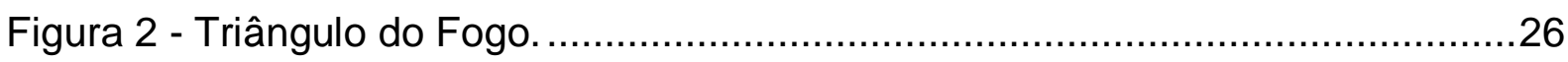

Figura 3 - Circuito de admissão de ar........................................................27

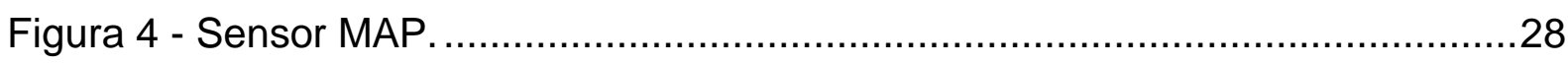

Figura 5 - Sensor MAP no coletor de Admissão com o motor desligado...................29

Figura 6 - Sensor MAP no coletor de Admissão com o motor em funcionamento. ...30 Figura 7 - Circuito eletrônico básico de condicionamento de sinal para o sensor MAP.

Figura 8 - Curva de Reposta do sensor MAP..............................................31

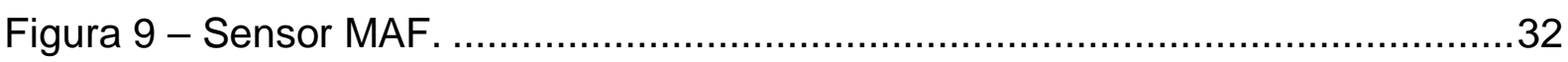

Figura 10 - Principio físico do sensor de fio quente.......................................33

Figura 11 - Circuito eletrônico de condicionamento do sensor MAF. .....................34

Figura 12 - Resistência NTC em conjunto com o sensor MAP (vista em corte)........36

Figura 13 - Curva de resposta do sensor de Temperatura do Ar Admitido...............36

Figura 14 - Roda Geradora de Impulsos. ...................................................

Figura 15 - Sinal de tensão de saída de um sensor indutivo..................................39

Figura 16 - A) Elemento hall sem aplicação de campo magnético. B) Elemento hall com aplicação de campo magnético. .....................................................40

Figura 17 - Circuito Integrado Hall do sensor de rotação. .....................................41

Figura 18 - Circuito eletrônico de condicionamento do sinal do sensor Hall. ...........42

Figura 19 - Sinal de saída do condicionador de sinal do sensor Hall. ......................42

Figura 20 - Corpo de Borboleta com destaque no sensor de posição.....................43

Figura 21 - llustração de um sistema de injeção eletrônica monoponto...................47

Figura 22 - Ilustração de um sistema de injeção eletrônica Multiponto. ...................47

Figura 23 - Gases de Escape de um Motor Ciclo Otto. .....................................50

Figura 24 - Gráfico dos gases de emissões relacionados com o fator lambda. ........51

Figura 25 - Pressão de combustão com ocorrência de knocking...........................54

Figura 26 - Gráfico do tempo de injeção x a temperatura do motor. .........................56 
Figura 27 - Gráfico de demonstração do cut off por uma rotação muito elevada do motor.

Figura 28 - Motor doado pela GM utilizado na confecção do Mock-up. ....................60

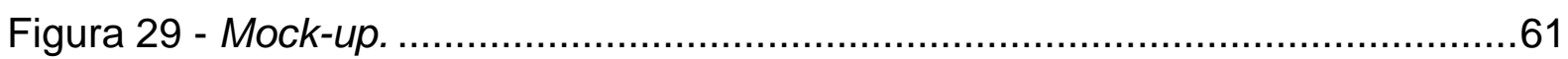

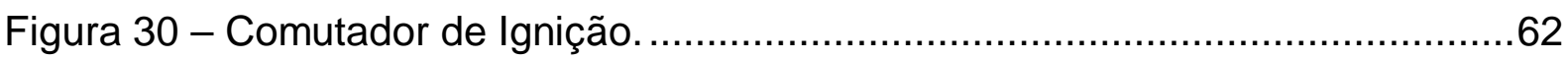

Figura 31 -A) Mock-up com chicote elétrico original. B) Mock-up com chicote elétrico

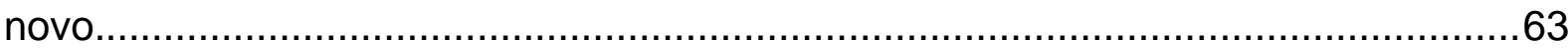

Figura 32 - Diagrama de blocos da intersecção os sensores e atuadores da ECU. .64 Figura 33 - A) Primeira intersecção com a caixa de acrílico, B) Segunda versão da

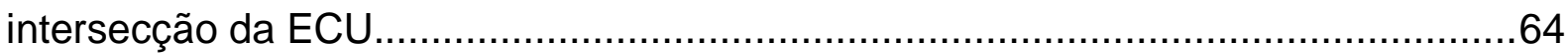

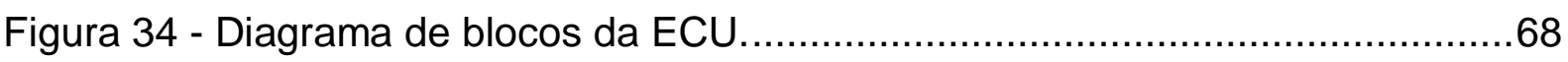

Figura 35 - Distribuição dos pinos no microcontrolador de gerenciamento da primeira

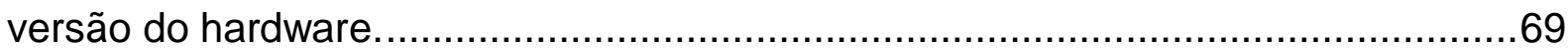

Figura 36 - Circuito de condicionamento dos sensores analógicos.........................70

Figura 37 - Circuito de condicionamento dos sensores digitais..............................70

Figura 38 - Circuito condicionador do sensor de relutância variável. ........................72

Figura 39 - Diagrama simplificado de aplicação da interface da válvula borboleta. .72

Figura 40 - Distribuição dos pinos no microcontrolador de gerenciamento da

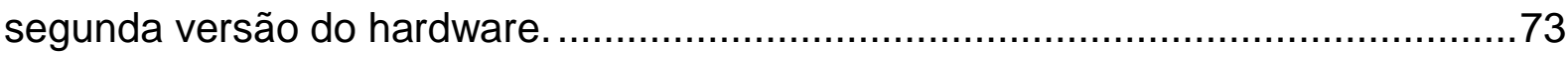

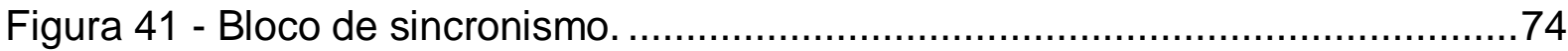

Figura 42 - Circuito de comando das válvulas injetoras ......................................75

Figura 43 - Diagrama de funcionamento do circuito de interface MC $33810 \ldots \ldots \ldots \ldots . .76$

Figura 44 - Circuito de comando das bobinas de ignição......................................77

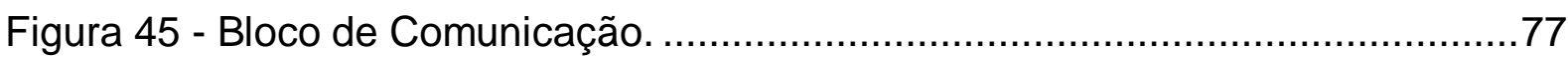

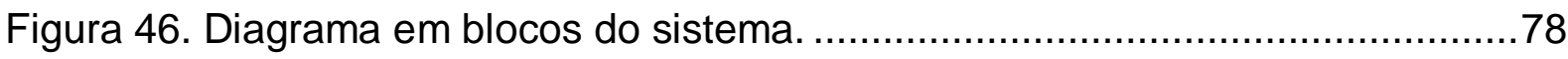

Figura 47 - Carta de tempos do módulo de gerenciamento. ..................................79

Figura 48- Carta de tempos do módulo de sincronismo.........................................

Figura 49 - Fluxograma da primeira fase do programa. .......................................

Figura 50 - Fluxograma da segunda fase do programa principal de gerenciamento. 82

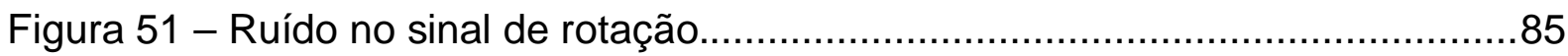

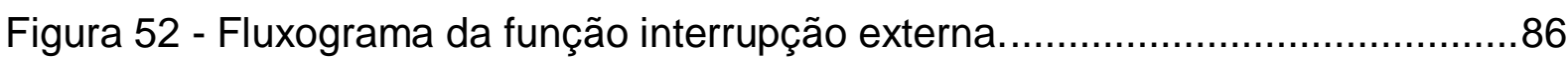

Figura 53 - Sequência de eventos na função conta dente.......................................89

Figura 54 - Fluxograma da função de interrupção do Timer 0 ...................................91

Figura 55 - Fluxograma da função conta dente.................................................100 
Figura 56 - Fluxograma do Sistema de Ignição................................................102

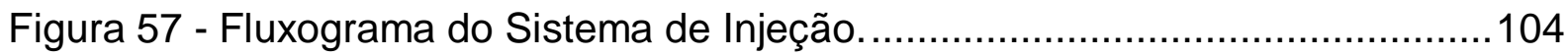

Figura 58 - Plataforma utilizada para testes inicias do projeto. .............................105

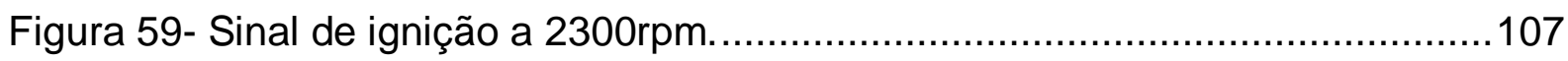

Figura 60. Sinal de ignição a 4500rpm.........................................................107

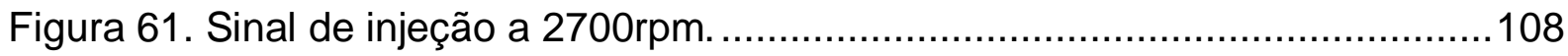

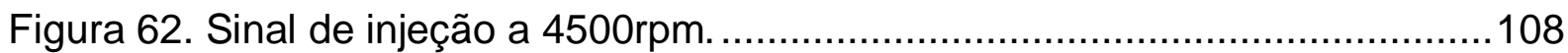

Figura 63 - Esquemático de ligações do circuito de testes..................................109

Figura 64 - Comparação entre sinal de injeção da válvula injetora do primeiro cilindro da ECU original e da ECU desenvolvida.

Figura 65 - Comparação entre sinal de injeção da válvula injetora do segundo cilindro da ECU original e da ECU desenvolvida.

Figura 66 - Comparação entre sinal de injeção da válvula injetora do terceiro cilindro da ECU original e da ECU desenvolvida.

Figura 67- Comparação entre sinal de injeção da válvula injetora do terceiro cilindro da ECU original e da ECU desenvolvida.

Figura 68 - Comparação entre sinal de ignição das velas do segundo e terceiro cilindros da ECU original e da ECU desenvolvida.

Figura 69 - Comparação entre sinal de ignição das velas do primeiro e quarto cilindros da ECU original e da ECU desenvolvida.

Figura 70 - Sinal capturado no osciloscópio no momento de partida do motor.

Figura 71 - Sinal capturado no osciloscópio em regime de marcha lenta do motor.115 Figura 72 - Sinal capturado no osciloscópio em regimes de aceleração e desaceleração do motor. 


\section{TABELA}

Tabela 1 - Comparação da Tensão com o Fluxo de Ar. .........................35

Tabela 2 - Relação A/C estequiométrica em função do combustível ....49

Tabela 3 - Parâmetros Recebidos via Comunicação SPI. ...................101 


\section{LISTA DE ABREVIATURAS E SIGLAS}

ABS Anti-lock Breaking System

A/C Ar/Combustível

$\mathbf{A} / \mathbf{C}_{(\mathbf{s})} \quad$ Relação Ar/Combustível estequiométrica

A/D Analógico/Digital

CAN Controller Area Network

Cl Circuito Integrado

$\mathrm{CO}_{2} \quad$ Dióxido de Carbono

ECU Electronic Control Unit

EFI Electronic Fuel Injection

ETC Electronic Throttle Control

EPUSP Escola Politécnica da USP

FATEC Faculdade de Tecnologia do Estado de São Paulo

GM General Motors

GMB General Motors do Brasil

$\mathrm{H}_{2} \mathrm{O} \quad$ Molécula da água

IAT Intake Air Temperature

KW Quilowatt

LCD Liquid Cristal Display

LED Light Emitting Diode

LIN Local Interconnect Network

MAF Mass Air Flow

MCI Motor de Combustão Interna

MAP Manifold Absolute Pressure

MEMS Microelectromechanical Systems

mm milímetros

MM Massa Molar

MOST Media Oriented Systems Transport

ms milisegundos

NTC Negative Temperature Coefficient

$\mathbf{O}_{2} \quad$ Oxigênio presente no ar atmosférico 
PTC Positive Temperature Coefficient

rpm Rotações por minuto

SPI Synchronous Peripheral Interface

TBI Throttle Body Injection

TPS Throttle Position Sensor

USART Universal Synchronous and Asynchronous Receiver Transmitter

USP Universidade de São Paulo 


\section{LISTA DE SÍMBOLOS}

$\begin{array}{ll}\boldsymbol{\rho} & \text { Densidade } \\ \boldsymbol{\eta} & \text { Massa molar } \\ \boldsymbol{A}_{\text {th }} & \text { Área de abertura da válvula borboleta } \\ \boldsymbol{\Psi}_{\mathbf{0}} & \text { Ângulo da válvula borboleta na posição fechada } \\ \boldsymbol{\Psi} & \text { Ângulo de abertura da válvula borboleta } \\ \boldsymbol{\lambda} & \text { Fator lambda }\end{array}$




\section{SUMÁRIO}

1 INTRODUÇÃO

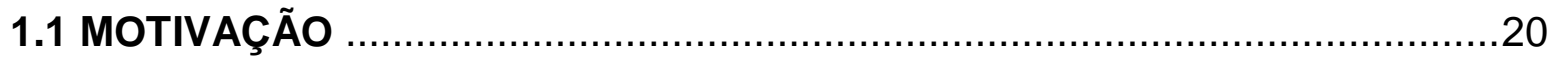

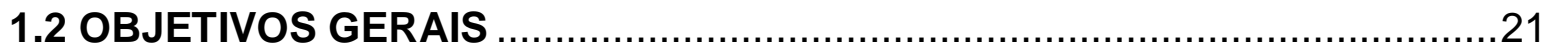

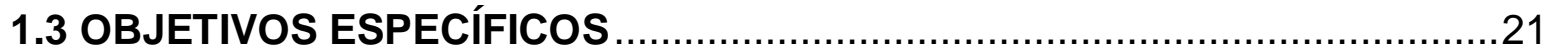

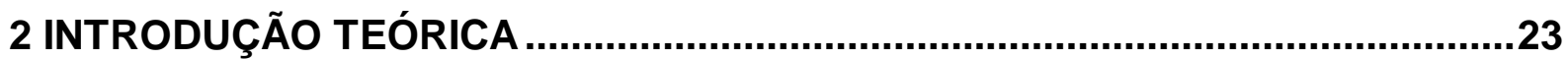

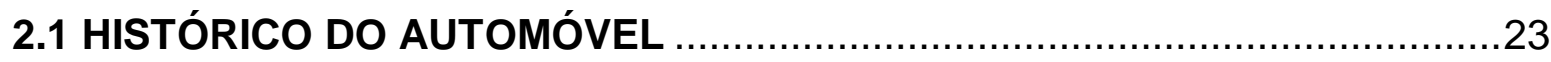

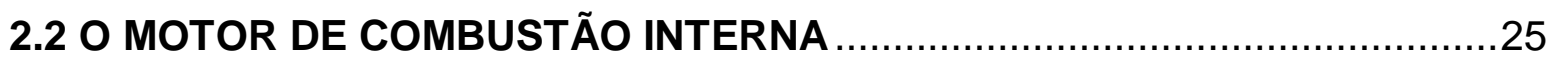

2.2.1 Pré-Requisitos para uma combustão .................................................25

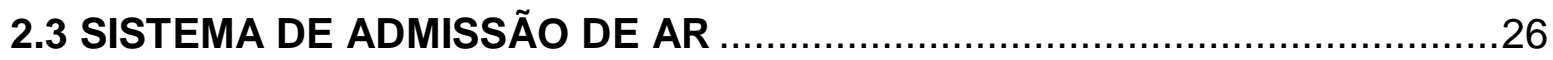

2.3.1 Sensor MAP (Manifold Absolute Pressure) ………...............................28

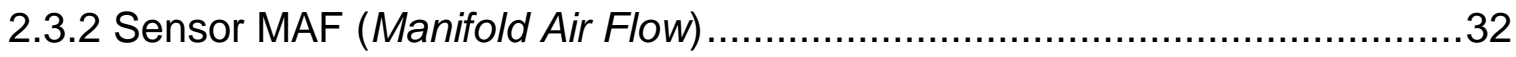

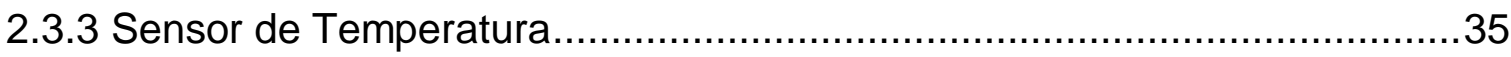

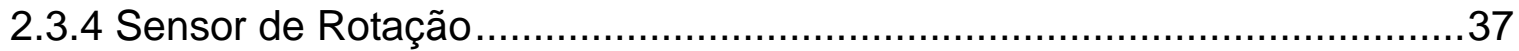

2.3.5 Sensor de Posição da Válvula Borboleta ...............................................42

2.3.6 Equações realizadas para determinar a quantidade de ar admitida............44

2.4 SISTEMA DE ALIMENTAÇÃO DE COMBUSTÍVEL …...................................45

2.5 FORMAÇÃO DA MISTURA AR/COMBUSTÍVEL (A/C) ..............................48

2.5.1 Emissões de Gases de Escape de um Motor Ciclo Otto ............................50

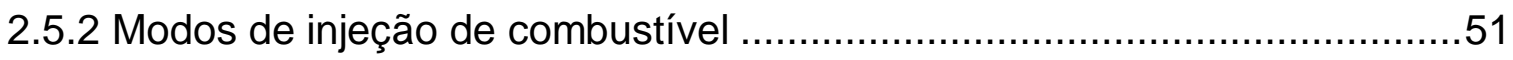

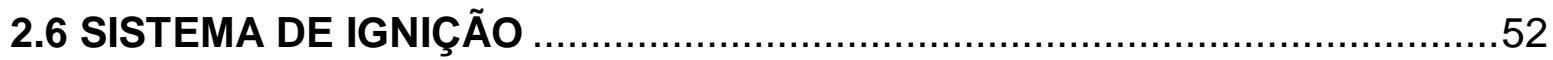

2.7 ESTRATÉGIAS DO GERENCIAMENTO ELETRÔNICO DO MOTOR.............55

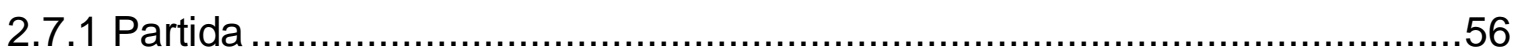

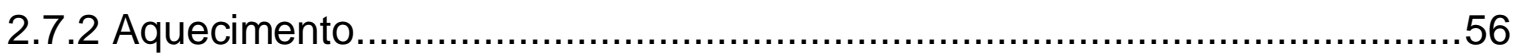

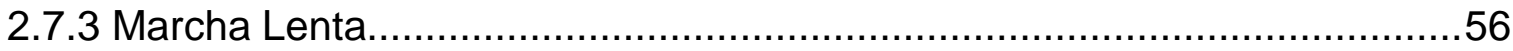

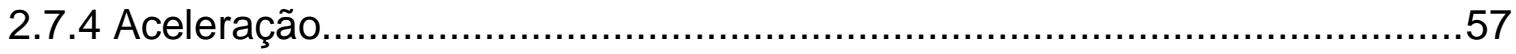


2.7.5 Plena Carga

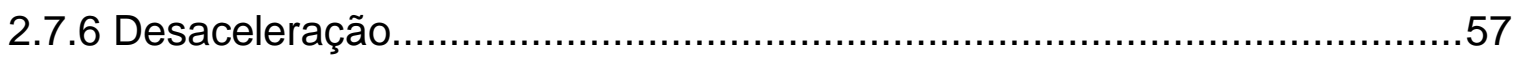

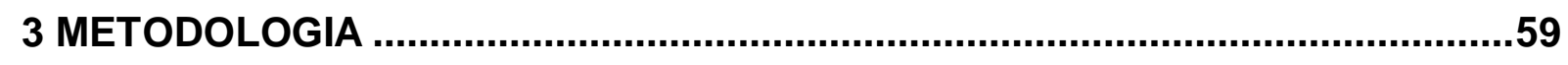

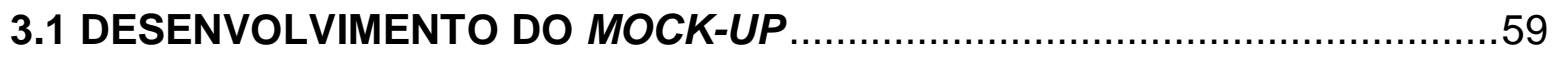

3.1.1 Características Físicas e Eletrônicas do Motor GM ....................................60

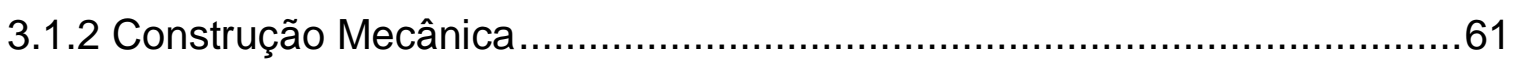

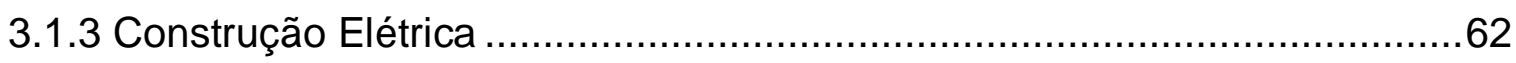

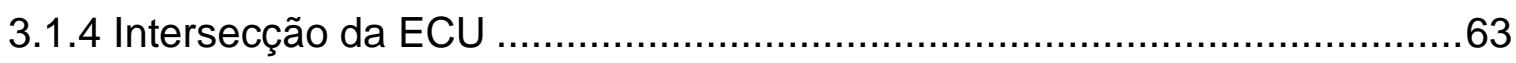

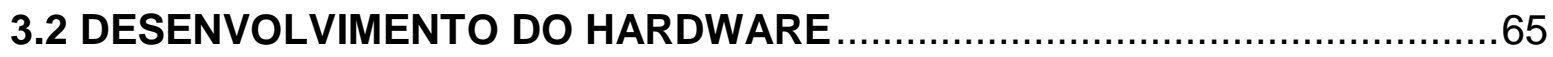

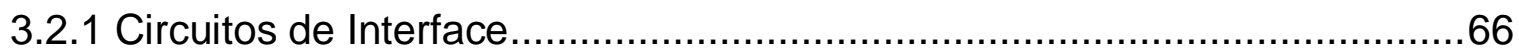

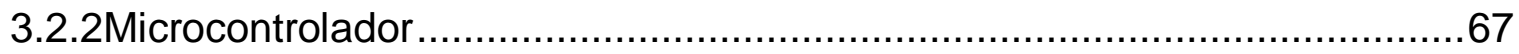

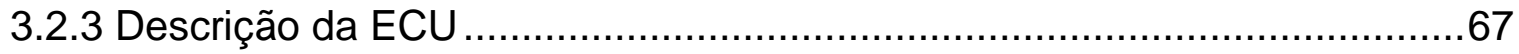

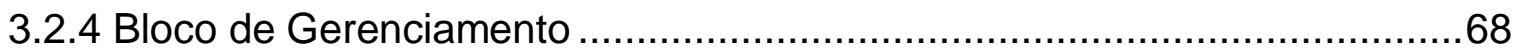

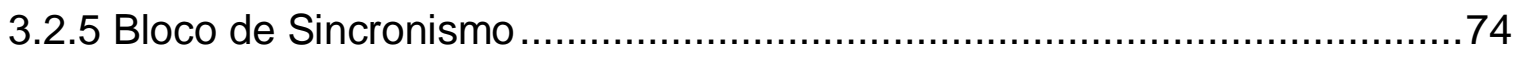

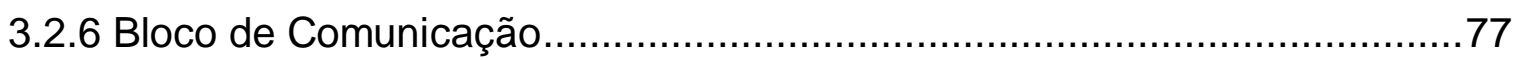

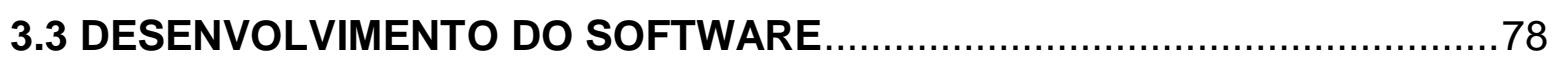

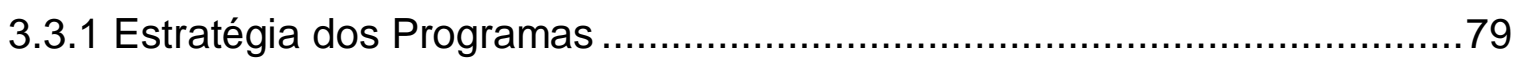

3.3.2 Descrição do Software de Gerenciamento …………..............................

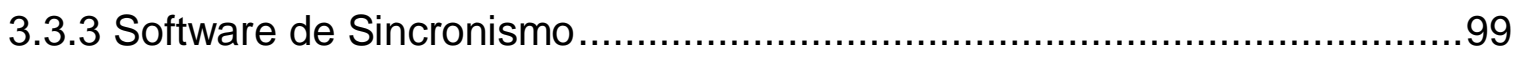

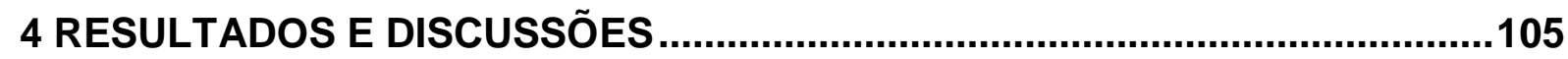

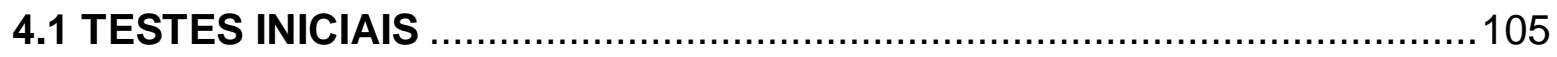

4.1.1 Validação do software de sincronismo, da comunicação SPI e da interface do condicionamento do sinal de rotação do motor ............................................106

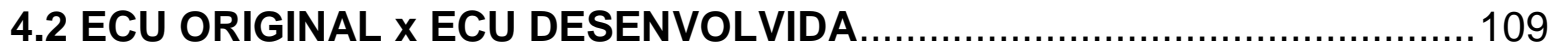

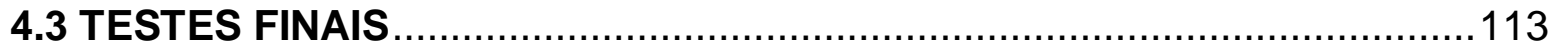

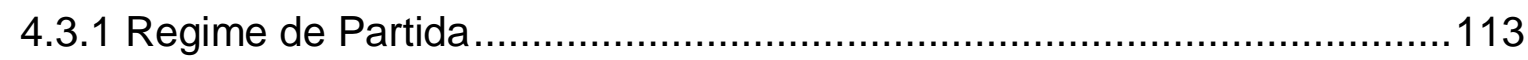

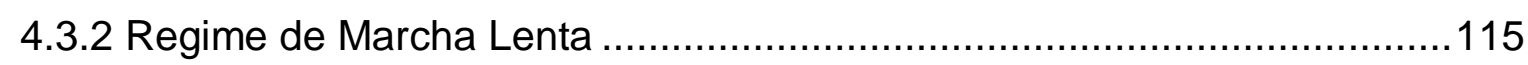


4.3.3 Regime de Aceleração e Desaceleração do Motor 115

5. CONCLUSÃO 117

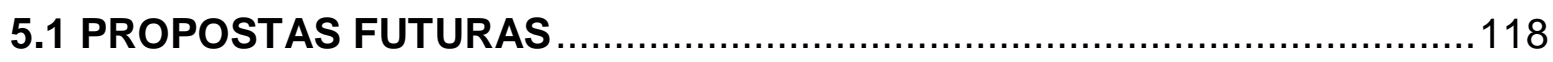

6 REFERÊNCIAS BIBLIOGRÁFICAS ............................................................... 119

ANEXO A - HARDWARE..................................................................... 122

ANEXO B - SOFTWARE ......................................................................... 132 


\section{INTRODUÇÃO}

A evolução no mundo automotivo é contínua e as grandes empresas desse setor buscam sempre lançamentos inovadores em seus produtos para manter-se ativa no mercado. Além disso, a preocupação com a economia de combustível e com a poluição da atmosfera cresce a cada dia, necessitando aplicar novas tecnologias para alcançar um resultado satisfatório na solução desses desafios. Porém, para desenvolver novas soluções na área de motores é necessário primeiramente ter total domínio e controle no funcionamento desse componente. Para isso, além do conhecimento do funcionamento mecânico do motor é necessário o domínio do gerenciamento eletrônico, onde seja possível alterar parâmetros, e dependendo da nova tecnologia a ser testada, até mesmo a programação desse módulo de gerenciamento.

Sendo assim, com o objetivo de auxiliar o desenvolvimento de novas soluções no mercado automotivo no campo de motores a combustão interna este trabalho mostra o desenvolvimento de uma unidade de gerenciamento eletrônico para um motor a combustão interna, onde a partir dessa ferramenta é possível testar novas tecnologias ou controles desenvolvidos com intuito de aprimorar ainda mais máquina térmica.

O presente trabalho teve como objetivo desenvolver uma unidade de gerenciamento eletrônico de um motor a combustão interna com o intuito de controlar totalmente um motor $1.8 \mathrm{GM}$ de 4 cilindros operado com etanol montado em um mock-up.

O desenvolvimento dessa unidade de gerenciamento eletrônico foi dividido em duas etapas: desenvolvimento do hardware e desenvolvimento do software. O desenvolvimento do hardware foi realizado em duas fases: na primeira, foi fabricada uma placa de circuito impresso empregando circuitos integrados mais simples para a implementação das interfaces de condicionamento dos sinais proveniente dos diversos sensores, assim como para as interfaces de controle das válvulas injetoras e bobinas de ignição, com a intenção de familiarizar-se com o controle e o funcionamento de um gerenciamento eletrônico do motor. Na segunda fase foram utilizados circuitos integrados de interfaces fabricadas pela Freescale tanto para os sensores como para os atuadores, tendo em vista minimizar o tamanho da placa, 
aumentar a confiabilidade e facilitar as ações de diagnose. As duas placas estão compostas por circuitos específicos como o de enquadramento do sinal proveniente da roda fônica, interface para a linha CAN (Controller Area Network) e ponte-H para controle da válvula borboleta. Como unidade de processamento, foram utilizados três microcontroladores PIC18F452 da Microchip, descentralizando a unidade de gerenciamento em três blocos: gerenciamento, sincronismo e comunicação/ diagnose.

Este trabalho limitou-se em desenvolver os softwares de controle para os blocos de gerenciamento e sincronismo permitindo assim que outros trabalhos surgissem no controle do bloco de diagnóstico/comunicação. No bloco de gerenciamento, o software de controle tem a função de atuar em alguns componentes básicos do motor (relés, válvula borboleta e etc.), monitorar os sensores (rotação, pressão e temperatura do ar admitido, sonda lambda etc.), calcular e definir parâmetros de controle (tempo de injeção, tempo de carregamento da bobina de ignição, etc.) e transmitir todos esses parâmetros para o bloco de sincronismo. Por sua vez, o software do bloco de sincronismo é responsável por receber os parâmetros enviados pelo gerenciamento, armazenar esses dados em uma matriz e, através do sinal da roda dentada, sincronizar os sinais de comando do sistema de injeção e ignição do motor. Assim, é possível obter um controle do motor em diversos regimes de funcionamento do mesmo permitindo futuros desenvolvimentos e aplicações nessa área de pesquisa.

\subsection{MOTIVAÇÃO}

A motivação para este trabalho decorre inicialmente do forte crescimento da produção de veículos no Brasil ocorrida na última década, ultrapassando a marca de 3 milhões de veículos/ano e disputando com a Índia a sétima posição no ranking mundial. Neste cenário nosso corpo de engenharia tem aumentado significativamente, mas quando o comparamos com outros países produtores de veículos concluímos que nossa engenharia encontra-se aquém do desejado, considerando-se a quantidade de veículos produzida. Esta situação é mais adversa se realizarmos esta análise focada somente na área de eletrônica automotiva. Nesse contexto, a Escola Politécnica da USP e a FATEC Santo André têm dedicado 
esforços no desenvolvimento de uma ECU (Electronic Control Unit) de um motor à combustão interna, visando contribuir na formação de recursos humanos nesta área e criar uma plataforma para desenvolvimento de novas soluções tecnológicas.

Outro fator que motivou o desenvolvimento desse trabalho foi a criação do grupo de pesquisa composto por professores e alunos da Escola Politécnica de São Paulo e da FATEC Santo André, que tem como um dos objetivos consolidar-se como um grupo de excelência, em pesquisa e desenvolvimento na de Eletrônica Automotiva. Tendo este trabalho um papel fundamental para a evolução desse grupo, tal como a criação de uma unidade de gerenciamento eletrônica conhecida e passível de alterações a qualquer momento.

O domínio dessa unidade de gerenciamento eletrônico é de grande importância, pois uma vez tendo uma ECU com os hardwares e softwares conhecidos, se tornam possíveis a aplicação e testes de novas soluções tecnológicas. Facilidade essa, que a grande maioria dos desenvolvedores na área de eletrônica automotiva não encontra.

\subsection{OBJETIVOS GERAIS}

O objetivo geral desse trabalho é criar uma plataforma de desenvolvimento em gerenciamento de motores, recursos humanos e novas soluções na área de eletrônica embarcada focado especificamente em motores de combustão interna do ciclo Otto.

\subsection{OBJETIVOS ESPECÍFICOS}

Os objetivos específicos desse trabalho são:

- Desenvolver uma unidade de gerenciamento eletrônico capaz de controlar um motor de combustão interna do ciclo Otto sem carga.

- Desenvolver uma plataforma didática capaz de proporcionar uma melhor visualização geral do funcionamento mecânico, elétrico e eletrônico de um motor de combustão interna do ciclo Otto nas aulas do curso de Tecnologia em Eletrônica Automotiva ministrados na FATEC de Santo 
André e nas disciplinas Projetos de Sistemas Embarcados e Circuitos Eletrônicos Automotivos ministrados pela EPUSP, dentro da opção Sistemas Eletrônicos. 


\section{INTRODUÇÃO TEÓRICA}

Neste capítulo faz-se um breve histórico sobre a evolução dos automóveis, além de descrever detalhes de um motor de combustão interna tais como: componentes, ciclos de trabalho e funcionamento dos diferentes regimes em que um motor pode trabalhar. Ao longo do texto serão descritas as estratégias de controle empregadas no gerenciamento eletrônico de um motor para cada um desses regimes.

\subsection{HISTÓRICO DO AUTOMÓVEL}

Dentre as diversas máquinas térmicas desenvolvidas ao longo da história, uma das mais utilizadas atualmente é o motor de combustão interna. O seu desenvolvimento iniciou-se com os primeiros motores a vapor, desenvolvidos e construídos pelos jesuítas franceses Ferdinand Verbeist e Philippe Marie Grimaldi na China em 1665 (FLINK, 1990). Contudo, com a exploração do petróleo anos mais tarde houve o ápice das mudanças em um motor de combustão interna: a substituição do combustível em forma gasosa pelo combustível em forma líquida (CÂMARA, 2006).

Pesquisas sobre motores a combustão interna foram intensificadas desde então e motores a vapor se tornaram obsoletos. Com isso, em 1876, Nikolaus Otto construiu o primeiro motor a combustão interna da história movido por uma sequência de quatro ciclos de trabalho: admissão, compressão, combustão e escape (MILHOR, 2002).

Embora Otto tenha sido o inventor do motor a combustão interna, ele não o inseriu em um automóvel, deixando essa tarefa para que Gottilieb Daimler e Carl Benz executassem-na, separadamente (cada um criando um protótipo diferente do outro), criando com isso um novo conceito de automóvel. (Figura 1) (FLINK, 1990).

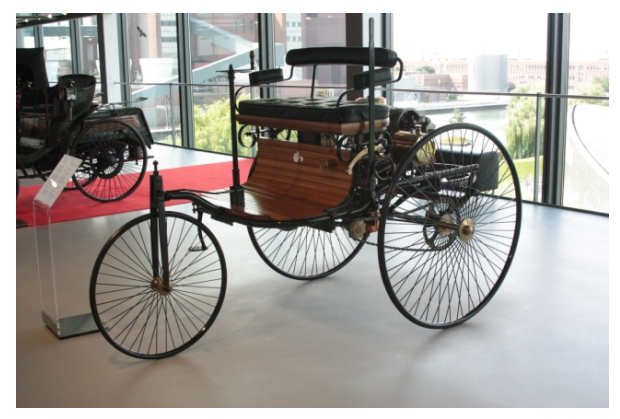

Figura 1 - Réplica do primeiro veículo construído por Benz localizada na Autostadt em WolfsburgAlemanha. 
Com a introdução desse novo produto no mercado novas empresas surgiram para competir com Benz e Daimler, tornando o mercado automotivo mais competitivo e provocando uma evolução natural desse produto.

Entre essas evoluções, algumas montadoras, primeiramente as europeias e depois as japonesas e americanas respectivamente, introduziram um conceito diferente de controle nos motores dos veículos. Eles separaram o módulo de controle do sistema de ignição (distribuidor) e injeção (carburador), iniciando uma inserção de componentes eletrônicos nesses sistemas. Primeiro, por volta de 1966 foi usada uma injeção eletromecânica para melhorar a dinâmica dos gases que entravam nos cilindros. Contudo, nessa época o mundo começou a se despertar para os assuntos ambientais, iniciando campanhas e leis no mundo todo contra emissões de poluentes. Isso se refletiu fortemente no setor automotivo, pois os gases resultantes da queima da mistura ar combustíveis contribuíam significativamente para a poluição da atmosfera. Foi então que as indústrias automobilísticas começaram a se preocupar não somente com conforto, segurança e economia de combustível, mas também a partir de então com o índice dos gases poluentes que estavam sendo emitidos na atmosfera (AMEY, 1995).

Com essa nova tendência todas as soluções tecnológicas inventadas até aquele momento não eram suficientes para atender todos os requisitos necessários para atingir tanto as leis ambientais quanto as exigências dos consumidores. Foi então que o carburador eletrônico foi inventado, pois ele tinha um simples sistema de controle eletrônico para a dosagem de combustível que mais tarde, nos anos 70, foi substituído pelo corpo de borboleta TBI (Throttle Body Injection) (AMEY, 1995).

Contudo, somente o TBI não foi o bastante para alcançar os resultados necessários. Portanto, com a criação dos microcontroladores e microprocessadores nos anos 80 a injeção eletrônica monoponto (com apenas uma válvula injetora) solucionou muitos desses desafios, tais como: o controle de emissões de gases de exaustão e economia de combustível. Obviamente, com ajuda de muitos sensores e atuadores, tais como: a eletroválvula injetora de combustível, motor de passo para controlar a marcha lenta, sensor MAF (Mass Air Flow), sensor lambda entre outros (BEREISA, 1983).

Com a introdução da tecnologia de injeção eletrônica de combustível (EFI Electronic Fuel Injection) nos motores, os carburadores tornaram-se obsoletos e, nos anos 90 , praticamente não existiam mais quebrando o paradigma de que nos 
automóveis os componentes mecânicos eram absolutos. Foi criado também um novo método de controle do motor, utilizando apenas uma unidade de controle eletrônico (ECU - Electronic Control Unit) que recebia e processava os sinais dos sensores, gerando pulsos para comandar alguns atuadores.

Dessa forma, os veículos atuais estão emitindo menos gases do que antes e, consequentemente, também se tornaram mais econômicos. Quando a indústria automotiva percebeu esses resultados começou a investir cada vez mais em tecnologia. Como consequência, os veículos se tornaram mais confortáveis, seguros e práticos. Por outro lado, com novas arquiteturas de comunicação (CAN, LIN, Flex Ray e MOST), substituição da injeção monoponto pela multiponto (cada cilindro com seu injetor) ou injeção direta (válvulas injetoras injetando combustível diretamente nos cilindros) e novas invenções como controle da velocidade cruzeiro, airbag, ABS (Anti-lock Breaking System) entre outros, os sistemas de controle eletrônico dos veículos ficaram muito mais complexos.

\subsection{O MOTOR DE COMBUSTÃO INTERNA}

Por definição pode-se dizer que um motor é todo conjunto de peças fixas e móveis que transformam algum tipo de energia em energia mecânica. Com isso é possível afirmar que um motor a combustão interna é um conjunto de peças fixas e móveis que transformam a energia química do combustível em energia de calor (faísca das velas de ignição), que por sua vez transforma essa energia em uma expansão elástica dos gases gerando uma energia mecânica (movimento dos pistões).

\subsubsection{Pré-Requisitos para uma combustão}

Como visto anteriormente, o motor de combustão interna pode ser considerado uma máquina termodinâmica. Segundo Moran e Shapiro (2004) therme do latim significa calor e dynamis significa força. Portanto, termodinâmica significa força proveniente do calor. 
Sendo assim, é possível afirmar que o princípio de funcionamento físico de um motor a combustão interna depende diretamente de um aumento súbito de pressão no interior dos cilindros gerado pela combustão dos gases ali presente. Para que isso ocorra, a reação de três reagentes é necessária:

- Comburente: o oxigênio do ar aspirado;

- Combustível: a gasolina, etanol ou gás natural veicular e,

- Calor: a centelha da vela de ignição.

Esses três reagentes formam um triângulo, chamado de triângulo do fogo (Figura 2), e na ausência de algum deles não é possível obter a combustão. Por isso nas próximas seções cada um desses reagentes será tratado separadamente, detalhando a importância e o controle executado em cada um desses sistemas. Primeiramente com uma descrição do sistema de admissão de ar (comburente), seguindo com explanação sobre o sistema de combustível e posteriormente do sistema de ignição do veículo (fonte de calor).

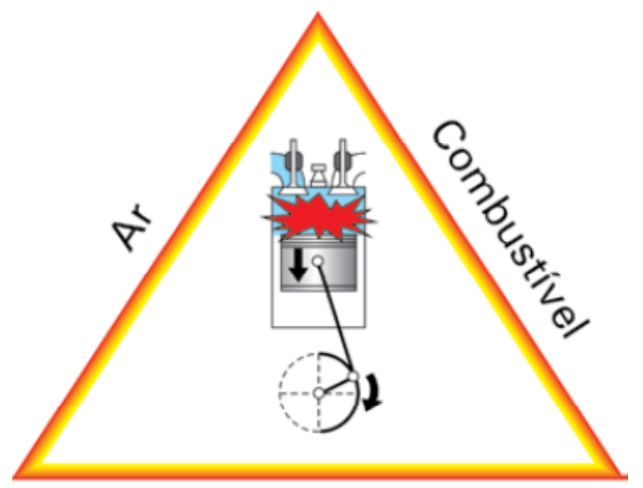

Calor

Figura 2 - Triângulo do Fogo.

(Extraída de VOLKSWAGEN, 2009).

\subsection{SISTEMA DE ADMISSÃO DE AR}

O fluxo de turbulência do ar de admissão nos cilindros de um motor exerce um importante papel na determinação das características da combustão e na eficiência térmica de um motor. Engenheiros automotivos vêm se esforçando para utilizar a turbulência a favor de uma melhor queima da mistura ar combustível, mudando formatos da câmara de combustão e a geometria do sistema de admissão (KANG; BACK, 1998), pois com essa característica, é possível homogeneizar a mistura do ar com o combustível, melhorando a queima dessa mistura, além de acelerar a 
velocidade de admissão dos gases, permitindo um enchimento do volume total dos cilindros em um range maior de rotação e aumentando a velocidade da queima dos gases no interior dos cilindros.

Um cálculo aproximado do tempo de queima de uma mistura ar combustível em um cilindro de $10 \mathrm{~mm}$ de diâmetro com ignição central é de aproximadamente 100 ms. No entanto, para um motor de combustão interna trabalhando a $3000 \mathrm{rpm}$ o ciclo de combustão dura apenas $10 \mathrm{~ms}$. Isto significa que o tempo de propagação da chama, desde o disparo da centelha até a última molécula de ar e combustível queimada em um cilindro sem nenhuma preocupação com a turbulência desses gases, é aproximadamente 10 vezes maior do que o necessário, comprovando dessa forma a importância da turbulência na velocidade de combustão para a otimização do tempo em motores de combustão interna (SILVIO, 2000).

A turbulência é gerada como resultado dos processos de admissão e compressão e da geometria da câmara de combustão. Em adição a isto, se pode gerar um movimento de ar como uma espiral. Isto é obtido com a componente tangencial da velocidade do ar durante a admissão (SILVIO, 2000).

O caminho percorrido pelo ar até chegar ao interior dos cilindros pode ser observado na figura 3 a seguir.

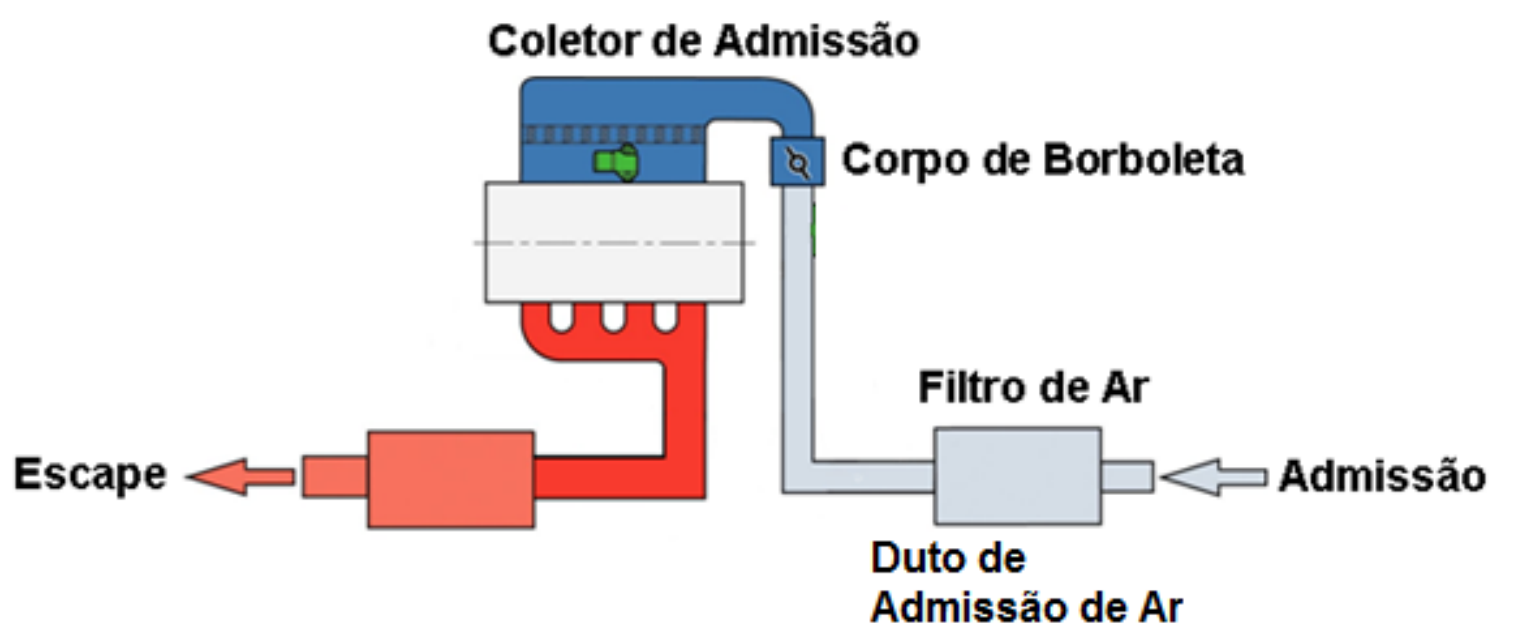

Figura 3 - Circuito de admissão de ar.

(Extraído e adaptado de VOLKSWAGEN, 2009).

Observando o circuito de admissão de ar, ilustrado na figura 3, é possível encontrar quatro componentes mecânicos básicos para o funcionamento adequado da admissão de ar no sistema, são eles: o filtro de ar, o duto de admissão, a válvula borboleta e o coletor de admissão. $O$ filtro de ar retira impurezas do ar atmosférico antes que ele seja admitido. $O$ duto de admissão tem a função de guiar $\mathrm{o}$ ar até a 
válvula borboleta, que por sua vez tem a função de restringir a passagem de ar, com o intuito de controlar indiretamente a quantidade de torque fornecido ao motor, sendo a válvula borboleta controlada nos veículos atuais através de comandos da unidade eletrônica de controle do motor.

O coletor de admissão tem a função, juntamente com a válvula borboleta e câmara de combustão, de criar uma turbulência no ar. É também o local onde é feito a mistura do ar com o combustível em veículos com injeção indireta. Além disso, o coletor de admissão é utilizado como um "reservatório" de depressão nos motores que não possuem bomba de vácuo.

Apesar de esses componentes mecânicos serem essenciais para 0 funcionamento do sistema como um todo, nos motores atuais existem sensores que tem um papel extremamente importante. Eles monitoram a admissão de ar com objetivo de quantificar a densidade do ar admitido para dentro dos cilindros. Portanto, serão descritos nas próximas subseções quais são esses sensores e algumas características dos mesmos.

\subsubsection{Sensor MAP (Manifold Absolute Pressure)}

Com objetivo de medir a quantidade do fluxo de ar indiretamente admitida pelos cilindros, o sensor de pressão absoluta MAP (Figura 4) foi a solução adotada há quase duas décadas pelas indústrias automotivas com a função de aumentar a eficiência na injeção e abaixar as emissões de gases, pois as legislações ambientais ficavam cada vez mais rígidas (BANEY; CHILCOTT; LONG, 1997).

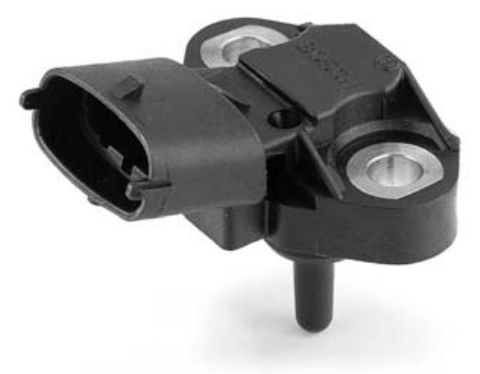

Figura 4 - Sensor MAP.

(Extraído de BOSH, 2010).

A função desse sensor é medir a variação de pressão absoluta no coletor de admissão baseado num material piezoresistivo preso em um diafragma de silício, ou 
seja, com o aumento da depressão no coletor de admissão o diafragma irá se movimentar gerando uma deformação nos piezoresistores, que por sua vez alteram a resistência do seu material gerando uma alteração na tensão de saída. Modelos antigos de sensores do tipo MAP geravam sinais de ondas quadradas que variavam a frequência conforme a depressão aumentava ou diminuía no coletor de admissão, pois tinham o princípio de funcionamento capacitivo. Porém, como a maioria dos sensores do tipo MAP utilizados atualmente tem como princípio de funcionamento um material piezoresistivo, somente serão descritos neste os sensores com esse principio físico.

O conceito fundamental do efeito piezoresistivo é a mudança na resistividade de um material resultando de uma carga aplicada sobre ele. Esse efeito em materiais de silício foi primeiramente descoberto por Smith na década de 50 e foi aplicado na medição de sinais mecânicos por anos. Porém o resultado atingido por Smith não foi tão satisfatório, pois, suas medidas só eram feitas longitudinalmente ou transversalmente no dispositivo a ser medido. Com isso Pfann e sua equipe apresentaram um efeito de piezoresitência diferente do proposto por Smith, conseguindo além das medições longitudinais e transversais, medirem também stress mecânico e torque (CHOU; CHU; LIN, 2009).

Como consequência os sensores de pressão piezoresistivos começaram a ser estudados no início da década de 90. Jaeger construiu um sensor piezoresistivo para medir stress com dispositivos eletrônicos. Kanda criou um processo de fabricação MEMS (Microelectromechanical Systems) para fabricar sensores de pressão piezoresistivos. Posteriormente, várias outras invenções aconteceram sendo uma delas o sensor MAP que é composto de um diafragma de silício com piezoresitores presos nas suas extremidades, e uma das suas principais aplicações hoje em veículos é no coletor de admissão dos mesmos (Figura 5) (CHOU; CHU; LIN, 2009).

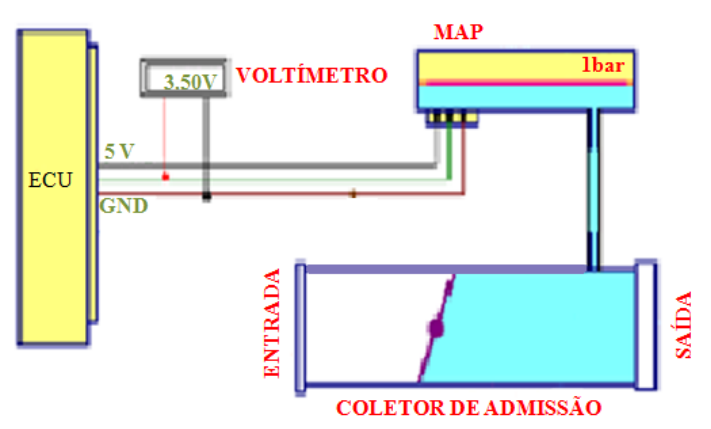

Figura 5 - Sensor MAP no coletor de Admissão com o motor desligado. 
Na figura 5 o motor encontra-se no estado de repouso, ou seja, desligado. Por esse motivo não há uma depressão no coletor de admissão e consequentemente a pressão existente nele é a mesma que a pressão atmosférica (representado em amarelo na figura acima) - 1 bar. Por isso o sensor MAP não está deformado, resultando em uma tensão de saída de aproximadamente três volts e meio (3,5 V).

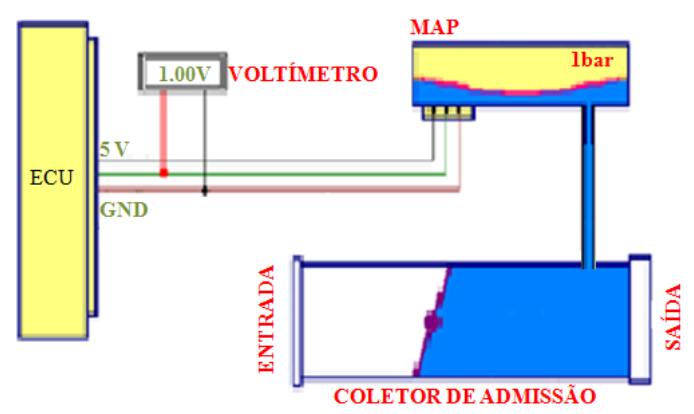

Figura 6 - Sensor MAP no coletor de Admissão com o motor em funcionamento.

No momento em que o motor está em funcionamento e a válvula borboleta se mantém fechada é encontrada a maior depressão no coletor de admissão, ocasionando uma deformação no diafragma do sensor MAP, como pode ser observado na figura 6. Diante dessa deformação há uma alteração no valor da resistência, que por intermédio de um circuito eletrônico (figura 7) altera a tensão de saída para aproximadamente um volt $(1,0 \mathrm{~V})$.

Os valores de tensão mostrados nas figuras 5 e 6 são somente exemplos ilustrativos para uma melhor compreensão, não podendo ser considerado tensões válidas para todos os sensores. Para uma melhor precisão é necessário obter os valores de tensão da curva disponibilizada no data sheet de cada sensor.

\subsubsection{Condicionamento do Sinal}

Um sensor resistivo geralmente não precisa de um condicionamento externo por hardware muito complexo, porém por se tratar de um sinal analógico e por esse sinal entrar em uma das portas de um microcontrolador, ele tem que estar dentro dos prérequisitos do fabricante do controlador para evitar queima de componentes e ainda para que ele seja confiável para o tratamento por software. Por esse motivo é necessário utilizar um hardware para condicionamento.

O circuito eletrônico utilizado na maioria dos condicionamentos de sensores MAP é uma ponte de Wheatstone com um dos resistores da ponte sendo o piezoresistor, 
e com as saídas de tensão conectadas na entrada de um amplificador operacional na configuração comparadora como pode ser notado na figura 7 .

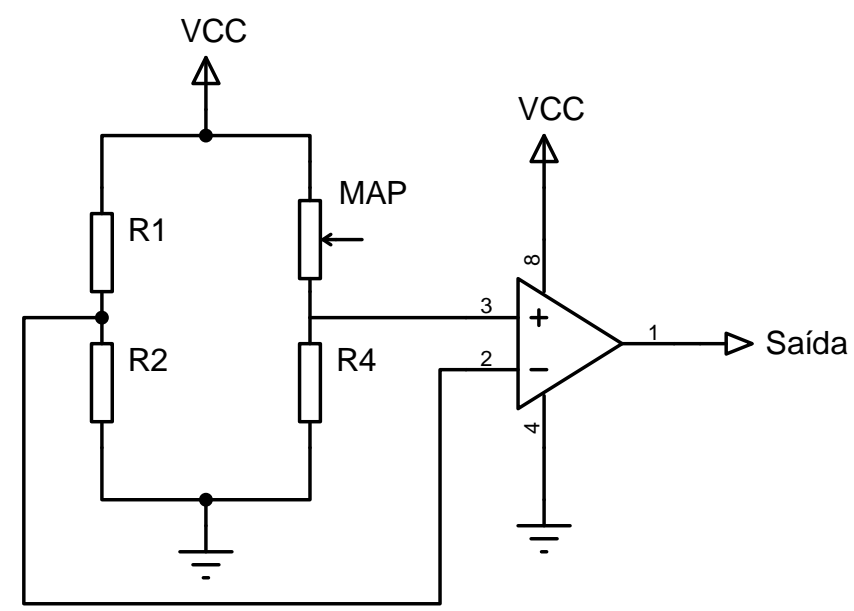

Figura 7 - Circuito eletrônico básico de condicionamento de sinal para o sensor MAP.

Como o sinal de saída do amplificador é limitado em cinco volts (5 V), o circuito grampeador de tensão com diodos pode ser dispensado e esse sinal pode ser inserido diretamente na entrada de um microcontrolador.

Por se tratar de um sensor piezoresistivo a curva de resposta é geralmente linear, como pode ser observado no gráfico da figura 8. Porém, por ser um instrumento que mede a quantidade do fluxo de massa de ar indiretamente, a sua sensibilidade não é muito boa, sendo de $5,3 \mathrm{~kg} / \mathrm{h} / \mathrm{mV}$. Já o tempo de resposta desse sensor é na faixa de $5 \mathrm{~ms}$, o que é considerado aceitável comparando que, com o motor a 6000 rpm o tempo que a válvula de admissão fica aberta é de 5 ms.

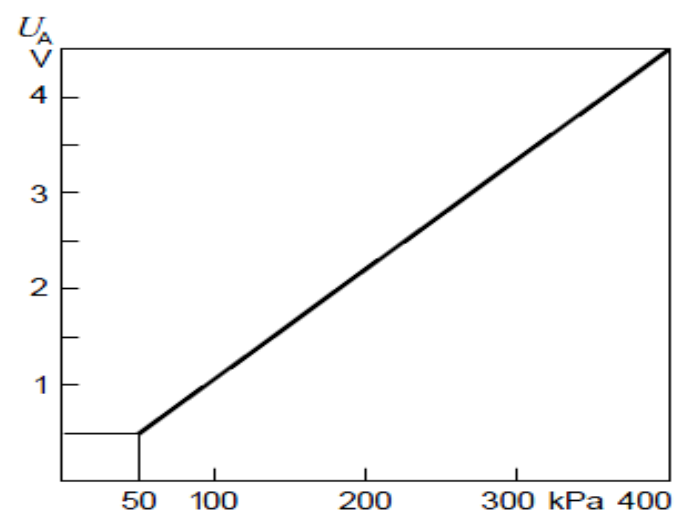

Figura 8 - Curva de Reposta do sensor MAP. (Extraída de BOSH, 2010).

A faixa de trabalho dele é de aproximadamente 0,5 até 4 bar de pressão (50 a $400 \mathrm{KPa}$ ) com a precisão de $2 \%$ na medição de pressão, porém quando convertido para fluxo de ar por intermédio de um microcontrolador, a precisão desse sensor cai para até $8 \%(\mathrm{BOSCH}, 2010)$. 


\subsubsection{Sensor MAF (Manifold Air Flow)}

Como visto anteriormente, a precisão com que se mede a quantidade de massa de ar admitida no interior dos cilindros é de extrema importância para o aumento na eficiência volumétrica do motor além da redução nas emissões de gases e melhoramento na dirigibilidade do veículo. Para isso além do sensor MAP, foram criados sensores que medissem o fluxo de ar diretamente, sem a necessidade de tratamentos prévios por software, assim como o sensor MAF (Figura 9).

Esse sensor tem como princípio físico o mesmo de um sensor de fio ou filme quente, que mede a quantidade do fluxo de massa de ar que passa por ele através do aquecimento ou resfriamento de um fio de platina, cuja variação de temperatura é detectada por um termistor que fica localizado logo após esse fio (Figura 10).

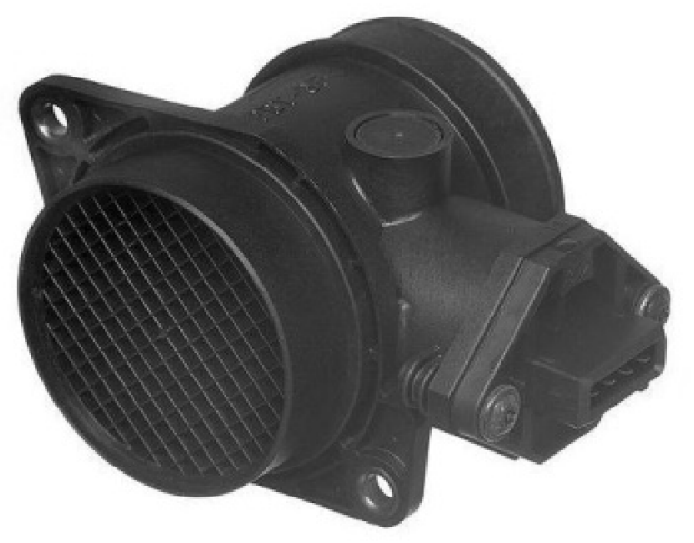

Figura 9 - Sensor MAF.

(Extraído de BOSH, 2010).

O medidor de fluxo de massa com um sensor de fio quente ou filme quente é denominado anemômetro de fio quente. O seu princípio físico é que internamente há um fio/filme de platina que é aquecido eletricamente pela passagem de corrente através dele. Quando esse sensor está localizado em um fluido móvel, parte do aquecimento gerado no fio é transferido por convecção para o fluido passante, que por consequência carrega esse calor até um termistor localizado logo após o fio/filme. Quanto maior a velocidade do fluido maior é a taxa de transferência de calor e a mudança da temperatura do sensor (termistor).

A resistência elétrica desse termistor depende diretamente da temperatura do fluido, portanto uma relação entre o fluxo do fluido e a resistência desse sensor é estabelecida. Uma vez que a temperatura do fio/filme tende a ficar sempre 
constante, aumentando ou diminuindo a corrente que passa por ele de acordo com fluxo do fluido.

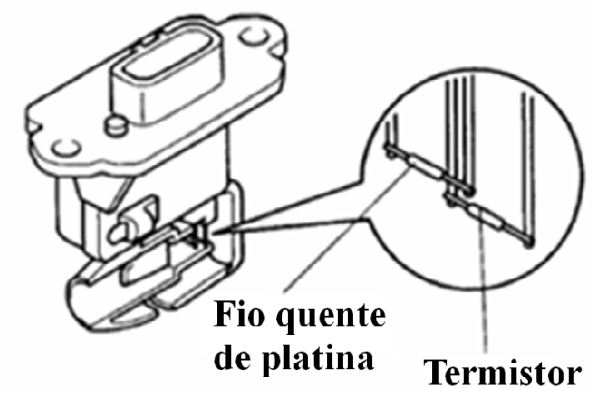

de platina

Termistor

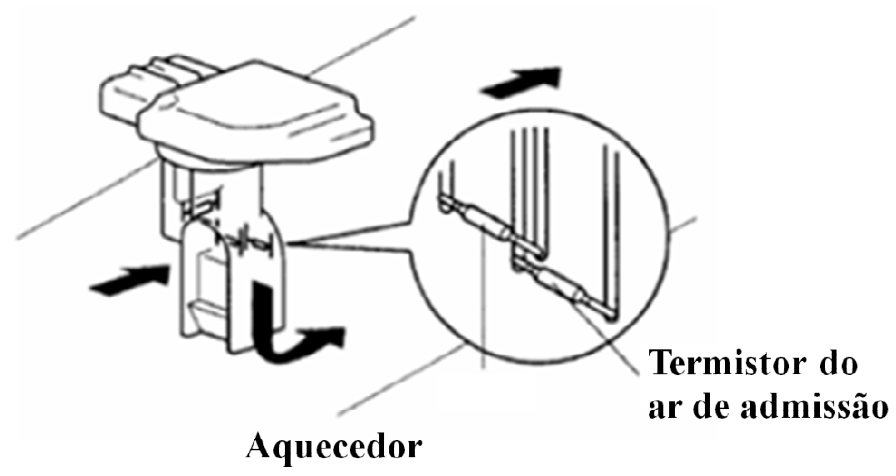

Aquecedor

Figura 10 - Principio físico do sensor de fio quente.

(Extraído de TOYOTA, 2008).

\subsubsection{Condicionamento do Sinal}

O circuito eletrônico utilizado em um sensor MAF é um pouco mais complexo do que o do sensor MAP, devido ao aquecimento do fio e ao sensoriamento da variação desse calor. O funcionamento do circuito pode ser observado na figura 11, onde a resistência $\mathrm{RH}$ é um resistor de aquecimento e conforme a passagem do fluxo de ar se equilibra a uma determinada temperatura com o objetivo de aquecer o filme metálico de platina RS e mantê-lo sempre a uma temperatura constante. RT é um termistor, cuja função é mensurar o calor dissipado de RS. Já os resistores R1, R2, e R3 são resistores de equilíbrio da ponte, que são calibrados no projeto do sensor.

A medida é feita da seguinte forma: com uma intensidade maior do fluxo haverá um resfriamento da resistência $\mathrm{RH}$, que consequentemente ocasionará uma alteração na temperatura do filme metálico RS e consequentemente no termistor RT, que por sua vez desequilibrará a ponte, uma vez que sua resistência é alterada com a diminuição ou o aumento da temperatura.

Com isso haverá uma diferença de potencial entre as saídas da ponte que estão ligadas em um amplificador diferencial. Esse amplificador irá gerar uma tensão de saída quando ocorre essa diferença. Portanto essa tensão gerará uma corrente que atuará na base do transistor fazendo com que ele comece a conduzir. Então uma corrente começa a passar do coletor do transistor para o emissor, onde está localizado o $\mathrm{RH}$ que por sua vez será aquecido por essa corrente até que a ponte entre em equilíbrio novamente. 


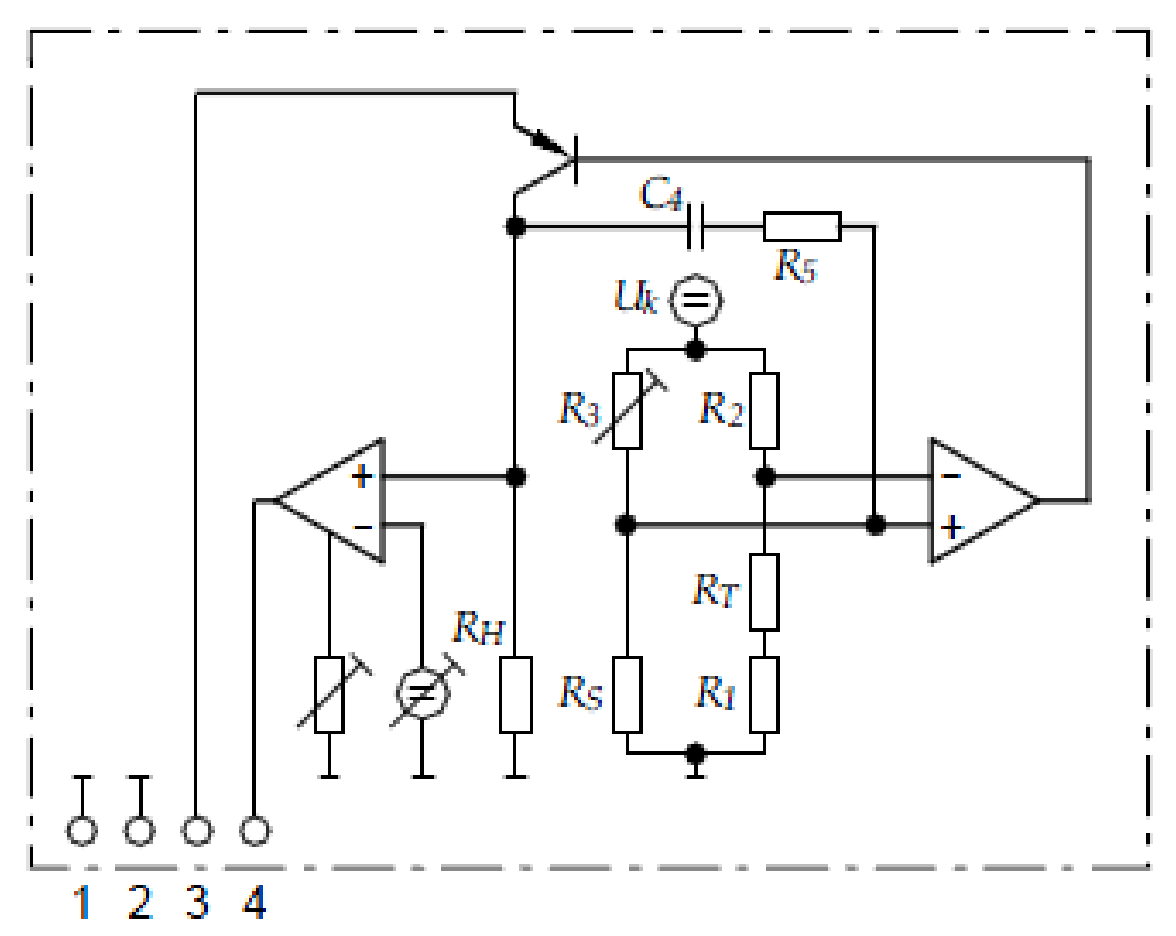

Figura 11 - Circuito eletrônico de condicionamento do sensor MAF.

(Extraído de BOSH, 2010).

Para que esse sensor funcione adequadamente é necessária uma tensão de alimentação positiva no pino três e terra no pino um. Dessa forma o sinal pode ser obtido através do pino quatro, que após o condicionamento tem uma resposta em tensão não linear que varia entre um volt e meio $(1.5 \mathrm{~V})$ à cinco volts $(5 \mathrm{~V})$ em uma função logarítmica. Por isso, o tratamento de software desse sinal é feito apenas por uma tabela criada e gravada na memória do microcontrolador, onde após realizar a leitura do valor em tensão, a mesma é comparada com os valores da tabela $1 \mathrm{e}$ encontra-se então um valor referente ao fluxo de ar admitido.

Por ser o sensor MAF um instrumento que mede a quantidade do fluxo de massa de ar diretamente, a sua sensibilidade é bem melhor que a do sensor MAP, estando na faixa de $0,3 \mathrm{~kg} / \mathrm{h} / \mathrm{mV}$. Porém o tempo de resposta desse sensor é muito alto, pois a resposta da variação da temperatura no termistor é muito lenta, portanto o tempo de resposta é igual ou maior que $30 \mathrm{~ms}$.

Esse é um dos motivos do sensor MAF dificilmente ser utilizado sozinho nos veículos, sem o sinal do MAP para complemento. O range de trabalho dele é de 8 $\mathrm{kg} / \mathrm{h}$ até $1000 \mathrm{~kg} / \mathrm{h}$ e de $-40^{\circ} \mathrm{C}$ à $120^{\circ} \mathrm{C}$ de temperatura. Contudo a precisão dele é bem maior que a do MAP chegando à faixa de $3 \%$. Por isso o MAF é utilizado para refinar os resultados do sensor MAP em veículos preparados (competição) (BOSH, 2010). 
Tabela 1 - Comparação da Tensão com o Fluxo de Ar.

(Extraída de BOSH, 2010).

\begin{tabular}{|c|c|}
\hline Tensão $(\mathbf{V})$ & Massa $(\mathbf{K g})$ \\
\hline 0.115 & 0 \\
\hline 0.7214 & 8 \\
\hline 0.8185 & 10 \\
\hline 1.0185 & 15 \\
\hline 1.4276 & 30 \\
\hline 1.9302 & 60 \\
\hline 2.5817 & 120 \\
\hline 3.4989 & 250 \\
\hline 4.1534 & 370 \\
\hline 4.7298 & 480 \\
\hline
\end{tabular}

\subsubsection{Sensor de Temperatura}

Medições de temperatura em veículos com motores de ciclo Otto são realizadas pela exploração da sensibilidade à variação de temperatura, encontrada na resistência elétrica dos materiais com coeficiente de temperatura positivo (PTC) ou negativo (NTC), como termômetros de contato (BOSH, 2004).

No caso do sensor de temperatura do ar de admissão (IAT - Intake Air Temperature) essa resistência elétrica utilizada é do tipo NTC (Negative Temperature Coefficient), por ser um sensor que tenha uma melhor precisão em baixas temperaturas. Portanto, esse sensor trabalha com os sinais elétricos inversamente proporcionais com a grandeza física temperatura, ou seja, quanto maior for a temperatura menor será a resistência do sensor. Na grande maioria dos veículos esse sensor se encontra encapsulado juntamente com o sensor MAP, como pode ser observado na figura 12 .

Uma resistência NTC geralmente é construída de óxidos de metais. Termistores (termo resistor) de óxidos de metais são formados pela junção de vários óxidos de metais moldados na forma que for desejada e posteriormente são sinterizados a uma temperatura de aproximadamente $1000^{\circ} \mathrm{C}$. Dessa forma, os óxidos formam um material semicondutor cuja resistência varia rapidamente com a variação da temperatura (TRIETLEY, 1986). 


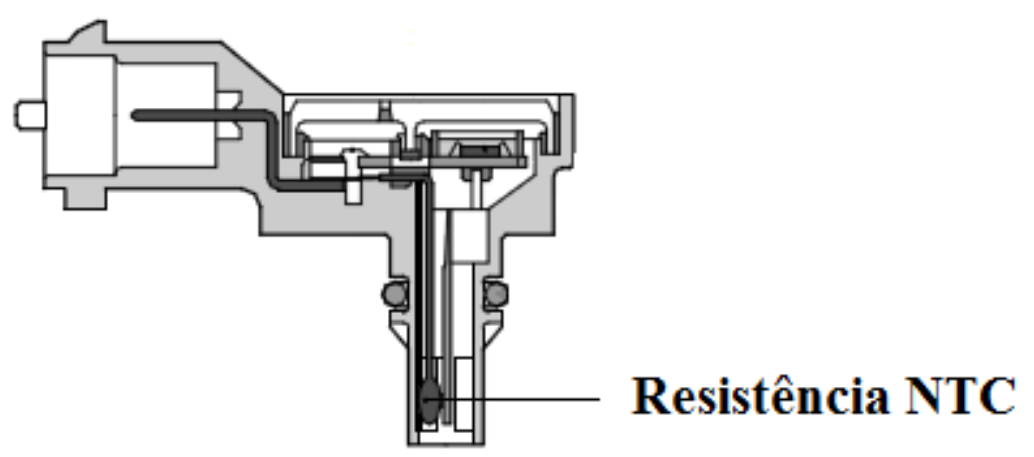

Figura 12 - Resistência NTC em conjunto com o sensor MAP (vista em corte).

(Extraído de BOSH, 2010).

Termistores de coeficiente de temperatura negativo tem como característica: uma faixa curta de medições, alta sensibilidade em baixas temperaturas e por fim uma resposta não linear da variação da resistência em relação a mudanças na temperatura.

\subsubsection{Condicionamento do Sinal}

A conversão da variação de resistência em tensão analógica é predominante desempenhada com a ajuda de resistores neutros de temperatura complementares ou inversamente sensíveis como divisores de tensão. Por se tratar apenas de uma variação de tensão, o circuito eletrônico básico utilizado para tratamento do sinal de saída desse sensor é o mesmo do sensor de pressão MAP (Figura 7).

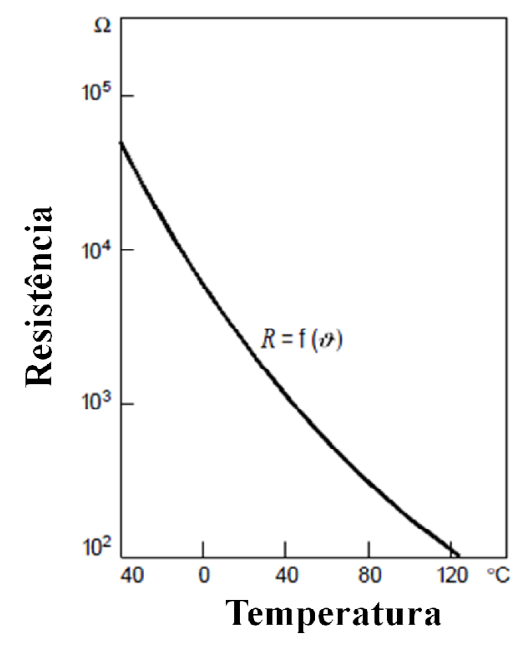

Figura 13 - Curva de resposta do sensor de Temperatura do Ar Admitido.

(Extraída de BOSH, 2010).

Contudo, a curva de resposta desse sensor é bem diferente de um sensor de pressão, onde a curva é praticamente em todo o range, linear. No caso de um 
sensor NTC a curva da variação de resistência através da mudança de temperatura é não linear, como pode ser observado na figura 13.

\subsubsection{Sensor de Rotação}

Existem dois tipos de sensores utilizados que são capazes de identificar a rotação do motor, o tipo Hall e o indutivo (relutância magnética). Ambos têm a finalidade de determinar a rotação instantânea do motor e a posição da árvore de manivelas (VOLKSWAGEN (Brasil), 2009). Porém, para que esses sensores executem uma medição de rotação do motor é necessária à inclusão de mais um componente no motor: a roda geradora de impulsos (roda fônica).

\subsubsection{Roda Geradora de Impulsos}

A roda geradora de impulsos (figura 14) é uma peça mecânica que em muitos motores se assemelham a uma engrenagem. Essa roda é fabricada de um material ferroso, pois precisa excitar o campo magnético dos sensores, como será mais detalhado nas próximas subseções. Além disso, ela é constituída geralmente de 60 dentes com uma falha de dois dentes em uma parte de seu perímetro, resultando em uma roda com 58 dentes e uma falha equivalente a dois. Essa roda é fixada na árvore de manivelas dos motores.

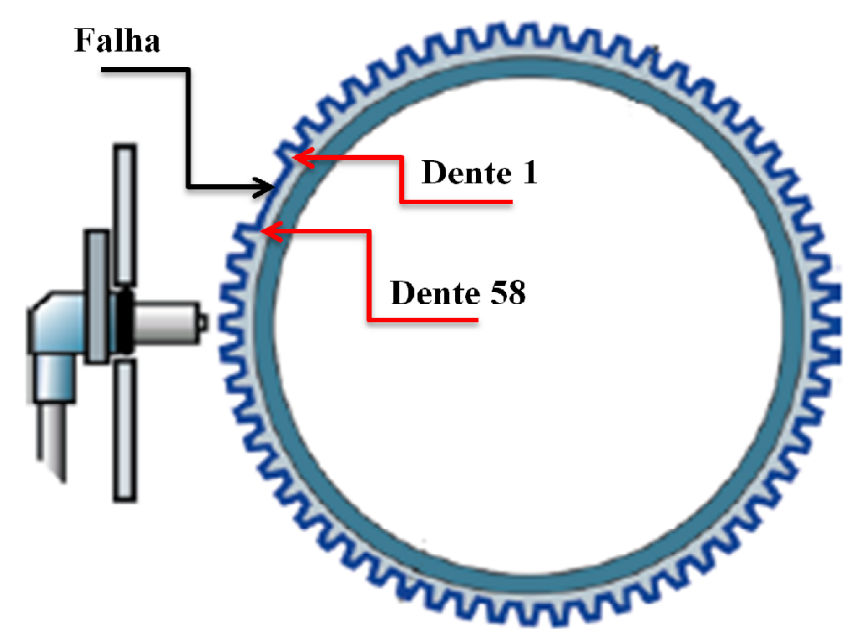

Figura 14 - Roda Geradora de Impulsos.

(Extraída e adaptada de VOLKSWAGEN, 2009). 
Essa falha é necessária para manter o sincronismo do motor, pois através dela a unidade de controle do motor identifica a posição da árvore de manivelas e comanda no momento exato o acionamento das válvulas injetoras e bobina de ignição.

Com a roda geradora de impulsos tendo 60 posições de dentes, a precisão do deslocamento angular da árvore de manivelas é de $6^{\circ}$. Esse valor é calculado através de uma divisão entre $360^{\circ}$ (equivalente a uma volta completa da roda) por 60 (número de dentes da roda). Isso significa que o controle eletrônico do motor consegue identificar precisamente a posição da árvore de manivelas de 6 em 6 graus. Contudo, através de cálculos internos o processador consegue valores ainda mais precisos na movimentação angular da árvore de manivelas.

\subsubsection{Sensor indutivo ou de relutância magnética}

O sensor indutivo consiste em um imã de barra com um pino ferromagnético, sustentando uma bobina de indução com dois terminais. (BOSH, 2004). Por ser um sensor de relutância magnética seu conceito é baseado em um circuito magnético. Um circuito magnético é fechado quando um material magnético o atravessa (ex: ferro, cobalto, níquel, ou um material magnético sintético chamado de ferrite). No caso de um motor do ciclo Otto o material que atravessa o sensor é a roda geradora de impulsos.

A tensão gerada por esse sensor é definida pela intensidade do campo magnético que flui por esse circuito, bem como pela velocidade com que o material magnético atravessa o sensor. Já a intensidade do campo magnético é determinada pela relutância existente no circuito, que é para um circuito magnético em analogia o que a resistência é para um circuito elétrico.

A relutância de um circuito magnético é inversamente proporcional a permeabilidade magnética do material que excita o sensor. Sendo que, a permeabilidade do ferro é bem menor que a do ar, é possível dizer que quando o material ferroso inicia a passagem pelo sensor é gerado um campo magnético, que atinge seu ponto máximo aproximadamente na metade de um dente da roda geradora de impulsos.

Ao ser gerado um campo magnético, a bobina enrolada no pino ferromagnético é induzida e uma tensão aparece entre os dois fios de saída da mesma, atingindo a 
tensão máxima no mesmo ponto onde o campo magnético atingiu. Quando o dente está totalmente alinhado com sensor a tensão é nula, se elevando com o afastamento do dente para o outro lado do pólo. Isso resulta em uma inversão no sentido da corrente, gerando uma tensão "negativa", que atingirá o ponto máximo também aproximadamente na metade do dente, alcançando zero volt novamente quando o sensor estiver isento de material magnético através dele, ou seja, apenas ar está preenchendo a folga entre o sensor e a roda geradora de impulsos (Figura 15) (Ribbens, 1998). Portanto, o sinal de tensão de saída de um sensor do tipo indutivo é praticamente um sinal senoidal que varia sua amplitude e frequência de acordo com a rotação do motor.

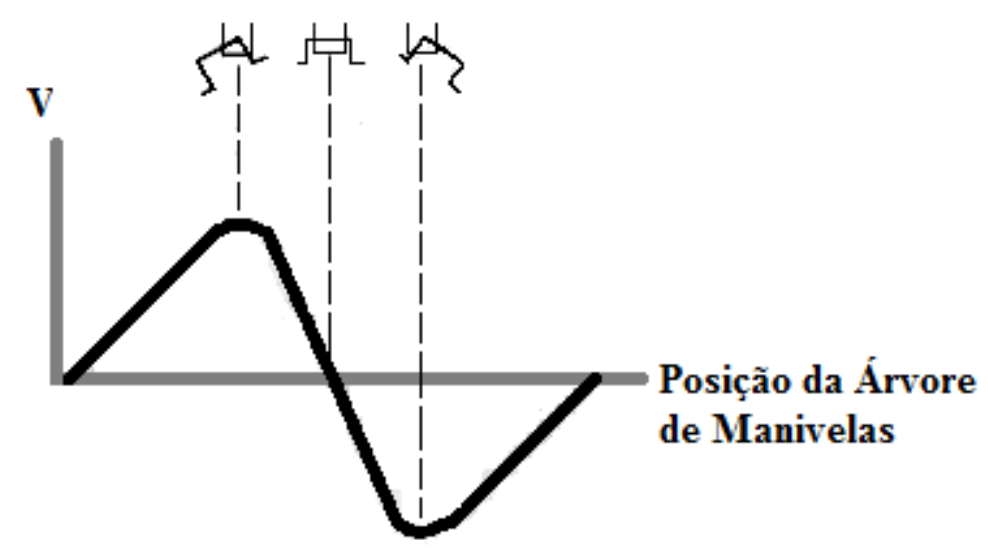

Figura 15 - Sinal de tensão de saída de um sensor indutivo.

O condicionamento desse sinal é mais bem descrito no capítulo três onde a metodologia desse trabalho é descrita, abordando a confecção do hardware e software. Contudo é importante mencionar aqui uma característica desse sensor.

O sensor de relutância magnética é um sensor que gera uma tensão através de um imã e um material ferroso como visto acima. Com isso, é possível observar que esse sensor não necessita de alimentação de tensão para funcionar, sendo dessa forma considerado um sensor passivo.

\subsubsection{Sensor de efeito hall}

O efeito Hall foi descoberto por Dr. Edwin Hall em 1879 enquanto ele estava se candidatando ao programa de doutorado da Universidade de Hopkins em Baltimore. Ele descobriu que se um campo magnético fosse aplicado perpendicularmente ao fluxo de corrente em um material (elemento hall), uma diferença de potencial 
aparecia nos lados opostos. Observando também que essa tensão era proporcional ao fluxo de corrente ou da indução magnética do condutor (Honeywell, 2002).

Esse elemento hall é um pequeno material semicondutor que quando não excitado por um campo magnético sua tensão de saída é igual à zero (Figura 16a). Porém quando uma corrente passa através desse elemento por meio de um circuito externo, uma tensão surge nesse elemento perpendicular à direção do fluxo de corrente e perpendicular à direção do fluxo magnético que por sua vez também é aplicado perpendicularmente à direção do fluxo de corrente. Esse fenômeno físico é chamado de Efeito Hall. E sua explicação se deve a uma força chamada de Lorentz. Essa força age nos elétrons que se movimentam no elemento hall a partir do momento em que um fluxo de campo magnético é aplicado perpendicular ao fluxo de corrente do mesmo (Ribbens, 1998).

Quando isso acontece, a força de Lorentz age sobre os elétrons, sendo que a intensidade dessa força depende da velocidade dos elétrons e da intensidade do campo magnético, e os elétrons acabam mudando a trajetória de sua direção e se movem para o lado inferior do elemento hall, criando dessa forma uma diferença de potencial entre o lado superior (positivo) e o lado inferior que por estar com mais elétrons se torna um potencial negativo. Dessa forma, é possível observar então uma tensão nos lados opostos da aplicação da corrente (Figura 16b) (Ribbens, 1998).

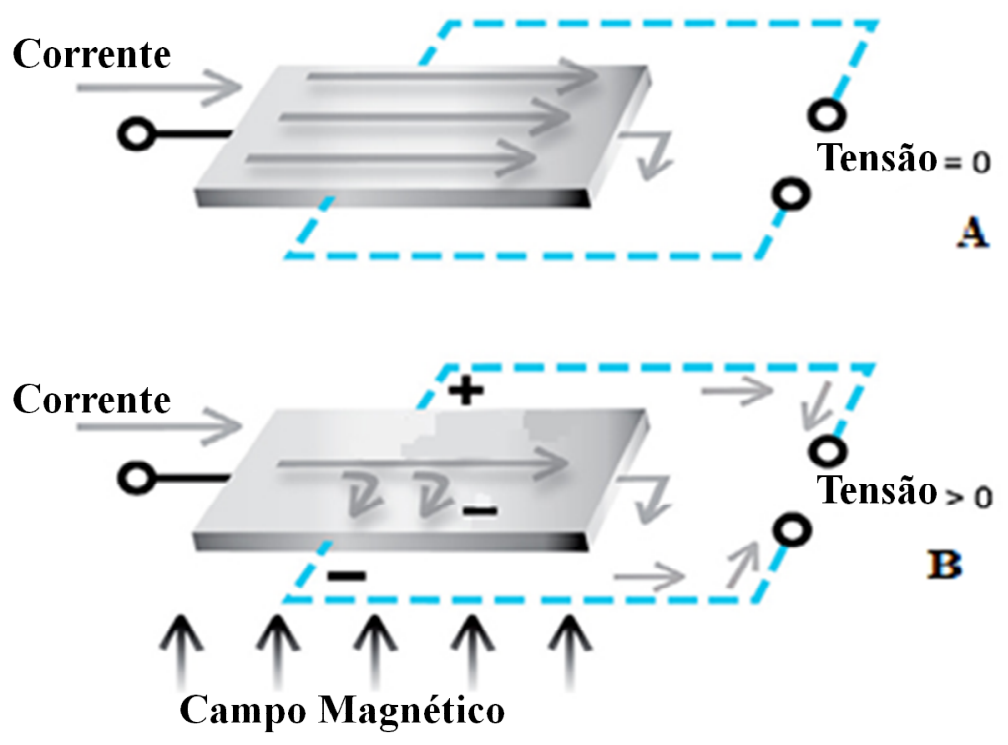

Figura 16 - A) Elemento hall sem aplicação de campo magnético. B) Elemento hall com aplicação de campo magnético.

Como mostra a figura 17, o $\mathrm{Cl}$ (Circuito Integrado) Hall, com tecnologia bipolar para temperaturas sustentadas até $150^{\circ} \mathrm{C}$ e conexão direta com o sistema elétrico do veículo, fica dentro de um circuito magnético quase completamente isolado, 
consistindo em elementos polares e magnéticos permanentes. Um volante de disparador ferromagnético (roda geradora de impulsos) se desloca pelo entreferro. $O$ dente do volante disparador interrompe o fluxo magnético (ou seja, move-o para além do sensor), enquanto o espaço no volante disparador permite-lhe deslocar pelo sensor desimpedido (BOSCH, 2004).

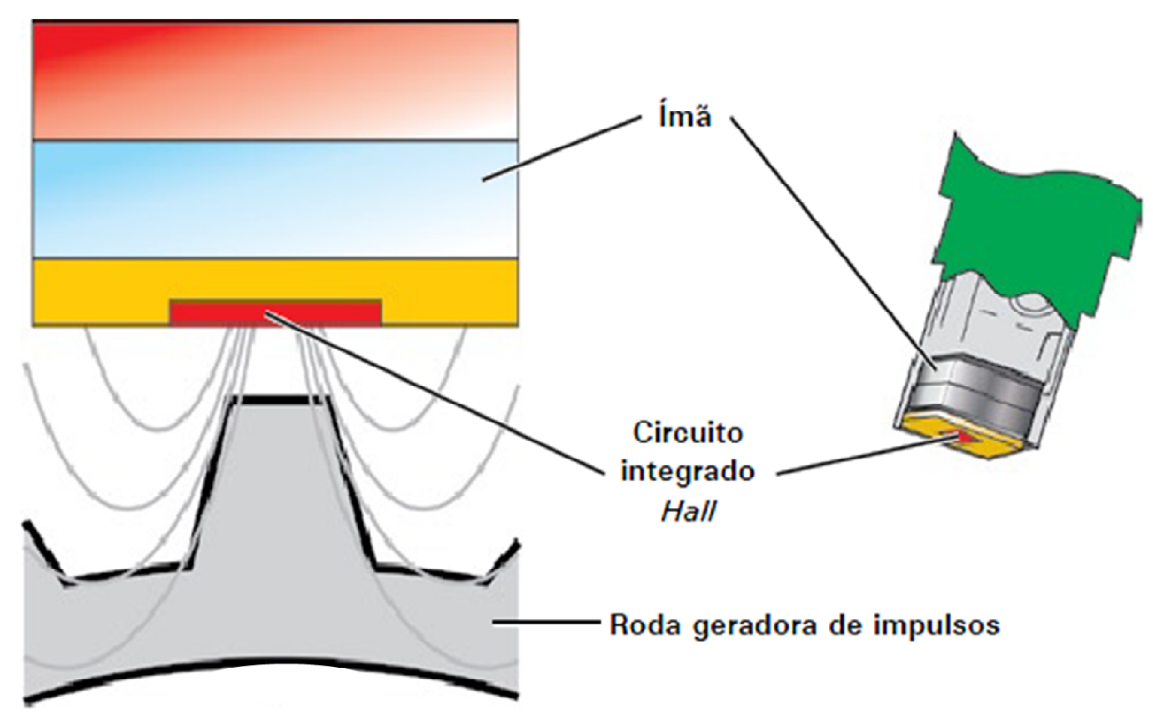

Figura 17 - Circuito Integrado Hall do sensor de rotação.

(Extraído de VOLKSWAGEN (Brasil), 2009).

Condicionamento de Sinal

A tensão gerada por esse sensor é definida pela intensidade do campo magnético e pela intensidade de corrente que flui pelo elemento hall. Porém por mais que essas duas grandezas sejam relativamente grandes, a tensão na saída sempre será muito pequena, em ordem de miliVolts. Com isso é necessário um circuito de amplificação desse sinal para que a unidade de controle do motor consiga captar e processá-lo posteriormente.

Portanto, o circuito eletrônico utilizado para condicionar o sinal do sensor hall é o apresentado na figura 18 e descrito a seguir.

Nesse circuito assim como nos outros apresentados nesse trabalho, é utilizado um regulador de tensão (será detalhado no capítulo 3) para gerar uma tensão estabilizada para o elemento hall e com isso gerar a corrente de trabalho que o atravessa. Para condicionar o sinal de saída foi usado um amplificador operacional na configuração comparadora que amplificará o sinal na saída do mesmo. 


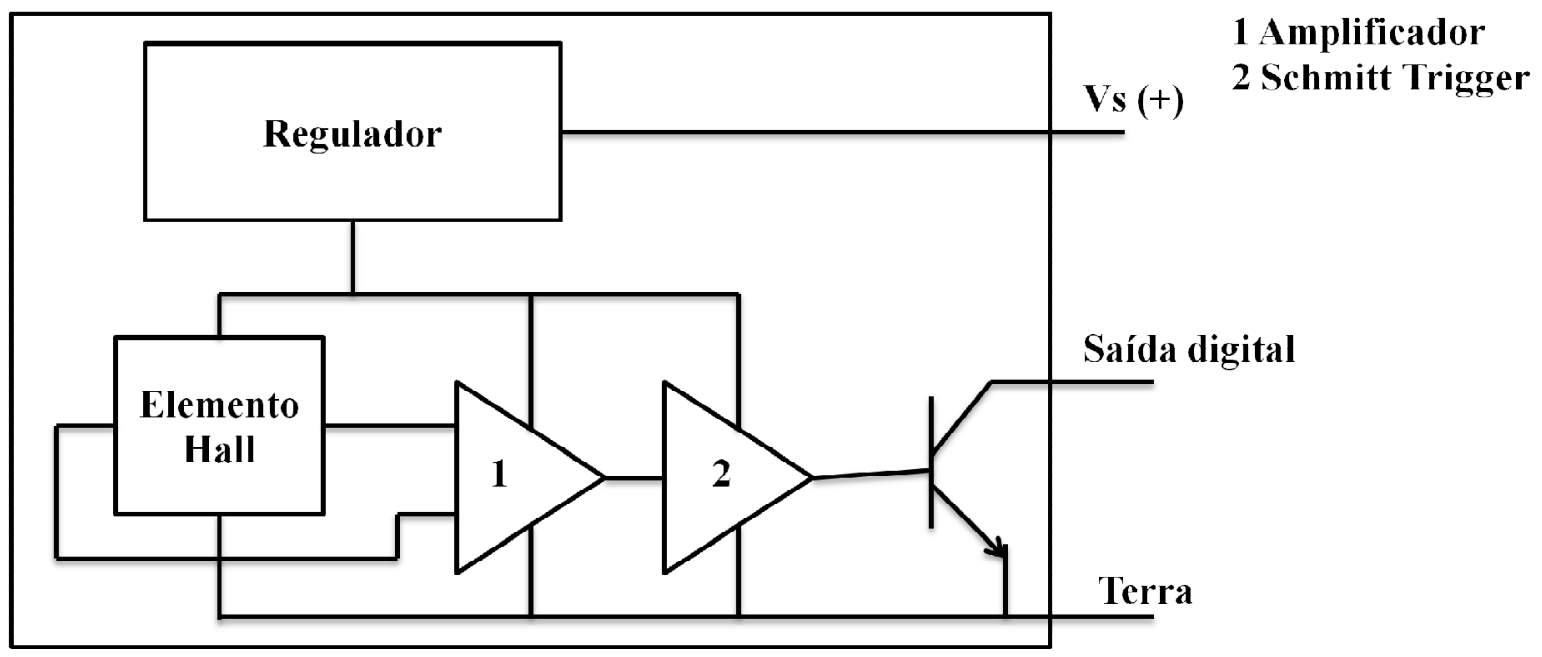

Figura 18 - Circuito eletrônico de condicionamento do sinal do sensor Hall.

(Extraído e adaptado de TRIETLEY, 1986).

Até esse ponto a tensão gerada é analógica. Contudo, para um melhor processamento posterior pela ECU, esse sinal é transformado em um sinal digital através de um schmitt trigger em conjunto com um transistor NPN trabalhando em modo de saturação ou corte. Dessa forma o sinal de onda obtido na saída do condicionador é um sinal digital conforme observado na figura 19.

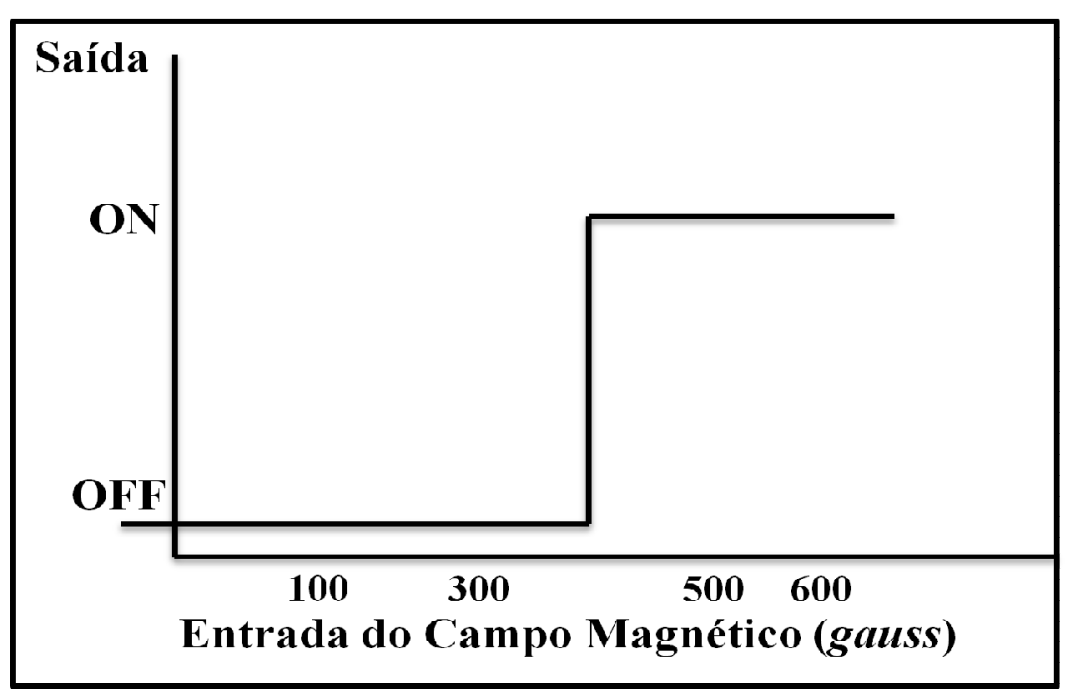

Figura 19 - Sinal de saída do condicionador de sinal do sensor Hall. (Extraída e adaptada de TRIETLEY, 1986).

\subsubsection{Sensor de Posição da Válvula Borboleta}

O sensor de posição da válvula borboleta TPS (Throttle Position Sensor) é usado para indicar o ângulo de abertura da válvula borboleta e geralmente é fabricado de um potenciômetro resistivo de filme espesso (Figura 20). Ele responde ao 
movimento de rotação do eixo da válvula (antigamente esse movimento era feito através de cabos diretamente do pedal do acelerador e hoje é executado através de um motor DC comandado pela ECU). O TPS fornece o feedback para o fechamento da malha de controle da ETC (Electronic Throttle Control) Air Control Valve (válvula de controle de ar) (DELPHI, 2003).

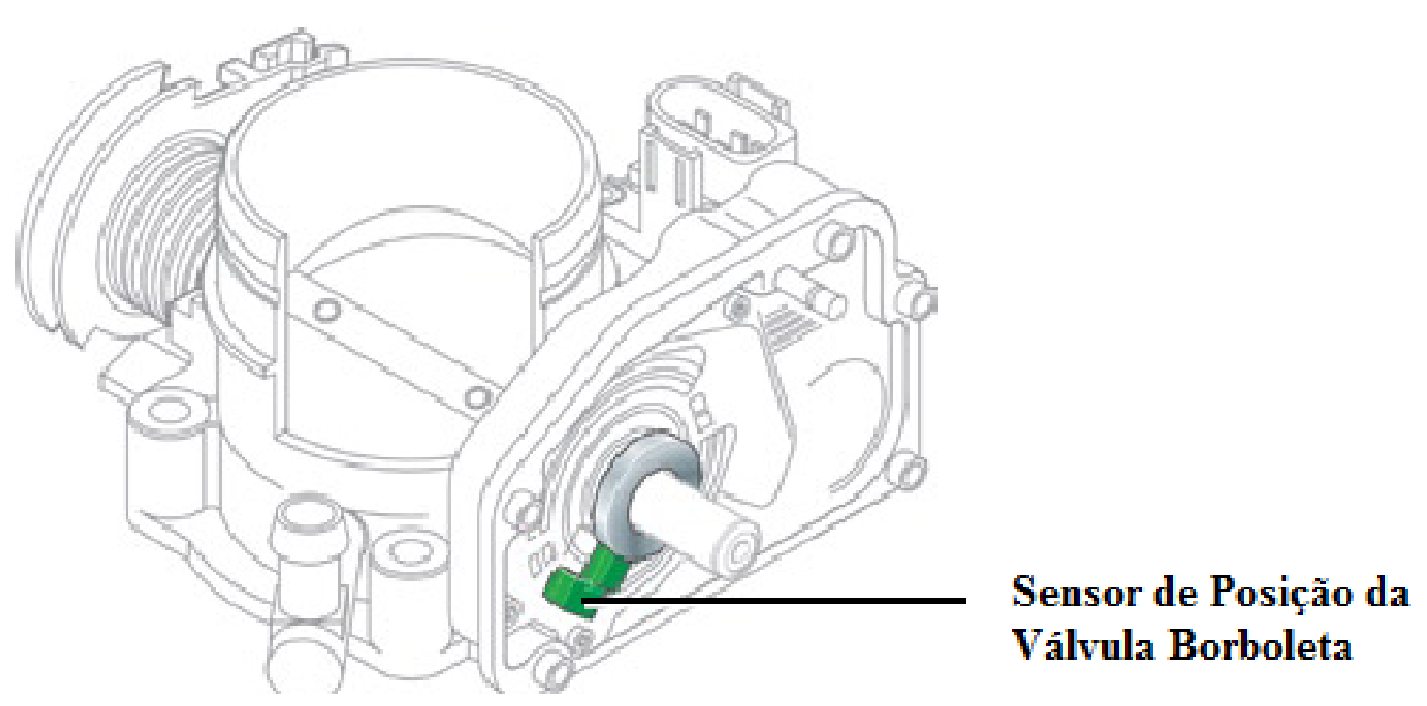

Figura 20 - Corpo de Borboleta com destaque no sensor de posição.

(VOLKSWAGEN (BRASIL), 2009).

A maioria dos sensores de posição da válvula borboleta são essencialmente potenciômetros. Uma ponta do resistor é conectada à terra e na outra é fixada uma tensão "V" (ex: 5 volts). A tensão no pino de contato é proporcional ao ângulo formado entre o pino terra e o contato móvel (RIBBENS, 1998).

Segundo a Delphi (2003) para a ETC Air Control Valve, dois sensores de posição são utilizados. Os dois sensores usam curvas de respostas opostas. Um sinal aumenta enquanto o outro sinal diminui com a variação rotacional da válvula borboleta. O uso de dois sensores habilita a capacidade de diagnóstico do sistema, que pode reduzir o efeito de algumas falhas indesejadas. Se algum dos dois sinais de TPS ficar comprometido, o sistema ETC pode detectar que esse sinal está danificado (identificando uma discrepância com o outro sinal) e com isso toma ações apropriadas, com o intuito de tentar controlá-la mesmo com um sinal avariado.

Como o sinal de saída desse sensor é um sinal analógico, varia a tensão proporcionalmente a variação angular da válvula borboleta. $\mathrm{O}$ condicionamento do sinal desse sensor será abordado no próximo capítulo juntamente com o tratamento dos sinais analógicos na subseção de hardware. 


\subsubsection{Equações realizadas para determinar a quantidade de ar admitida}

O gerenciamento eletrônico do motor utiliza dos sinais dos sensores descritos nas subsecções anteriores para calcular a exata quantidade de massa de ar admitida pelos cilindros e posteriormente o volume de combustível que deve ser injetado. Para isso é utilizada uma estratégia conhecida como speed $x$ density (velocidade $x$ densidade).

Essa estratégia utiliza os sinais dos sensores de temperatura e pressão do ar admitido para calcular a densidade do ar (eq. 1), e do sensor de posição da válvula borboleta para determinar a área (eq. 3) livre à passagem do ar, e com isso determinar a vazão da válvula borboleta.

$$
\rho=\eta * \frac{\mathrm{P}}{\mathrm{R} * \mathrm{~T}}
$$

Na eq. $1, \rho$ significa densidade, $\eta$ significa massa molar (MM), que no caso como está sendo calculada a densidade do ar é utilizada uma massa molar aproximada de $29 \mathrm{~g} / \mathrm{mol}, \mathrm{R}$ é o valor da constante geral dos gases $\left(0,082 \frac{\mathrm{atm} * 1}{\mathrm{~K} * \mathrm{~mol}}\right.$ ou $\left.62,3 \frac{\mathrm{mmHG} * 1}{\mathrm{~K} * \mathrm{~mol}}\right)$, T é o valor de temperatura absoluta do ar (graus Kelvin) e P é o valor de pressão em atm ou $\mathrm{mmHG}$.

A densidade do ar é extremamente importante no cálculo da massa de ar, pois quanto mais denso está o ar, mais moléculas de oxigênio há dentro da câmara de combustão. Como o oxigênio é um comburente essencial para a combustão, quanto mais oxigênio for admitido, mais combustível pode ser injetado, obtendo uma resultante de força maior na combustão.

Com a densidade do ar calculada é possível determinar o quanto de massa de ar será admitida em cada cilindro através da eq. 2 descrita a seguir:

$$
\text { Massa de } \mathrm{Ar}=\rho * \frac{\text { Cilindrada }}{\mathrm{n}}
$$

Multiplicando a densidade do ar pela cilindrada do motor (capacidade volumétrica) e dividindo pela quantidade de cilindros (n) que esse motor possui é encontrada a massa de ar admitida individualmente por cilindro. Esse resultado é utilizado para determinar qual será a massa de combustível que deverá ser injetada dentro de cada cilindro, e com isso calcular o tempo que a ECU terá que atuar em cada válvula injetora. 
O valor de cilindrada pode ser obtido com a somatória do volume de cada cilindro do motor.

Para completar o sensoriamento e estimar uma quantidade de massa de ar admitida mais precisa, a vazão da válvula borboleta pode ser calculada em função da área de abertura da mesma. Segundo a Delphi (2003) a área da válvula borboleta pode ser calculada utilizando-se da eq. 3 como é descrito a seguir:

$$
\frac{4 A_{t h}}{\pi D^{2}}=\left(1-\frac{\cos \psi}{\cos \psi_{0}}\right) \frac{2}{\pi}\left[\frac{a}{\cos \psi}\left(\cos ^{2} \psi-a^{2} * \cos ^{2} \psi_{0}\right)^{1 / 2}+\frac{\cos \psi}{\cos \psi_{0}} \sin ^{-1}\left(\frac{a \cos \psi_{0}}{\cos \psi}\right)-a\left(1-a^{2}\right)^{1 / 2} \sin ^{-1} a\right]
$$

Onde $A_{\text {th }}$ é a área de abertura da válvula borboleta, "D" é o diâmetro do corpo da válvula borboleta, "d" é o diâmetro da válvula borboleta, "a" é a razão de "d" por "D", $\psi_{0}$ é o ângulo da válvula borboleta quando fechada e $\psi$ é o ângulo de abertura da válvula borboleta.

Calculando essa área é possível determinar a vazão momentânea da válvula borboleta e com isso estimar para cada rotação se a abertura da válvula borboleta está sendo suficiente para realizar o enchimento completo dos cilindros. Porém esse cálculo não é realizado internamente em um microcontrolador, pois devido a sua complexidade o tempo de processamento para executa-lo seria consideravelmente grande. Por isso, as estimativas de quantidade de massa de ar admitida na maioria dos casos são realizadas somente com as eq. 1 e 2 . Sendo a posição da válvula borboleta utilizada somente como um fator de correção.

\subsection{SISTEMA DE ALIMENTAÇÃO DE COMBUSTíVEL}

O objetivo básico de um sistema de injeção de combustível em motores de combustão interna é dosar a quantidade de ar que entra no interior dos cilindros com o objetivo de predefinir a mistura de ar e combustível (A/C) necessária para o funcionamento ideal do motor.

Historicamente, dois tipos de dosagem de combustível fizeram sucesso ao ser empregados em motores do ciclo Otto: os carburadores, baseado na sucção do combustível e os sistemas de injeção eletrônica, baseados no controle eletrônico da injeção de combustível (GONZÁLEZ, 2007).

Os sistemas carburados são puramente mecânicos, tendo como componentes principais uma cuba, na qual o combustível é armazenado; um tubo de Venturi, que 
consiste de um estreitamento na tubulação de admissão de ar; e um furo calibrado, denominado giclê, que conecta a cuba ao tubo de Venturi.

Os carburadores têm um funcionamento muito complexo e de difícil entendimento, e não é o foco deste trabalho. Uma breve explicação pode ser feita da seguinte maneira: o carburador trabalha através do diferencial de pressão entre a cuba e o tubo de Venturi. Pode-se constatar isso, uma vez que ao pisar no pedal do acelerador a válvula borboleta é aberta, aumentando o fluxo de ar admitido, com isso há uma passagem maior de ar através do tubo de Venturi que faz com que a pressão dentro dele seja menor do que a pressão na cuba onde está armazenado o combustível. Neste caso, devido às leis da física, o combustível da cuba é succionado através de um tubo calibrado (giclê) e despejado no coletor de admissão, onde é feita a mistura com o ar para posteriormente entrar nos cilindros. Esse é o funcionamento ideal do carburador para um motor que está sendo acelerado, porém quando o motor está em marcha lenta o funcionamento é diferente (GONZÁLEZ, 2007).

No estado de marcha lenta existem dois ajustes básicos no carburador para 0 funcionamento ideal do motor: o primeiro é o de fechamento da válvula borboleta, fazendo com que ela permaneça aberta apenas o suficiente para fornecer o fluxo de ar necessário para alimentar os cilindros; e o segundo é o ajuste de um parafuso (chamado de parafuso de marcha lenta) localizado próximo da aresta da válvula borboleta, tendo a função de dosar o combustível necessário para uma combustão ideal através de um orifício ligado na cuba (SILVIO, 2000).

O carburador foi utilizado durante muito tempo com sucesso, porém as leis ambientais de emissões de gases fizeram com que gradativamente os carburadores fossem descontinuados abrindo lugar aos sistemas de injeção eletrônica.

As leis ambientais não foram às únicas que fizeram os carros substituírem o carburador pelo sistema de injeção eletrônica. Vantagens como melhor rendimento do motor, menor consumo de combustível, maior confiabilidade, facilidade na manutenção, partidas mais fáceis, entre outras também foram fatores importantes para desenvolvimentos nessa área.

Com isso os primeiros sistemas eletrônicos de injeção surgiram entre as décadas de 50 e 70 nos principais e mais luxuosos carros da época, como os De Soto's em 1958 (MATTAR, 2005). Porém os carburadores somente foram substituídos totalmente entre o final dos anos 80 e o começo dos anos 90, quando as leis ambientais 
estavam tão rígidas que os carburadores não conseguiram mais atendê-las (GONZÁLEZ, 2007).

A partir de então, o sistema de injeção eletrônica foi incluído como item de série para praticamente todos os veículos fabricados no mundo, sofrendo modificações e melhoramentos com o passar do tempo.

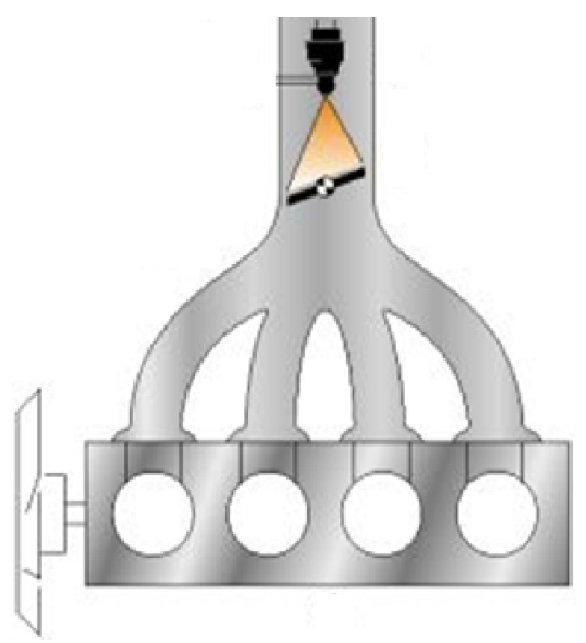

Figura 21 - llustração de um sistema de injeção eletrônica monoponto. <Extraído e adaptado de (W.J, 2013)>.

Assim foram criados dois métodos de injeção eletrônica: o monoponto (Figura 21) e o multiponto (Figura 22). No sistema monoponto o veículo está equipado com apenas uma válvula injetora localizada no coletor de admissão antes da válvula borboleta, e é ela que pratica a injeção para os quatro cilindros do motor. Já o sistema multiponto, é um pouco mais complexo, porém com uma eficiência, qualidade e economia muito maior que o monoponto. Nesse sistema o motor contempla quatro válvulas injetoras - uma para cada cilindro - sendo que o acionamento de cada uma acontece no ciclo de admissão do cilindro respectivo.

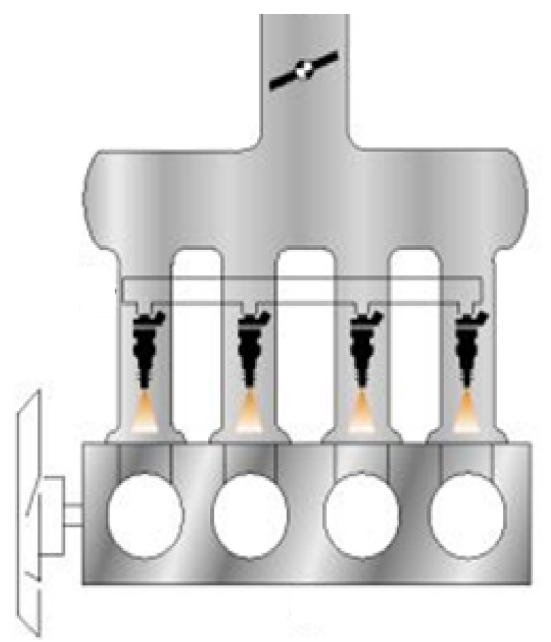

Figura 22 - llustração de um sistema de injeção eletrônica Multiponto. <Extraído e adaptado de (W.J, 2013)>. 
Todos os sistemas citados até agora são de injeção indireta, pois executam a injeção no coletor de admissão, lado de fora dos cilindros, porém atualmente existem sistemas que fazem essa injeção diretamente nos cilindros, conhecidos como: injeção direta. Contudo, esses sistemas não serão abordados neste trabalho, pois o objetivo dele é construir uma unidade de gerenciamento eletrônico para controlar um motor a combustão interna que possui uma injeção de combustível indireta.

\subsection{FORMAÇÃO DA MISTURA AR/COMBUSTÍVEL (A/C)}

Antes do último pré-requisito da combustão ser dissertado (o calor) é importante entender como a mistura ar/combustível admitida no interior dos cilindros é formada.

Primeiramente é importante lembrar-se dos dois pré-requisitos anteriores: a admissão de ar e o sistema de combustível. O primeiro responsável por admitir a quantidade de ar necessária para o funcionamento ideal do motor e o segundo responsável por injetar a quantidade de combustível necessária para que haja uma mistura homogenia entre o ar admitido e o combustível injetado.

Portanto, é extremamente importante que esses dois pré-requisitos trabalhem em conjunto e principalmente em sincronismo. Para que essa mistura seja considerada ideal (estequiométrica) é necessário que o oxigênio presente na massa de ar admitida seja suficiente para reagir completamente com a massa de combustível injetada, obtendo-se como produtos dessa reação de combustão: o Dióxido de Carbono $\left(\mathrm{CO}_{2}\right)$, a Água $\left(\mathrm{H}_{2} \mathrm{O}\right)$ e os gases inertes presentes no ar (basicamente o nitrogênio e alguns outros gases presentes no ar atmosférico que não reagem no processo de combustão). (PUJATTI 2007)

Segundo Pujatti (2007) a relação ar/combustível estequiométrica $(A / C(s))$ varia de acordo com o tipo de combustível utilizado, como mostra a tabela 2, tendo sempre como referência a concentração de $\mathrm{O}_{2}$ presente no ar atmosférico.

Em função do combustível utilizado e da quantidade de massa de ar admitida, é possível determinar a quantidade de massa de combustível ideal necessária para a formação de uma mistura A/C homogenia, possibilitando o funcionamento do motor na melhor condição de operação para o regime que o mesmo se encontra. Essa massa de combustível é determinada pela eq. 4 . 
Tabela 2 - Relação A/C estequiométrica em função do combustível (Pujatti 2007).

\begin{tabular}{|c|c|}
\hline Combustível & A/C $[\mathrm{Kg} / \mathbf{K g}]$ \\
\hline Gasolina Pura (E0) & $14,7: 1$ \\
\hline Etanol (E100) & $9,0: 1$ \\
\hline Gasolina Comum (E22) & $13,2: 1$ \\
\hline Diesel & $15,2: 1$ \\
\hline Metanol & $6,4: 1$ \\
\hline Metano & $17,2: 1$ \\
\hline Propano $\left(\mathrm{C}_{3} \mathrm{H}_{8}\right)$ & $15,6: 1$ \\
\hline Butano $\left(\mathrm{C}_{4} \mathrm{H}_{10}\right)$ & $15,4: 1$ \\
\hline Hidrogênio & $34,0: 1$ \\
\hline
\end{tabular}

$$
\text { Massa combustível }=\frac{\text { Massa de ar }}{\text { Relação estequiométrica }} * \lambda
$$

Desta forma, é determinada de uma maneira simples e direta a quantidade de massa de combustível que deve ser injetada para dentro dos cilindros, onde é necessário apenas as variáveis: massa de ar admitida, relação estequiométrica do combustível (Tabela 2) e por fim um fator de retroalimentação fornecido por um sensor de oxigênio chamado de fator lambda. O cálculo desse fator de correção pode ser observado na eq. 5 .

$$
\lambda=\frac{\text { A/ Creal }}{\text { A/ C ideal }}
$$

Os valores do fator $\lambda$ representam a condição em que se encontra a mistura $A / C$, ou seja, se a mistura está estequiométrica, $\lambda=1$, se a mistura está com excesso de oxigênio (mistura pobre), $\lambda>1$, e ainda se a mistura está com excesso de combustível (mistura rica), $\lambda<1$. Por isso esse fator influência também diretamente no cálculo da massa de combustível que deve ser injetada pelo sistema de injeção.

Enfim, o gerenciamento eletrônico do motor deve calcular o tempo em que a válvula injetora permanecerá aberta para fornecer a quantidade mássica de combustível calculada. Para isso é utilizada a eq. 6. Onde é dividida a massa de combustível calculada pela vazão do injetor, determinando assim o tempo básico de injeção, que posteriormente é corrigido por outras variáveis e estratégias do motor para cada regime de operação.

$$
\text { Tempo de injeção }=\frac{\text { Massa de }}{\text { do injetor }}
$$




\subsubsection{Emissões de Gases de Escape de um Motor Ciclo Otto}

Segundo Milhor (2002), a exaustão do motor de combustão interna ciclo Otto consiste dos produtos da combustão da mistura ar-combustível. No Brasil, o gasool (mistura de gasolina e álcool anidro) e o álcool hidratado ( $96 \%$ etanol e $4 \%$ água) são os combustíveis mais utilizados nos veículos com motores de ciclo Otto.

De acordo com a equação química que explica a combustão, a queima de um combustível junto com o ar, na teoria deveria ser perfeita, pois somente restaria nitrogênio, água e dióxido de carbono (VOLKSWAGEN (BRASIL), 2009).

Na prática, devido às influências de efeitos químicos, físicos e elétricos dentro da câmara de combustão, essa queima total do combustível não acontece, e no resíduo da combustão aparecem os gases poluentes e nocivos para o meio ambiente, como pode ser observado pela figura 23 (VOLKSWAGEN (BRASIL), 2009).

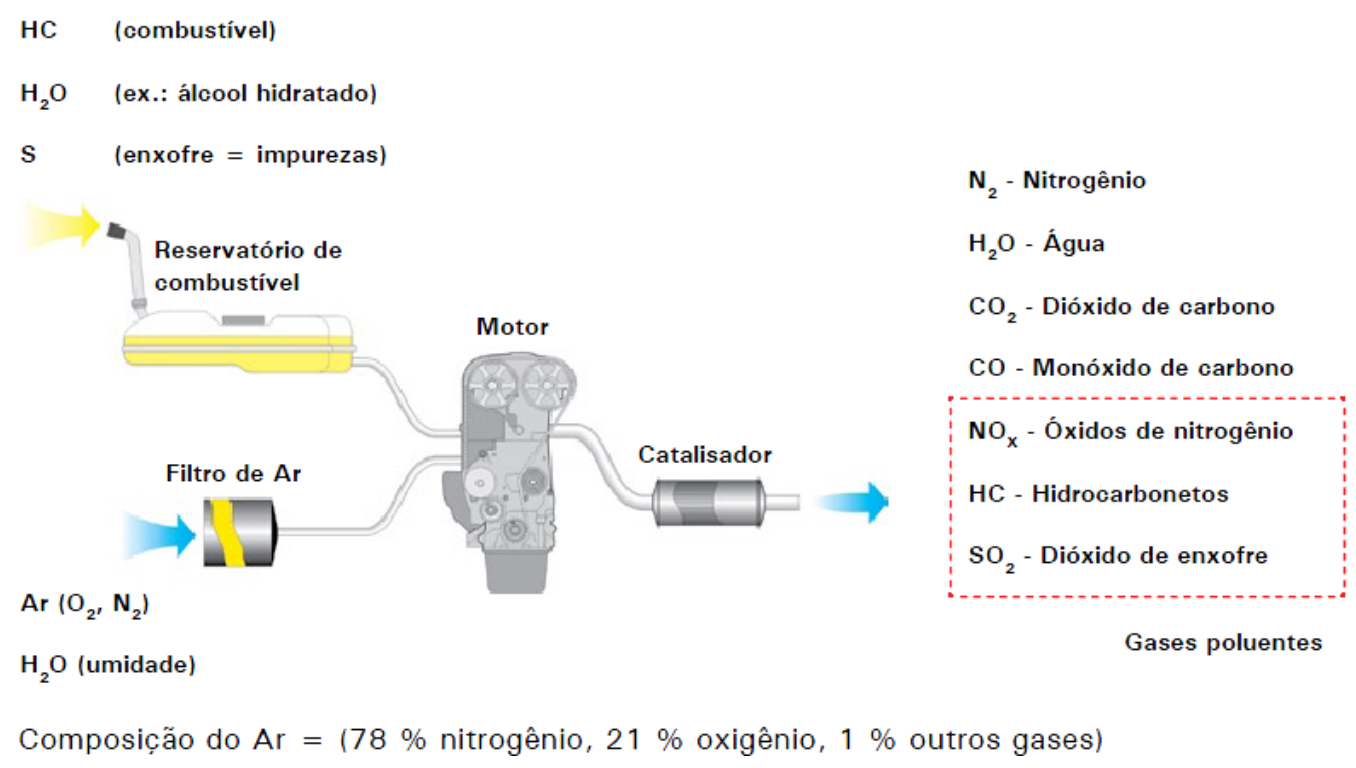

Figura 23 - Gases de Escape de um Motor Ciclo Otto.

(Extraído de VOLKSWAGEN (BRASIL), 2009).

A taxa de poluentes emitidos a cada combustão depende diretamente do fator $\lambda$, pois em cada faixa desse fator há uma emissão maior de um ou outro poluente devido à falta ou excesso de ar, combustível e calor dentro da câmara de combustão.

Na figura 24 é possível observar que com uma mistura rica $(\lambda<1)$ os índices de emissões de hidrocarbonetos e monóxido de carbono são elevados. Isso é resultado de uma combustão imperfeita, gerando hidrocarbonetos (parte do combustível que não foi queimada) e monóxido de carbono (resultante de uma combustão 
incompleta). Já em uma situação inversa, onde existe a falta de combustível, a emissão desses dois gases citados acima diminui, elevando o índice de emissão de NOX, que tem o pico de emissão com a mistura levemente empobrecida $(\lambda=$ 1,05 a 1,1), pois é o momento onde a câmara de combustão atinge sua temperatura mais elevada entre todos os outros níveis de lambda.

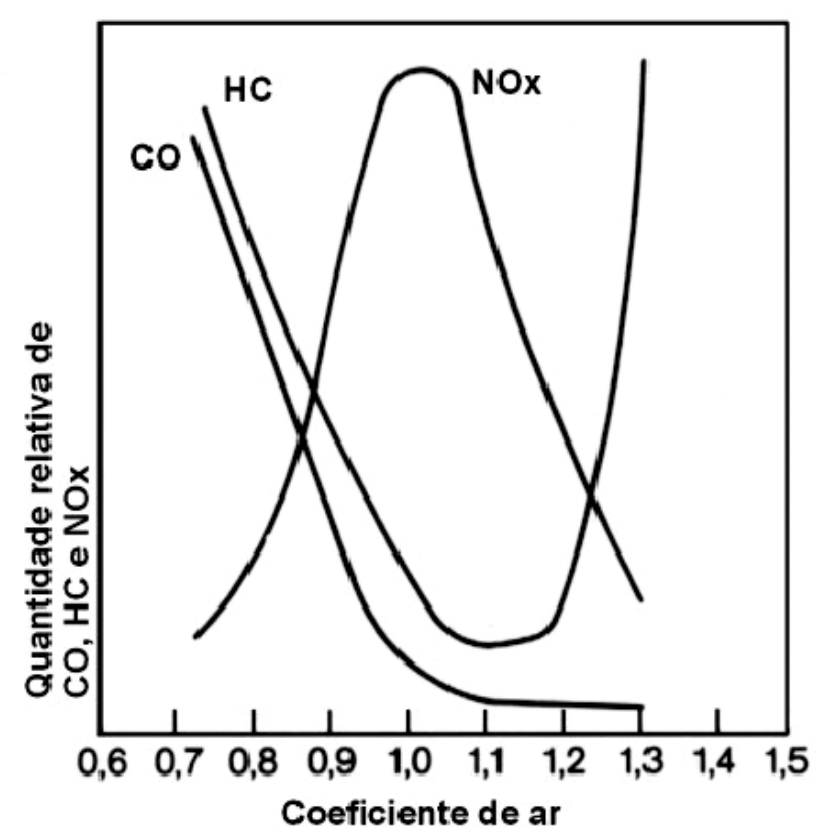

Figura 24 - Gráfico dos gases de emissões relacionados com o fator lambda.

(Extraído de BOSCH, 1995).

Considera-se uma mistura estequiométrica (ideal) quando a resultante da queima dos gases for igual a um fator lambda 1, pois nessa circunstância apesar do elevado índice de emissão de NOX é queimado toda a mistura $A / C$, gerando uma melhor eficiência para o motor.

\subsubsection{Modos de injeção de combustível}

A injeção de combustível pode ser realizada de três modos, dependendo da estratégia do gerenciamento eletrônico que a gerencia, do regime de funcionamento do motor e dos sensores disponíveis para que o gerenciamento seja feito. Esses modos são:

- Sequencial: o gerenciamento do motor atua sequencialmente nas válvulas injetoras, respeitando o ciclo de admissão de cada uma. Sendo que a ordem da maioria dos motores de combustão interna do ciclo Otto é 1, 3, 4 e 2. Isso significa que se o cilindro 1 está no ciclo de admissão em um 
determinado momento, o próximo cilindro que estará no momento de admissão será o cilindro 3 e assim sucessivamente.

- Banco-a-banco: utilizado principalmente em motores que não possuem sensor de fase (sensor que detecta o momento de admissão de cada cilindro). Essa estratégia é conhecida pela injeção dupla das válvulas injetoras. Dessa forma não é necessário saber qual cilindro está no momento de admissão, pois a injeção sempre será feita simultaneamente nos cilindros gêmeos, por exemplo, quando os pistões um e quatro estiverem em movimento descendente dentro dos cilindros 0 gerenciamento do motor acionará a válvula injetora desses cilindros, acontecendo o mesmo nos cilindros dois e três quando estiverem em movimento descendente.

- Full-group: essa estratégia é utilizada principalmente no momento de partida daqueles motores que não possuem sensor de fase. Ela tem a função de garantir a injeção de combustível em todos os cilindros ao mesmo tempo, independente do ciclo em que cada um se encontra. Geralmente essa estratégia é utilizada apenas nas primeiras voltas do motor para propulsioná-lo com uma força maior e conseguir uma partida mais rápida.

\subsection{SISTEMA DE IGNIÇÃO}

Da combustão de uma mistura de ar e combustível nos cilindros de um motor o combustível resulta na energia necessária para mover um automóvel. O sistema de ignição produz a faísca elétrica que inflama a mistura. Cada cilindro possui uma vela provida de dois elementos metálicos - os eletrodos - que penetram na câmara de combustão. Quando a corrente elétrica é fornecida às velas a uma tensão suficientemente elevada, a corrente salta através do intervalo entre os eletrodos sob a forma de faísca (SELEÇÕES DO READER'S DIGEST, 1976).

O sistema de ignição deve realizar, com confiabilidade, a ignição de mistura comprimida em um momento definido com precisão, mesmo sob condições operacionais dinâmicas com as flutuações substanciais nos padrões de fluxo da mistura e relações ar/combustível. A ignição confiável pode ser obtida através da 
seleção das localizações da vela de ignição com um bom acesso da mistura e padrões eficientes de turbilhonamento. Estas são considerações especialmente importantes para uma operação pobre, com aberturas de estrangulamento muito baixas. Melhorias similares também podem ser atingidas através do posicionamento da vela de ignição em pequenas "câmaras de ignição" auxiliares (BOSCH, 2004).

As exigências de energia dependem da relação da mistura ar/combustível. É necessária uma energia de ignição de 0,2 $\mathrm{mJ}$ para misturas de gasolina/ar na faixa estequiométrica, enquanto são necessários $3 \mathrm{~mJ}$ para a ignição de misturas mais ricas ou mais pobres (BOSCH, 2004).

Segundo Pujatti (2007), o sistema de ignição é responsável pelo fornecimento dessa energia desde sua geração até o controle do instante de sua introdução no cilindro através da vela de ignição. É baseado no principio de elevação da tensão fornecida pela bateria (12,0 a 14,0 volts) utilizando um transformador elevador de tensão que na indústria automotiva, é denominada bobina de ignição.

A bobina de ignição é dividida em duas partes: o enrolamento primário e o enrolamento secundário, sendo que há um pino de entrada e um pino de saída para cada enrolamento.

O enrolamento primário é alimentado com a tensão positiva da bateria em um dos seus lados, sendo que o outro recebe o comando da ECU e inicia-se o carregamento da bobina, ou seja, enquanto esse pino estiver aterrado uma corrente flui pelo enrolamento primário da bobina, induzindo dessa forma, uma tensão significativamente maior no enrolamento secundário. Esse tempo em que o primário permanece aterrado é chamado de tempo de permanência ou tempo de carregamento da bobina.

A distribuição da alta tensão de saída do enrolamento secundário pode ser feita mecanicamente através de um dispositivo chamado distribuidor, que por intermédio de engrenagens transfere a rotação do motor para seu eixo central fazendo com que os contatos internos se fechem ordenadamente com o sincronismo do motor. Sendo assim, a centelha estará sempre no cilindro correto no seu ciclo de combustão.

Apesar de esse sistema mecânico ter dominado o mercado automotivo por muitos anos, até praticamente a década de 80 , ele se tornou obsoleto, pois sendo 0 platinado um contato mecânico, possui vida útil reduzida e alta susceptibilidade a diferentes métodos de regulagem. Outra desvantagem é o fato do tempo de permanência ser gerado por meio de um sistema mecânico tipo came-seguidor 
sincronizado com o eixo de manivelas. À medida que a velocidade do motor aumenta, esse tempo tende a se contrair influenciando diretamente na energia induzida no secundário da bobina, sendo esse fator inerente a sua forma construtiva. Por último como desvantagem também havia o avanço de ignição, pois era controlado por um sistema centrífugo que controlava o avanço somente de acordo com a rotação através de dois braços oscilantes montados na parte interna do distribuidor ou um sistema a vácuo constituído de duas câmaras seladas e dividias por um diafragma e um êmbolo que se conectava ao coletor de admissão e de acordo com a depressão do mesmo a ignição era avançada ou atrasada alterando a posição do platinado (PUJATTI, 2007).

Ainda segundo Pujatti (2007), A primeira evolução dos sistemas de ignição foi a substituição do platinado por um driver transistorizado, porém, esses sistemas não eram capazes de maximizar o rendimento do $\mathrm{MCl}$ (Motor de Combustão Interna) em todas as condições de funcionamento. Visando a substituição dos sistemas de controle de avanço mecânicos (a vácuo e centrífugo) foram desenvolvidos os sistemas de ignição eletrônica mapeada.

O controle eletrônico da ignição trabalha a partir do mapa de avanço da ignição do motor. Uma vez detectada a condição de operação, as informações armazenadas nas tabelas são recuperadas corrigindo-se o ponto de ignição que é função da rotação do motor, pressão no coletor de admissão e temperatura do motor. Além de corrigir o ponto (ou ângulo) de ignição em função da condição de operação do motor, o controle eletrônico da ignição controla a ocorrência de knocking, de modo a atrasar o ponto de ignição quando o knock aparece (MILHOR, 2002).

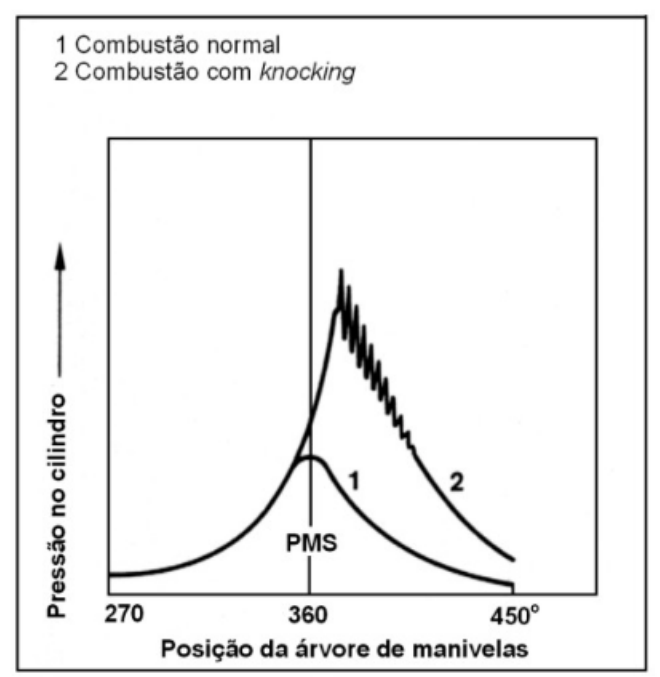

Figura 25 - Pressão de combustão com ocorrência de knocking.

(Extraída de MILHOR, 2002). 
O termo knocking é usado quando ocorre uma detonação na câmara de combustão. Essa detonação pode ser proveniente de reações espontâneas de oxidação nas regiões quentes de carga (mistura ar-combustível) não queimada, sendo que a combustão caracterizada por knocking implica em uma ignição quase instantânea de parte da mistura remanescente, como mostra a figura 25. Ocasionalmente, elevadas pressões localizadas, acompanhadas por ondas de choque e oscilações de pressão com um aumento de transferência de calor ocorrem, por conta deste indevido processo acelerado de combustão (MILHOR, 2002).

\subsection{ESTRATÉGIAS DO GERENCIAMENTO ELETRÔNICO DO MOTOR}

Para se falar de estratégias de gerenciamento do motor, é preciso entender quais são os parâmetros utilizados por uma ECU para criar essas estratégias e como ela trata esses parâmetros em cada uma delas.

Atualmente, um veículo com injeção eletrônica precisa de alguns sinais providos de sensores dispostos no motor para processar essas informações e calcular o tempo de injeção e o momento ideal de disparo dos sistemas de injeção e ignição.

Os sensores básicos para o funcionamento de um sistema de injeção eletrônica são: o de pressão absoluta do coletor de admissão (MAP), o de rotação do motor, o da posição da válvula borboleta, o de temperatura do ar admitido e do motor e a sonda lambda. Contando também com alguns atuadores, como: a bomba de combustível (junto com o relé da bomba) as válvulas injetoras e as bobinas de ignição.

Pode-se afirmar que um gerenciamento eletrônico do motor tem a função de monitorar variáveis, processar e calcular parâmetros, comandar atuadores para que realizem o trabalho necessário para um bom funcionamento do motor e por fim receber feedbacks para o fechamento da malha de controle e com isso conferir os resultados e corrigir caso for necessário. Porém, o motor é um dispositivo que contém vários regimes de operação, e para cada regime é necessário uma estratégia de controle diferente. Serão descritas nas próximas subseções algumas estratégias adotadas por algumas ECUs conhecidas e utilizadas atualmente no mercado automotivo. 


\subsubsection{Partida}

Quando a chave de ignição é ligada, a ECU recebe o sinal de tensão da bateria, e para determinar a duração do tempo de injeção ela se baseia no sensor de temperatura do motor (Figura 26). O sensor MAP também entra nessa estratégia corrigindo o tempo de injeção de acordo com a temperatura do ar admitido. Ao detectar o sinal da chave de partida juntamente com o sinal de rotação a ECU automaticamente dispara todas as válvulas injetoras para garantir uma mistura A/C suficiente para a partida do motor, mantendo-a em uma mistura rica.

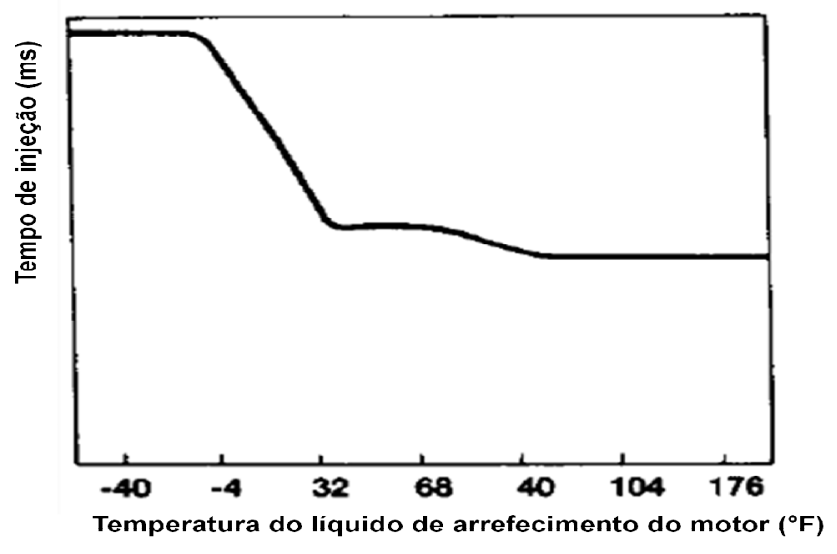

Figura 26 - Gráfico do tempo de injeção x a temperatura do motor.

(Extraído e adaptado de TOYOTA MOTOR SALES, 2008).

\subsubsection{Aquecimento}

Após a partida, o motor entra em um estado de aquecimento, onde a ECU mantém a mistura rica para aquecer rapidamente o motor. Conforme o motor esquenta a ECU corrige a mistura $\mathrm{A} / \mathrm{C}$ diminuindo o tempo de injeção, até entrar na condição de marcha lenta ou aceleração com a temperatura do motor a aproximadamente $90^{\circ} \mathrm{C}$ ou se houver uma solicitação de aceleração pelo pedal do acelerador.

\subsubsection{Marcha Lenta}

Quando o motor está aquecido e não está sendo acelerado ou desacelerado ele permanece no estado de marcha lenta. Neste estado o gerenciamento atua 
sobre um motor de passo ou sobre ou um motor DC conectado ao eixo da própria válvula borboleta por intermédio de engrenagens, abrindo uma passagem de ar (by pass) e controlando a rotação do motor para que ele fique estável e dentro das taxas de emissões (utiliza-se para isso o sensor lambda) mesmo sem o comando do motorista. Esses atuadores de marcha lenta também podem ser usados em outras estratégias para compensar a carga do motor.

\subsubsection{Aceleração}

Nesta fase, a quantidade de combustível fornecida ao motor é aumentada adequadamente de forma a se obter o torque solicitado pelo condutor. A ativação dessa estratégia é executada através das informações provenientes dos seguintes sensores: potenciômetro da posição da borboleta, sensor MAP/MAF, sensor de rotação, sonda lambda e posição do pedal do acelerador em veículos que possuam o acionamento eletrônico do corpo de borboleta (FIAT TREINAMENTO ASSISTENCIAL, 1996).

\subsubsection{Plena Carga}

Durante o funcionamento em plena carga, a mistura é enriquecida para permitir que o motor forneça potência máxima (alcançada fora da relação estequiométrica) e para impedir o aquecimento excessivo do conversor catalítico. Essa condição de funcionamento é detectada através dos valores fornecidos pelos sensores de posição da borboleta, MAP e de posição do pedal do acelerado.

\subsubsection{Desaceleração}

Quando o veículo está em regime de desaceleração existem duas estratégias principais para serem adotadas. O fechamento gradual da válvula borboleta, chamado de dash pot, com a intervenção no atuador de marcha lenta. Isso é feito para evitar solavancos indesejáveis no automóvel e para controlar melhor as emissões de poluentes. Outra estratégia que pode ser adotada na desaceleração do 
motor é o corte de injeção de combustível, chamado de cut off, sendo necessário alguns pré requisitos no motor para que isso aconteça, por exemplo, rotação elevada e motor aquecido. Veja no gráfico da figura 27 a demonstração do cut off ocasionado por excesso de rotações por minuto de um motor:

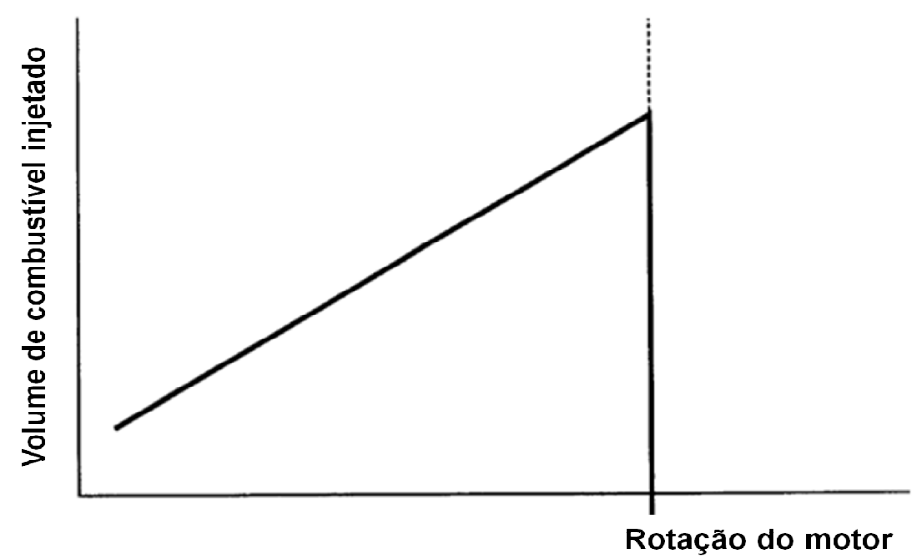

Figura 27 - Gráfico de demonstração do cut off por uma rotação muito elevada do motor. (Extraído e adaptado de TOYOTA MOTOR SALES, 2008). 


\section{METODOLOGIA}

O objetivo deste capítulo é apresentar a metodologia utilizada no desenvolvimento de uma Unidade de Controle Eletrônica para motores de combustão interna do ciclo Otto. Desde os preparativos periféricos de onde aplicá-la, até a demonstração e explicação de todo o hardware e o software desenvolvido para que o objetivo de gerenciar eletronicamente um motor fosse alcançado. Por isso, neste capítulo será tratado o desenvolvimento detalhado de cada etapa desse projeto.

\subsection{DESENVOLVIMENTO DO MOCK-UP}

O uso de mock-ups na indústria automotiva, associados ou não a um dinamômetro, surgiu devido ao aumento da complexidade no desenvolvimento de motores e seus respectivos gerenciamentos, para reduzir o tempo de execução de um projeto e auxiliar no desenvolvimento de novos produtos e treinamentos. Porém, a tecnologia mais utilizada nos atualmente é a simulação virtual de motores, que é chamado pelas indústrias de: mock-up virtual.

Esse tipo de simulação virtual é muito viável somente para as grandes indústrias desenvolvedoras de novas tecnologias. Para grande parte de profissionais fora dessas empresas esse tipo de simulação não é acessível. Portanto, visando o desenvolvimento de uma plataforma didática e de testes para esse e futuros trabalhos na área automotiva focada em gerenciamento de motores, foi construída uma estrutura de aço onde um motor foi fixado juntamente com alguns acessórios, sensores, atuadores e uma ECU, permitindo dessa maneira o funcionamento do motor em um ambiente com fácil acesso e visualização, tornando-se mais fácil a aplicação dos testes iniciais deste projeto.

Para evoluir ainda mais esse mock-up, foi incluído em sua estrutura um dispositivo capaz de interfacear todos os sinais eletroeletrônicos do motor, deixando à disposição para analise todos os sinais de sensores e atuadores conectados ao motor. Isso possibilitou analisar os sinais provenientes, tanto da ECU quanto dos sensores e atuadores e, ainda facilitou os testes de hardware e software desenvolvido neste projeto, diretamente no motor. 
Por isso, nas próximas subseções serão detalhadas cada etapa de desenvolvimento da construção desse mock-up.

\subsubsection{Características Físicas e Eletrônicas do Motor GM}

O motor utilizado para o desenvolvimento e construção do mock-up foi um motor doado pela montadora General Motor do Brasil (GMB) de 1.8 litros flexpower com a tecnologia de funcionamento com bicombustível, ou seja, o combustível para este motor pode ser tanto o etanol quanto a gasolina (Figura 28).

A potência desse motor varia de 114 cavalos $(83,8 \mathrm{KW})$ com o uso exclusivo de etanol até 112 cavalos (82,3 KW) com gasolina, ambos em uma rotação de 5600 rpm. O torque atinge 17,7 kgfm (174 Nm) a $2800 \mathrm{rpm}$ do motor, independente da utilização do combustível (etanol ou gasolina).

Para alcançar esse desempenho, o motor flexpower 1.8 da GMB trabalha com bobinas de ignição dupla com estratégia de acionamento banco a banco (centelha perdida), com um sistema de injeção multiponto e válvulas injetoras de alta impedância na configuração de injeção sequencial, controlada por uma unidade de controle eletrônica doada pela empresa Delphi Automotive. Contudo, essa unidade foi parametrizada para motores que funcionam somente com etanol, por isso, todos os testes com este motor foram realizados com o motor funcionando com esse combustível.

Para a alimentação elétrica dos sensores, atuadores e unidade de controle foi utilizada uma bateria automotiva de 6 células e eletrólito de ácido sulfúrico diluído em água, com capacidade nominal de $12,6 \mathrm{~V}$ e $60 \mathrm{Ah}$ carregada pelo alternador quando o motor está em funcionamento.

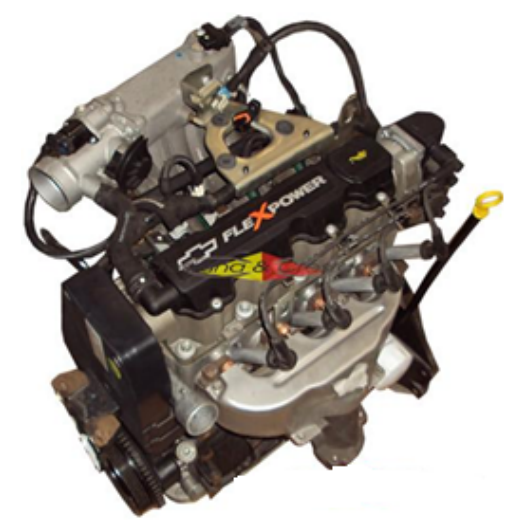

Figura 28 - Motor doado pela GM utilizado na confecção do Mock-up. 


\subsubsection{Construção Mecânica}

A plataforma mecânica de fixação do motor foi baseado num projeto cedido pela escola Senai de Lençóis Paulista, que tem um bom conhecimento na construção desse tipo de sistema. Com o esquema mecânico em mãos a Oficina Mecânica do Laboratório de Sistema Integráveis do Departamento de Sistemas Eletrônicos da EPUSP auxiliou na montagem da estrutura de aço utilizada para a fixação do motor, assim como toda a etapa de fixação do mesmo nessa estrutura.

Para se evitar vibrações do motor na gaiola de aço, foram utilizados coxins de borracha que absorvem partes das vibrações produzidas pelo motor e maximiza a vida útil de todo o sistema. Além disso, aproveitando a furação de fixação da caixa de transmissão no motor, foi realizada uma fixação de uma caixa seca no motor que, posteriormente foi fixada também na gaiola de aço.

Foi construído também um reservatório de combustível em aço inox onde foi acoplada uma bomba de combustível e ainda para o complemento do mock-up foram instalados: um alternador, bateria, painel de instrumentos, comutador de ignição montado na coluna de direção, sistema de arrefecimento, reservatório de água e reservatório de partida a frio. Com isso, todo o desenvolvimento da estrutura mecânica do mock-up se encerrou (figura 29).

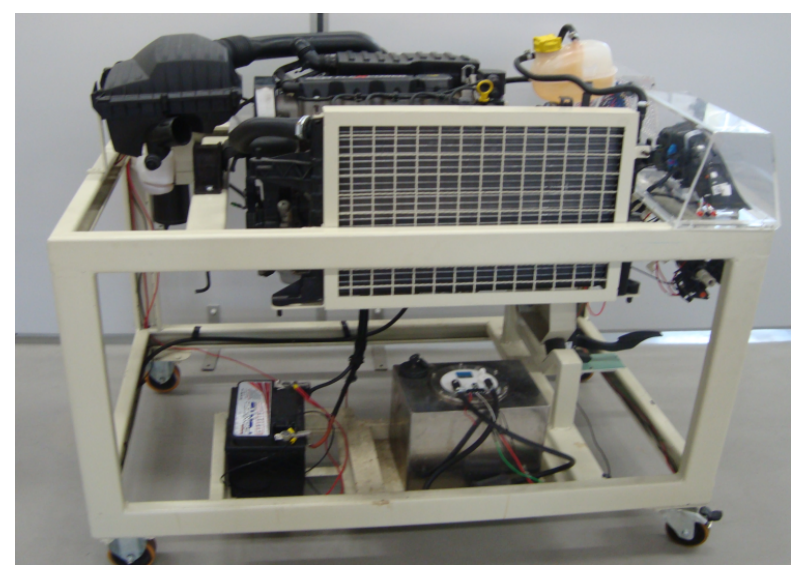

Figura 29 - Mock-up.

Desses acessórios instalados no mock-up, o comutador de ignição é um componente que merece uma explicação mais aprofundada, pois algumas nomenclaturas de bornes de saída dele serão utilizadas posteriormente.

Um comutador de ignição básico é composto de um contato de entrada e três grupos de contatos de saída. Cada grupo de contatos de saída possui no mínimo 
três posições que podem ser variadas de acordo com a posição da chave dentro do comutador, como pode ser visto na figura 30.

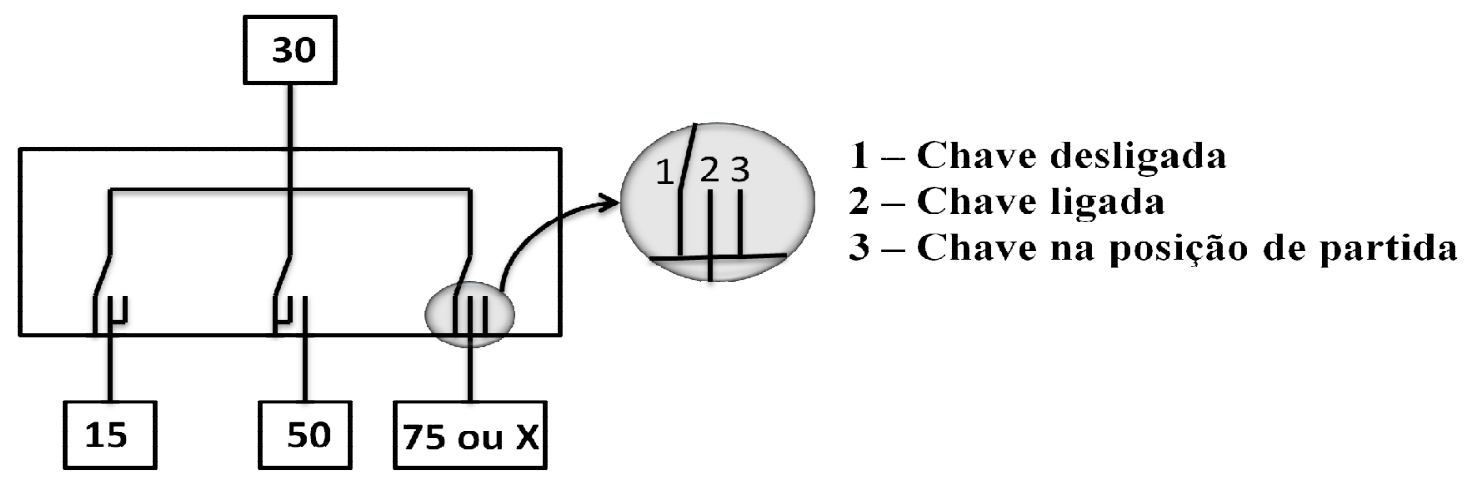

Figura 30 - Comutador de Ignição.

$\mathrm{Na}$ industria automotiva é muito comum a utilização da denominação ou "linha30" para representar.a linha de alimentação vinda da bateria e "linha 15" após uma chave geral. Isso acontece devido a nomenclatura dos bornes do comutador de ignição. Por isso, segue abaixo o significado de cada um desses bornes:

- Borne 30 ou linha 30: É o borne de alimentação do comutador de ignição que carrega um sinal de aproximadamente $12 \mathrm{~V}$ proveniente diretamente da bateria.

- Borne 15 ou linha 15: Também conhecido como pós-chave, esse borne fica ativo sempre que a chave de ignição está ligada, tanto no primeiro estágio quanto no estágio de partida.

- Borne 50 ou linha 50: Só fica ativo quando a chave de ignição está na posição de partida. Sua saída envia o sinal positivo para o relé de partida.

- Borne 75/X ou linha 75/X: Essa linha é utilizada para alimentar os acessórios e componentes que são irrelevantes para a partida, pois no momento te partida não há sinal positivo nesse borne. Isso porque no momento de partida é necessário que o máximo de corrente flua para o motor de partida.

\subsubsection{Construção Elétrica}

No primeiro momento, para verificar o funcionamento do motor, a ligação elétrica entre sensores, atuadores, bateria e unidade de controle foi feita através do chicote original do motor. Porém, por se tratar de um chicote original, muitos 
conectores, fusíveis e relés contidos no mesmo não eram utilizados, pois nele continha ligações elétricas para todo o veículo. E uma vez que só o motor estava sendo conectado com ele, muitos conectores e outros componentes utilizados em funções diversas no veículo ficaram sobrando, deixando dessa forma o mock-up muito carregado de fios inutilizados.

Além disso, com a ideia de se fazer a intersecção entre a ECU e os sensores e atuadores do motor foi necessário alterar a disposição do chicote elétrico do motor. Porém, isso não foi possível fazer com o chicote original cedido pela montadora, sendo então confeccionado um novo chicote dedicado somente para as funções contidas nesse motor.

Com essa solução dedicada foi possível diminuir significadamente a quantidade de fios no mock-up, melhorando a visão estética do mesmo, uma vez que com esse novo design todos os fios foram passados pelas canaletas da estrutura metálica. Além disso, foi possível interfacear todos os sinais da ECU com os sensores e atuadores, pois antes de levar os fios dos sensores para a ECU eles foram passados por uma placa de interface, que será descrita na próxima subseção, e depois foram encaminhados até a ECU. Na figura 31a pode ser visualizado o mock-up com o chicote original e na figura 31b o mock-up já está com a nova disposição de fios.

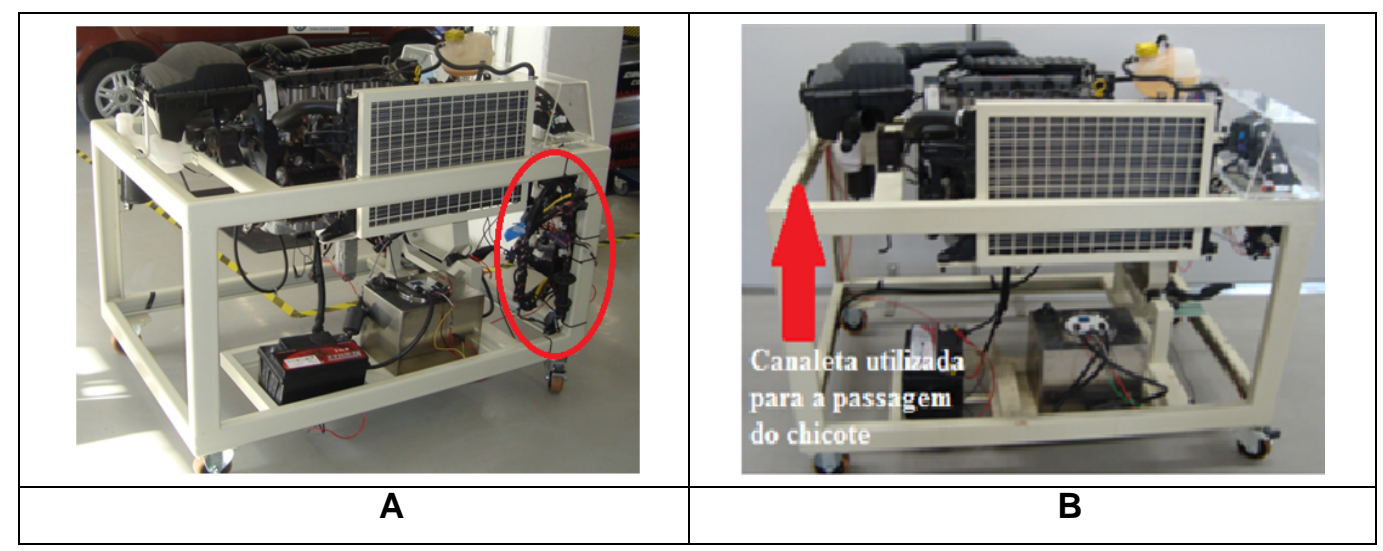

Figura 31 -A) Mock-up com chicote elétrico original. B) Mock-up com chicote elétrico novo.

\subsubsection{Intersecção da ECU}

A intersecção da ECU visa facilitar a observação de sinais gerados tanto pelos sensores quanto pela ECU para comandar os atuadores. Além de possibilitar o 
teste parcial ou completo de novos dispositivos ou soluções tecnológicas, substituindo as funções executadas pela ECU original por controles inovadores criados em estudos dedicados ao aprimoramento de um componente específico do motor.

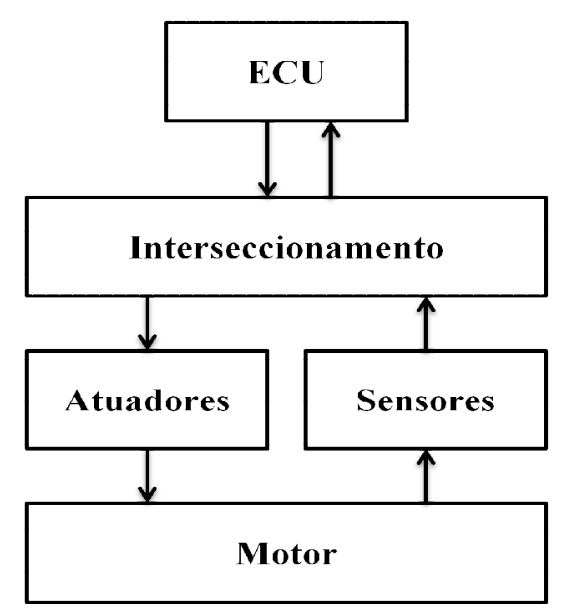

Figura 32 - Diagrama de blocos da intersecção os sensores e atuadores da ECU.

A intersecção ilustrada na figura 32 exemplifica o que foi feito na prática. Todos os fios da ECU antes de chegarem no chicote do motor passam antes por um painel onde está localizado bornes e chaves. Os bornes tem a função de permitir o acesso aos sinais de sensores e controle da ECU aos atuadores. Já as chaves, por sua vez, tem o objetivo de interromper um sinal de comando originado da ECU, pois com isso é possível introduzir sinais de comandos externos gerados por controladores desenvolvidos com o intuito de aprimorar alguma parte do motor.

A primeira intersecção da ECU foi desenvolvida em uma caixa de acrílico (Figura 33a). Com esse dispositivo foi possível observar diversos sinais utilizando-se um osciloscópio ou ainda simular algumas falhas, desligando os sinais através das chaves onde foram soldados os fios.

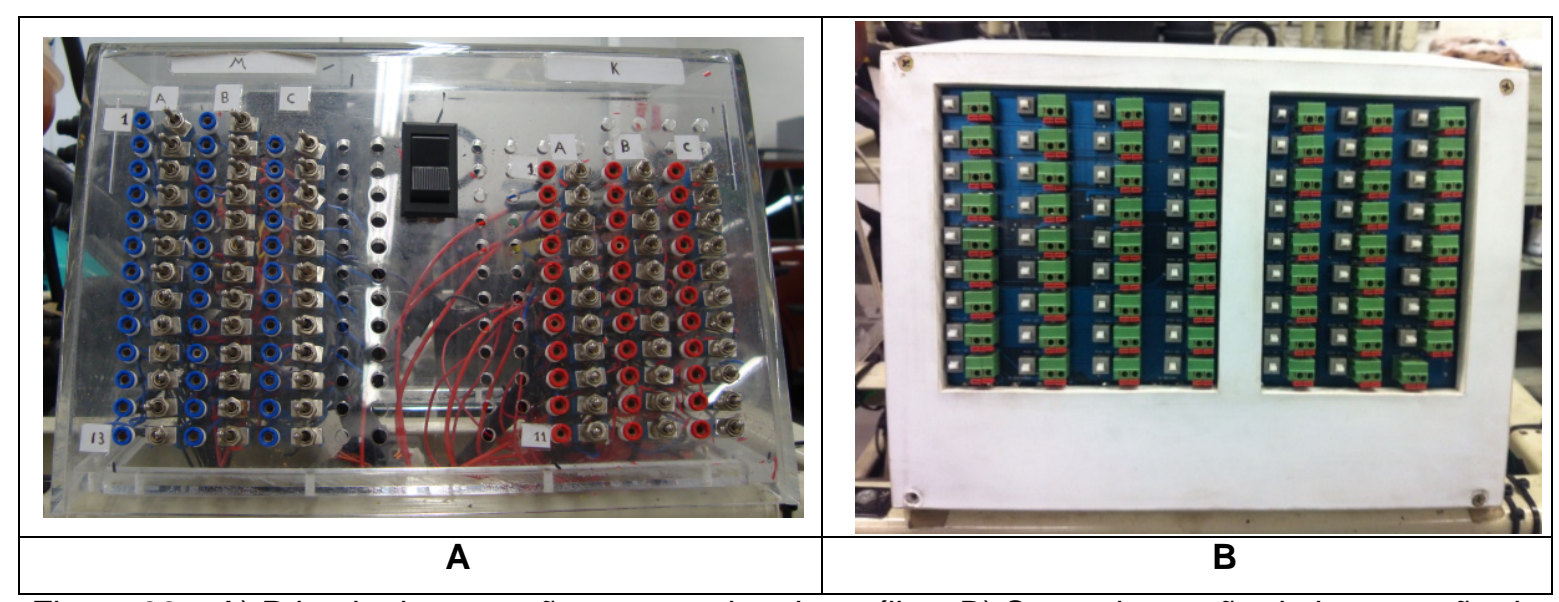

Figura 33 - A) Primeira intersecção com a caixa de acrílico, B) Segunda versão da intersecção da ECU. 
Porém, essa primeira intersecção não se mostrou eficiente o bastante para bom andamento dos testes, pois sua confecção foi realizada manualmente com bornes passíveis de mau contato. Por esse motivo foi necessário o desenvolvimento de outro sistema de intersecção da ECU.

A ideia foi transformar a caixa de acrílico em uma placa de circuito impresso que executasse a mesma função, porém reduzindo ao máximo os problemas mencionados. Foram construídas duas placas: uma receber os fios originados da ECU e a outra para armazenar os conectores duplos (para observar os sinais e introduzir novos sinais de controle) e push-bottom's (para desligar o comando originado da ECU que controlaria algum atuador) (Figura 33b).

Com essa solução foi possível criar um dispositivo de interfaceamento entre a ECU, sensores e atuadores totalmente confiável, capaz de ligar e desligar sinais provenientes tanto da ECU para comandar algum atuador quanto de algum sensor para comunicar à ECU o estado de alguma grandeza física controlada eletronicamente.

\subsection{DESENVOLVIMENTO DO HARDWARE}

Esta seção apresenta o desenvolvimento do hardware de uma Unidade Eletrônica de Controle (ECU) para motores de combustão interna ciclo Otto que foi desenvolvida e está sendo utilizada em conjunto com o grupo de pesquisa composto por professores e alunos da FATEC Santo André e da EPUSP. Será apresentada sua arquitetura, descrição dos blocos integrantes dos circuitos de interface, bem como as principais características dos microcontroladores utilizados.

Descrevem-se a seguir as principais diretrizes fixadas para este projeto. Foi estabelecido, para o desenvolvimento da ECU, um processo evolutivo passando por várias versões de hardware e o aprimoramento constante dos softwares, adicionando-se a cada etapa novas funções. Portanto, esta primeira versão, deverá apresentar condições mínimas para serem aplicadas em mock-ups e automóveis, com blocos básicos de softwares sem sofisticações. Uma segunda versão foi desenvolvida com a mesma função da primeira, porém com circuitos mais avançados de condicionamento de sinal e atuação nos componentes do motor. 
A ECU terá três blocos básicos, respectivamente, gerenciamento, sincronismo e comunicação/diagnose. O bloco de gerenciamento receberá os sinais de diversos sensores e deverá identificar o regime de operação do motor e estabelecer os parâmetros adequados para os diferentes atuadores, fundamentalmente, válvula borboleta, válvulas injetoras e bobinas de ignição.

O bloco de sincronismo terá a função de gerar, a partir do sinal da roda fônica e de parâmetros determinados pelo bloco de gerenciamento, pulsos para o controle da abertura das válvulas injetoras de combustível e do sistema de ignição.

O bloco de comunicação e diagnose terá a função de receber informações do bloco de gerenciamento e disponibilizá-las em um barramento da rede CAN e também apresentá-las em um display de LCD, porém somente foi desenvolvido para esse bloco o hardware, pois o software está sendo fruto de outros trabalhos de mestrado e graduação.

Serão descritas a seguir duas versões de hardware para os blocos de gerenciamento e sincronismo, pois os testes se iniciaram em uma primeira versão onde foram implementados circuitos simples de interface para comandar os atuadores. Porém, esses circuitos não se mostraram eficientes o bastante para continuar com a evolução dos testes práticos, sendo necessária a substituição do hardware para uma segunda versão.

\subsubsection{Circuitos de Interface}

No projeto da primeira versão da ECU, a utilização de componentes mais simples para os circuitos de interface de comando dos atuadores foi estabelecida.

Desta forma, foram aplicados os circuitos de condicionamento de sinais para as entradas digitais e analógicas dos sinais provenientes da maioria dos sensores, da tensão da bateria e do sensor de nível do tanque de combustível. Foram aplicados também circuitos de interface para os atuadores, tais como: as válvulas injetoras de combustível, as bobinas de ignição e a válvula borboleta.

As principais alterações da primeira para a segunda versão foram:

1. O condicionamento dos sinais de entrada dos sensores, pois na primeira versão cada sensor alimentava uma porta de entrada do microcontrolador. Já na segunda versão foi utilizado um multiplexador, 
portanto somente uma porta do microcontrolador recebia os sinais provenientes dos sensores do motor.

2. A atuação nas válvulas injetoras na primeira versão é feita através do circuito integrado LM1949 para cada componente atuando na base de um transistor. Na segunda versão esse papel é realizado por apenas um circuito integrado: o MC 33810, que já atua direto na base dos transistores de acionamento das bobinas e dispensa a necessidade de transistores para as válvulas injetoras.

Como o este trabalho foi inicialmente desenvolvido na primeira versão do e,posteriormente adaptado para a segunda versão, serão apresentados primeiramente os circuitos utilizados na primeira versão seguindo com as alterações realizadas para a segunda versão.

\subsubsection{Microcontrolador}

Foi definido para esta primeira versão o microcontrolador PIC 18F452 que apresenta uma memória de programa de 32k bytes e memória de dados de 1536 bytes. Em testes experimentais, com o software desenvolvido, verificou-se que 0 microcontrolador operando a $20 \mathrm{Mhz}$ funciona sem apresentar problemas quanto a tempo de processamento, sendo que uma validação para esta aplicação requer testes mais rigorosos em condições reais de gerenciamento. $O$ bloco de gerenciamento, que exigirá a utilização de parte da memória de programa para o armazenamento de mapas, será atendido pelo microcontrolador, permitindo a obtenção de espaço suficiente para armazenamento de todas as tabelas. O leitor interessado em maiores detalhes técnicos do microcontrolador $18 \mathrm{~F} 452$ poderá consultar o data sheet do fabricante (MICROCHIP, 2006).

\subsubsection{Descrição da ECU}

Apresenta-se a seguir a descrição geral da unidade eletrônica de controle deste projeto, onde a figura 34 representa o diagrama geral da ECU. Deve-se observar que a comunicação entre o bloco de gerenciamento e o bloco de 
sincronismo é feito via protocolo SPI (Serial Peripheral Interface), e a comunicação entre o bloco de gerenciamento e o bloco de comunicação é realizada via USART (Universal Synchronous and Asynchronous Receiver Transmitter) dos respectivos microcontroladores.

A arquitetura descentralizada em três blocos distintos aconteceu por duas razões: tornar-se uma plataforma didática com um poder de ensino melhor das funções de cada bloco quando estão separados, permitindo que essa plataforma seja usada em desenvolvimentos de recursos humanos na área de eletrônica automotiva embarcada; e proporcionar o desenvolvimento de projetos em paralelo, ou seja, executando a divisão das tarefas entre o grupo de pesquisa. Onde cada membro do grupo é responsável por desenvolver o software de um bloco diferente, reduzindo o tempo investido em produção de software, por exemplo.

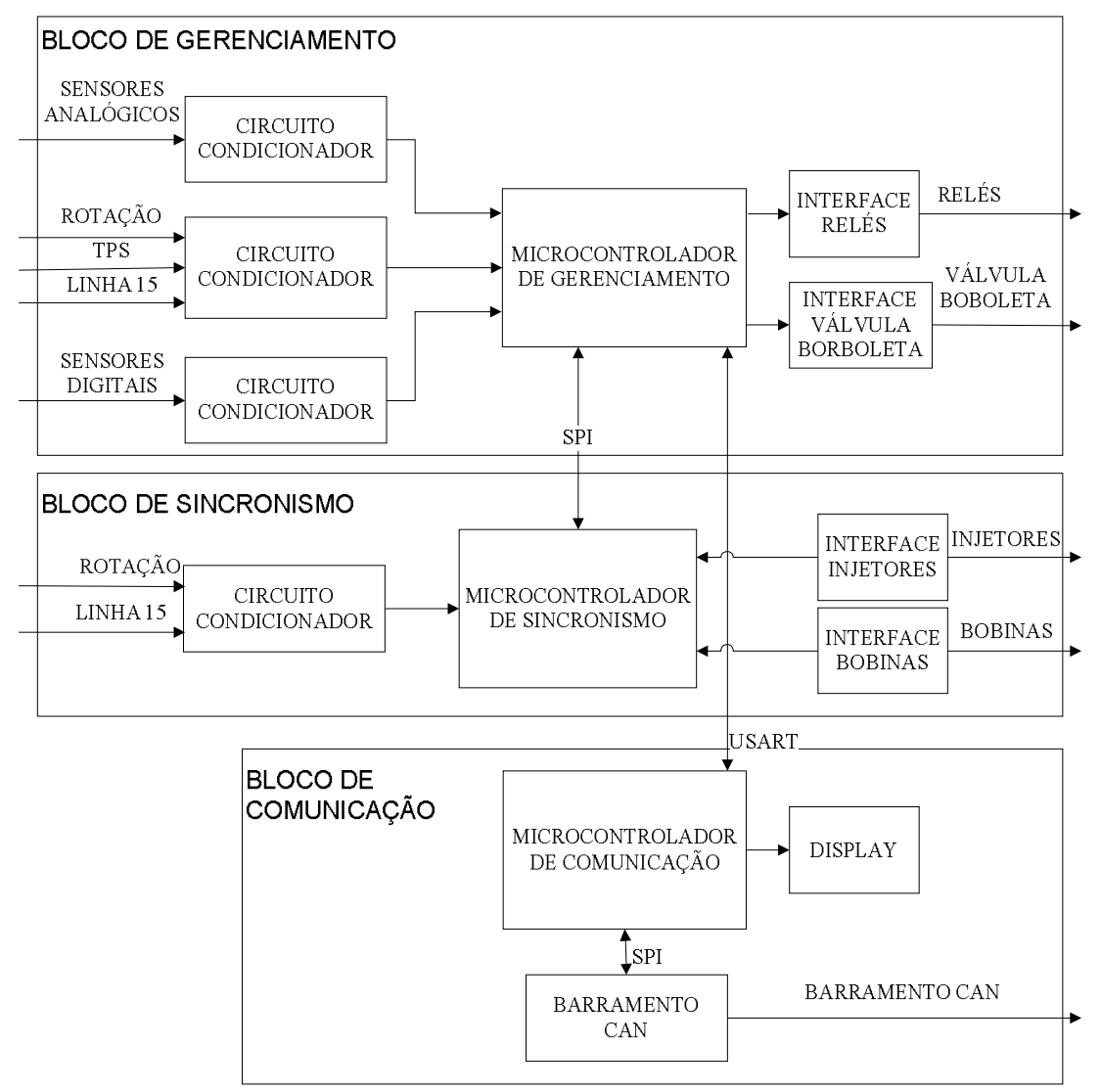

Figura 34 - Diagrama de blocos da ECU.

\subsubsection{Bloco de Gerenciamento}

O hardware referente ao bloco de gerenciamento da primeira versão é constituído de circuitos de condicionamento para os sinais analógicos e digitais, 
circuito de enquadramento do sinal proveniente da roda fônica, microcontrolador PIC 18F452 e interface de controle da válvula borboleta. Este bloco pode ser visualizado na figura 35 através da disposição de pinos do PIC 18F452.

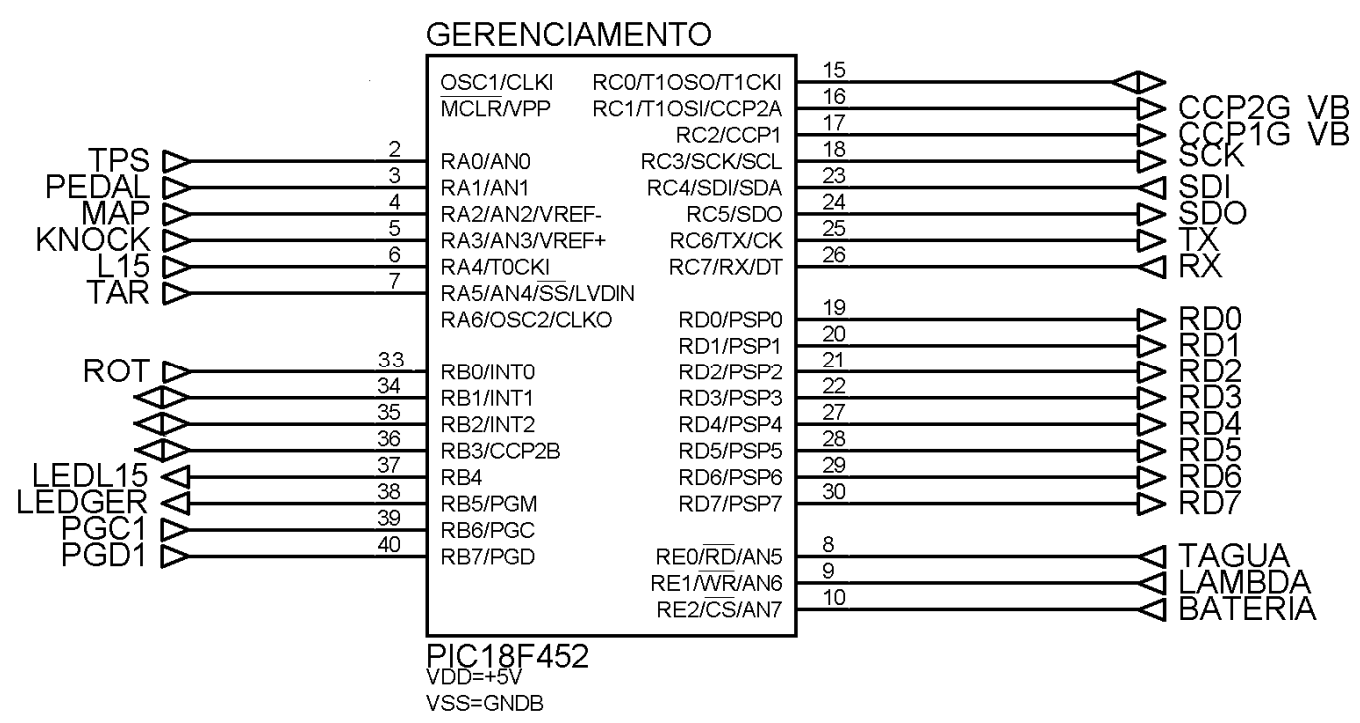

Figura 35 - Distribuição dos pinos no microcontrolador de gerenciamento da primeira versão do hardware.

Antes de entrar nas portas do microcontrolador os sinais dos sensores analógicos passam por circuitos condicionadores, visando garantir alta impedância, proteção, filtros de ruídos e atenuação ou amplificação quando necessário:

As entradas com sinais analógicos provenientes desses sensores seguem listadas abaixo, e estão conectadas nas portas A e E do microcontrolador:

- Porta A0 (pino 2): Sensores de posição da válvula borboleta (TPS);

- Porta A1 (pino 3): Sensor de posição do pedal do acelerador

- Porta A2 (pino 4): Sensor de pressão (MAP)

- Porta A3 (pino 5): Sensor knock (detonação) (somente para projetos futuros);

- Porta A5 (pino 7): Sensor de temperatura do ar de admissão;

- Porta E0 (pino 8): Sensor de temperatura do líquido de arrefecimento do motor;

- Porta E1 (pino 9): Sensor lambda;

- Porta E2 (pino 10): Tensão da bateria.

O circuito de condicionamento utilizado pelos sensores descritos acima podem ser visualizado na Figura 36 a seguir. 


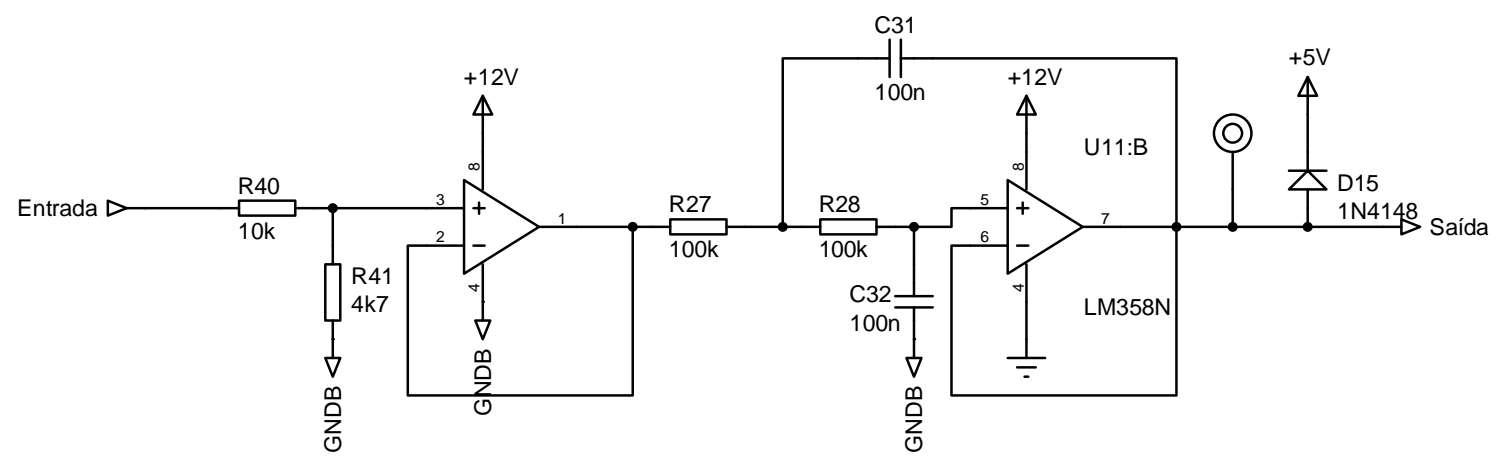

Figura 36 - Circuito de condicionamento dos sensores analógicos.

Este circuito possui na entrada um divisor de tensão resistivo para atenuar a tensão que varia de 0 a 14 Volts para evitar que os sinais excedam os 5 volts suportados pela entrada do microcontrolador. Caso o sinal seja de um sensor alimentado pela ECU (5V) ele não terá esse divisor de tensão no início. Além disso, todos os circuitos de tratamento para sinais analógicos possuem também, um amplificador operacional (LM358) configurado como seguidor de tensão que tem a função de isolar a impedância do sensor do resto do circuito da ECU e outro amplificador operacional (LM358) configurado como filtro ativo de segunda ordem na topologia Sallen key do tipo passa baixa. A frequência de corte deste circuito é dada pela eq. 7 (DIAS, 2011).

$$
\mathrm{F}_{\mathrm{c}}=\frac{1}{2 \pi \sqrt{\mathrm{R}_{\mathrm{C}} \mathrm{R}_{\mathrm{D}} \mathrm{C}_{\mathrm{A}} \mathrm{C}_{\mathrm{B}}}}
$$

Há somente dois sinais para as entradas digitais, como descritos abaixo, e antes de entrar nas portas do microcontrolador são condicionados pelo circuito da figura 37:

- Porta A4: Sinal de linha 15;

- Porta B0: Sinal do sensor de rotação condicionado pelo LM1815.

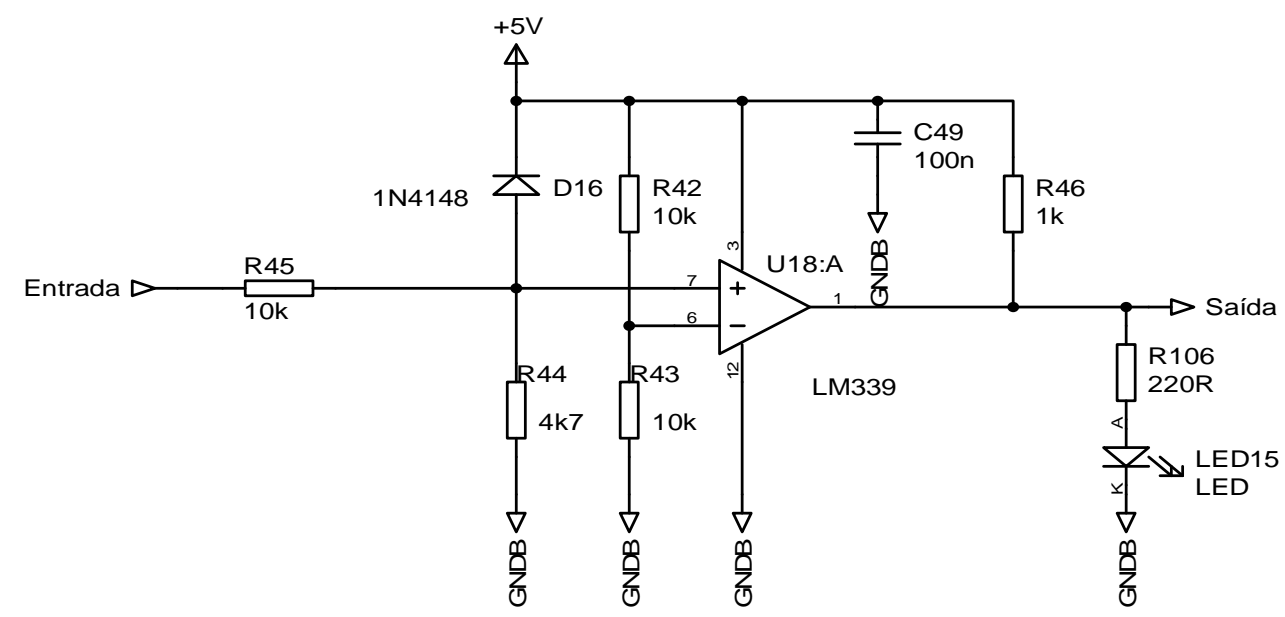

Figura 37 - Circuito de condicionamento dos sensores digitais. 
Este circuito possui na entrada um divisor de tensão resistivo para atenuar a tensão que varia de 0 a 12 Volts na entrada. Assim como um diodo (1N4148) que tem a função de grampear a tensão de entrada para no máximo 5,7 Volts para proteger o microcontrolador contra sobretensões. Possui também um amplificador operacional (LM339) que tem a função de efetuar uma comparação entre a tensão de entrada (terminal positivo) e uma tensão de referência efetuada pelo divisor resistivo no terminal negativo (2,5 Volts). Caso a tensão de entrada dividida seja maior que a tensão de referência, a saída do amplificador operacional terá aproximadamente 5 Volts (nível lógico 1), caso a tensão de entrada seja menor que a tensão de referência, a saída do amplificador operacional terá aproximadamente 0 Volts (nível lógico 0). Existe também na saída do amplificador operacional um resistor de pull-up (DIAS,2011).

Ainda há como entrada, um sinal senoidal proveniente do sensor de relutância variável da roda geradora de impulsos que passa pelo circuito de enquadramento do sinal. Vale ressaltar que o sinal senoidal quando cruza zero Volt no semiciclo positivo para o negativo coincide com a subida do dente. No instante que o sinal cruzar zero Volt do semiciclo negativo para o positivo, coincidirá com a descida do dente.

O circuito integrado utilizado para o enquadramento de sinal é o LM1815 que permite três modos de funcionamento determinado pelo pino 5. Foi escolhido para esse trabalho o terceiro modo de operação que gera pulsos quadrados onde o flanco de subida destes pulsos coincide com o cruzamento ao zero do semiciclo positivo para o negativo e a largura do pulso é estabelecida por um circuito RC conectado no pino 14. Estabeleceu-se uma largura de pulso de aproximadamente $100 \mu \mathrm{s}$, como determinado pela eq. 8, por ser menor do que o intervalo de tempo correspondente a meio período do sinal de entrada. Este circuito pode ser visualizado na Figura 38.

$$
\text { largura de pulso }=0,673 * R * C
$$

Como o sinal enquadrado do sensor de relutância foi obtido em todos os ranges de rotação do motor através do pino 12 do Cl LM1815 foi desnecessária a utilização dos pinos 9,10 e 11 do mesmo.

Na porta B do microcontrolador ainda estão conectado nos pinos 37 e 38 dois LEDs de indicação: o primeiro indica se a chave de ignição foi ligada e o segundo se o microcontrolador de gerenciamento foi energizado. As portas RB1, RB2, RB3 e RC0 são portas reservas que serão utilizadas caso haja a necessidade de fazer a 
leitura ou comando de algum sensor ou atuador que não foi planejado no início do projeto. Os pinos PGC1 e PGD1 são usados para a gravação do software no microcontrolador.

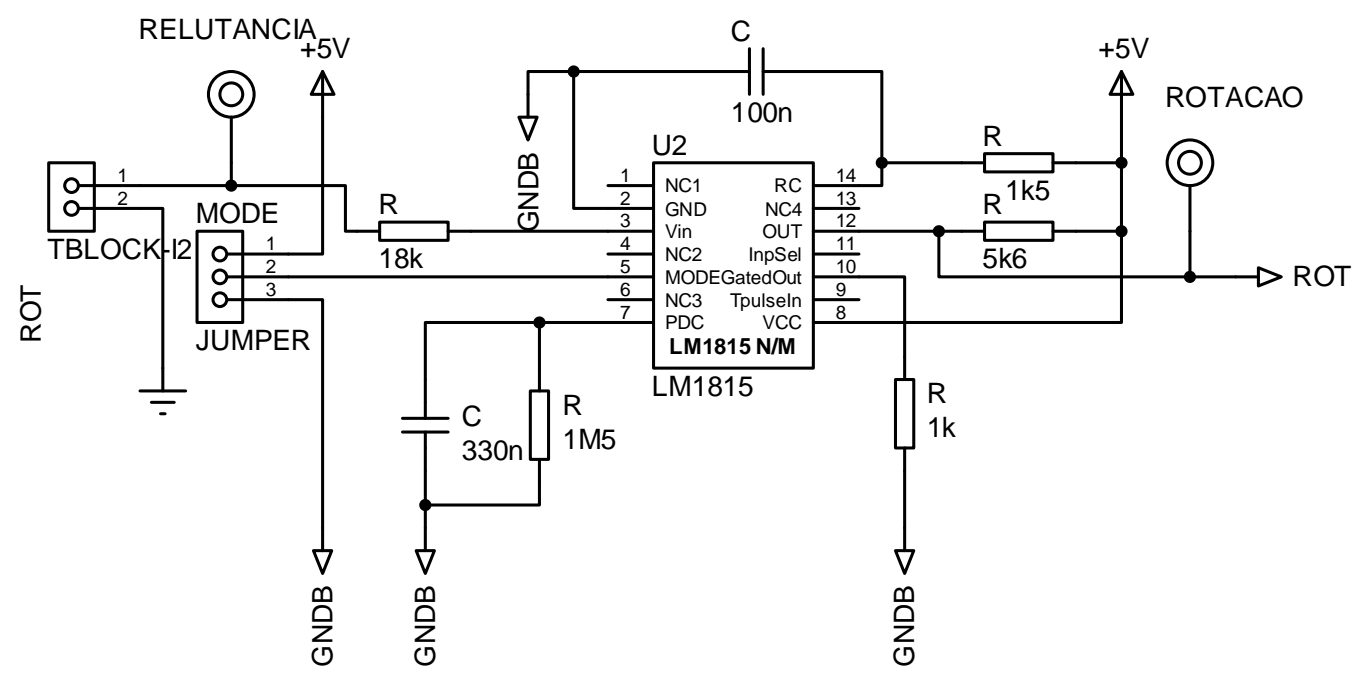

Figura 38 - Circuito condicionador do sensor de relutância variável.

As portas RC1 e RC2 são exclusivas para o controle da válvula borboleta e estão conectadas diretamente no circuito de interface para seu controle, como ilustrado na figura 39. O Cl utilizado para executar o controle da válvula borboleta foi o MC33926. Ele foi escolhido porque atende os requisitos para controlar uma válvula borboleta, já que a corrente máxima que ele suporta é de $5 \mathrm{~A}$, bem maior que a corrente de aproximadamente $2 \mathrm{~A}$ requerida pela válvula borboleta. Além disso, esse $\mathrm{Cl}$ é capaz de responder a sinais de entrada de até $20 \mathrm{Khz}$ de frequência (Freescale (2007)), 13 vezes maior que o mínimo aceitável para controlar o motor de uma válvula borboleta (Delphi, 2003).

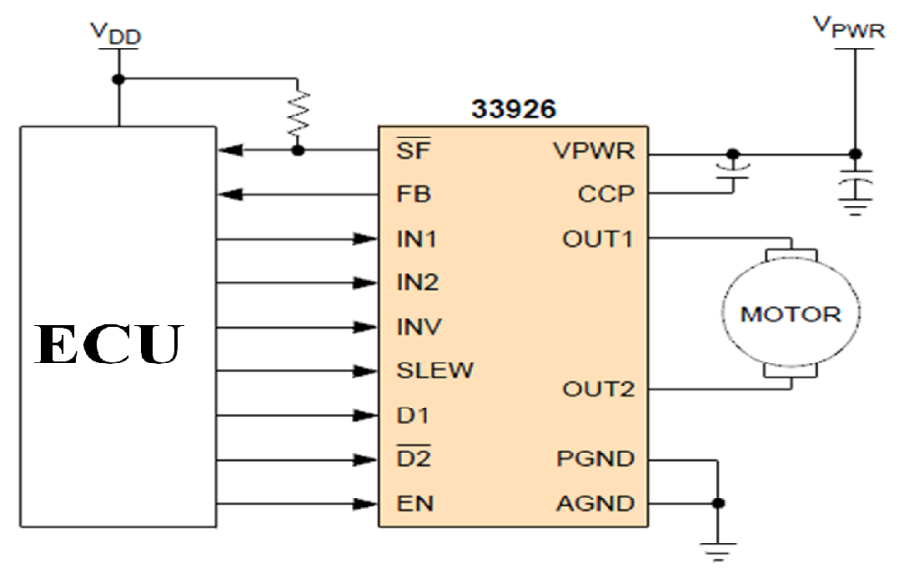

Figura 39 - Diagrama simplificado de aplicação da interface da válvula borboleta.

(Extraído e adaptado de FREESCALE, 2007). 
Continuando a descrição da porta $C$, os próximos pinos (RC3 até $R C 7$ ) são utilizados para a comunicação SPI e USART com o microcontrolador de sincronismo e comunicação respectivamente, sendo respectivamente SCK o clock da comunicação SPI, SDI a entrada do sinal de comunicação SPI, SDO a saída do sinal de comunicação SPI, TX a saída do sinal de comunicação USART e RX a entrada do sinal de comunicação USART.

A porta $\mathrm{D}$ foi direcionada para acionamento de relés, porém as únicas saídas utilizadas até o momento foram as portas D1, D2 e D3, acionando respectivamente os relés do motor de partida, bomba de combustível e alimentação geral dos componentes do motor.

\subsubsection{Alterações Realizadas na Segunda Versão do Hardware de Gerenciamento}

Na nova versão do hardware as disposições dos pinos de entradas e saídas das portas do microcontrolador se alteram devido a introdução do multiplexador MC33972 (FREESCALE, 2007) na porta RA0 para fazer a leitura dos sinais de todos os sensores. Com isso foi possível utilizar uma única porta para fazer essa leitura, liberando as outras portas para outras finalidades como pode ser observado na figura 40.

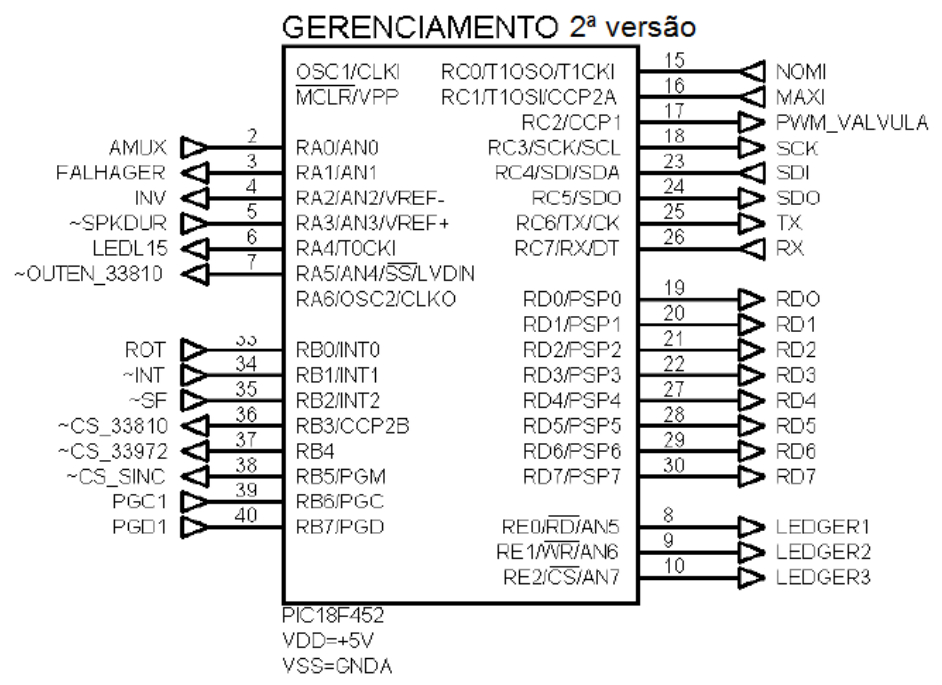

Figura 40 - Distribuição dos pinos no microcontrolador de gerenciamento da segunda versão do hardware.

Das funções novas incorporadas nessa nova versão de hardware vale ressaltar as portas RB3, RB4 e RB5 que foram utilizadas como chip select da 
comunicação SPI que nessa nova versão será realizada entre microcontrolador de gerenciamento e sincronismo, MC33810 (Cl para atuação no sistema de injeção e ignição que será visto na próxima subseção) e o MC33972, tendo como mestre o bloco de gerenciamento.

A inclusão da saída INV na porta RA2 que está conectada no circuito de interface da válvula borboleta e tem a função de inverter a polaridade do motor para o fechamento mais rápido da válvula borboleta também foi introduzida.

Os pinos 5, 15 e 16 do microcontrolador tem a função de receber sinais provenientes do MC33810, com informações úteis para diagnóstico do sistema de ignição. Porém esses pinos assim como os pinos 34 e 35 foram projetados nessa versão com uma prospecção de utilização em futuros projetos, não sendo aplicados nesse trabalho. Já o pino OUTEN_33810 tem a função de habilitar o funcionamento do MC33810 quando está em nível lógico zero.

\subsubsection{Bloco de Sincronismo}

O bloco de sincronismo (figura 41) da primeira versão é constituído de um microcontrolador PIC18F452 e circuitos de interfaces para o acionamento das válvulas injetoras de combustível e bobinas de ignição.

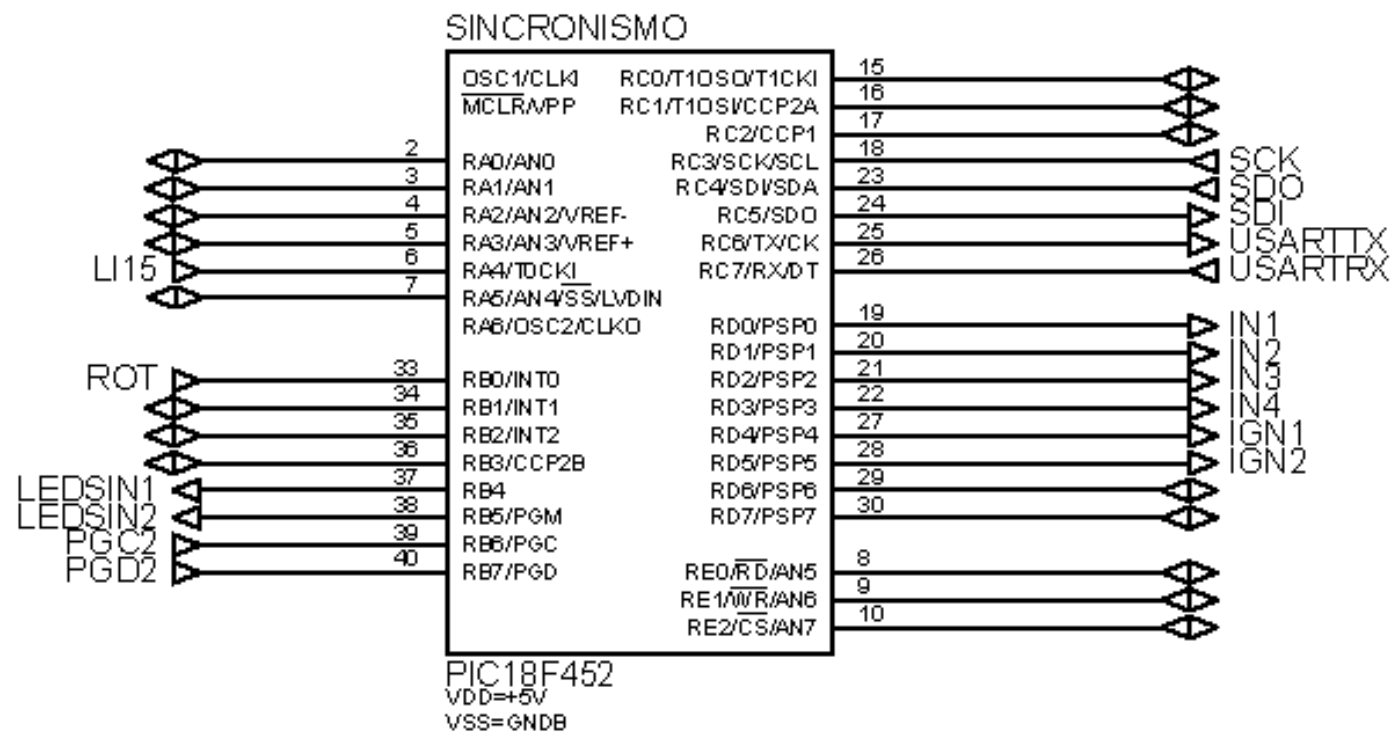

Figura 41 - Distribuição dos pinos no microcontrolador de sincronismo.

Os circuitos de interface para o acionamento das válvulas injetoras de combustível e os circuitos para a bobina de ignição são semelhantes. Um diodo Zener de 33 volts para o acionamento das válvulas injetoras e dois diodos Zener de 
160 volts para o acionamento das bobinas de ignição. A função destas interfaces é chavear altas correntes, características destes atuadores, aproximadamente $1 \mathrm{~A} \mathrm{e}$ $10 \mathrm{~A}$ respectivamente, e propiciar que o transistor de potência atue fortemente saturado no inicio de sua operação, acelerando a abertura da válvula injetora. Este circuito pode ser visualizado na figura 42 .

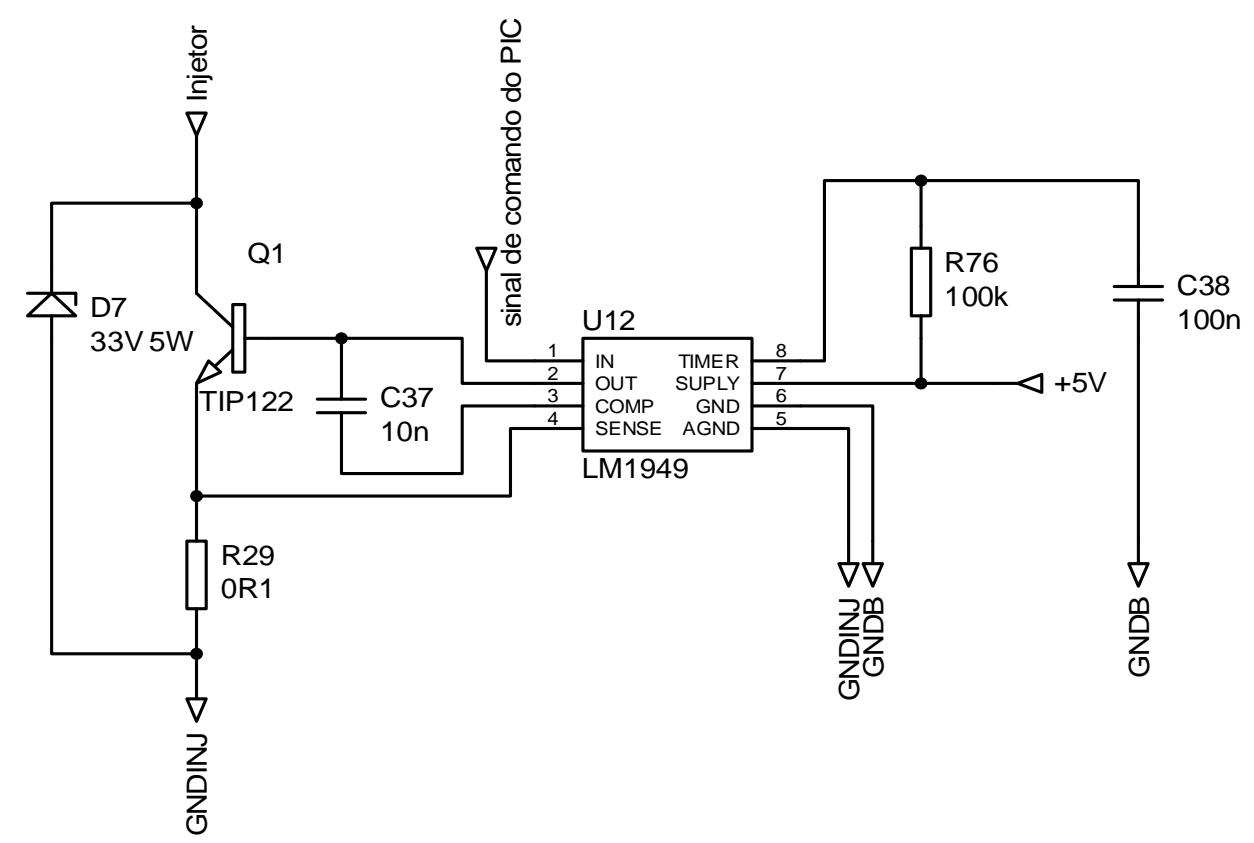

Figura 42 - Circuito de comando das válvulas injetoras

Ainda no bloco de sincronismo é possível observar que as portas RC3, RC4 e RC5 foram dedicadas à comunicação SPI que é feita com o microcontrolador de gerenciamento. Para projetos futuros, foram alocadas as portas RC6 e RC7 como pinos de comunicação USART.

Outras portas que foram utilizadas nesse bloco foram: RB0 que recebe o sinal do sensor de rotação condicionado; RA4 que recebe o sinal da linha 15; RB4 e RB5 utilizadas com LEDs de indicação diversas; RB6 e RB7, fazendo parte do circuito de gravação no microcontrolador e por fim, algumas outras portas foram disponibilizadas como pinos reservas e que podem ser identificadas na figura 41 pelo símbolo " $<-$ " na entrada de cada pino do microcontrolador.

\subsubsection{Alterações Realizadas na Segunda Versão do Hardware de Sincronismo}

Com a substituição da primeira versão para a segunda versão do hardware, o bloco de sincronismo sofreu poucas variações. A principal delas foi a introdução do 
CI MC 33810 como interface entre o microcontrolador e o comando das válvulas injetoras e bobinas de ignição. Esse circuito de interface foi escolhido, pois além de ser capaz de comandar as válvulas injetoras diretamente, sem o circuito de interface da figura 42, reduzindo o tamanho da placa de circuito impresso, ele tem a função de diagnosticar o sistema de ignição, conseguindo retornar para o microcontrolador de sincronismo o status desse sistema com informações como: corrente nominal (pino NOMI), corrente máxima (pino MAXI) e duração da centelha (pino SPKDUR) (FREESCALE, 2011).

$\mathrm{Na}$ verdade, esse circuito de interface tem toda sua configuração feita pelo bloco de gerenciamento pelos pinos SDI, SCLK, OUTEN, CS e SDO, além dos pinos SPKDUR, NOMI e MAXI que são utilizados para efeito de diagnóstico do sistema de ignição. Somente é função do microcontrolador de sincronismo comandar as entradas GN0, GN1, GN2, GN3, GD0 e GD1 que são respectivamente responsáveis por atuar as válvulas injetoras um, dois, três e quatro e nas bobinas de ignição um e dois. O diagrama de funcionamento do MC 33810 pode ser visualizado na figura 43.

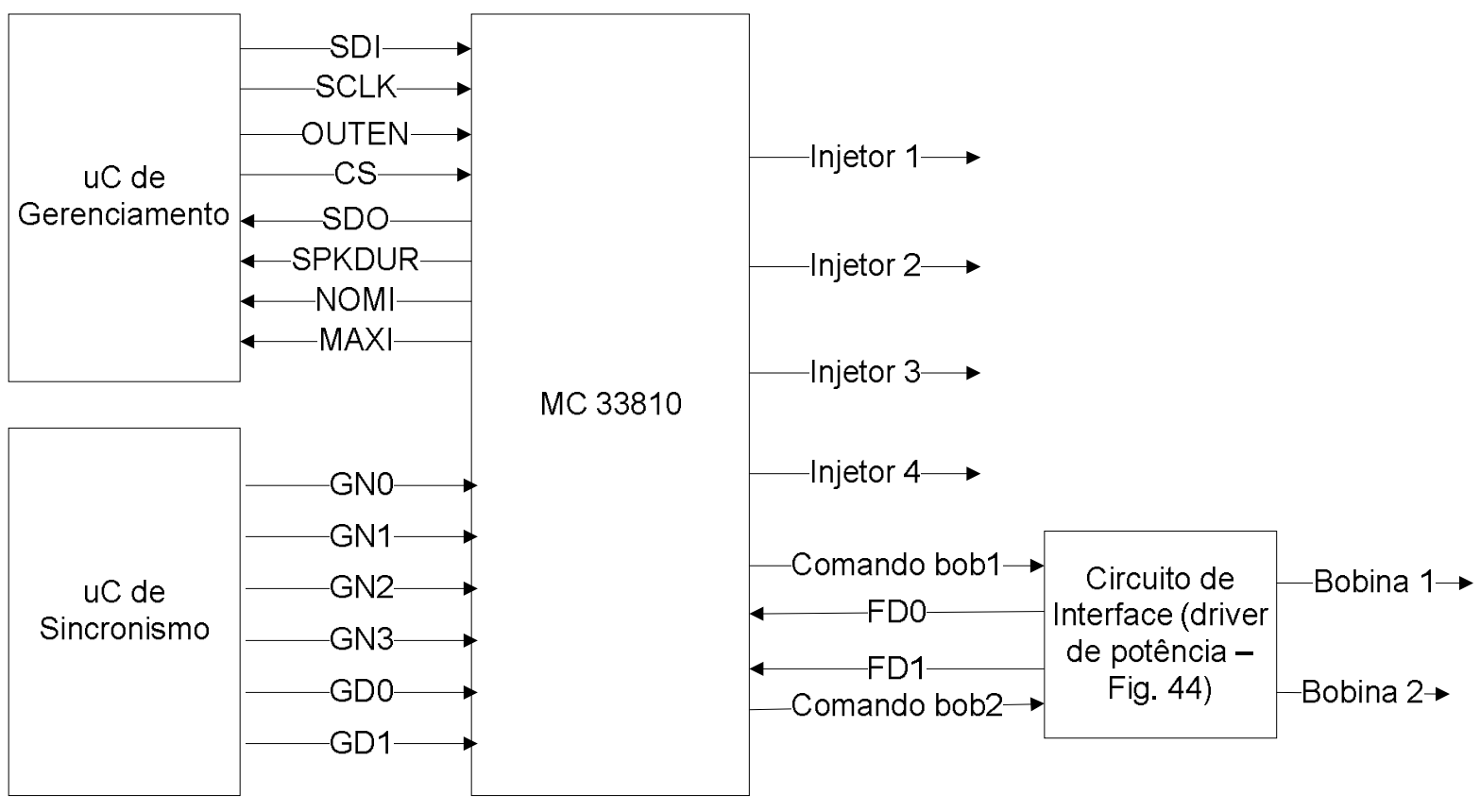

Figura 43 - Diagrama de funcionamento do circuito de interface MC 33810.

Como o MC33810 não possui potência suficiente para acionar as bobinas de ignição foi utilizado para isso o transistor IGBT (IRGS14C40L) que recebe um sinal em sua base acionando a bobina que está conectada no coletor. Há ainda nesse circuito um sinal de feedback (FD0) utilizado pelo MC33810 para processar os sinais de realimentação para colher uma amostra da corrente de carga e monitorar o seu 
valor a título de diagnosticar o sistema de ignição. Esse circuito pode ser observado na figura 44 a seguir:

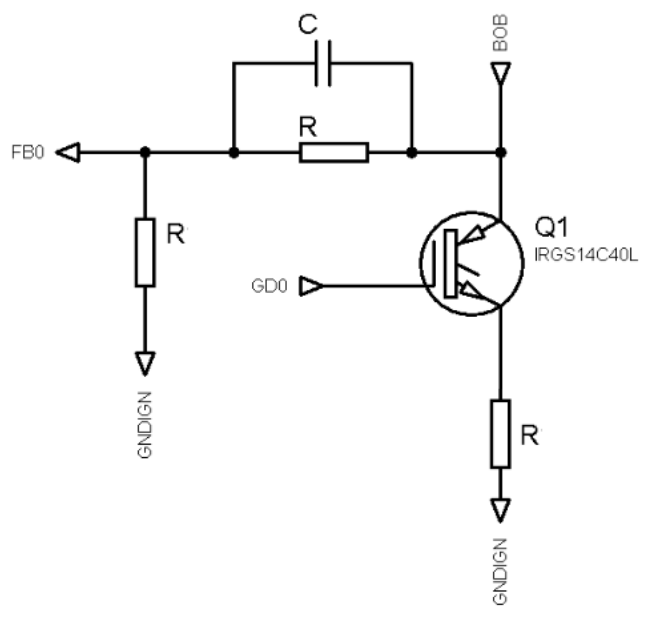

Figura 44 - Circuito de comando das bobinas de ignição.

\subsubsection{Bloco de Comunicação}

O bloco de comunicação e diagnose é constituído basicamente de um microcontrolador PIC18F452, um display de LCD conectado na porta D do microcontrolador e um circuito controlador CAN com o seu respectivo receiver. Assim como no bloco de sincronismo e gerenciamento, os pinos que não foram utilizados inicialmente foram disponibilizados como reservas para possíveis aplicações futuras (Figura 45). Esse bloco não sofreu alterações na segunda versão do hardware.

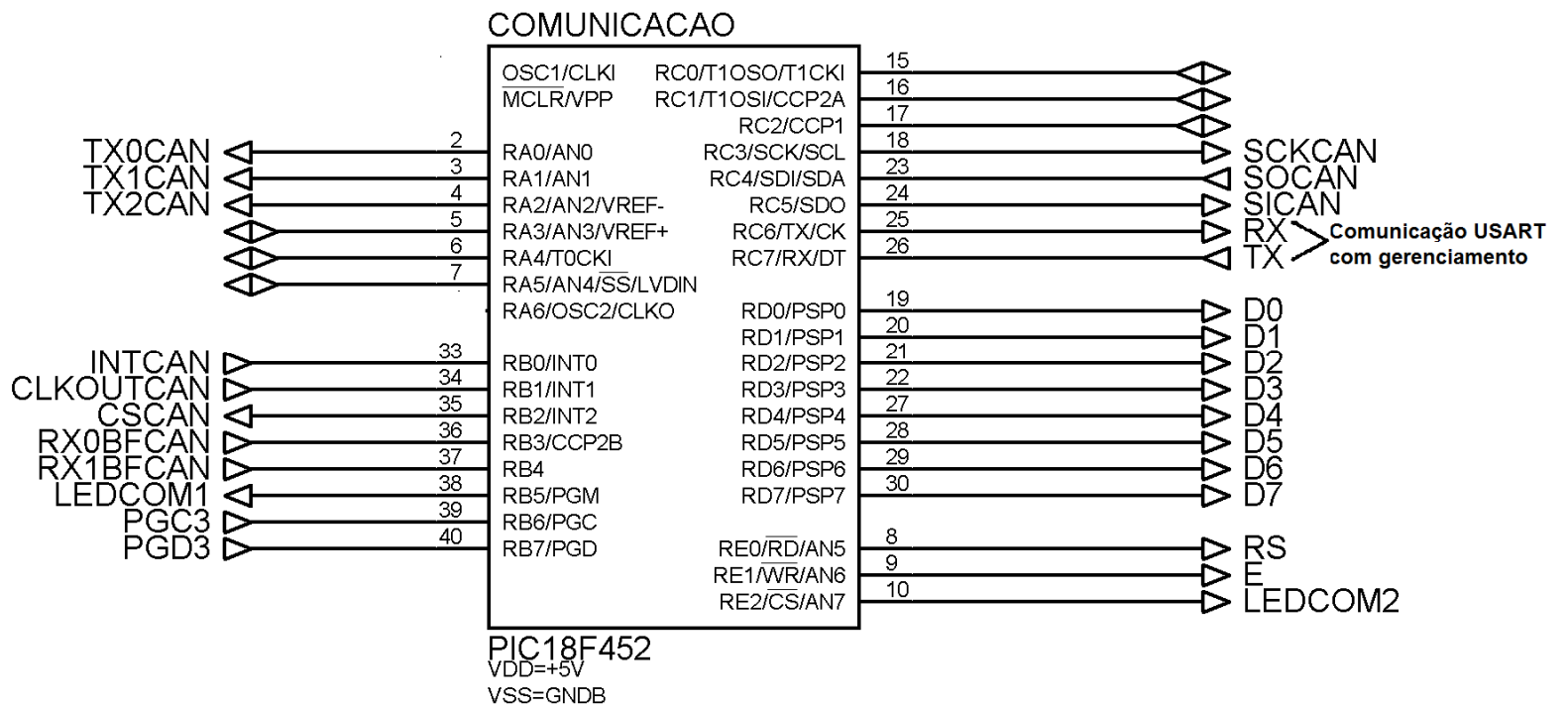

Figura 45 - Distribuição dos pinos no microcontrolador de Comunicação. 
Deve-se lembrar de que o leitor que necessitar de maiores informações sobre o hardware deste trabalho deve consultar o esquema elétrico disponibilizado no anexo $\mathrm{A}$.

\subsection{DESENVOLVIMENTO DO SOFTWARE}

A ECU desenvolvida é constituída por 03 blocos: gerenciamento, sincronismo e comunicação/diagnose (Figura 46). O primeiro bloco tem a função de identificar 0 regime vigente de operação do motor e estabelecer os parâmetros adequados para o comando dos atuadores, principalmente da válvula borboleta, sistema de ignição e injeção, a partir dos sinais provenientes dos diversos sensores. No caso da válvula borboleta o controle será realizado pelo próprio bloco de gerenciamento.

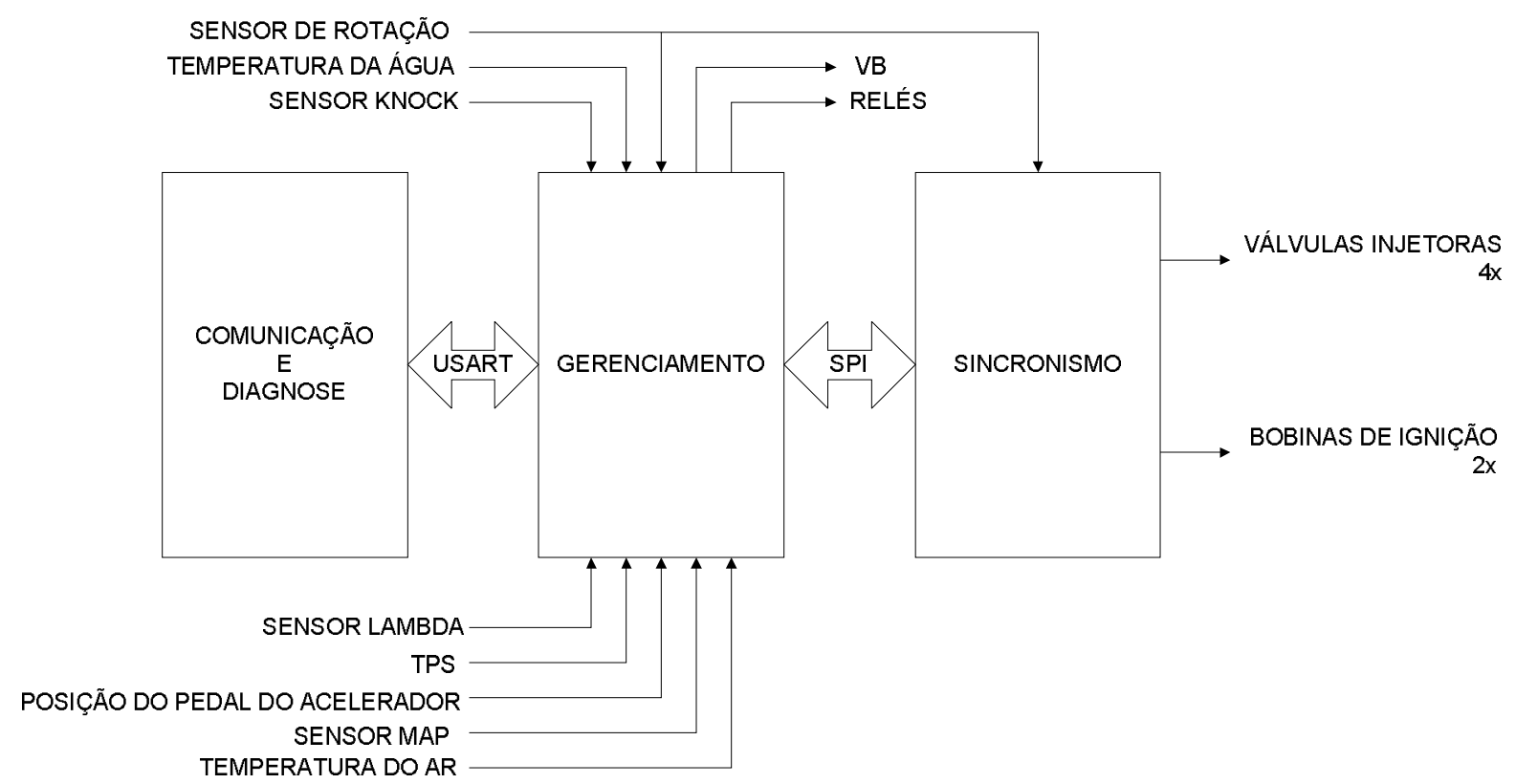

Figura 46. Diagrama em blocos do sistema.

O bloco de sincronismo irá receber as informações, via comunicação SPI do bloco de gerenciamento e tem a função produzir os pulsos sincronizados para os circuitos de interface das bobinas de ignição e das válvulas injetoras de combustível. O bloco de comunicação e diagnose receberá informações via comunicação USART do bloco de gerenciamento e terá a função de enviar informações para o conector de diagnose e disponibilizar informações (rotação e temperatura do motor, tempo de injeção etc) para o meio externo via LCD. Porém, como visto anteriormente o bloco de comunicação não será abordado nesse trabalho. Cada um destes blocos terá seu próprio microcontrolador com comunicação serial síncrona ou assíncrona entre eles. 
Nessa seção será descrito inicialmente a estratégia adotada para iniciar o desenvolvimento do programa, seguido das explicações dos programas gravados no microcontrolador de gerenciamento e sincronismo.

\subsubsection{Estratégia dos Programas}

Para iniciar o desenvolvimento dos softwares dos módulos de gerenciamento e sincronismo, inicialmente foi traçado um mapa de tempo dos dois módulos com a intenção de executar um estudo prévio do produto e saber quais seriam as funções básicas que deveriam ser executadas em cada momento de controle do motor. Esse mapa foi dividido em três fases, tendo sempre o comutador de ignição como referência: a primeira fase inicia-se no momento em que o comutador de ignição é acionado em posição de linha 15, seguido pelo acionamento da linha 50, prosseguindo para a última fase com o motor em funcionamento após a partida.

A carta de tempo construído para o bloco do programa de gerenciamento pode ser observado na figura 47.

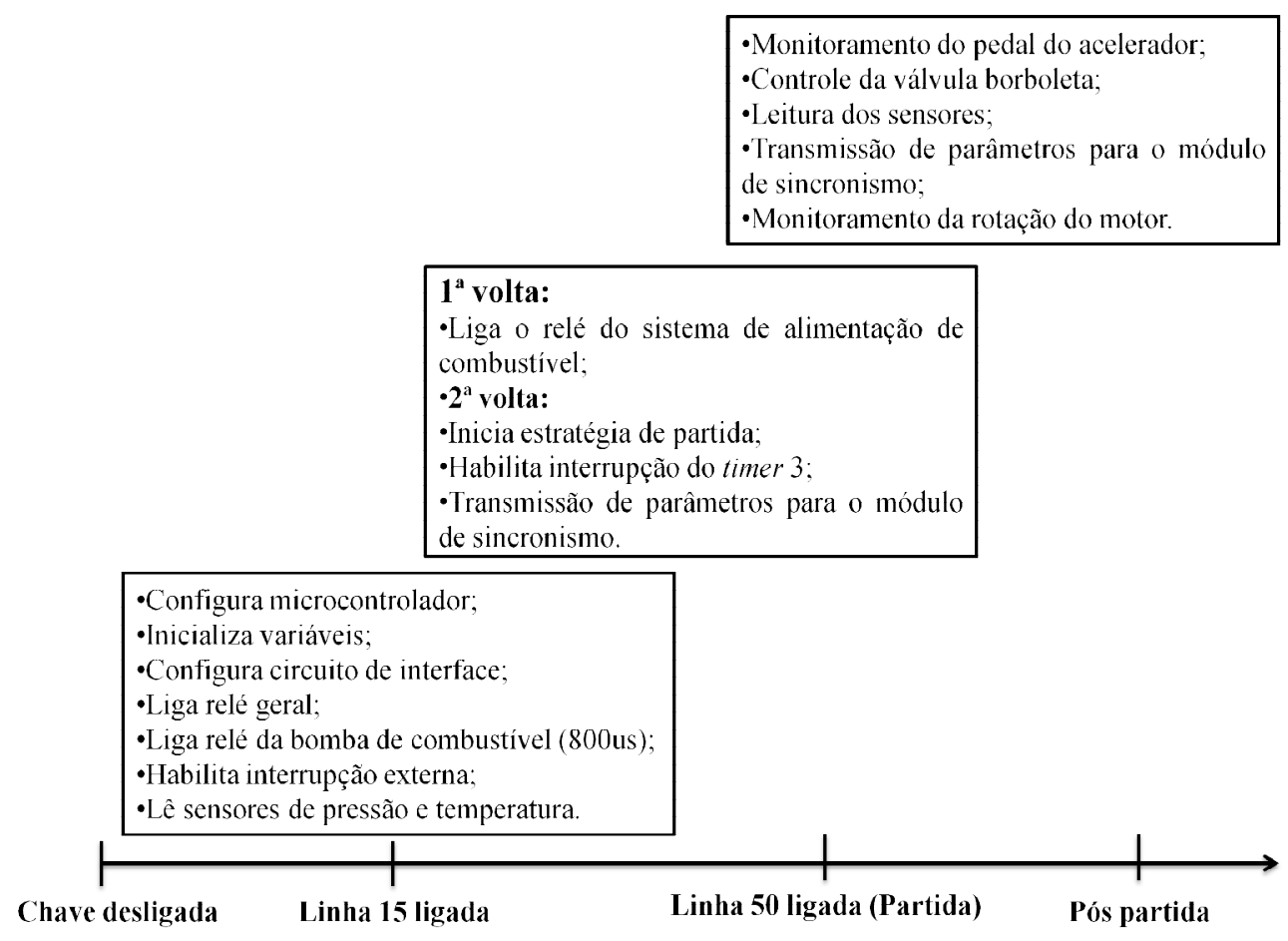

Figura 47 - Carta de tempos do módulo de gerenciamento.

Observa-se que inicialmente o programa de gerenciamento deverá executar algumas configurações internas do microcontrolador, seguido de iniciar as variáveis, determinando valores iniciais para elas, configurar os Cls de interface MC33972, 
MC33926 e MC33810, ligar o relé geral do motor, ligar o relé do sistema de alimentação de combustível para pressurizar a galeria de combustível, habilitar a interrupção externa, que detectará quando o motor iniciará o movimento e, por último executará a leitura dos sensores de pressão e temperatura para determinar um valor básico de tempo de injeção inicial.

Na segunda fase, o módulo de gerenciamento irá religar o relé de alimentação de combustível na primeira volta do motor com a intenção de manter uma pressão constante de combustível, seguindo com uma estratégia de partida que basicamente tem a função de atuar na válvula borboleta abrindo-a parcialmente. $\mathrm{Na}$ fase de partida, a interrupção do timer 3 será habilitada e os sensores serão lidos por intermédio dela, e alguns parâmetros serão transmitidos para o módulo de sincronismo para fornecer dados de atuação nos sistemas de injeção e ignição do motor.

Para manter o motor em funcionamento, na terceira fase o módulo de gerenciamento irá monitorar o pedal do acelerador e controlar a válvula borboleta em função do acionamento do mesmo.

Além disso, esse módulo continuará: monitorando todos os sensores do motor para calcular o melhor tempo de injeção e o ângulo de ignição, transmitindo os parâmetros para o sistema de sincronismo e monitorando a rotação do motor no intuito de manter o motor em marcha lenta, ou acionar estratégias de segurança (por exemplo: desligar bomba de combustível) caso o motor pare de funcionar involuntariamente.

Paralelamente ao módulo de gerenciamento está em funcionamento o módulo de sincronismo, cujo mapa de tempo pode ser observado na figura 48.

Inicialmente o programa de sincronismo executa algumas configurações internas do microcontrolador, seguido de iniciar as variáveis, determinando valores iniciais para elas e habilitar a interrupção externa que detectará quando o motor iniciará o movimento.

Na primeira volta do motor, o módulo de sincronismo não executa função alguma, pois somente espera os parâmetros serem transmitidos pelo módulo de gerenciamento. Somente na segunda volta o módulo de sincronismo recebe os parâmetros, onde a partir de então com a ajuda das interrupções internas e externas do microcontrolador o módulo de sincronismo atua sincronizando os sistemas de injeção de combustível e ignição do motor. 


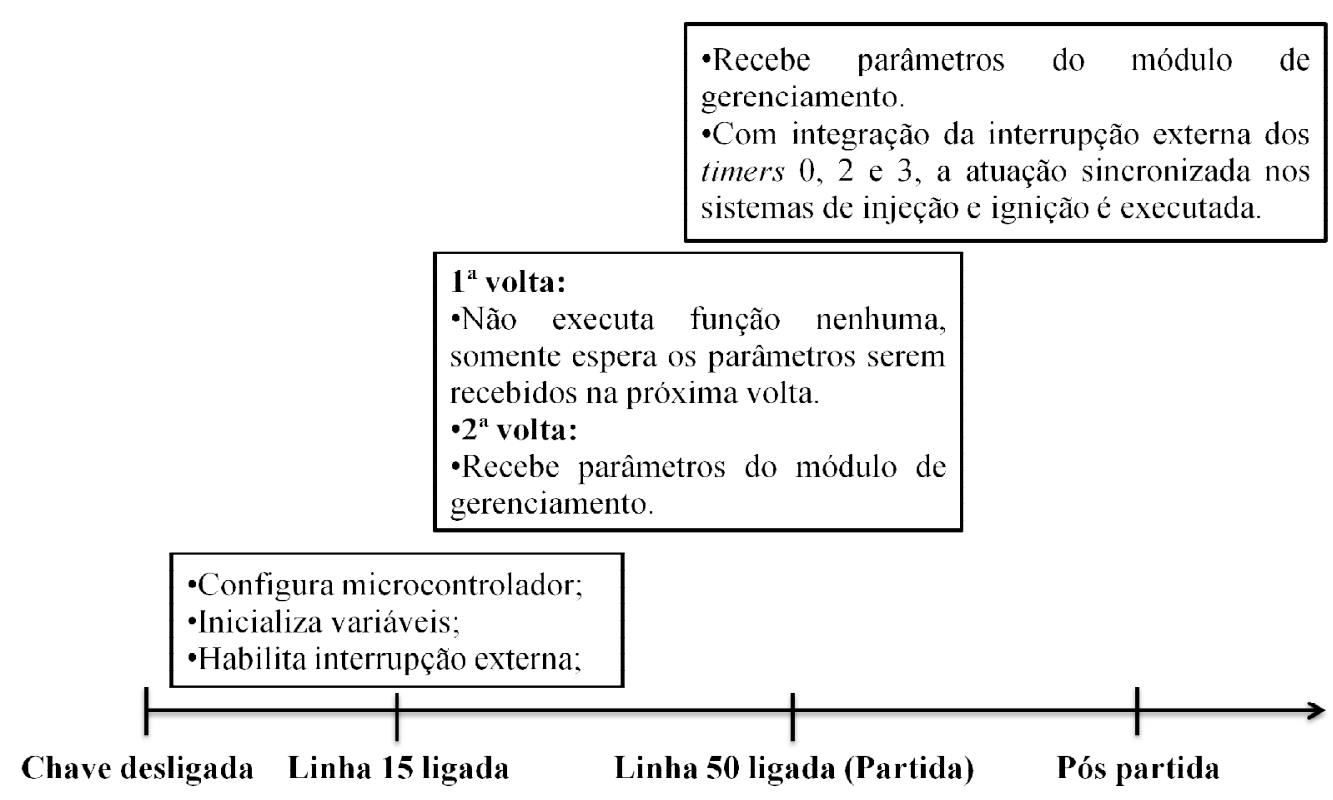

Figura 48- Carta de tempos do módulo de sincronismo.

\subsubsection{Descrição do Software de Gerenciamento}

O programa principal do sistema de gerenciamento é iniciado no momento em que o hardware for alimentado, e o fluxograma pode ser visualizado na figura 49. Primeiramente, são feitas as configurações dos hardwares: microcontrolador (timers, canais analógicos, portas de entradas e saídas etc), circuito de interface das válvulas injetoras e bobinas de ignição (MC33810) e multiplexador MC33972. Seguido dos carregamentos dos valores iniciais de cada variável.

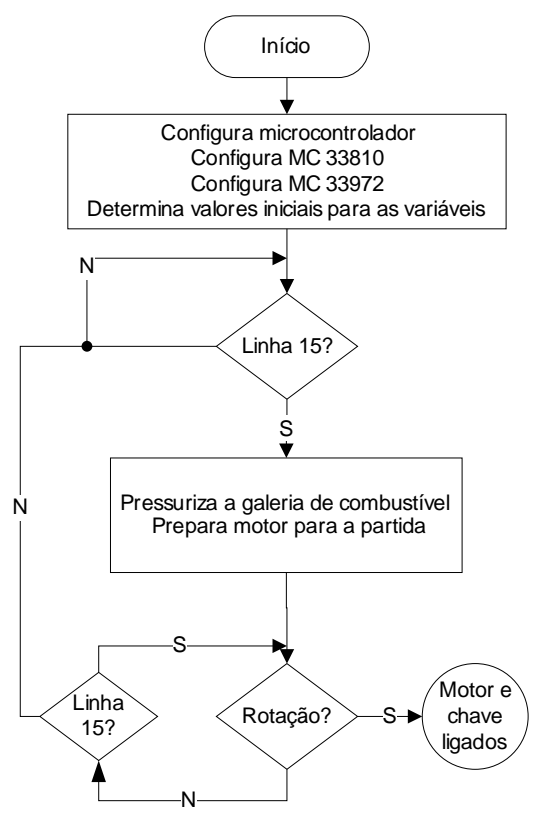

Figura 49 - Fluxograma da primeira fase do programa. 
Após essas primeiras configurações o programa principal fica em um looping esperando que a linha 15 seja ativada, ou seja, que a chave de ignição seja ligada.

Quando isso acontece, a galeria de combustível é pressurizada e valores como pressão atmosférica, detectada pelo sensor MAP com o motor desligado, temperatura do ar de admissão e temperatura do líquido de arrefecimento são lidos para determinar os parâmetros iniciais para a partida.

Parâmetros esses, tais como: posição da válvula borboleta, tempo de injeção, momento de disparo da centelha no sistema de ignição, momento de disparo do pulso de abertura das válvulas injetoras e acionamento do borne negativo da bobina de comando do relé de partida.

Determinados os parâmetros, o programa se mantém em um looping esperando que haja rotação no motor, ou seja, que a chave de ignição acione a linha 50 do comutador de ignição. Esse sinal está conectado no lado positivo da bobina de comando do relé de partida, que quando acionado envia um sinal para o bendix do motor de partida que por sua vez acopla o motor de partida ao volante do motor iniciando o movimento rotativo na árvore de manivelas.

O sinal de rotação do motor entra no microcontrolador no pino RB0, que foi configurado como uma interrupção externa. Dessa forma, no primeiro pulso do sinal de rotação o programa identifica que o motor começou a girar e então entra em uma segunda fase do programa inicial chamado de "motor" e "chave ligados" (figura 50).

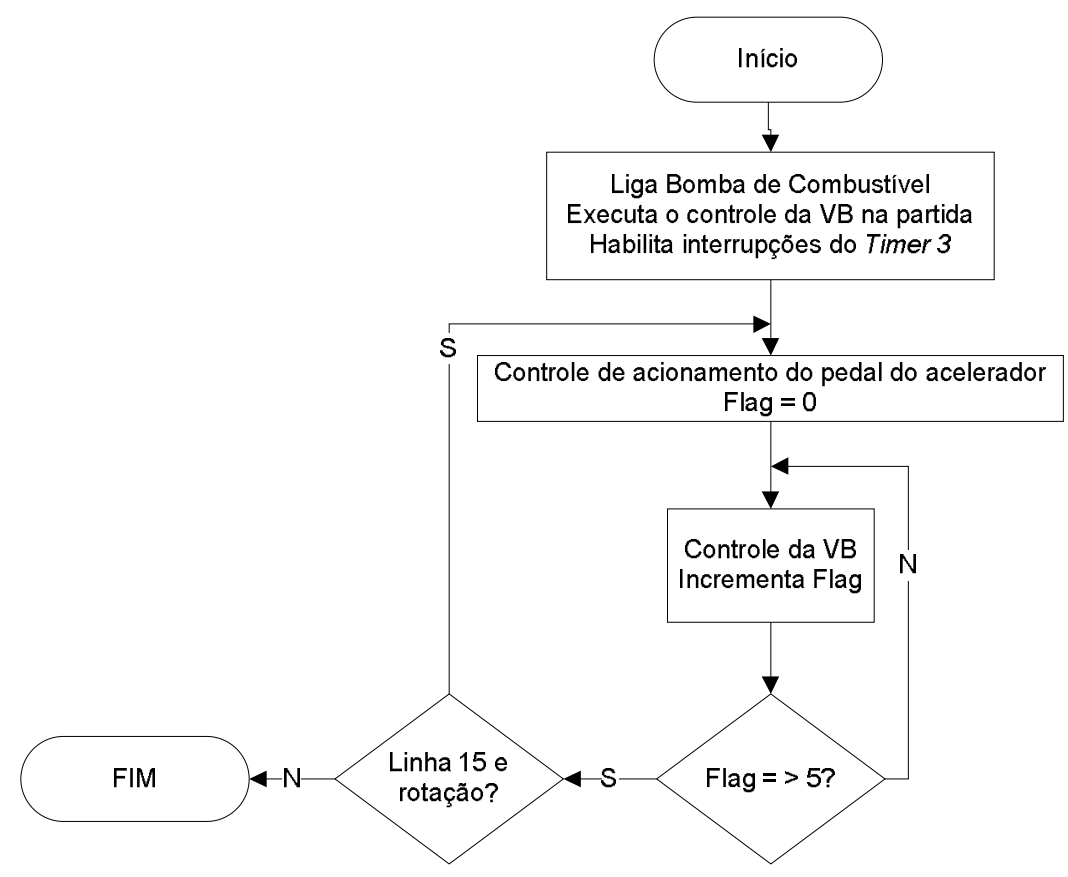

Figura 50 - Fluxograma da segunda fase do programa principal de gerenciamento. 
Ao detectar a rotação, o programa entra em um estágio onde a chave de ignição está ligada, e o motor está funcionando com o torque exercido pelo motor de partida, forçando o gerenciamento a acionar o relé da bomba de combustível para pressurizar novamente a galeria de combustível.

Para garantir que o motor continue em funcionamento, foi adotada uma estratégia onde a válvula borboleta se abre parcialmente durante aproximadamente $200 \mu$ s para permitir uma maior passagem de ar para dentro dos cilindros, pois diante disso é possível também injetar uma quantidade mássica maior de combustível, aumentando a força de combustão no motor no momento da partida, cessando então a utilização do motor de partida.

Porém o momento adequado para que essa abertura ocorra é alguns milissegundos antes do início da injeção de combustível, ou seja, quando a árvore de manivelas está se aproximando da falha da roda geradora de impulsos, aproximadamente na posição de dente 56.

Com a rotação do motor em ascendência, o microcontrolador sai da função de "controle_partida" deixando a válvula borboleta na posição ideal para funcionamento do motor no regime de marcha lenta ou aquecimento. Nesse momento, a interrupção do timer 3 é habilitada e inicia-se um looping, onde o programa se manterá até que a linha 15 seja desativada ou a rotação do motor cair à zero. A função do timer 3 no programa é executar a leitura dos sensores a cada interrupção.

Nesse laço do programa, é feito o controle de acionamento do pedal do acelerador através da função "controle_rpm_pedal" e com isso é calculado a posição desejada da válvula borboleta. Esse valor alimenta a função "controle_vb", que tem a função de atuar na válvula borboleta e fazer o controle da posição da mesma referenciando-se pelo valor calculado na função anterior. Essa função é executada cinco vezes e depois o programa é liberado para seguir adiante. Isso só ocorre por motivos de segurança, evitando o travamento dentro dessa função, pois caso o programa se mantivesse nela até que a válvula borboleta alcançasse a posição desejada, em caso de defeito no TPS, por exemplo, o programa ficaria travado. 


\subsubsection{Interrupção do Timer 1}

O timer 1 no software de gerenciamento executa duas funções: uma como contador e outra através da interrupção por estouro na contagem interna de seu contador. A função de contador foi utilizada na função de interrupção externa (próxima subseção) para determinar qual é o valor do período no intervalo dos pulsos do sensor de rotação. A interrupção ocorrerá quando o intervalo entre dois pulsos do sinal de rotação tiver o período maior que aproximadamente $13 \mathrm{~ms}$ tempo esse que estoura a contagem interna do timer.

Essa interrupção é utilizada principalmente no momento da partida onde o sinal do sensor de rotação é muito instável e não confiável. Com isso minimiza-se o risco de identificar a falha de dois dentes da roda fônica no momento errado e de repente perder totalmente o sincronismo do sistema de injeção e ignição com a posição angular da árvore de manivelas

O que acontece é que quando o timer 1 estoura e gera uma interrupção, a variável estouro é carregada com o valor 1. Essa variável tem o objetivo de na função interrupção externa informar se houve um período muito longo entre dois pulsos, pois caso isso seja verdadeiro a variável dente é reiniciada, inibindo dessa forma o acionamento das válvulas injetoras e bobinas de ignição. Isso é mais um sistema de segurança para que não haja um acionamento desses sistemas em um momento errôneo, evitando a fadiga ou quebra de algum componente do motor.

\subsubsection{Interrupção Externa}

A interrupção externa é uma interrupção gerada por meio de um evento externo que independa do clock do microcontrolador. Nesse projeto a fonte dessa interrupção tem sua origem no sinal condicionado do sensor de rotação do motor, e tem como principal função medir o período entre dois dentes do sinal retangular gerado pelo condicionador do sensor de relutância magnética.

Por isso, esse sinal tem sua entrada no pino RBO do microcontrolador. Com a medição do período entre os pulsos de cada sinal do sensor de rotação essa função é capaz de identificar o momento em que a falha de dois dentes da roda geradora de impulsos passa pelo sensor de relutância magnética, e dessa forma consegue 
sincronizar o funcionamento do programa com o funcionamento do motor. Além disso, a interrupção externa abrange a função de enviar sincronizadamente os parâmetros calculados pelo gerenciamento (tempo de injeção, avanço de ignição etc) via comunicação SPI para o microcontrolador de sincronismo. Esta última tarefa faz parte da função "conta_dente".

Com os testes executados no andamento do projeto, foi identificada a necessidade de aplicar um filtro via software no sinal do sensor de rotação, pois foi observado nesse sinal pulsos de ruídos. Porém, esses pulsos eram confundidos com sinais provenientes do sensor de rotação, diminuindo dessa forma a precisão da leitura do sinal e prejudicando a funcionalidade do software. Com isso, para conseguir uma confiabilidade maior do software, a interrupção externa agregou ainda a função de filtro.

A figura 51 mostra um oscilograma com dois sinais: o primeiro, em amarelo, é o sinal do sensor de relutância magnética sem condicionamento nenhum e o segundo, em verde, é o sinal de rotação do motor após o condicionamento pelo LM1815. É possível observar nos dois sinais um ruído que está evidenciado pelo círculo vermelho em volta deles.

Agilent Technologies

TUE SEP 13 21:20:28 2011

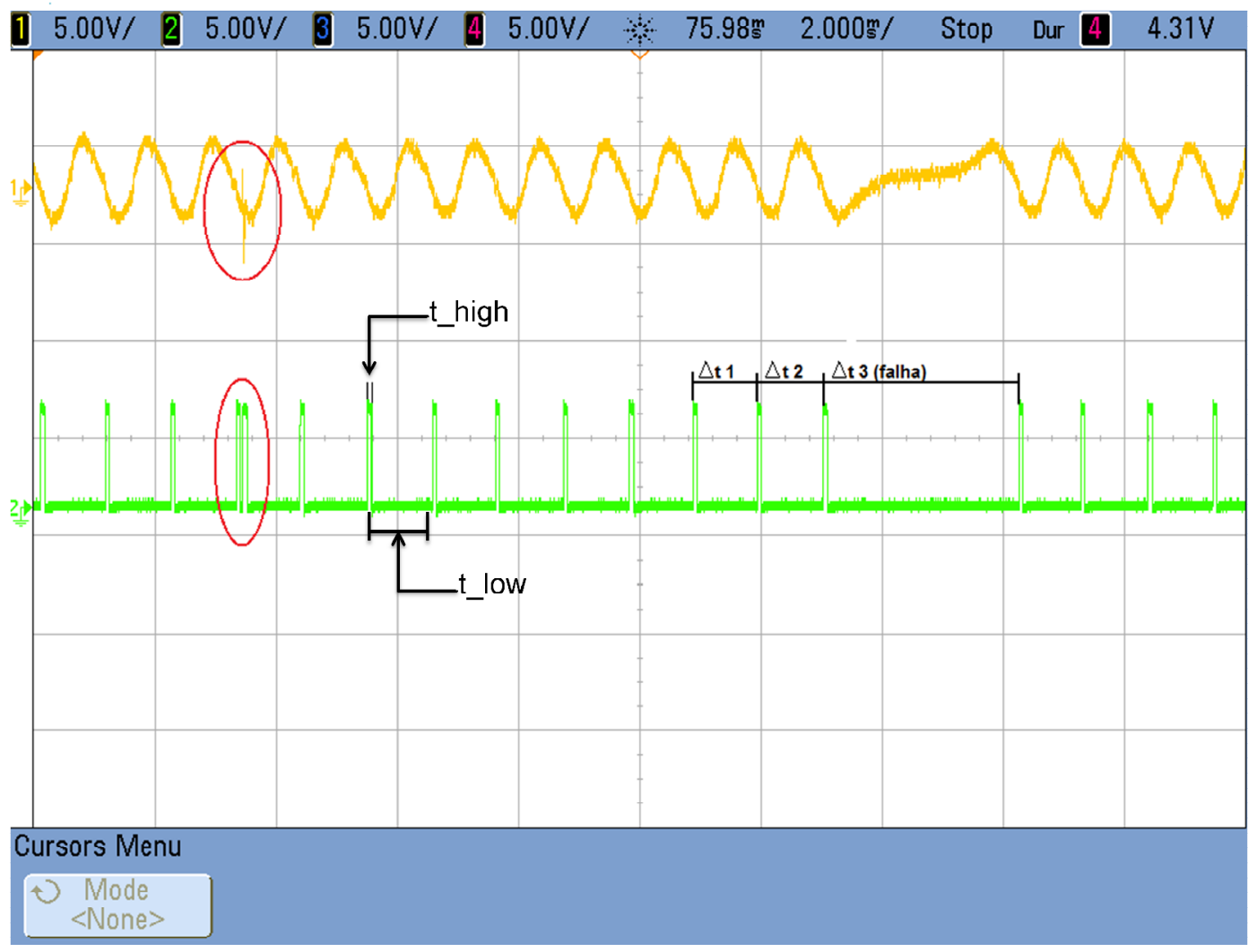

Figura 51 - Ruído no sinal de rotação. 
Esse ruído tem um período máximo de aproximadamente $10 \mu \mathrm{s}$ e considerando que o pulso do sinal de rotação foi ajustado para ter um período de $100 \mu \mathrm{s}$, é possível fazer um filtro via software para eliminá-lo, desprezando qualquer pulso que seja menor que $60 \mu$ s Foi escolhido esse valor, pois em testes práticos foram testados outros valores, e o de $60 \mu$ s foi o que obteve a melhor resposta. Por fim, para minimizar ainda mais esse ruído foi utilizado também um cabo blindado para conectar esse sinal da intersecção até o hardware da ECU desenvolvida.

O fluxograma da figura 52 mostra como todas as funções citadas acima: "identificação da falha", "filtro" e "conta_dente" trabalham dentro da interrupção externa.

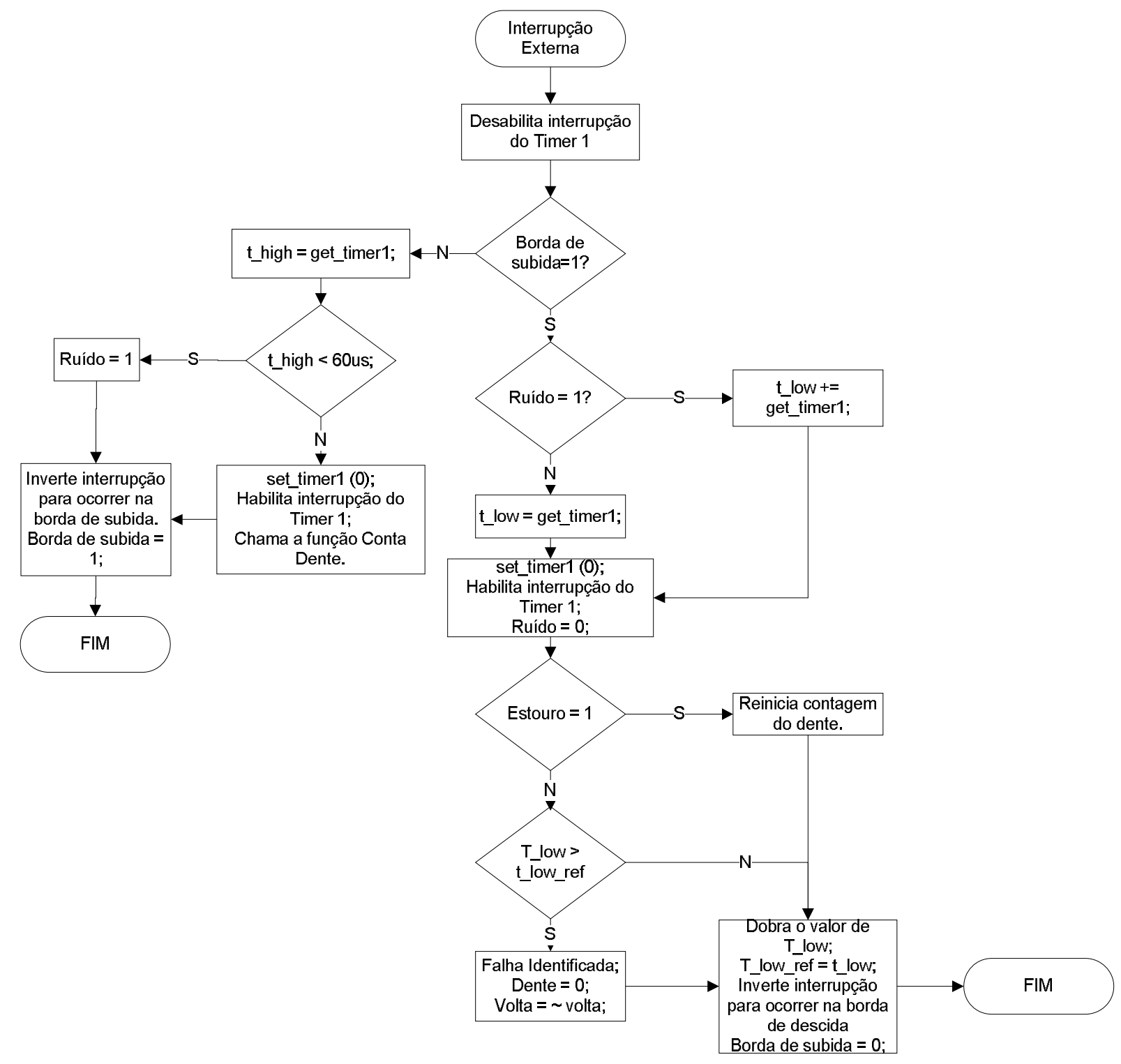

Figura 52 - Fluxograma da função interrupção externa. 
Após o inicio da interrupção externa a interrupção do timer 1 é desabilitada, para que ela não fique na fila de interrupções e ocorra após a interrupção externa. Procura-se saber se a interrupção foi gerada por uma borda de subida ou borda de descida do sinal, pois para cada condição será executado operações diferentes.

Caso seja uma interrupção derivada de uma borda de descida do sinal de rotação o tempo em que esse sinal se manteve em nível lógico "um" será armazenado na variável "t_high" (figura 51) e no próximo passo ele será comparado com o valor de $60 \mu \mathrm{s}$. Caso essa comparação comprove que o tempo armazenado é menor que $60 \mu \mathrm{s}$ significa que esse sinal na verdade é um ruído. Caso contrário significa que é um sinal proveniente do sensor de rotação do motor. Dessa forma o timer 1 é zerado, habilitado novamente e a função "conta dente" é executada. Por fim, a forma que se origina a interrupção externa é invertida, para que a próxima interrupção ocorra com uma borda de subida ao invés de descida.

Quando a próxima interrupção acontecer, ela será originada de uma borda de subida e então, após desabilitar a interrupção do timer 1, uma decisão é tomada dependendo se o sinal que gerou a interrupção anterior foi um ruído ou não. Se aquele sinal foi um ruído, o período do sinal em nível lógico zero é armazenado na variável "t_low" e somado com o valor que já estava armazenado anteriormente nessa mesma variável. Isso ocorre, pois quando o ruído surge, ele interrompe um sinal que teria somente um período em nível lógico zero, dividindo esse sinal em dois.

Portanto quando é identificado um ruído, o período do sinal que estava em nível lógico zero antes de acontecer o ruído é somado com o valor do período da continuidade daquele sinal após o ruído, resultando no valor total do período que aquele sinal ficou em nível lógico zero, desprezando o tempo em que o ruído surgiu.

Após essa verificação o timer 1 é zerado, habilitado novamente e é seguido da condição que checa a variável "estouro", determinando se o período entre dois dentes foi maior que $13 \mathrm{~ms}$ como visto na descrição do timer 1 . Caso essa variável "estouro" esteja carregada com o valor "um" significa que o timer 1 estourou, portanto é reiniciada a contagem dos dentes, o valor que está armazenado em $t$ _low é dobrado e armazenado em uma variável chamada de t_low_ref, que será usada para comparações na identificação da falha. Por fim, a forma que se origina a interrupção é invertida, para que a próxima interrupção ocorra novamente com uma borda de descida. 
Se a variável "estouro" estiver carregada com o valor zero significa que o valor do período entre os pulsos do sinal de rotação é plausível. Assim, o próximo passo é fazer a comparação entre o valor do período entre dois pulsos atual, $\Delta t 2$, por exemplo, (figura 51), e um período anterior entre dois pulsos, $\Delta \mathrm{t} 1$, que foi dobrado. Essa comparação é feita para identificar se aquele período refere-se a uma passagem de dente sequencial da roda fônica, ou se refere à passagem do perímetro de falha dos dois dentes da mesma $(\Delta t 3)$. Se o período atual for maior que duas vezes o período anterior significa que aquele tempo que o sinal de rotação ficou em nível lógico zero é o sinal da falha da roda fônica. Isso pode ser observado comparando-se o sinal $\Delta \mathrm{t} 3 \mathrm{com}$ o sinal $\Delta \mathrm{t} 2$. Nesse caso o período $\Delta \mathrm{t} 3$ é maior que o dobro de $\Delta \mathrm{t} 2$, consequentemente o programa identifica ele como um sinal de falha dos dentes da roda fônica.

Dessa forma a falha é identificada, a contagem de dentes é reiniciada, a variável volta é invertida, o valor que está armazenado em $t$ _low é dobrado, armazenado na variável $t$ llow_ref e inverte-se a origem de interrupção para borda de descida.

\subsubsection{Função Conta Dente}

A sub-rotina "conta dente" tem a função de incrementar a variável "dente", a cada vez que é executada, limitando 58 como valor máximo (número de dentes da roda fônica) e zerando essa variável sempre que ela atingir esse valor. Dessa forma é possível aumentar a confiabilidade juntamente com a identificação da falha, da obtenção do sincronismo de todo o programa, pois essa variável indica qual é a posição angular da árvore de manivelas no motor.

Isso é importante, pois algumas ocorrências dependem da posição exata da árvore de manivelas para acontecer.

Dentro dessa sub-rotina são executadas funções como: habilitar a interrupção do timer 0 , tendo a função de determinar a rotação do motor, calcular o tempo de injeção e enviar os parâmetros para o microcontrolador de sincronismo. Os parâmetros que são enviados via SPI para o sincronismo são: dente que deve ser disparado o pulso de ignição (dente_ign), o tempo depois da passagem do dente que deve ser disparado o pulso de ignição (ig_tmr2_disparo) - com essas duas variáveis, o avanço de ignição é determinado -, o tempo de carregamento da bobina 
(t_carregamento), dentes que devem ser iniciada a contagem de tempo para que sejam disparados os pulsos de injeção (ij_dente_1 e ij_dente_2), o tempo depois da passagem do dente que deve ser disparado os pulsos de injeção (ij_14_tmr3_disparo e ij_23_tmr3_disparo), o modo de injeção (modo_inj) e o tempo de injeção (tempo_inj). Essas variáveis serão melhores descritas na seção de sincronismo.

A ordem de acontecimento dos eventos dentro da função "conta dente" pode ser observada na figura 53.

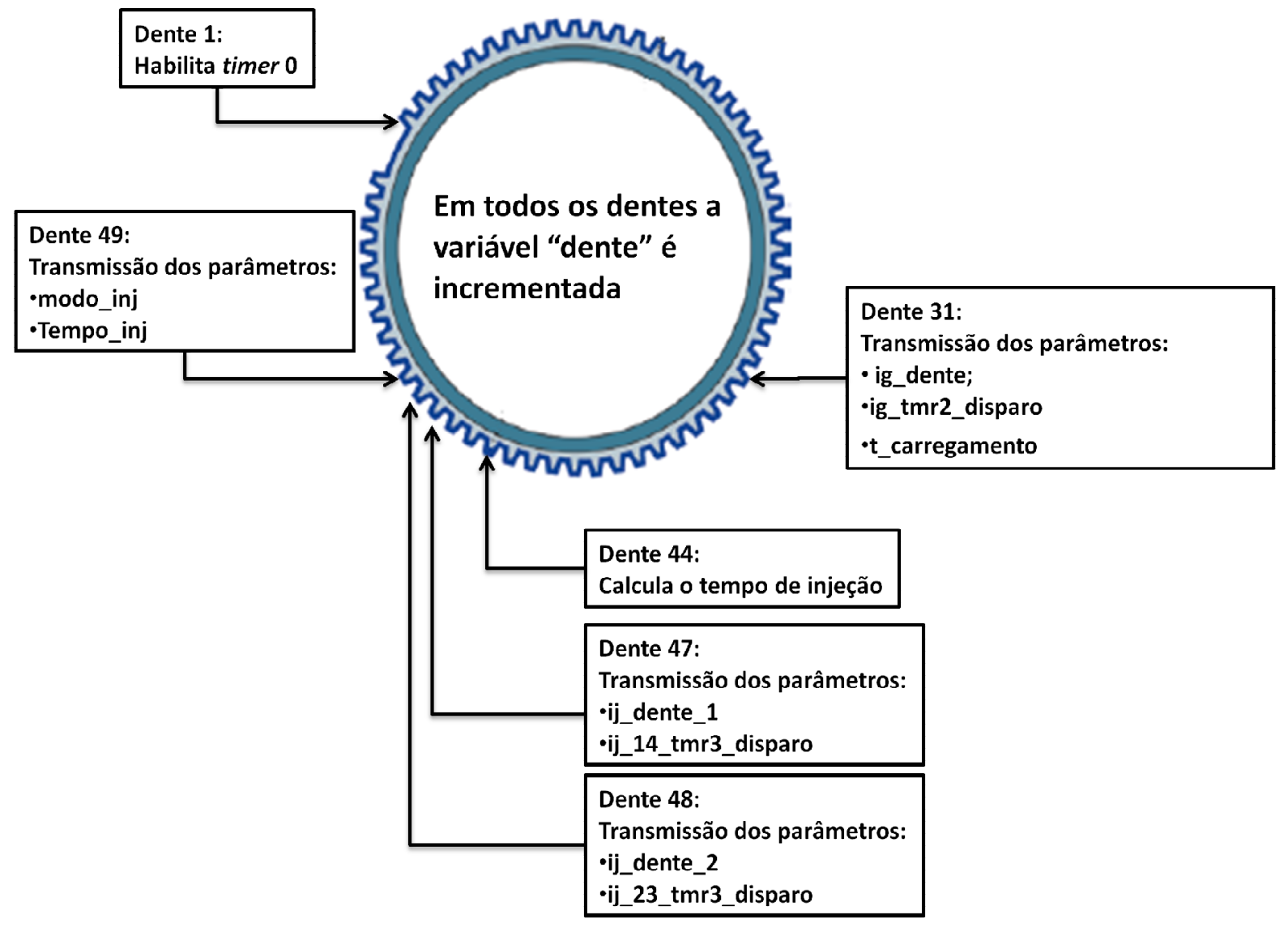

Figura 53 - Sequência de eventos na função conta dente.

O momento de acontecimento desses eventos principalmente as transmissões de parâmetros foram determinados de acordo com os espaços livres do programa de sincronismo. Dessa forma quando o programa de sincronismo não está executando nenhuma função ele receberá os dados sem interferir em qualquer operação que ele esteja executando, protegendo o programa de mais de uma interrupção acontecer o mesmo tempo. Uma vez que a cada transmissão SPI ocorre uma interrupção no programa de sincronismo.

O tempo de injeção é calculado de acordo com os valores de pressão e temperatura do ar admitido, posição do pedal de acelerador, temperatura do líquido 
de arrefecimento e de uma variável "erro", que é calculada pela subtração da posição desejável da válvula borboleta (calculada pela posição do pedal do acelerador) e posição atual da válvula borboleta, assim como mostra cópia de parte do programa abaixo.

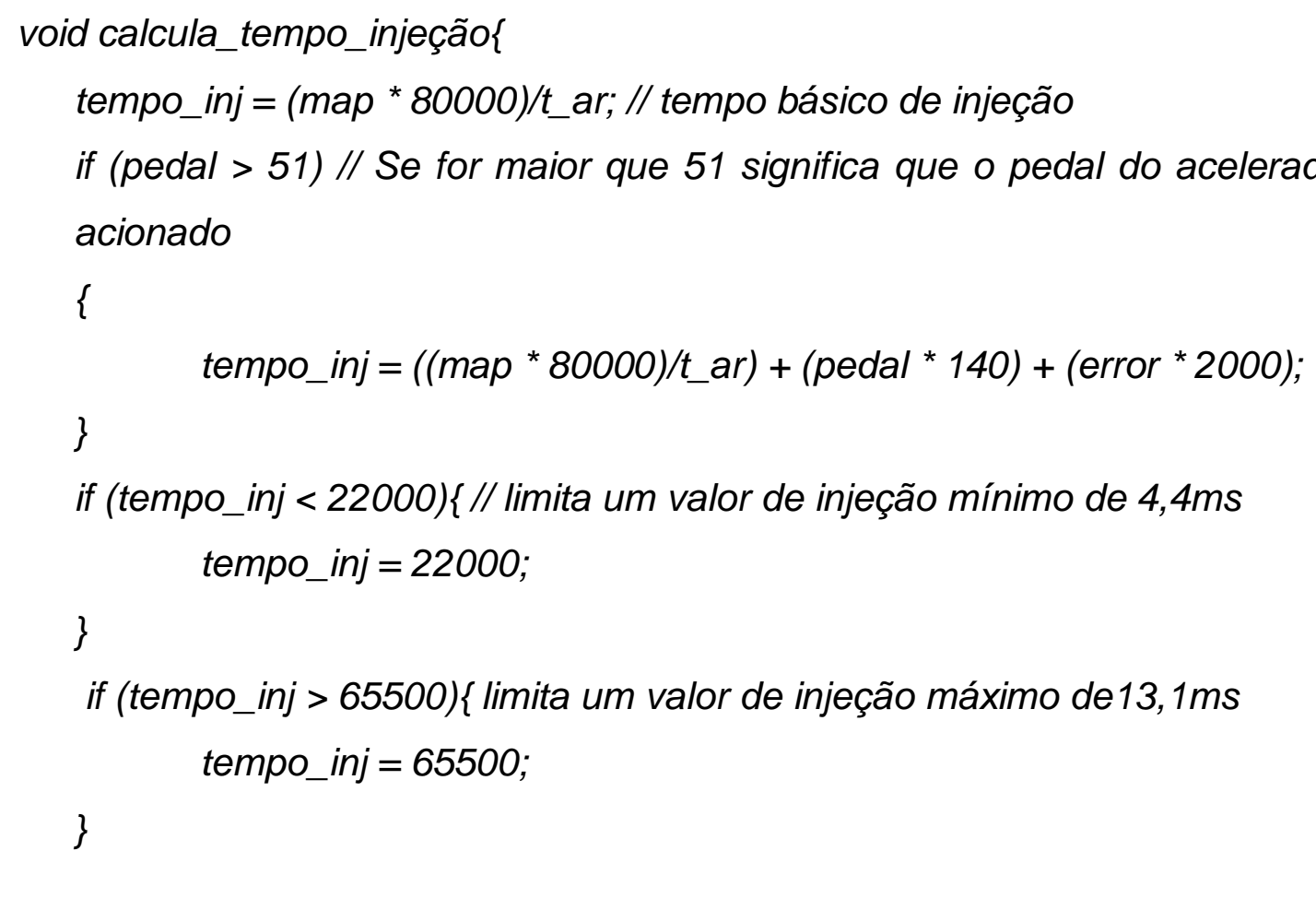

Todas as constantes determinadas nos cálculos acima foram calculadas primeiramente pelas equações 1, 2, 4 e 6, e ajustadas com testes práticos de calibração para uma melhor resposta do funcionamento do motor para os diversos regimes do mesmo.

Como o limite de contagem dos timers do PIC18F452 limitam-se a 65536 um limite superior para o valor de injeção de combustível de 65500 foi adotado. Já como limite inferior foi adotado o valor de confiabilidade igual a 22000, representando esse valor um tempo de injeção de $4 \mathrm{~ms}$. Esse valor foi aplicado, pois em testes práticos notou-se que um valor de injeção inferior a $4 \mathrm{~ms}$ reduzia a eficiência do motor.

\subsubsection{Interrupção do Timer 0}

A interrupção do timer zero é habilitada pela sub-rotina "conta dente", tendo o contador iniciando a contagem do valor 15536, pois é esse valor quem vai garantir uma identificação da rotação do motor. Como esse timer é composto por 16 bits, ele 
tem a capacidade de contar até 65536, e após isso o contador estoura e a interrupção é gerada. Portanto pode-se afirmar que esse contador irá contar 50000 vezes antes de estourar. Como esse timer foi dividido por 1 na configuração inicial, o período de cada contagem do contador é de $0,2 \mu \mathrm{s}$, totalizando uma contagem de 10 ms antes do estouro do mesmo.

O timer 0 do programa de gerenciamento tem a função de determinar a rotação e a fase do motor, o modo de injeção adequado para cada regime de funcionamento do motor e buscar na memória de programas do PIC os parâmetros a serem transmitidos para o sincronismo (Figura 54).

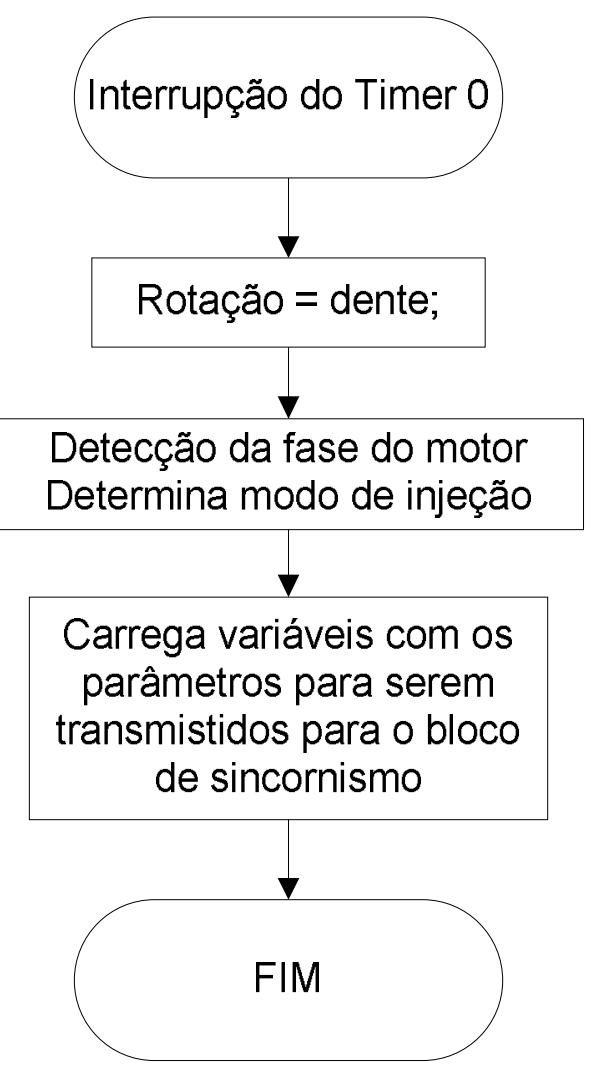

Figura 54 - Fluxograma da função de interrupção do Timer 0.

A resolução da rotação é de 100 rpm, uma vez que a unidade de milhar e a centena da variável rotação são determinadas pela variável dente, cujo incremento é unitário, como foi visto na subseção anterior. A contagem dos dentes inicia-se logo após a identificação da falha da roda fônica, quase simultaneamente com o disparo do timer 0 . Após $10 \mathrm{~ms}$ da identificação da falha o valor da quantidade de dentes da roda fônica que passa pelo sensor de rotação é igual a unidade de milhar e a centena do valor de rotação do motor. Um exemplo prático é que em 3000 rpm a quantidade de dentes que passam pelo sensor de rotação em 10 ms é igual a 30, 
sendo o número 3 referente a unidade de milhar e o zero a centena do valor de rotação do motor.

A vantagem da rotação ser determinada dessa forma é a simplicidade das operações, não exigindo muito tempo de processamento do microcontrolador com cálculos. Porém, a desvantagem é uma baixa resolução dessa variável, sendo possível medir a rotação somente a cada 100 rpm. Além disso, o limite de rotação que essa função pode medir é de 5800rpm, pois é a quantidade de dentes existentes na roda fônica. Lembrando que essa regra só é válida para motores que utilizam rodas fônicas com 60-2 dentes.

Detectar a fase do motor significa identificar qual é o momento de admissão e combustão de cada cilindro. Como o motor utilizado nesse projeto não tem um sensor para isso, o software desenvolvido teve que executar essa identificação. Porém, para os sinais de ignição foram adotados a estratégia de centelha perdida, ou seja, mesmo que o cilindro não esteja em fase de combustão quando o pistão estiver em movimento ascendente irá disparar a faísca no interior do cilindro. Portanto, a preocupação da detecção da fase foi exclusiva para o sistema de injeção.

Para detectar a fase do sistema de injeção foi adotada a estratégia de primeiramente fazer o motor entrar em funcionamento através do modo de injeção full group, mantendo-o até o motor atingir a rotação de 600rpm. Nesse momento o modo de injeção é alterado para banco-a-banco. Quando o motor atinge uma rotação superior a 1000 rpm o modo de injeção é alterado para sequencial e aleatoriamente é escolhido qual é o momento de admissão entre os cilindros 1 ou 4 e os cilindros 2 ou 3, monitorando na sequência a rotação do motor.

Caso a rotação do motor diminua, isso significa que a ordem de injeção escolhida estava errada. Dessa forma, o momento de admissão dos cilindros é invertido pelo software e a fase é identificada, mantendo-se a estratégia de injeção sequencial até que o motor seja desligado.

Os parâmetros de controle que são transmitidos para o sincronismo na função conta dente, são sempre atualizados na função de interrupção do timer 0. Esses valores são tabelados e gravados na memória de programa do PIC e são resgatados em função da rotação do motor. Portanto, cada tabela contém uma matriz com 60 valores, representando um valor para cada 100 rpm. 


\subsubsection{Interrupção do Timer 3.}

A interrupção do timer 3 é utilizada para executar a leitura dos sensores de posição do pedal do acelerador, MAP, posição da válvula borboleta e temperatura do líquido de arrefecimento a cada 105ms aproximadamente. Isso foi feito no intuito de minimizar leituras desnecessárias dos respectivos sensores, permitindo um controle maior dos acontecimentos de cada função dentro do programa.

Como visto anteriormente a segunda versão do hardware está equipada com um multiplexador que recebe os sinais de todos os sensores, e através de comandos do microcontrolador de gerenciamento seleciona qual será o sinal que sairá por seu pino de saída e entrará no pino RAO do microcontrolador. Esse comando do microcontrolador é feito através de uma comunicação SPI entre ele e o multiplexador onde através de um comando composto por 24 bits o multiplexador capta um sinal de entrada e transfere-o para a saída do mesmo de acordo com a combinação de bits que foi enviada para ele. Esses sinais de comandos que são enviados para o multiplexador pelo microcontrolador de gerenciamento foram todos baseados no data sheet do mesmo (FREESCALE, 2007).

Nessa porta RAO está contido um dos conversores analógicos digitais (A/D) do PIC18F452 utilizado nesse projeto. Esse conversor transforma uma tensão variável de entrada de 0 a 5 Volts em valores digitais que variam de 0 a 255.linearmente com a tensão de entrada.

Além de fazer a leitura dos sensores, o timer 3 ainda executa uma média do sinal da posição do pedal do acelerador e da posição da válvula borboleta para atenuar algumas interferências que possa existir no sinal. Em testes práticos foi observado que com essa média os resultados obtidos na atuação da válvula borboleta em função da posição do pedal do acelerador gerou uma menor vibração no controle da válvula borboleta que eram decorrentes de pequenas interferências no sinal desses dois sensores.

Para executar essa média, primeiramente o programa de interrupção do timer 3 realiza a leitura de todos os sinais dos sensores citados acima. Após isso, a leitura dos sensores de posição do pedal do acelerador e da válvula borboleta é realizada novamente. Com dois valores relacionados a mesma grandeza, uma média aritmética é realizada com eles no final da interrupção e os valores estão prontos 
para serem utilizados por outras funções do programa de gerenciamento, como por exemplo o controle da válvula borboleta.

\subsubsection{Controle PID da válvula Borboleta}

O controle da válvula borboleta é realizado pelo nó, na ECU em questão, de gerenciamento. Os sinais dos sensores de abertura da válvula borboleta e do acionamento do pedal de aceleração são coletados pelo multiplexador analógico MC33972 e são requisitados pelo PIC de gerenciamento através de comunicação via SPI. Os dados são requisitados um por vez, e em seguida, estratégia de controle PID é aplicada a.

O controle PID proporciona uma grande estabilidade na válvula, já que permite maior precisão do que um controle feito em malha aberta, sem a realimentação. $O$ controle deve ser relativamente preciso para que a válvula não vibre constantemente, podendo causar oscilações no movimento do veículo. O controle também possibilita grande velocidade no movimento da válvula e, desse modo, é possível posicioná-la em dada abertura de forma muito rápida.

O controle é feito através da leitura do potenciômetro do pedal, do potenciômetro da válvula borboleta e da aplicação de um PWM na válvula para que essa abra conforme solicitado. A ideia é ler o pedal e abrir a válvula conforme o pedal é pressionado. Como o motor irá operar sem carga, foi feita a opção de usar uma abertura mais branda da válvula borboleta. Isso faz com que mesmo com o pedal pressionado na posição máxima, a válvula não fique completamente aberta, esse fato, porém, não impede que o motor atinja rotações próximas de 6000 RPM, perto de seu limite de funcionamento.

Ao observar o comportamento da válvula borboleta da ECU original foi constatado que ela se comporta de maneira um pouco diferente da maneira desse trabalho. No caso o algoritmo implementado no trabalho funciona de forma semelhante a um cabo, quanto mais se pressiona o pedal mais a válvula abre. Quando funcionando com o controle da ECU original nota-se que a abertura se dá de forma que quando o pedal é solicitado de forma mais brusca a abertura é maior, assim o motor acelera mais rápido, quando solicitado mais suavemente o motor acelera mais devagar também. 
Nos testes do algoritmo de controle, o PID foi usado e calibrado através de observações da própria válvula. Foi observado o tempo de resposta e as oscilações, tentando minimizar ambos. Quando passado para o motor real foi observado que os sinais são muito ruidosos, isso atrapalhou o controle da válvula. As oscilações no motor foram muito maiores e mais frequentes do que nos testes realizados inicialmente em bancada. Portanto, os testes no motor foram iniciados primeiramente com o mesmo desligado e posteriormente os testes com o motor em funcionamento foram iniciados (SOARES e SACARPINETTI, 2012).

Como dito anteriormente, o ruído que aparece na leitura dos sensores de posição causa uma dificuldade em realizar o controle. Nesse caso a parcela diferencial do controle PID foi removida, sendo realizado um controle de posição PI. O controle PID sobre a válvula borboleta atua da seguinte forma:

- Parcela Proporcional:

Essa parcela do controle tem sua magnitude dependente do erro atual. No caso desse projeto, o erro é calculado como a diferença entre o valor do pedal e o valor da válvula borboleta. O pedal é acionado pelo usuário, impondo um valor para a válvula atingir. Desse modo, a posição da válvula é proporcional ao valor do pedal.

Neste caso específico, a válvula não precisa ser extremamente rápida, sendo que uma resposta na ordem de milissegundos já é o suficiente.

- Parcela Integral

No caso desse trabalho pode-se pensar em permitir que o erro da posição da válvula borboleta fique dentro de uma margem aceitável para as metas do projeto. Para ilustrar, no controle usado, tem-se o erro permitido de 2 unidades de conversão $\mathrm{A} / \mathrm{D}$, para mais e para menos. Como a válvula-borboleta abre 90 graus e a conversão A/D é de 8 bits (255 posições), a grosso modo, calcula-se que cada unidade da conversão A/D equivale a 90/255, ou 0,35 graus. Nesse caso o erro máximo permitido no controle usado no trabalho é de aproximadamente 0,7 graus.

Caso a parcela integrativa seja removida do sistema desse trabalho o erro estacionário se faz presente e de uma forma muito prejudicial: quando em marcha lenta a válvula borboleta deve permanecer mais fechada do que quando em repouso (posição da válvula desligada), ou seja, é preciso força-la para a posição fechada, caso contrário o motor acelera. Como o erro é relativamente pequeno entre a válvula estar em posição de repouso e estar fechada para posição de marcha lenta, se não 
houver a parcela integrativa o motor fica acelerado, sendo impossível alcançar a rotação em torno de 800rpm a 900rpm, valores recomendáveis para marcha lenta.

Do outro lado, pensando em um ganho muito grande para a parcela integrativa, o sistema pode responder mais rápido, porém o sobressinal é maior, demora mais tempo para estabilizar em uma determinada posição.

- Parcela Derivativa

A primeira vista parece ser uma parcela essencial para o controle do sistema em questão, porém, o problema da parcela diferencial é sua baixa imunidade a ruído. Isso fez com que se optasse por retirar essa parcela de controle, a fim de aumentar a estabilidade do sistema. Deixando para projetos futuros oportunidades de melhorias nesse controle. (SOARES e SACARPINETTI, 2012)

Sendo assim, segue o código utilizado para controlar a válvula borboleta:

void controle_vb()\{

/*Leitura da valvula borboleta do MC33972 */

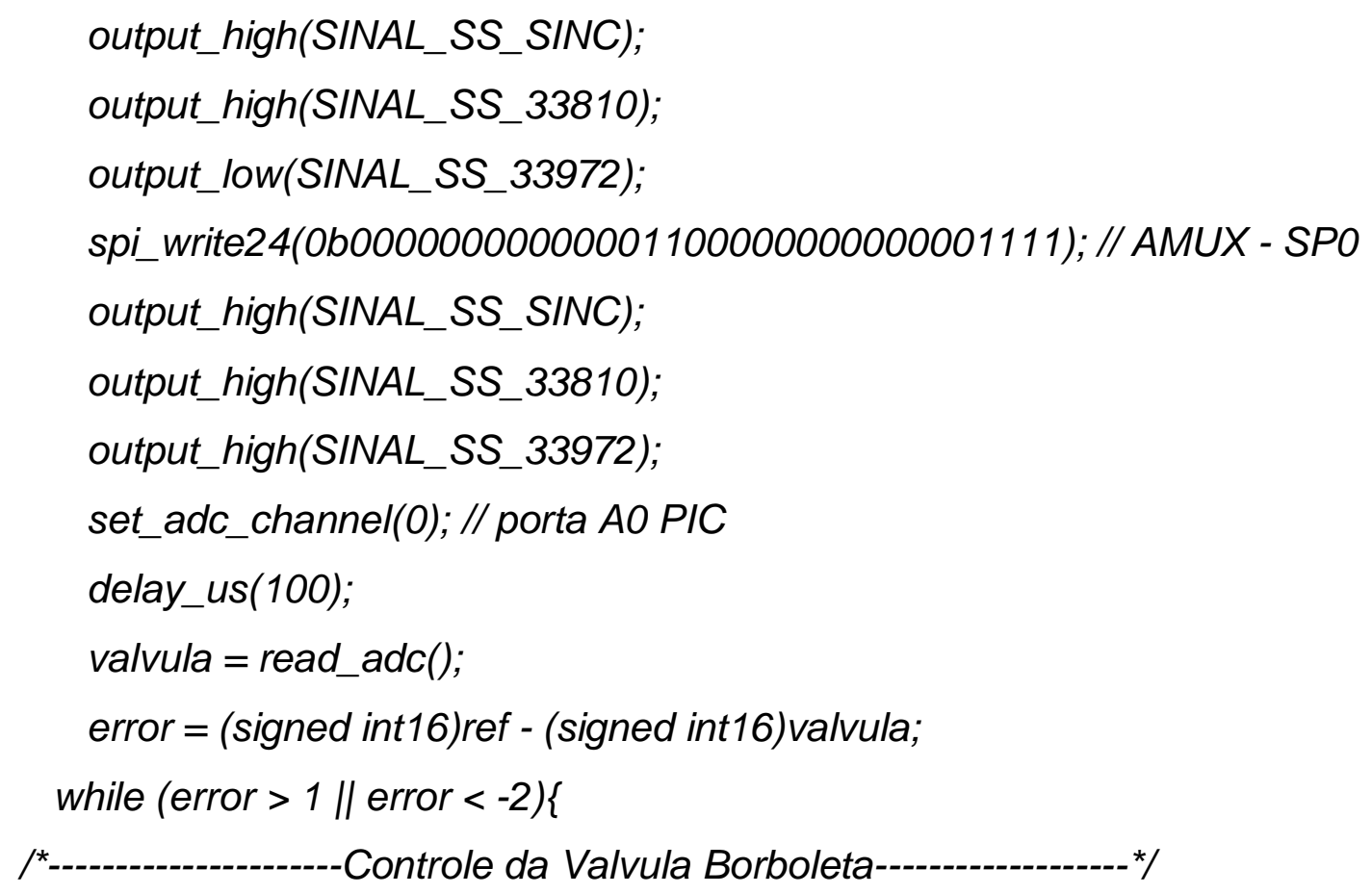

/*Leitura da valvula borboleta do MC33972 */

output_high(SINAL_SS_SINC);

output_high(SINAL_SS_33810);

output_low(SINAL_SS_33972); 
spi_write24(0b00000000000001100000000000001111); // AMUX - SPO output_high(SINAL_SS_SINC);

output_high(SINAL_SS_33810);

output_high(SINAL_SS_33972);

set_adc_channel(0); // porta AO PIC

delay_us(100);

valvula $=$ read_adc();

pwm_min $=20+0.17^{*}$ valvula;

/* Algoritmo de controle PID */

error = (signed int16)ref $-($ signed int16) valvula;

integral $+=$ error;

derivative = error - pre_error;

$P=K p$ * (float)error; $/{ }^{*}$ Termo Proporcional */

$I=K i$ * (float)integral; /* Termo Integrativo*

$D=0 ; / *$ Termo Derivativo*/

control $=P+I+D ; /{ }^{*}$ Sinal de controle */

$/{ }^{*}$ Calcula o PWM com o sinal de controle e o pwm minimo *

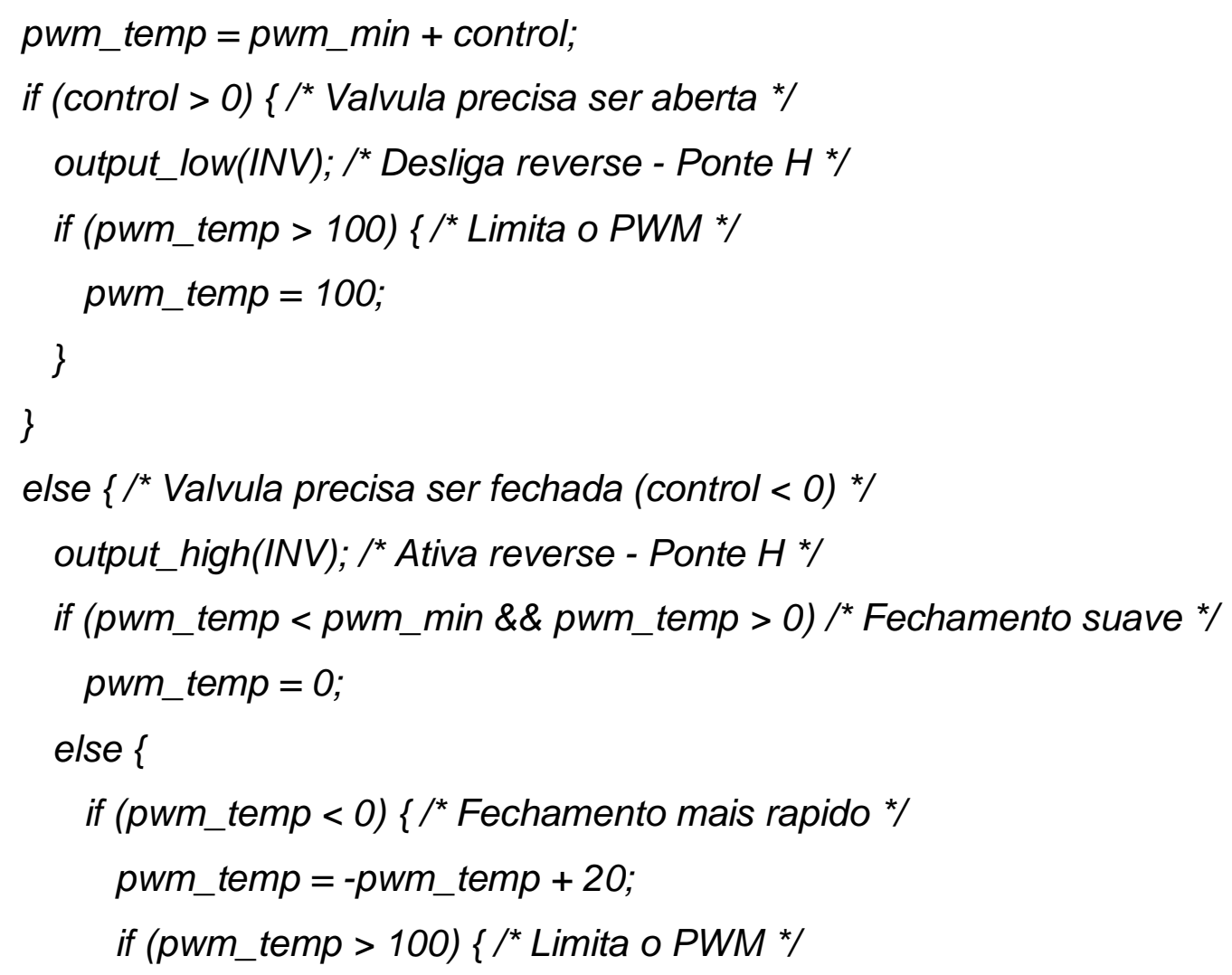




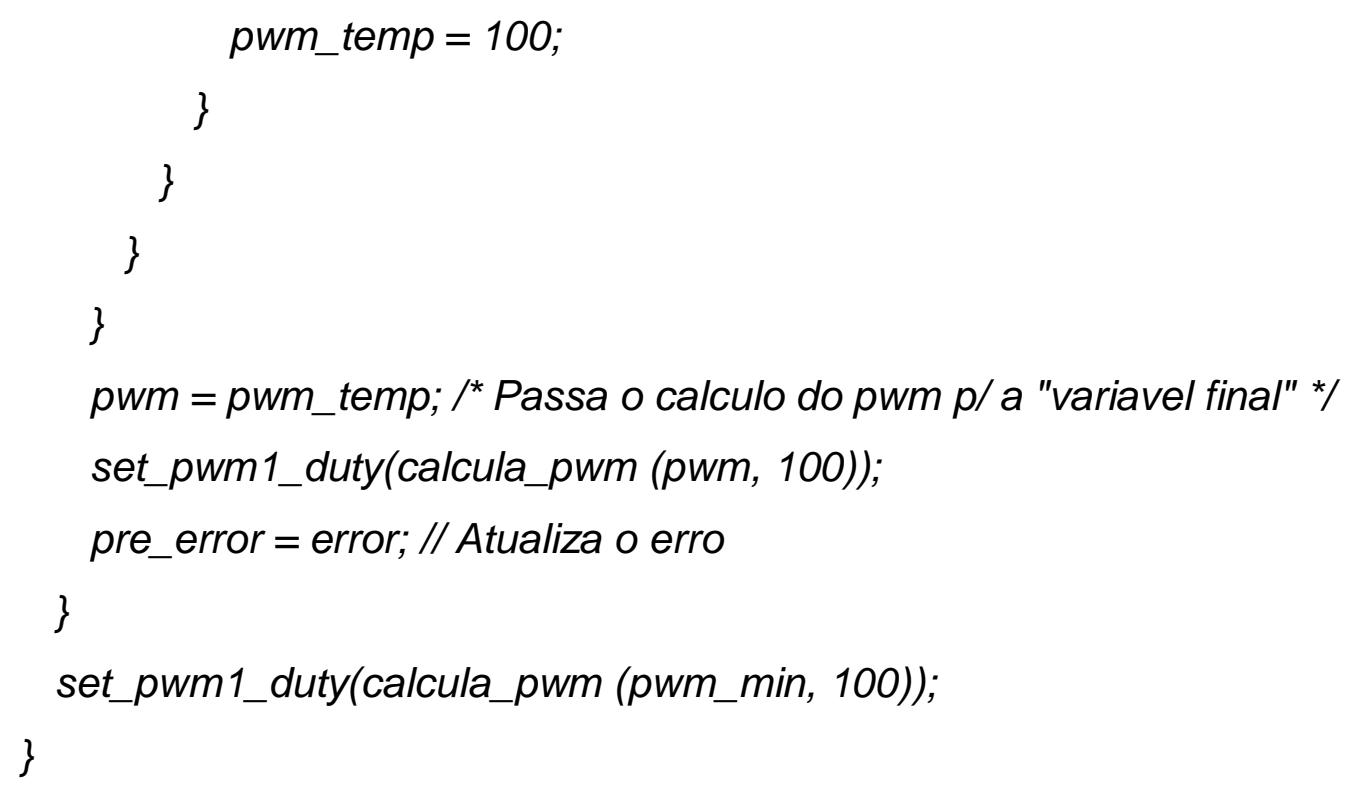

\subsubsection{Correção no momento de partida}

A estratégia de partida adotada para controlar esse motor foi abrir parcialmente a borboleta no momento em que o motor de partida já tiver atuando no motor e for atingido o dente de número 57 da roda fônica. Portanto, quando o motor de partida tirar o motor da inércia e for identificado através da interrupção externa o dente de número 57 da roda fônica, a válvula borboleta é aberta até a posição angular aproximada de $45^{\circ}$, permanecendo nessa posição por um período aproximado de 120 ms, voltando à posição de marcha lenta posteriormente.

Essa estratégia foi adotada para permitir uma maior entrada de ar no interior dos cilindros no momento da partida, uma vez que como a rotação do motor está muito baixa a depressão no coletor de admissão não é muito alta. Com isso, o ar aspirado para dentro dos cilindros não seria suficiente para gerar uma combustão capaz de elevar a rotação do motor rapidamente até alcançar um regime de marcha lenta.

O dente 57 foi escolhido, pois é o momento que permite que esse ar admitido percorra todo o coletor de admissão e adentre nos cilindros antes do primeiro e quarto pistões alcançarem o PMS. Com isso, é possível aproveitar melhor a energia da combustão e elevar rapidamente a rotação do motor. 


\subsubsection{Software de Sincronismo}

O programa do sistema de sincronismo depende basicamente do acontecimento de cinco interrupções para o funcionamento perfeito do motor, são elas as interrupções: externa, timer 0 , timer 2, timer 3 e via comunicação SPI.

A interrupção externa no programa do módulo se sincronismo tem a mesma função do módulo de gerenciamento e o código gravado nela é exatamente o mesmo, alterando somente a sub-rotina da função conta dente. Por isso serão descritos a seguir as interrupções do timer 0 , timer 2, timer 3 , SPI e a função conta dente. Onde o timer 0 e o timer 3 tem a função de controlar respectivamente a injeção nos cilindros $1 / 4$ e 2/3, o timer 2 controla o sistema de ignição, a interrupção via comunicação SPI é responsável por fazer a leitura dos parâmetros que estão sendo enviados do módulo de gerenciamento e a função conta dente é responsável por selecionar qual interrupção acontecerá em cada momento de acordo com os parâmetros recebidos via SPI.

\subsubsection{Função Conta Dente}

A função conta dente é chamada toda vez que uma interrupção externa tem sua origem por uma borda de descida. Como primeira função executada nessa subrotina, a variável "dente" é incrementada (respeitando o limite de 58) e os parâmetros que são captados pela interrupção SPI e são guardados em uma matriz "spi_ctr" são atualizados.

Nesse momento inicia-se uma sequência de decisões com a intenção de disparar os timers no momento exato, conseguindo dessa forma sincronizar o sistema de injeção e ignição do motor. Portanto, a função conta dente monitora a cada execução se está no momento de ignição ou injeção de algum cilindro. Caso esteja, o timer respectivo à atuação desejada é habilitado e uma posição referente a essa atuação é dada à variável ig_pos (caso seja o caso de um dente referente à ignição) ou ij_pos (caso seja o caso de um dente referente à injeção).

O fluxograma da figura 55 mostra o passo a passo dessa função, como pode ser visto a seguir: 


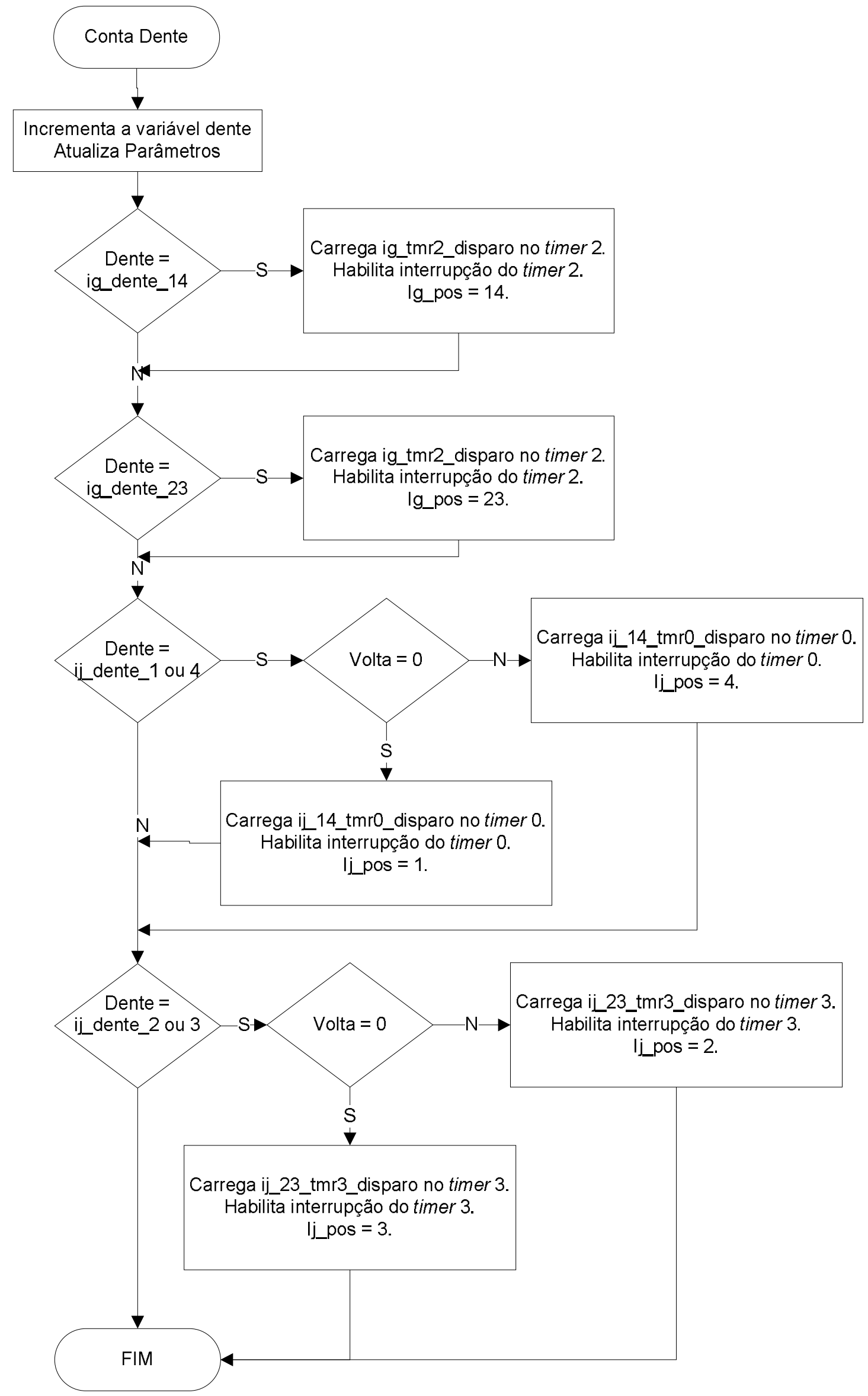

Figura 55 - Fluxograma da função conta dente. 


\subsubsection{Interrupção via Comunicação SPI}

A interrupção via comunicação SPI ocorre toda vez que um dado chega na porta SDI do microcontrolador do sistema de sincronismo. Essa interrupção tem a função de executar a leitura dos parâmetros transferidos pelo bloco de gerenciamento e armazenar esses dados em variáveis respectivas a cada parâmetro e com esses valores executar o controle dos sistemas de injeção de combustível e ignição do motor. Os parâmetros recebidos nessa função, bem como a função de cada um deles dentro do programa estão descritas na tabela 3 como pode ser visto a seguir:

Tabela 3 - Parâmetros Recebidos via Comunicação SPI.

\begin{tabular}{|c|c|c|}
\hline Parâmetros & $\begin{array}{l}\text { Tamanho } \\
\text { (bits) }\end{array}$ & Função \\
\hline Ig_dente_14 & 8 & $\begin{array}{l}\text { Indicar o dente exato que será disparado o pulso de atuação } \\
\text { da bobina de ignição responsável por gerar a centelha das } \\
\text { velas de ignição nos cilindros } 1 \text { e } 4 \text {. }\end{array}$ \\
\hline Ig_dente_23 & 8 & $\begin{array}{l}\text { Indicar o dente exato que será disparado o pulso de atuação } \\
\text { da bobina de ignição responsável por gerar a centelha das } \\
\text { velas de ignição nos cilindros } 2 \text { e } 3 \text {. Geralmente esse valor é } \\
\text { igual a } 30 \text { dentes a mais do que o ig_dente_14. }\end{array}$ \\
\hline Ig_tmr2_disparo & 8 & $\begin{array}{l}\text { Tempo que será carregado no timer } 2 \text { assim que o dente de } \\
\text { disparo da ignição (independente do cilindro) for alcançado. } \\
\text { Após esse tempo é gerado uma interrupção no timer } 2 \text { e o } \\
\text { carregamento da bobina é iniciado. }\end{array}$ \\
\hline T_carregamento & 8 & Tempo de carregamento da bobina. \\
\hline lj_dente_1 & 8 & $\begin{array}{l}\text { Indicar o dente exato que será disparado o pulso de atuação } \\
\text { na válvula injetora do cilindro } 1 \text { (ij_14_tmro_disparo). }\end{array}$ \\
\hline lj_dente_2 & 8 & $\begin{array}{l}\text { Indicar o dente exato que será disparado o pulso de atuação } \\
\text { na válvula injetora do cilindro } 2 \text { (ij_23_tmr3_disparo). }\end{array}$ \\
\hline lj_dente_3 & 8 & $\begin{array}{l}\text { Indicar o dente exato que será disparado o pulso de atuação } \\
\text { na válvula injetora do cilindro } 3 \text { (ij_23_tmr3_disparo). }\end{array}$ \\
\hline lj_dente_4 & 8 & $\begin{array}{l}\text { Indicar o dente exato que será disparado o pulso de atuação } \\
\text { na válvula injetora do cilindro } 4 \text { (ij_14_tmro_disparo). }\end{array}$ \\
\hline ij_14_tmr0_disparo & 16 & $\begin{array}{l}\text { Tempo que será carregado no timer } 0 \text { assim que o dente de } \\
\text { disparo de injeção dos cilindros } 1 / 4 \text { forem alcançados. Após } \\
\text { esse tempo é gerado uma interrupção no timer } 0 \text { e o pulso } \\
\text { de atuação nas válvulas injetoras é disparado. }\end{array}$ \\
\hline ij_23_tmr3_disparo & 16 & $\begin{array}{l}\text { Tempo que será carregado no timer } 3 \text { assim que o dente de } \\
\text { disparo de injeção dos cilindros } 1 / 4 \text { forem alcançados. Após } \\
\text { esse tempo é gerado uma interrupção no timer } 3 \text { e o pulso } \\
\text { de atuação nas válvulas injetoras é disparado. }\end{array}$ \\
\hline Modo_inj & 8 & $\begin{array}{l}\text { Indica qual será o modo de injeção utilizado (por exemplo: } \\
\text { sequencial) }\end{array}$ \\
\hline Tempo_inj & 16 & $\begin{array}{l}\text { Tempo carregado nos timers } 0 \text { e } 3 \text { referente ao tempo de } \\
\text { injeção de cada válvula injetora. }\end{array}$ \\
\hline
\end{tabular}




\subsubsection{Interrupção do Timer 2}

A interrupção do timer 2 é utilizada para executar o controle e o sincronismo do sistema de ignição do motor. Com essa interrupção é possível gerar sinais sincronizados para carregar as bobinas de ignição e gerar a faísca no momento correto de combustão dos cilindros.

O fluxograma da figura 56 mostra que para fazer isso, o programa ao iniciar a interrupção do timer 2 desabilita a interrupção do mesmo e executa uma função switch case em função da variável ig_pos (posição da ignição). Caso essa variável for 1 todos os cilindros terão suas velas de ignição desacionadas. Com o valor de ig_pos igual a 23 as velas de ignição dos cilindros 2 e 3 são acionadas, a interrupção do timer 2 é habilitada com o tempo de carregamento da bobina e a variável ig_pos é carregada com o valor de 1 para quando houver novamente uma interrupção o sinal de carregamento das bobinas sejam cessados. Já quando o valor de ig_pos for igual a 14 as velas de ignição dos cilindros 1 e 4 são acionadas, a interrupção do timer 2 é habilitada com o tempo de carregamento da bobina e a variável ig_pos é carregada com o valor de 1, tendo a mesma função descrita anteriormente.

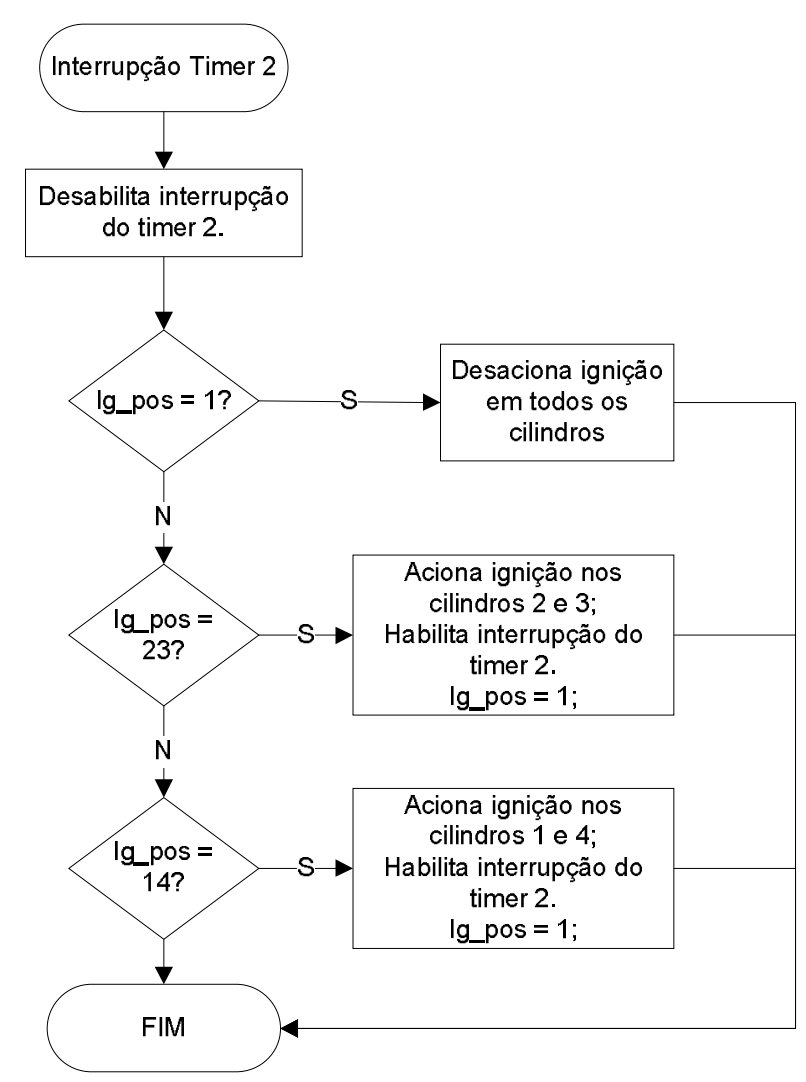

Figura 56 - Fluxograma do Sistema de Ignição. 


\subsubsection{Interrupção dos Timers 0 e 3}

A interrupção do timer 0/3 é utilizada para executar o controle e o sincronismo do sistema de injeção do motor. Sendo o timer 0 responsável pelo comando das válvulas injetoras 1 e 4 e o timer 3 responsável pelo comando das válvulas injetoras 2 e 3. Contudo a estratégia de comando para ambas as interrupções foram as mesmas alterando somente o momento de disparo de cada uma. O fluxograma da figura 57 mostra a sequência de passos que são executados nessas duas interrupções.

Inicialmente é desabilitada a interrupção do timer 0/3 e posteriormente uma sequência de decisões é tomada de acordo com os parâmetros recebidos do microcontrolador de gerenciamento. Para cada decisão uma estratégia de injeção pode ser adotada, elas são: sequencial, banco-a-banco, full-group, injeção para a partida, inversão da variável volta.

Como já foram explicados os modos de injeção sequencial, banco-a-banco e full group no capítulo 2.6.2, a seguir serão descritos o modo de injeção para a partida e a inversão da variável volta.

A injeção para partida é utilizada somente na primeira injeção do momento de partida. Essa estratégia adota uma integração com o modo de injeção full group, pois a injeção ocorre em todos os cilindros ao mesmo tempo. Porém, além disso, o tempo de injeção é maior que o normal, alcançando valores superiores a $30 \mathrm{~ms}$. Isso acontece para suprir a quantidade mássica de ar que é admitida com a abertura da válvula borboleta no momento de partida.

A estratégia de inversão da variável volta: só é adotada quando no momento de transição entre a estratégia banco-a-banco e sequencial a escolha do cilindro para começar a injetar tenha sido errada. Como o motor que foi escolhido para o desenvolvimento desse trabalho não possui sensor de fase é necessário nesse momento de transição escolher aleatoriamente um cilindro para iniciar a injeção sequencial. Porém se esse cilindro escolhido primeiramente não estiver no momento de admissão a rotação do motor começará a cair. Portanto, se isso ocorrer a variável volta deve ser invertida com o intuito de corrigir a fase do motor. 


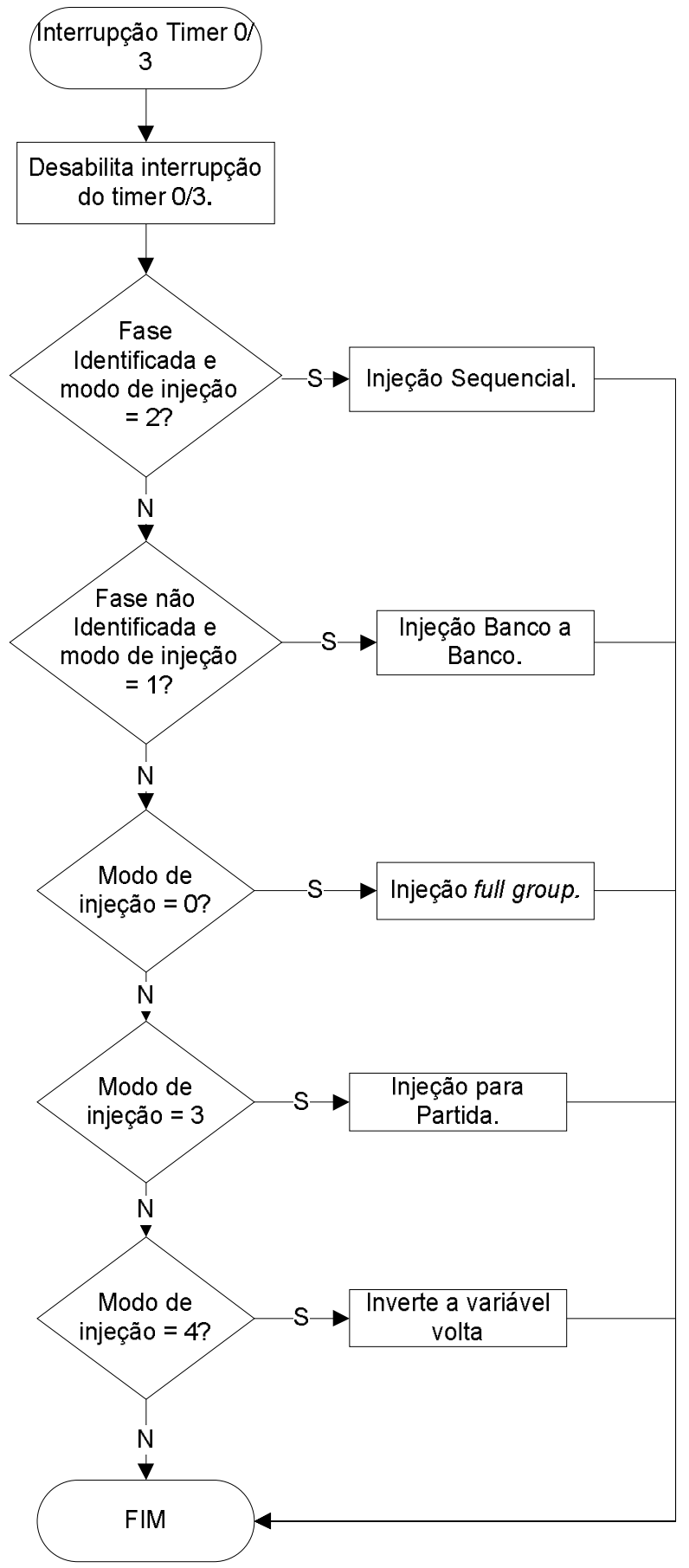

Figura 57 - Fluxograma do Sistema de Injeção. 


\section{RESULTADOS E DISCUSSÕES}

Neste capítulo serão demonstrados os testes práticos executados desde o início do desenvolvimento da ECU até a conclusão do projeto. Testes estes efetuados primeiramente para a confirmação do funcionamento correto e desejado dos componentes do hardware (condicionadores de sinais, regulador de tensão, drivers de potência, etc) e software desenvolvidos.

Seguindo com a validação posterior do software onde alguns sinais de controle foram comparados com a ECU original para permitir maior confiabilidade no momento do teste final onde a ECU original foi completamente substituída pela ECU desenvolvida e descrita nesse trabalho.

\subsection{TESTES INICIAIS}

Os resultados iniciais foram obtidos a partir de uma plataforma constituída de um gerador de sinal da roda fônica e uma placa eletrônica multiuso (figura 58), cuja configuração foi feita em conjunto pela FATEC Santo André e EPUSP e fabricada pela empresa Labtools. O gerador de sinal citado é, por sua vez, constituído de um inversor de frequência (para controle da rotação), motor elétrico com roda dentada acoplada, sensor de relutância magnética, circuito de interface para enquadramento do sinal e uma fonte de tensão 440W (fonte de computador).

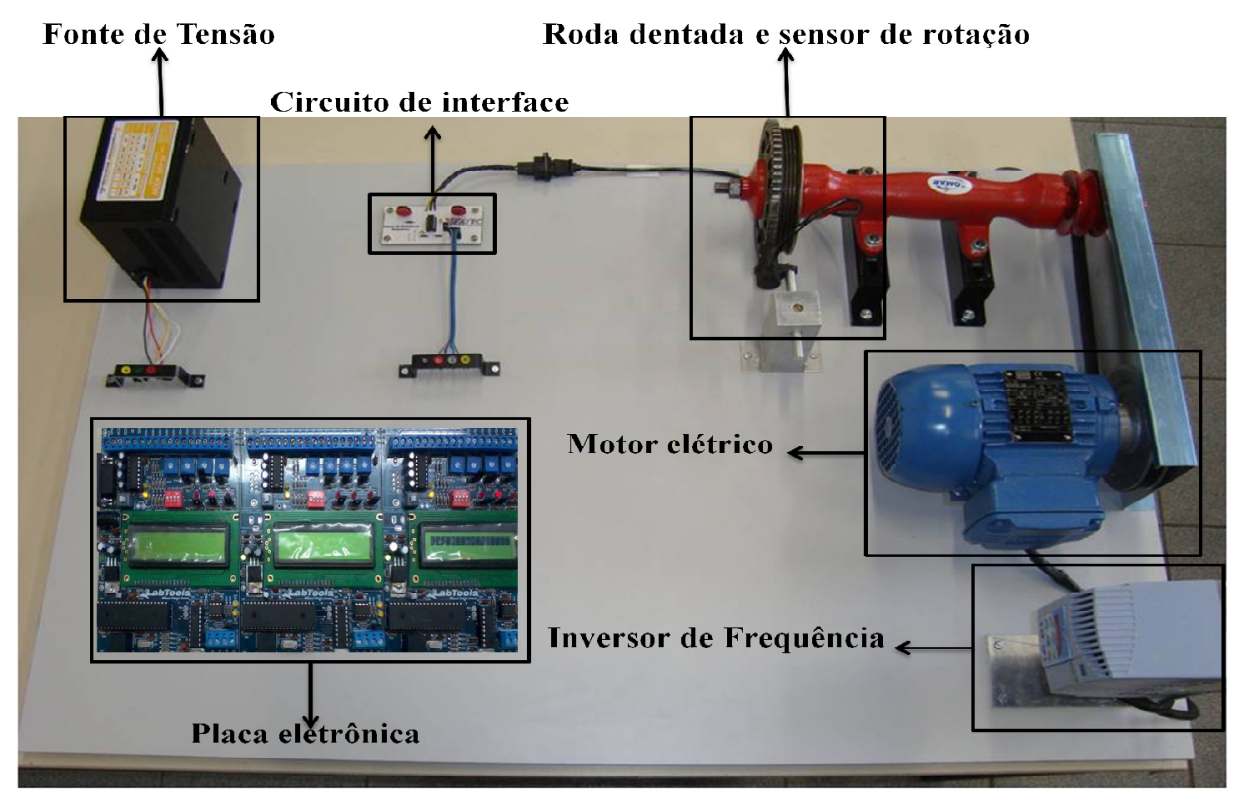

Figura 58 - Plataforma utilizada para testes inicias do projeto. 
A placa por sua vez é constituída por três blocos independentes contendo cada, um microcontrolador. PIC18F452, componentes para comunicação CAN (não utilizada) e outros componentes periféricos (switches, LEDs, potenciômetros entre outros). Os sinais foram obtidos utilizando-se o osciloscópio Tektronix modelo TDS 2014B (4 canais).

\subsubsection{Validação do software de sincronismo, da comunicação SPI e da interface do condicionamento do sinal de rotação do motor}

Através da plataforma ilustrada na figura 58 foi possível iniciar o desenvolvimento do software dos módulos de sincronismo e gerenciamento, pois com ela foi possível simular a rotação do motor em diversas faixas, comandando o motor elétrico através do inversor de frequência, conseguindo alcançar um range de rotação de 0 até 6000 rpm.

Com isso foi possível validar a interface utilizada para enquadrar o sensor de relutância magnética (LM1815) e iniciar o desenvolvimento do software de gerenciamento, captando o sinal de rotação e através de valores tabelados inicialmente transmitir para o módulo de sincronismo os parâmetros necessários para gerar os sinais de controle dos sistemas de ignição e injeção.

Inicialmente os valores desses parâmetros transmitidos do módulo de gerenciamento ao módulo de sincronismo não tinham uma importância muito grande, pois, a ideia desse primeiro teste foi validar a leitura do sensor de rotação, a transmissão de dados via comunicação SPI e as estratégias adotadas no programa de sincronismo. Para fazer isso, após o programa gravado na placa de apoio, o sinal do sensor de rotação condicionado foi ligado a essa placa e o programa começou a rodar. Para testá-lo foi utilizado um osciloscópio de 4 canais da Tektronix modelo 2014B.

As figuras 59 e 60 mostram os pulsos obtidos para controle do sistema de ignição, respectivamente para 2300rpm e 4500rpm, onde foram tabelados como dentes de referência (lg_dente_14 e lg_dente_23) para início do disparo dos sinais o dente 15 para os cilindros 2 e 3 e o dente 45 para os cilindros 1 e 4 . Fixou-se ainda tempo de acionamento (Ig_tmr2_disparo) igual a 200us e o tempo de carregamento (t_carregamento) igual a $2 \mathrm{~ms}$. 
Com esses dois oscilogramas foi possível certificar-se que o sinal de rotação proveniente do sensor de relutância estava sendo perfeitamente enquadrado pelo circuito condicionador de sinal, uma vez que ao observar o canal 1 (amarelo) podese ver o sinal de rotação totalmente condicionado pelo LM1815.

Com o sensor de relutância magnética sendo condicionado corretamente, foi possível observar que o início dos pulsos de ignição, gerados pelo módulo de sincronismo, encontram-se exatamente 200us após os dentes 45 (canal 2) e 15 (canal 3), assim como foi tabelado no módulo de gerenciamento.

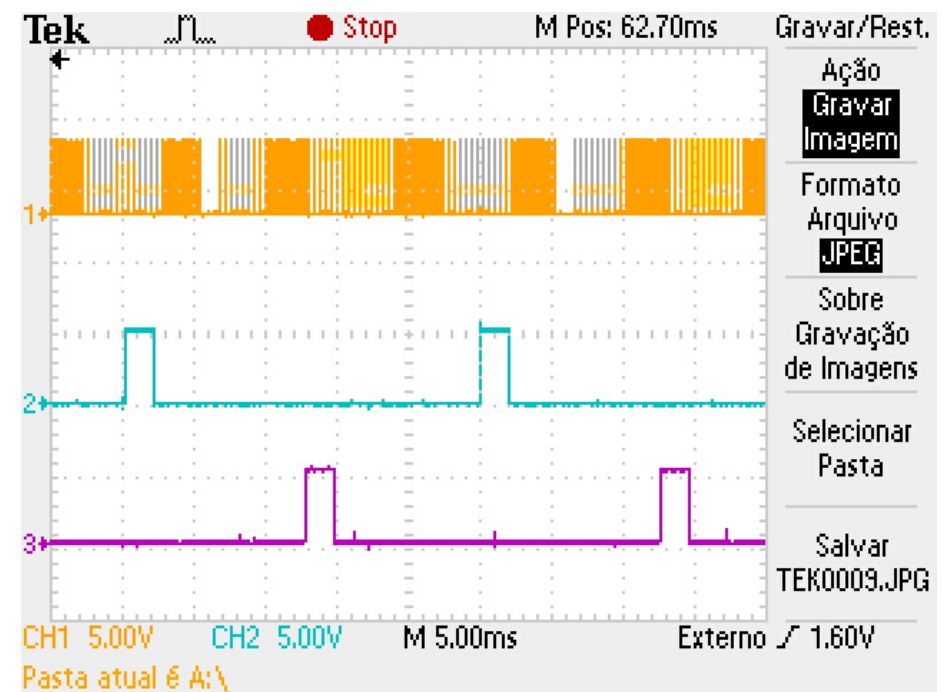

Figura 59- Sinal de ignição a 2300rpm.

Isso prova que além de os módulos de gerenciamento e sincronismo estarem lendo corretamente a rotação, a comunicação SPI entre eles também está funcionando, pois somente com os parâmetros sendo transmitido de uma forma correta, o software de sincronismo atuaria da forma como atuou: com os acionamentos feitos no momento tabelado pelo módulo de gerenciamento.

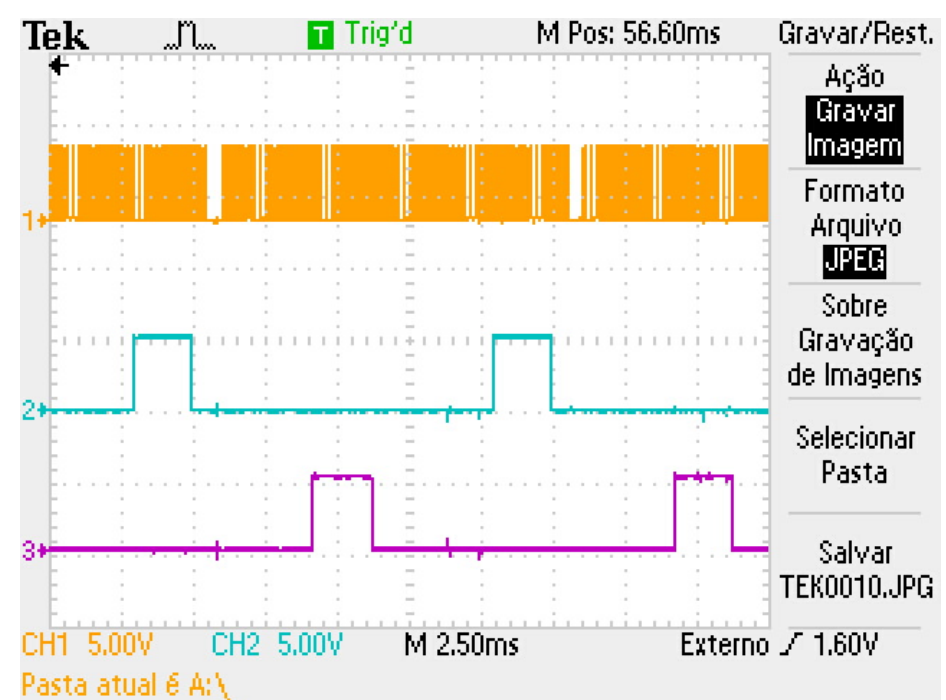

Figura 60. Sinal de ignição a 4500rpm. 
Para finalizar a validação do software de sincronismo e da confiabilidade da transmissão dos parâmetros, os sinais do sistema de injeção também foram analisados. As figuras 61 e 62 mostram os pulsos obtidos para o controle do sistema de injeção respectivamente para 2700rpm e 4500rpm, onde foram fixados como dentes de referência (ij_dente_1, ij_dente_2, ij_dente_3 e ij_dente_4) o dente 2 para os cilindros 1 e 4 e o dente 32 para os cilindros 2 e 3 . Fixou-se ainda o tempo de acionamento (ij_14_tmro_disparo, ij_23_tmr3_disparo) igual a 200us, tempo de injeção (tempo_inj) igual a $2 \mathrm{~ms}$ e modo de injeção (modo_inj) para uma injeção sequencial.

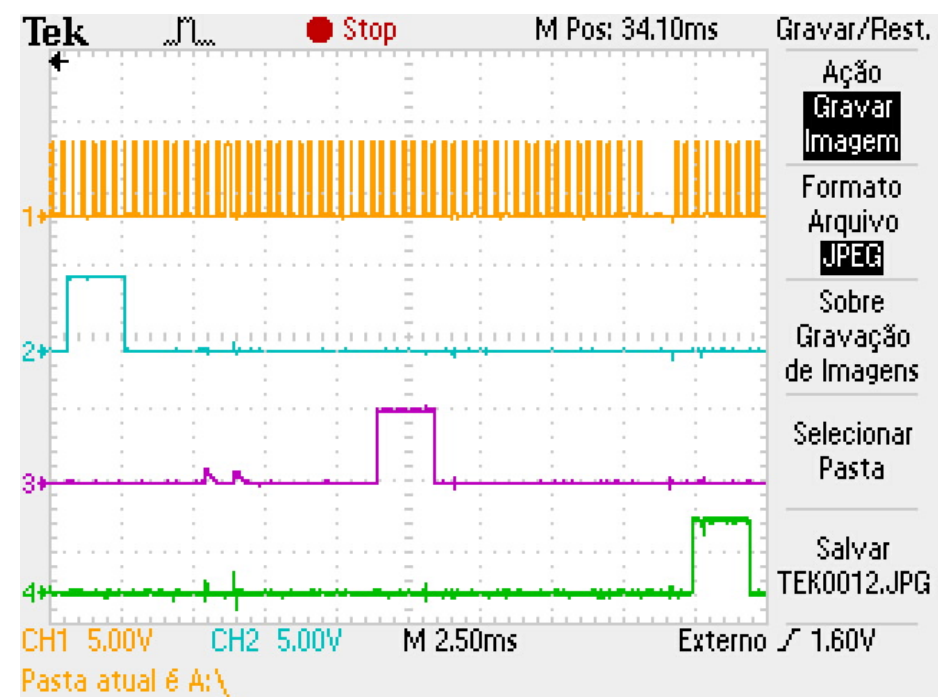

Figura 61. Sinal de injeção a 2700rpm.

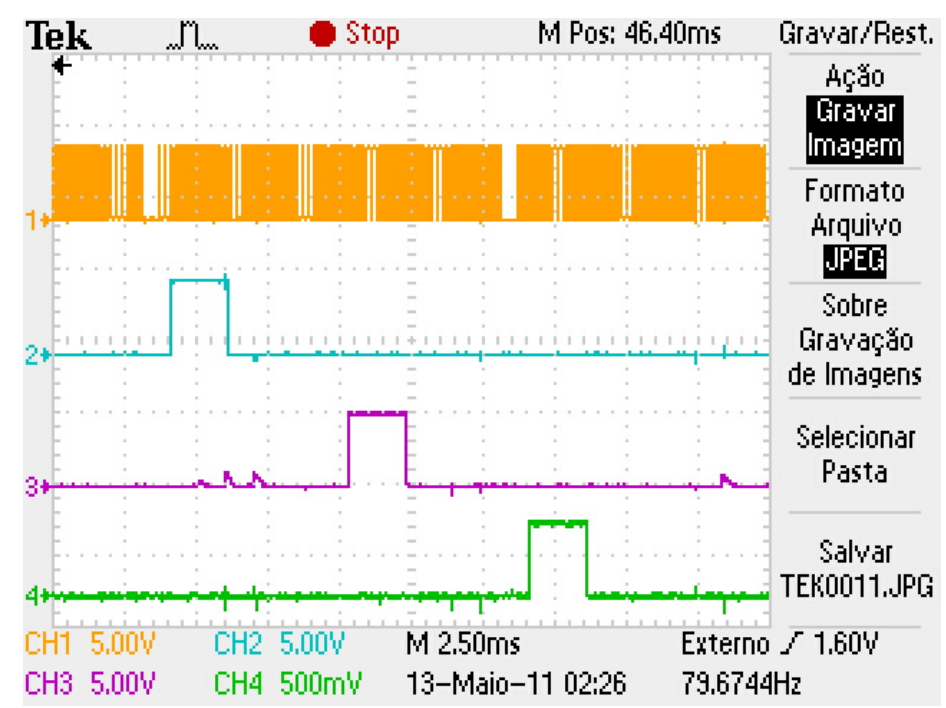

Figura 62. Sinal de injeção a 4500rpm.

Com isso é possível observar através desses oscilogramas no canal 1 o sinal de rotação condicionado pelo circuito de interface LM1815, no canal 2 o pulso de comando referente ao acionamento da válvula injetora do cilindro 1, no canal 3 o pulso de comando referente ao acionamento da válvula injetora do cilindro 3 e no 
canal 4 o pulso de comando referente ao acionamento da válvula injetora do cilindro 4.

Com esses testes iniciais foi possível identificar que o programa de sincronismo respondeu exatamente conforme os parâmetros transmitidos a ele pelo sistema de gerenciamento. Com isso, a fase de testes em bancadas se finaliza, iniciando a partir de então testes e comparações realizados no mock-up desenvolvido e mostrado no capitulo 3.2 .

\subsection{ECU ORIGINAL x ECU DESENVOLVIDA}

Com a intenção de comprovar a veracidade de todo o programa de gerenciamento e sincronismo antes de introduzir o controle diretamente no motor, uma comparação entre os sinais gerados pela ECU original do motor e a ECU desenvolvida foi feita.

Utilizando o mock-up e o interseccionamento da ECU original, foram captados todos os sinais necessários para o programa de gerenciamento e sincronismo manter uma funcionalidade perfeita, encaminhando-os para o hardware da ECU desenvolvida em paralelo com a ECU original. Dessa forma foi possível manter o motor funcionando integralmente (com a ECU original), mesmo conectando os sinais de alguns sensores na ECU desenvolvida assim como ilustra a figura 63.
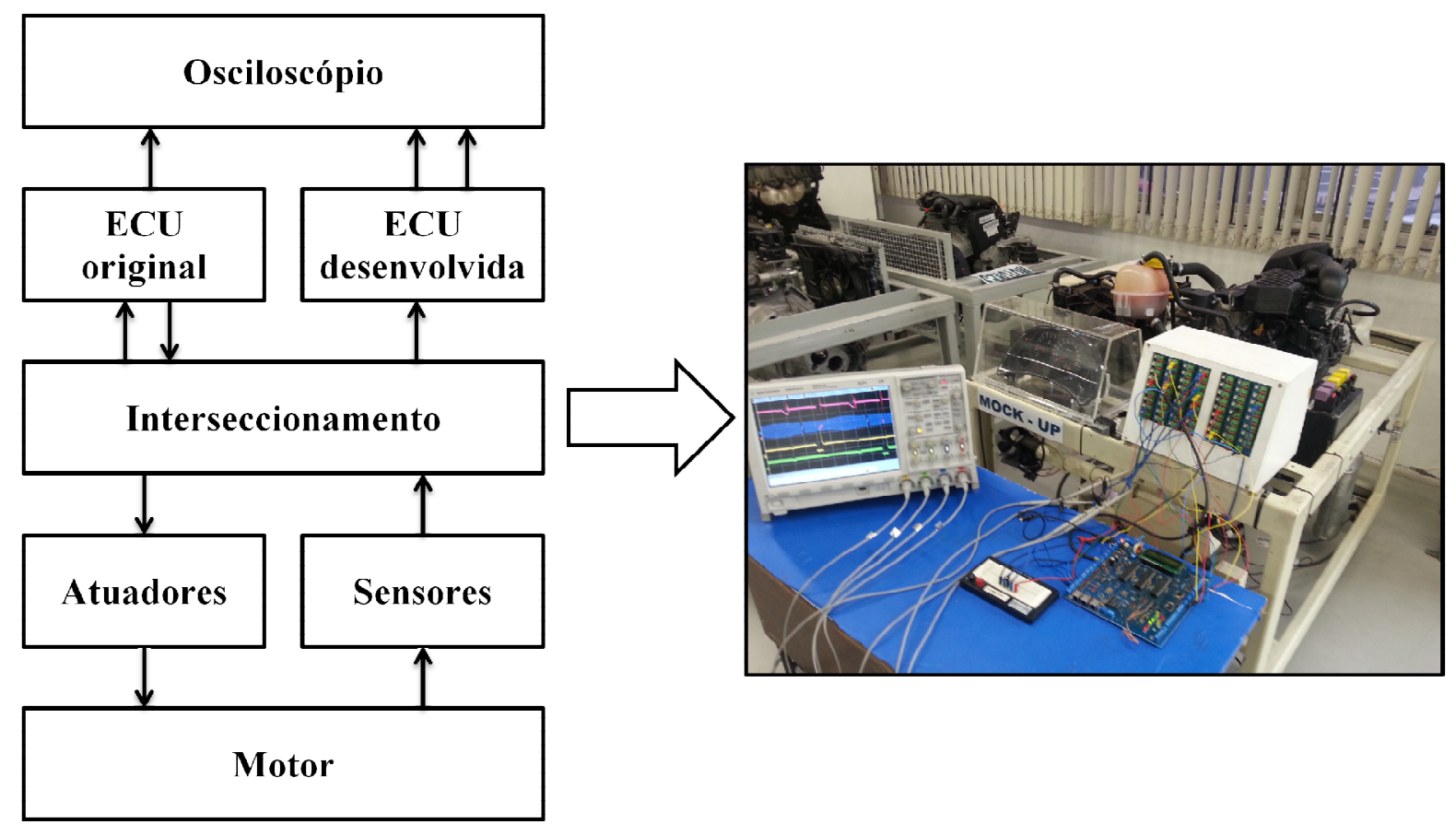

Figura 63 - Esquemático de ligações do circuito de testes. 
Com esse esquema de testes foi captado diversos sinais de comparação, tendo sempre como referencia o sinal de rotação condicionado pela ECU desenvolvida. Algumas figuras que demonstram a comparação de tempo de duração e momento de disparo dos sinais de injeção e ignição de cada cilindro podem ser observadas a seguir, sendo que o sinal do canal um do osciloscópio sempre será o sinal do atuador do motor, o sinal do canal dois sempre será o sinal de rotação já condicionado pela ECU desenvolvida e por fim o canal três será o pulso gerado pelo microcontrolador do módulo de sincronismo.

Na figura 64 é possível observar o sinal da válvula injetora do primeiro cilindro, que apresenta boa compatibilidade ao pulso gerado pela ECU original, pois coincide exatamente o dente inicial do disparo (ij_dente_1) e o tempo em que o atuador fica acionado (tempo_inj) do pulso original com o pulso gerado pelo módulo de sincronismo.

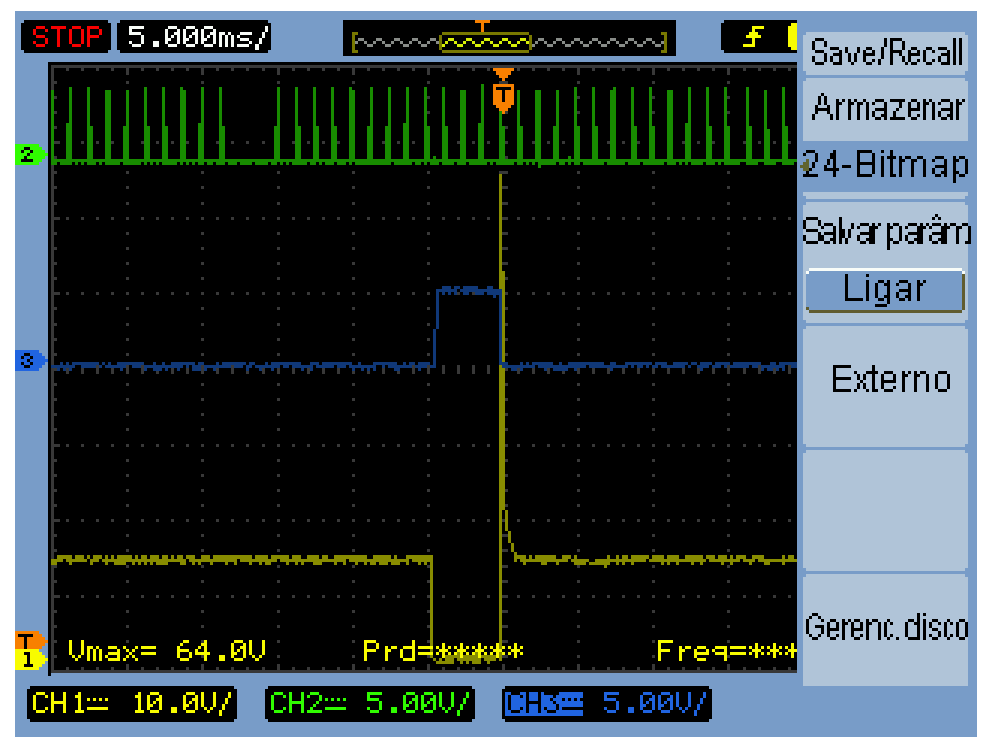

Figura 64 - Comparação entre sinal de injeção da válvula injetora do primeiro cilindro da ECU original e da ECU desenvolvida.

$\mathrm{Na}$ figura 65 observa-se que os sinais entre módulo original e o módulo desenvolvido referente a válvula injetora do cilindro 2 não são exatamente iguais. Uma vez que o dente inicial de disparo (ij_dente_2) é praticamente o mesmo, porém o tempo de duração dos pulsos se diverge em aproximadamente $360 \mu$ s para menos, ou seja, a ECU original está ativando alguma estratégia de correção do tempo de injeção que ainda não estava sendo prevista nesse projeto. 


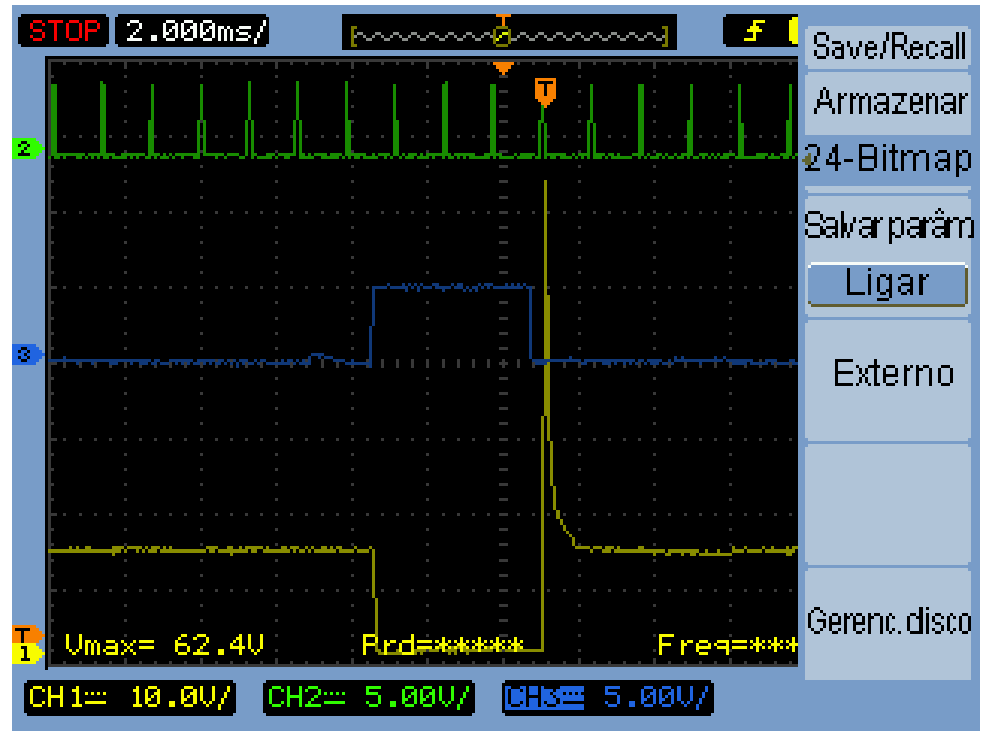

Figura 65 - Comparação entre sinal de injeção da válvula injetora do segundo cilindro da ECU original e da ECU desenvolvida.

Na figura 66 tanto o dente inicial (ij_dente_3) quanto o tempo de acionamento (tempo_inj) da válvula injetora do cilindro 3 estão diferentes. No primeiro há uma divergência de valores de $360 \mu$ s variando para menos no sinal provido da ECU desenvolvida. No final do pulso esse valor cai para $280 \mu$ s a mais no sinal original. Esses dois valores estando diferentes do nominal alteram o tempo de injeção, fazendo com que esse reduza aproximadamente $640 \mu \mathrm{s}$.

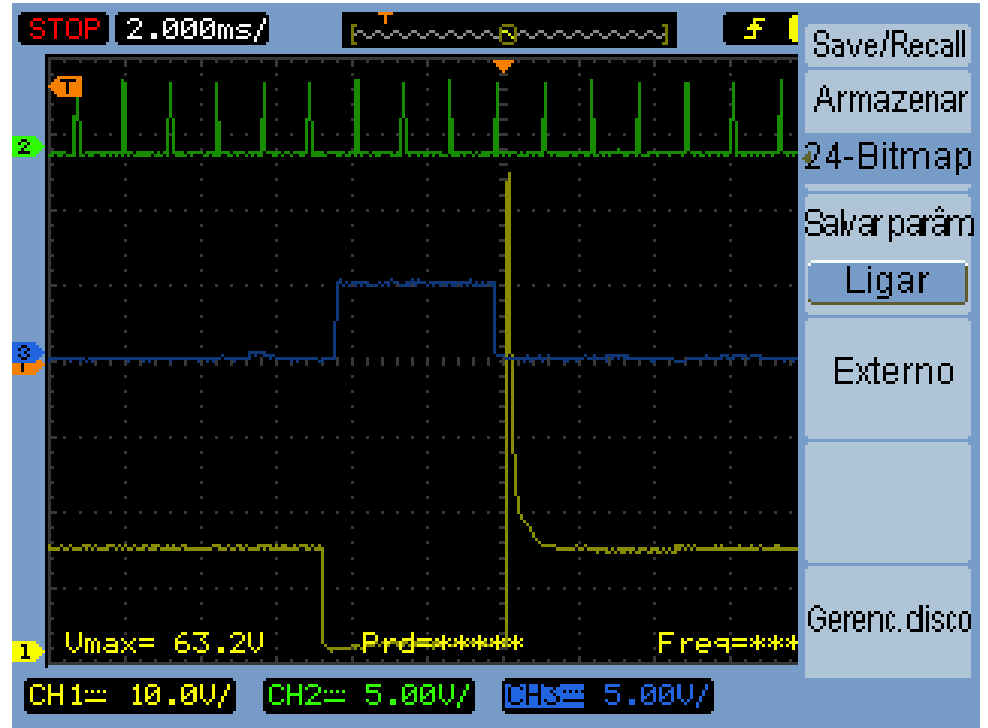

Figura 66 - Comparação entre sinal de injeção da válvula injetora do terceiro cilindro da ECU original e da ECU desenvolvida.

O sinal de injeção do quarto cilindro, visualizado na figura 67, também não está com total simetria com o sinal da ECU original. Nesse caso a divergência de medidas se encontra no momento inicial do disparo (ij_dente_4), onde o sinal gerado 
pelo módulo de controle do motor original inicia o pulso de injeção $360 \mu$ s antes do módulo de sincronismo.

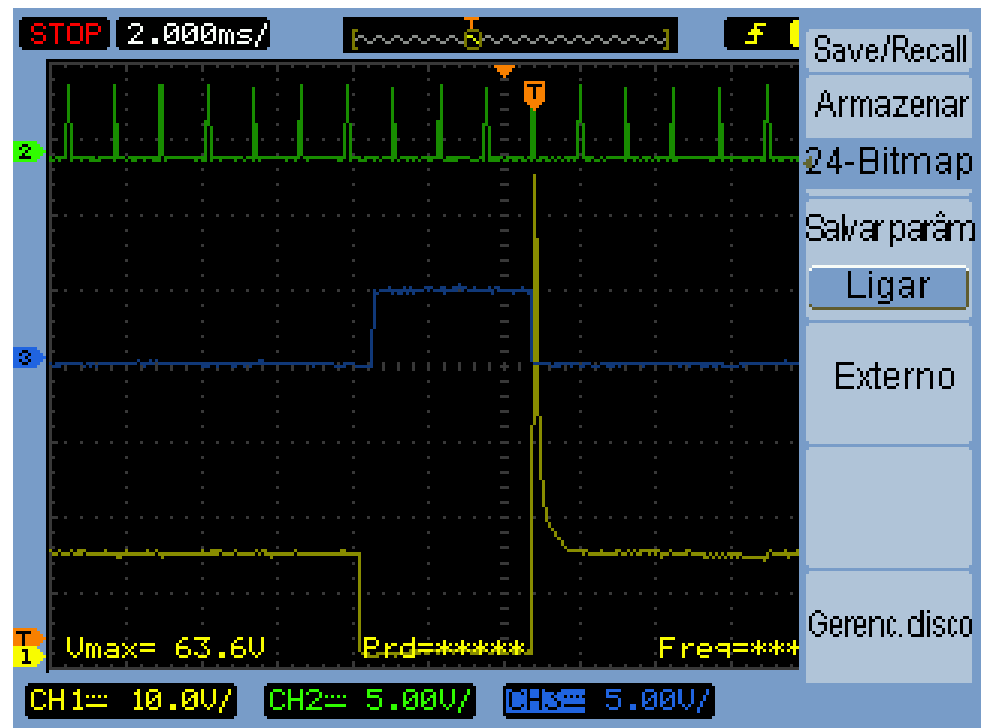

Figura 67- Comparação entre sinal de injeção da válvula injetora do terceiro cilindro da ECU original e da ECU desenvolvida.

No acionamento da bobina responsável por gerar energia para as velas dos cilindros dois e três foi identificada uma pequena divergência do valor do tempo de carregamento. Nesse caso há $200 \mu$ de atraso no início do acionamento e $160 \mu$ s de retardo para cortar o pulso que está alimentando a bobina, resultando uma alteração

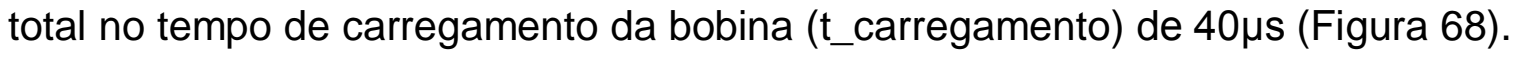

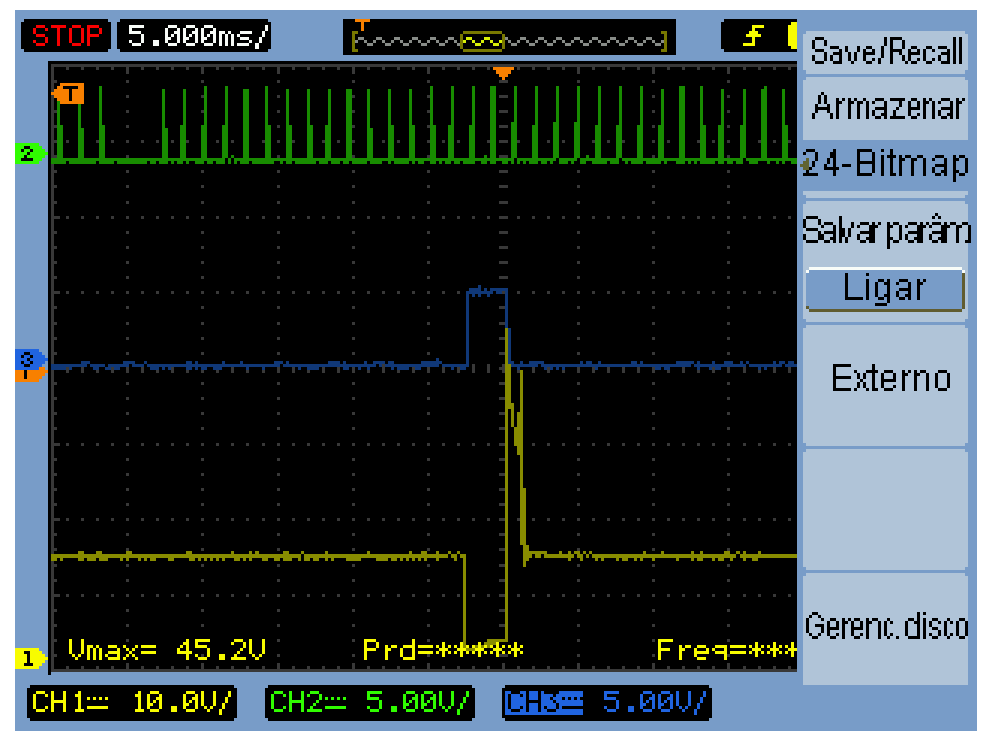

Figura 68 - Comparação entre sinal de ignição das velas do segundo e terceiro cilindros da ECU original e da ECU desenvolvida.

A figura 69 mostra a imagem de comparação entre a ECU original e a desenvolvida do sinal de energização da bobina responsável por energizar as velas dos cilindros um e quatro. Esse sinal não está totalmente simétrico, contendo um pequeno desvio no tempo inicial de acionamento (t_ig_14) de $240 \mu s$ de atraso, ou 
seja o módulo de sincronismo está liberando o pulso de ignição para os cilindros um e quatro $240 \mu$ s depois que a unidade de controle do motor envia o mesmo pulso de comando.

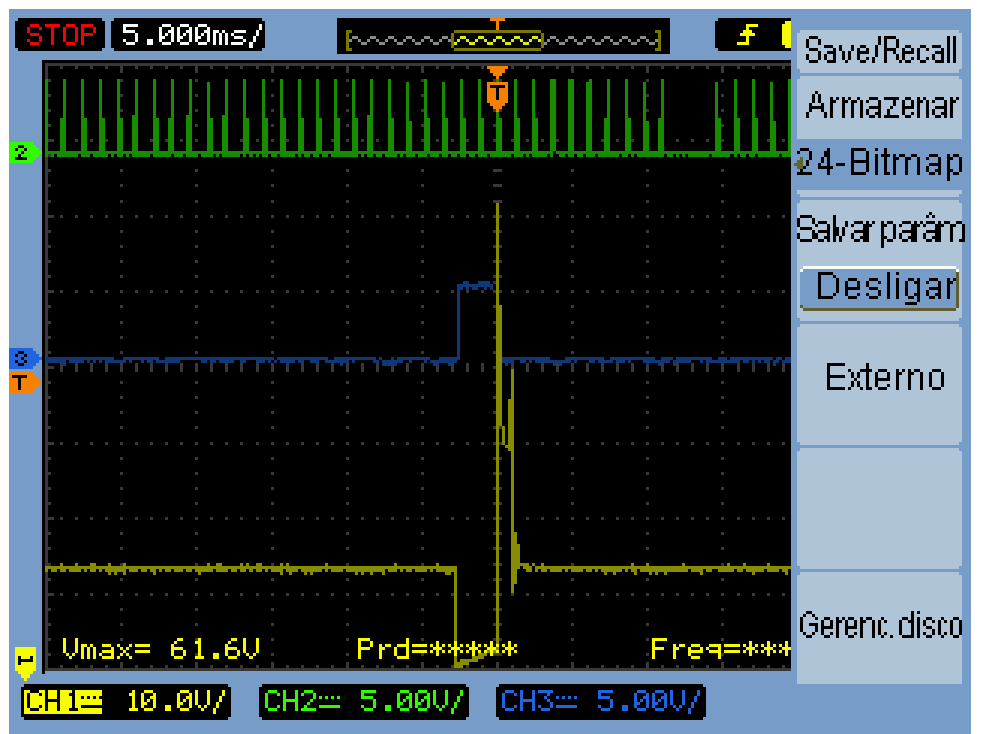

Figura 69 - Comparação entre sinal de ignição das velas do primeiro e quarto cilindros da ECU original e da ECU desenvolvida.

\subsection{TESTES FINAIS}

Após comparar os sinais gerados pela ECU desenvolvida com a ECU original e obter resultados bem semelhantes. A ECU desenvolvida e descrita nesse trabalho foi testada no motor do mock-up descrito anteriormente e foi possível obter resultados com o motor funcionando nos regimes de: partida a frio e a quente, marcha lenta, aceleração (com o motor sem carga) e desaceleração (utilizando a estratégia de cut-off).

\subsubsection{Regime de Partida}

O momento de partida de um motor é o momento crucial para que um motor entre em funcionamento. Como descrito anteriormente a estratégia adotada nesse momento foi de iniciar o movimento rotativo do motor através do motor de partida, seguindo de uma branda abertura da válvula borboleta com o modo de injeção inicial sendo exclusivo para a partida, alterando para o modo de injeção full group logo em seguida. 
É possível observar na figura 70 um sinal capturado de um osciloscópio Agilent Technologies de 4 canais com uma taxa de amostragem de100MHertz, no canal 2 (verde) o sinal de rotação do motor após passar pelo condicionamento do circuito integrado LM1815, assim como se observa no canal 1 (amarelo) o sinal do TPS, no canal 3 (roxo) o sinal de injeção do cilindro 1 e no canal 4 (rosa) o sinal gerado pelo PIC toda vez que é reconhecido a falha (falta de dois dentes da roda fônica) no sinal de rotação.

É possível perceber que o sinal de rotação no início da imagem está sempre em zero, o que significa que o motor está parado. Conforme o motor de partida é acionado o motor sai da inércia e inicia-se um aumento gradual em sua rotação. Ao alcançar aproximadamente 200rpm a válvula borboleta abre parcialmente permitindo uma admissão maior de ar, o que pode ser constatado com o aumento de tensão do sinal do TPS. Diante disso a injeção de combustível inicia-se com uma quantidade grande de combustível na primeira injeção (injeção para a partida), com o intuito de fornecer combustível suficiente para suprir a demanda de ar que foi admitida, como pode ser observado no primeiro pulso da válvula injetora do cilindro um.

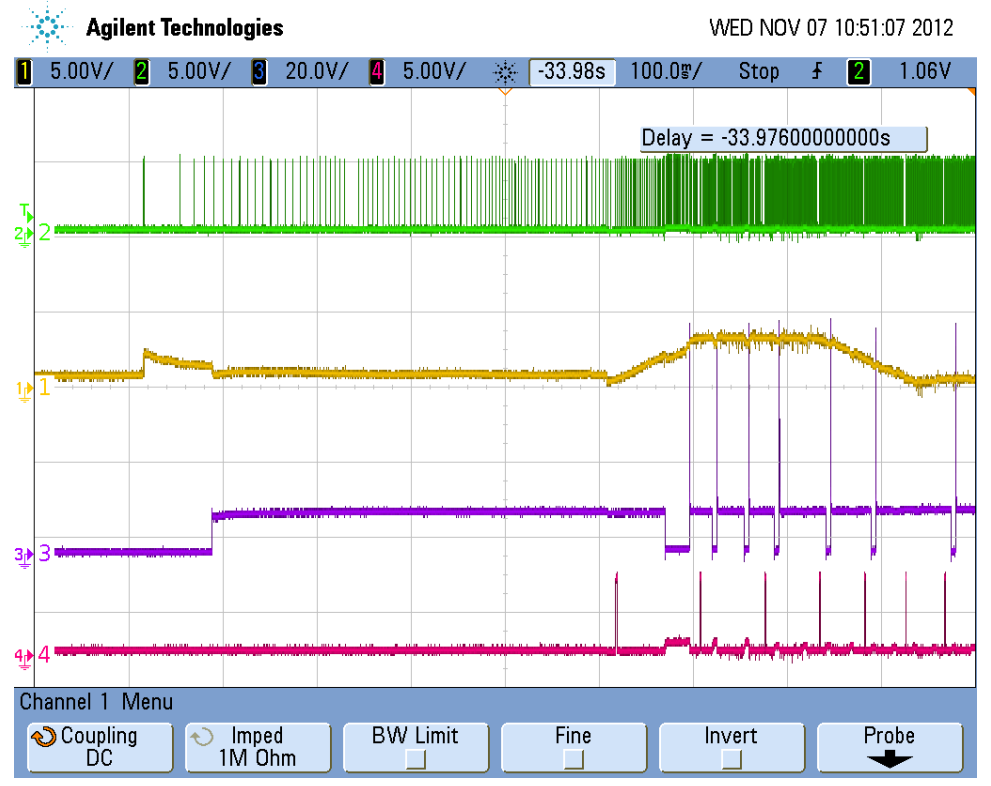

Figura 70 - Sinal capturado no osciloscópio no momento de partida do motor.

Após isso o motor se mantém em uma injeção full group até alcançar os 600rpm, passando para uma injeção banco-a-banco que permanece até o motor alcançar uma rotação de 1200rpm, onde inicia o modo de injeção sequencial juntamente com o regime de marcha lenta. 


\subsubsection{Regime de Marcha Lenta}

No momento onde o modo de injeção é alterado para sequencial o regime de marcha lenta se inicia e dependendo da temperatura do líquido de arrefecimento do motor a rotação nesse regime varia entre 1200 e 800rpm. A figura 71 mostra um gráfico capturado pelo mesmo osciloscópio da figura anterior no momento em que 0 motor se encontrava no regime de marcha lenta.

Nessa figura é possível observar o sinal de rotação no canal 1 (amarelo), a identificação da falha do sinal de rotação no canal 2 (verde), o sinal de comando dos injetores 1 no canal 4 (rosa) e 3 no canal 3 (roxo). O regime de marcha lenta capturado nessa figura refere-se a uma condição de aquecimento do motor, ou seja, a temperatura do líquido de arrefecimento está abaixo de $90^{\circ} \mathrm{C}$, por isso a rotação nesse oscilograma é de aproximadamente 1200rpm e o tempo de injeção está mantendo uma mistura rica de combustível para um aquecimento mais rápido desse motor com aproximadamente $4,3 \mathrm{~ms}$ de tempo de injeção.

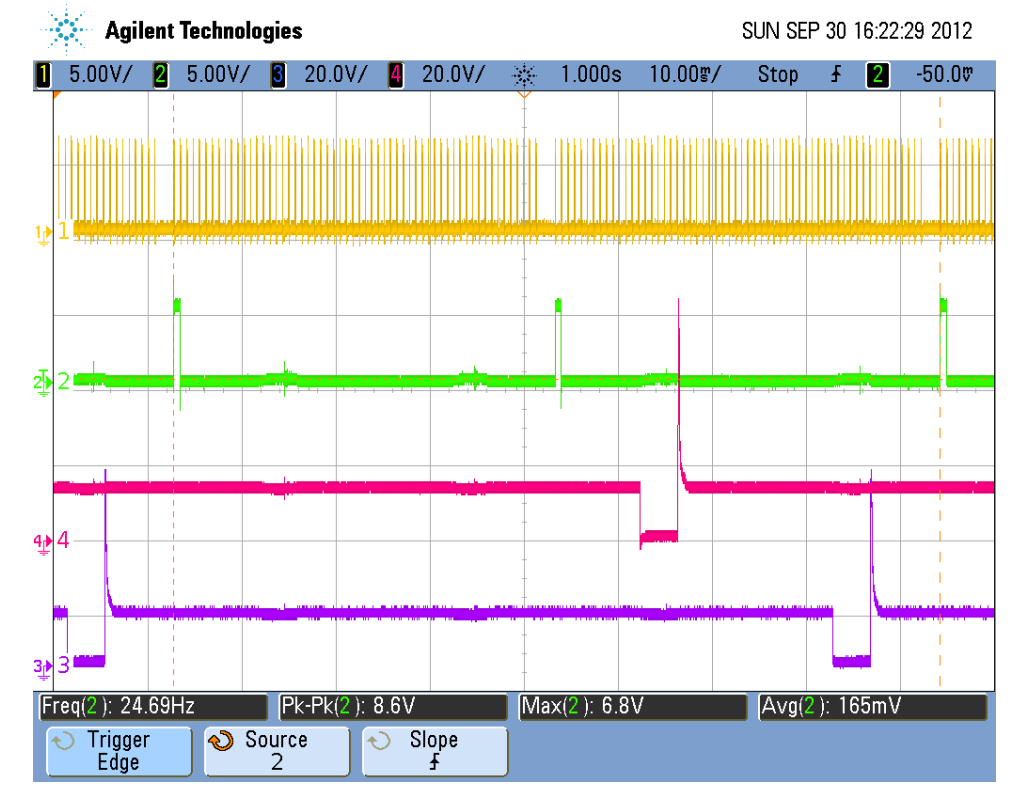

Figura 71 - Sinal capturado no osciloscópio em regime de marcha lenta do motor.

\subsubsection{Regime de Aceleração e Desaceleração do Motor}

Ainda foi possível observar um comportamento do motor em regimes de aceleração e desaceleração assim como ilustra o oscilograma da figura 72. Nessa figura é possível observar o sinal de rotação no canal 2 (verde), o sinal do pedal do 
acelerador no canal 4 (rosa) e os sinais dos injetores 1 e 3 no canais 1 (amarelo) e 3 (roxo) respectivamente.

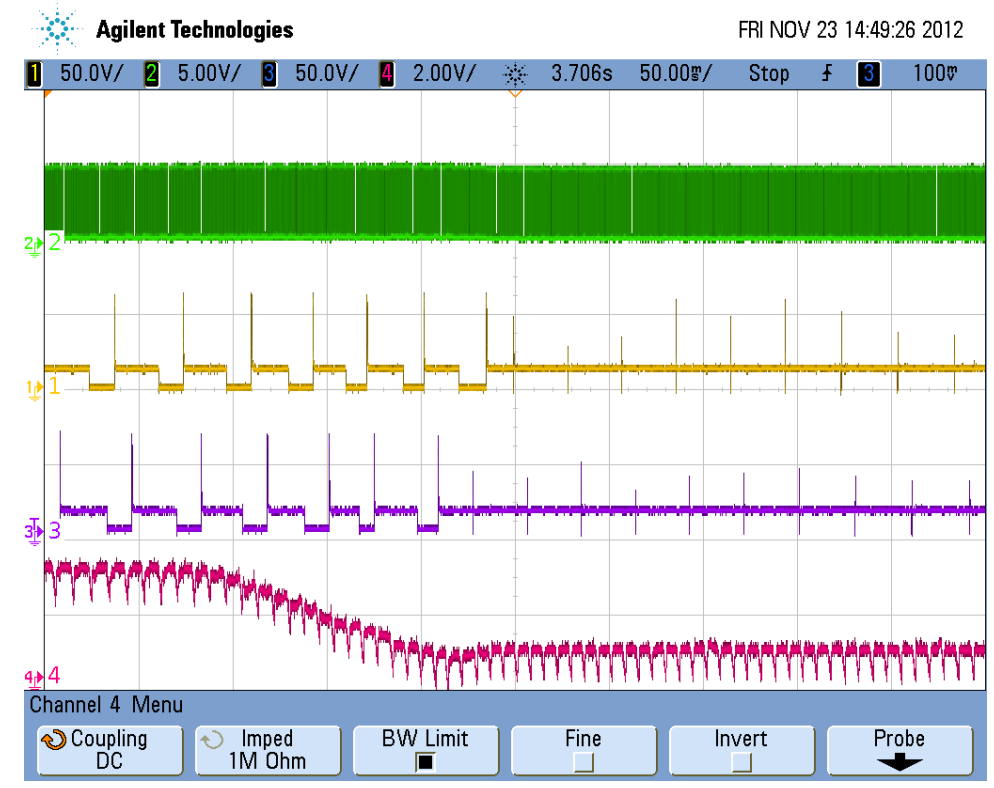

Figura 72 - Sinal capturado no osciloscópio em regimes de aceleração e desaceleração do motor.

Enquanto o pedal de aceleração permaneceu pressionado é possível notar que o tempo de injeção de combustível está grande, aproximadamente 13ms. No momento em que o pedal do acelerador é desacionado inicia-se um processo de desaceleração e juntamente a isso a estratégia de corte da injeção de combustível é iniciada com o intuito de minimizar as emissões de gases e economizar combustível. Essa estratégia é conhecida como cut off e permanece no regime de desaceleração até que o motor atinja a rotação de $1500 \mathrm{rpm}$, retornando a partir de então para a estratégia de marcha lenta ou aceleração dependendo se o pedal do acelerador for pressionado novamente ou não. 


\section{CONCLUSÃO}

O projeto de desenvolvimento de uma plataforma de gerenciamento eletrônico para controlar motores a combustão interna cumpriu com sua meta inicial de desenvolver uma plataforma confiável que adquirisse e processasse sinais de sensores automotivos adequadamente e gerenciasse todas as funções principais de um motor a combustão, possibilitando a sua partida e a manutenção do seu funcionamento em regimes de marcha lenta, aceleração e desaceleração em um motor sem carga, sendo o passo principal para possibilitar o controle completo de um motor de um automóvel.

Com o auxílio de um mock-up foi possível testar e validar todo o desenvolvimento do hardware e software de uma unidade de gerenciamento eletrônico de um motor a combustão interna e com isso criar uma plataforma que poderá ser utilizada para futuros desenvolvimentos de soluções tecnológicas na área de eletrônica embarcada. Sendo um importante avanço para o grupo de pesquisa formado por alunos e professores da FATEC Santo André e da EPUSP, criando uma grande versatilidade de aplicações de novas tecnologias, tais como: estudo da corrente iônica das velas de ignição, estudo do tratamento do sinal do sensor de detonação, etc.

Bem como juntamente com o mock-up e a intersecção da ECU original foi possível criar uma plataforma onde será possível o desenvolvimento de recursos humanos qualificado para atuar no mercado automotivo na área de gerenciamento eletrônico de motores a combustão interna do ciclo Otto.

Contudo essa plataforma - mock-up, interseccionamento e ECU desenvolvida ficarão disponibilizadas no espaço físico da FATEC Santo André para a utilização em disciplinas tanto do curso de Tecnologia em Eletrônica Automotiva ministrados na FATEC Santo André como para disciplinas do curso de Engenharia Elétrica da Escola Politécnica da USP. Podendo inclusive servir de ferramenta para os alunos dessas universidades no desenvolvimento de trabalhos de conclusão do curso ou teses de mestrados e doutorados. 


\subsection{PROPOSTAS FUTURAS}

Como contribuições futuras para esse trabalho a seguir estão algumas sugestões de possíveis trabalhos e evoluções que o sistema desenvolvido nessa tese não abordou:

- Desenvolvimento de um sistema de controle robusto para atuar na válvula borboleta.

- Aplicação da unidade de gerenciamento eletrônico desenvolvida em um automóvel com o motor submetido à carga, com a intenção de simular situações reais de utilização diária de um motor.

- Implementação do software no bloco de comunicação/diagnose.

- Controle do sistema de injeção e ignição com a malha fechada através da sonda lambda, conseguindo assim utilizar tanto etanol quanto gasolina como combustível para prover energia química à combustão.

- Aprimoramento nos mapas de injeção e ignição para outros tipos de motores, tornando o sistema auto adaptativo.

- Aprimoramento dessa unidade de gerenciamento eletrônico para motores de combustão interna do ciclo Otto turbo alimentados, com a intenção de controlar a taxa de compressão e variá-la conforme o combustível utilizado, a fim de entregar a máxima potência do motor independente do combustível utilizado.

- Otimização da curva de potência e torque de motores a combustão interna. 


\section{REFERÊNCIAS BIBLIOGRÁFICAS}

AMEY, Robert George. Automotive component innovation: development and diffusion of engine management technologies. Gainesville: Technovation,1995. $13 p$

BANEY, W.; CHILCOTT, D.; LONG, S.. A Comparison Between Micromachined Piezoresistive and Capacitive Pressure Sensors. Cleveland: Sae, 1997. 6 p.

BEREISA, Jonas. Applications of Microcomputers in Automotive Electronics. IEEE, 1983. 10 p.

BOSH. Air-mass meters Datasheet. Bosh, 2010. 4 p.

BOSCH. Automotive electric;electronic systems. 2.ed.. Warrendale, P.A, 1995.

BOSCH (Brasil). Manual de Tecnologia Automotiva. 25. ed. São Paulo: Edgar Blücher, 2004. $1231 \mathrm{p}$.

BOSH. Pressure Sensors Datasheet. Bosh, 2010. 13 p.

BOSH. Technische Kundenunterlage. Bosh, 2010. 23 p.

CÂMARA, Júlio César Chaves. Monitoramento eletrônico da mistura ar/combustível em motores de combustão interna ciclo Otto. Salvador: Escola Politécnica, Universidade Federal da Bahia, 2006. $169 p$

CHOU, Tsung-lin; CHU, Chen-hung; LIN, Chun-te. Sensitivity analysis of packging effect of silicon-based piezoresistive pressure sensor. Taiwan: Sensors And Actuators, 2009. 10 p.

DAI, F.; FELGER, W.; FRÜHAUF, T. Virtual Prototyping Exemples for Automotive Industries. Fraunhofer Institute for Computer Graphics (IGD).

DELPHI. ETC air Control Valve (ETC-ACV): Application Manual. Rochester: Delphi, 2003. 105 p

DIAS, Bruno Martin de Alcântara. Plataforma Didática de Injeção Eletrônica para Controle de Motores de Combustão Interna. Santo André:Faculdade de Tecnologia, FATEC Santo André, 2011. $77 \mathrm{p}$.

FIAT TREINAMENTO ASSISTENCIAL. Sistema de Injeção/Ignição IAW-IAB. Betim, 1996. 66p.

FLINK, James, The Automobile Age. Massachusetts, Halliday Lithograph, 1990. 440p 
FREESCALE. A Throttle Control H-Bridge (Data sheet MC33926). Colorado: Freescale Semiconductor, 2007. $25 p$

FREESCALE. Automotive Engine Control IC (Data sheet MC33810). Colorado: Freescale Semiconductor, 2011. $37 \mathrm{p}$

FREESCALE. Multiple Switch Detection Interface with Supressed Wake-up (Data sheet MC33972). Colorado: Freescale Semiconductor, 2007. 29 p

GONZÁLEZ, Ernesto Gutiérrez; FLÓREZ, Jesuús Alvarez; ARAB, Sebastién. Development of the management strategies of the ECU for an internal combustion engine: Computer simulation. Barcelona: Polytechnical University Of Catalunya, 2007. 18 p.

HONEYWELL INC.. Hall Effect Sensing and Aplication: Hall Effect Sensors: Honeywell, 2002.

KANG, Kern Y.; BACK, Je H.. Turbulence characteristics of tumble flow in a four-valve engine. Coréia do Sul: Experimental Thermal And Fluid Science, 1998. 13 p.

MATTAR, George. 1958 DeSoto Electrojector - First Electronic Fuel Injection. USA: Hemmings Motor News, 2005. 6 p.

MICROCHIP. PIC18fXX2 Data Sheet. Estados Unidos da América: Microchip Technology Incorporated, 2006. $332 \mathrm{p}$.

MILHOR, Carlos Eduardo. Sistema de Desenvolvimento para Controle Eletrônico dos Motores de Combustão Interna Ciclo Otto. São Carlos: Escola de Engenharia de São Carlos, Universidade de São Paulo, 2002. 86 p.

MORAN, Michael J. et al. Engenharia de Sistemas Térmicos: Termodinâmica, Mecânica dos Fluidos e Transferência de Calor. Rio de Janeiro: Livros Técnicos e Científicos Editora S.a, 2005. $604 \mathrm{p}$.

MORAN, Michael J.; SHAPIRO, Howard N.. Fundamentos de Termodinámica Técnica. 2. ed. Barcelona: Reverté, 2004. 875 p.

PUJATTI, Fabrício José Pacheco. Desenvolvimento de um Sistema de Gerenciamento Eletrônico para Motore de Ignição por Centelha. Belo Horizonte: Universidade Federal de Minas Gerais, 2007. 215 p. 
RIBBENS, Willian B.. Understanding Automotive Eletronics. 5. ed. Boston: Butterworthheinemann, 1998. $446 \mathrm{p}$.

SCHÜTZER, I. K. Implantação do "Digital Mockup" na Indústria Automobilística, Piracicaba, p. 10, 2002.

SELEÇÕES DO READER'S DIGEST (Portugal) (Ed.). O livro do Automóvel. Lisboa: Composto em Lisgráfica, 1976. $379 \mathrm{p}$.

SILVIO. Máquina Térmicas: Apostila de Motores de Combustão Interna. Brasil: Unijuí, 2000. 100 p.

SOARES, A. M. F.; SACARPINETTI, V. S. Unidade eletrônica de controle de um motor a combustão: Projeto Otto. São Paulo: Escola Politécnica da Universidade de São Paulo, 2012. 116 p.

TEXAS INSTRUMENTS. LM1815 Adaptive Variable Reluctance Sensor Amplifier. Texas: Texas Instruments, 2005. $17 \mathrm{p}$

TOYOTA MOTOR SALES. Fuel Systems \#2 - Injection Duration Controls. USA. 2008, 11 p.

TOYOTA, Technical Training. Introduction to Engine Control Systems. Toyota, 2008, 349 p.

TRIETLEY, Harry L.. Transducers In Mechanical And Electronic Design. United States: Taylor \& Francis Inc, 1986. $392 \mathrm{p}$.

VOLKSWAGEN (Brasil). Sistema de Gerenciamaneto de Motores Aspirados. São Bernardo do Campo: Academia Volkswagen, 2009. 96 p.

VOLTI, Bulti, Cars and Cultures - The Life Story of a Thechnology. United States of America, Greenwood Technographies, 2004.179p

W. J. Envenenado, 2013. Disponivel em:

<//www.envenenado.com.br/howwork/injecao/injecao.html >. Acesso em: 29 abr. 2013. 


\section{ANEXO A - HARDWARE}

\section{A 1 PIC DE GERENCIAMENTO}

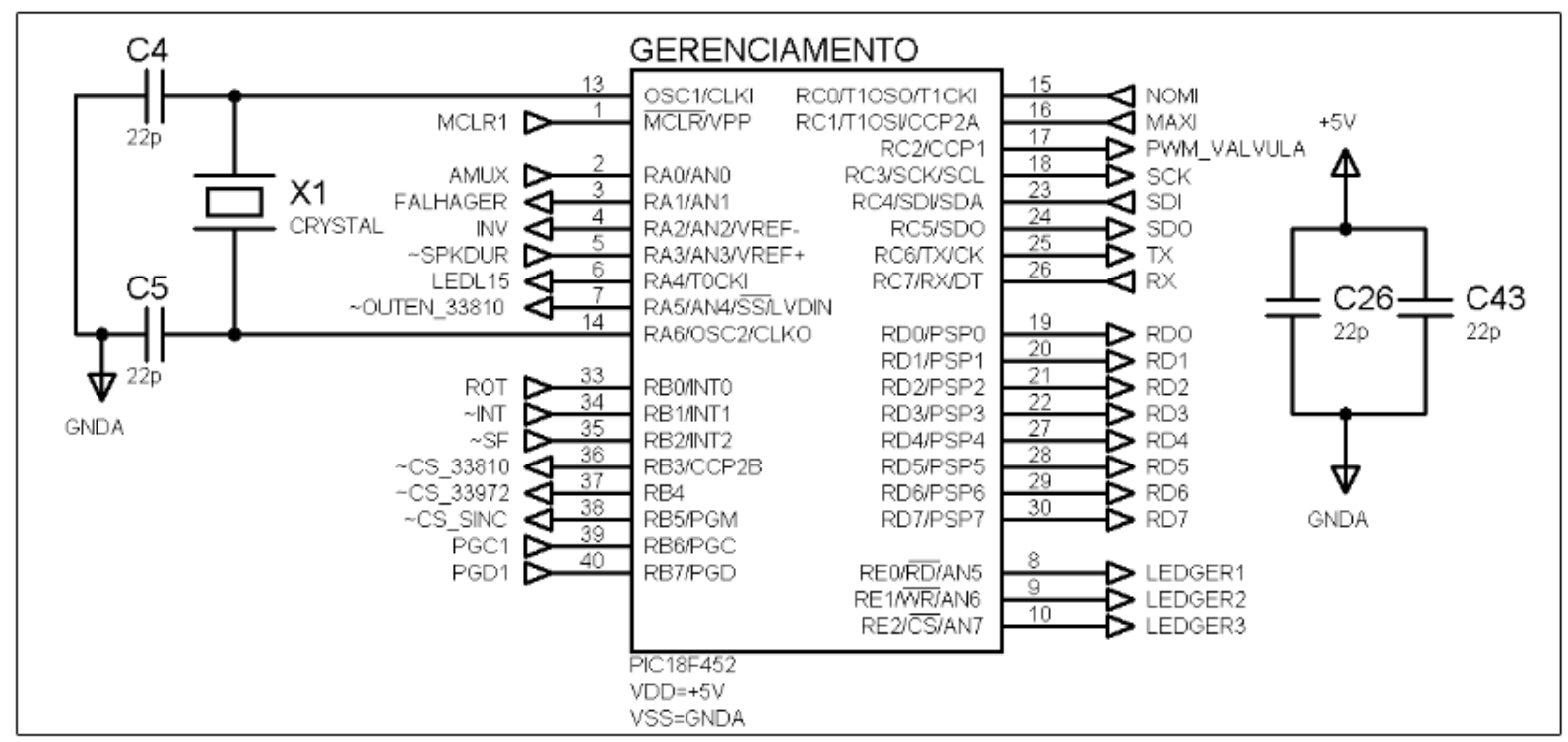

\section{A 2 PIC DE SINCRONISMO}

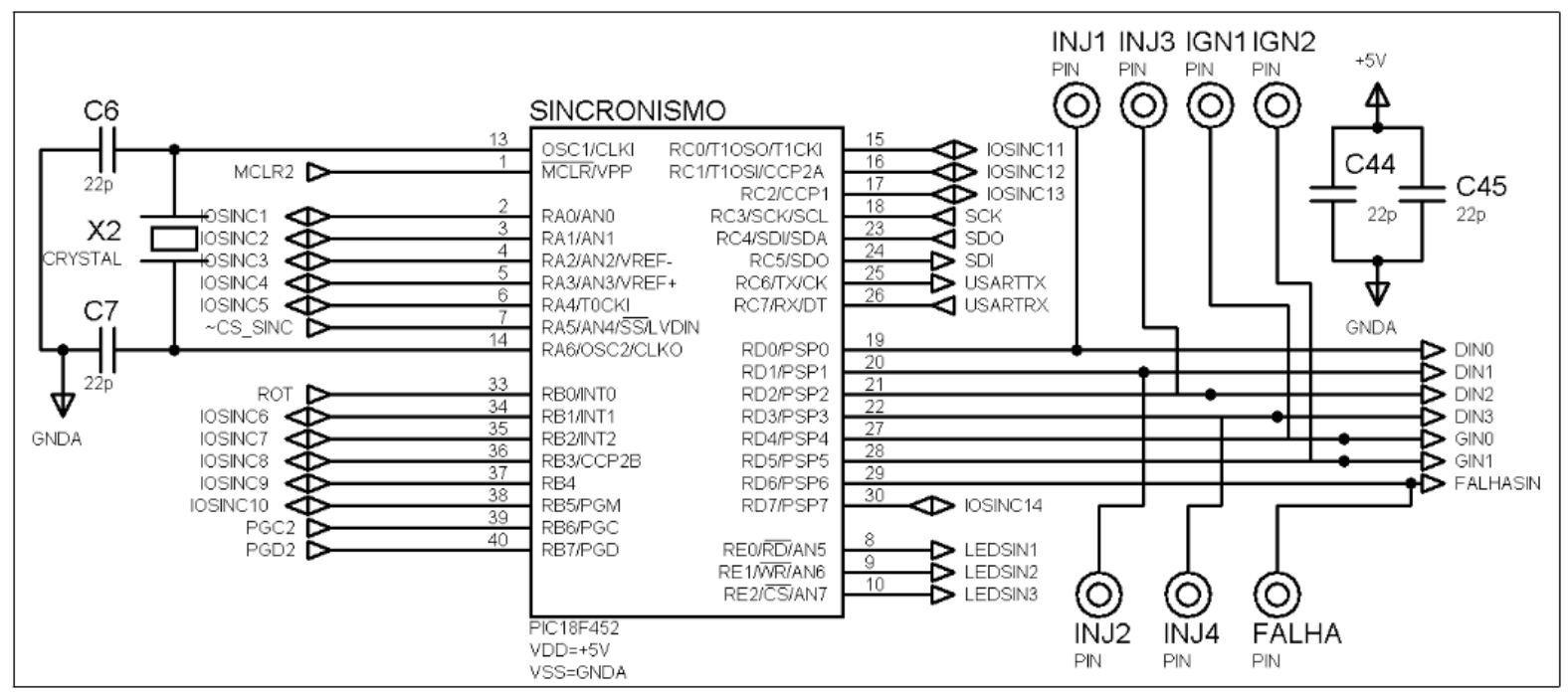




\section{A 3 PIC DE COMUNICAÇÃO}

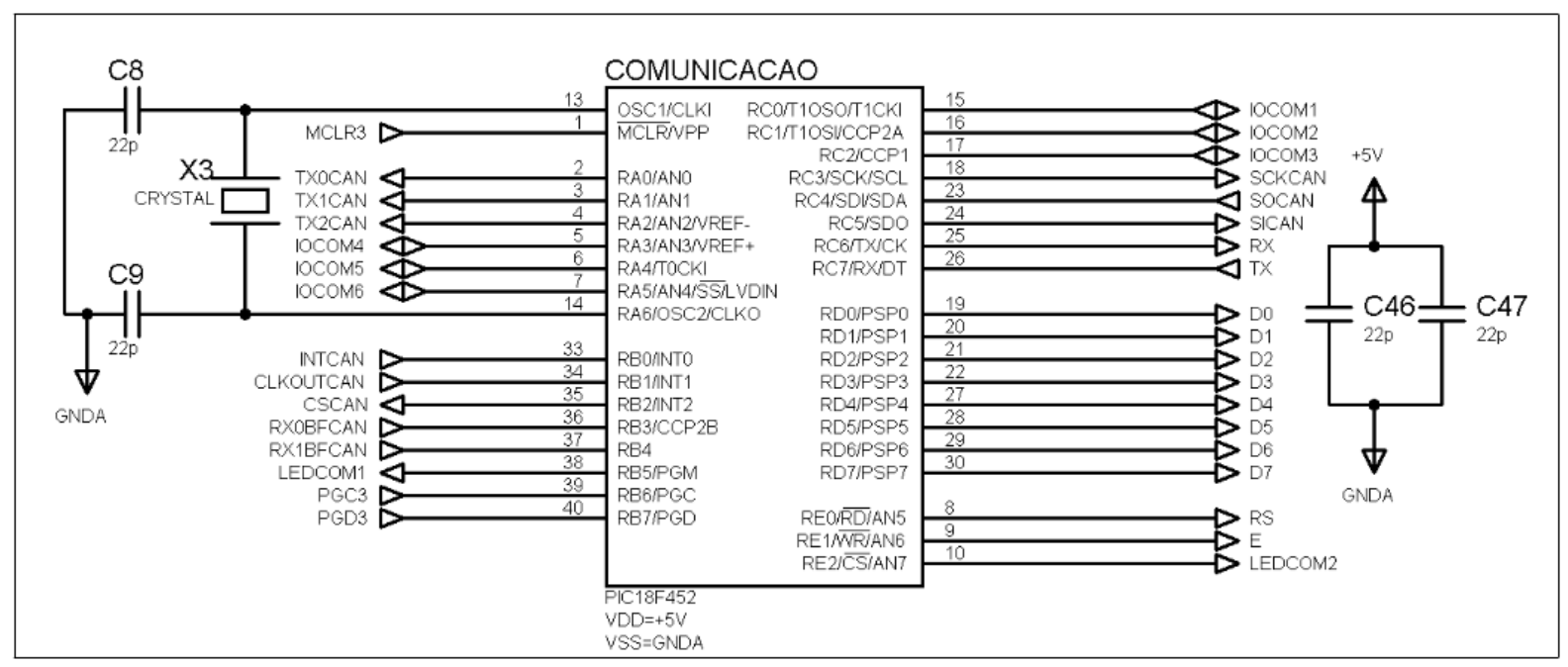

\section{A 4 ALIMENTAÇÃO DO CIRCUITO}

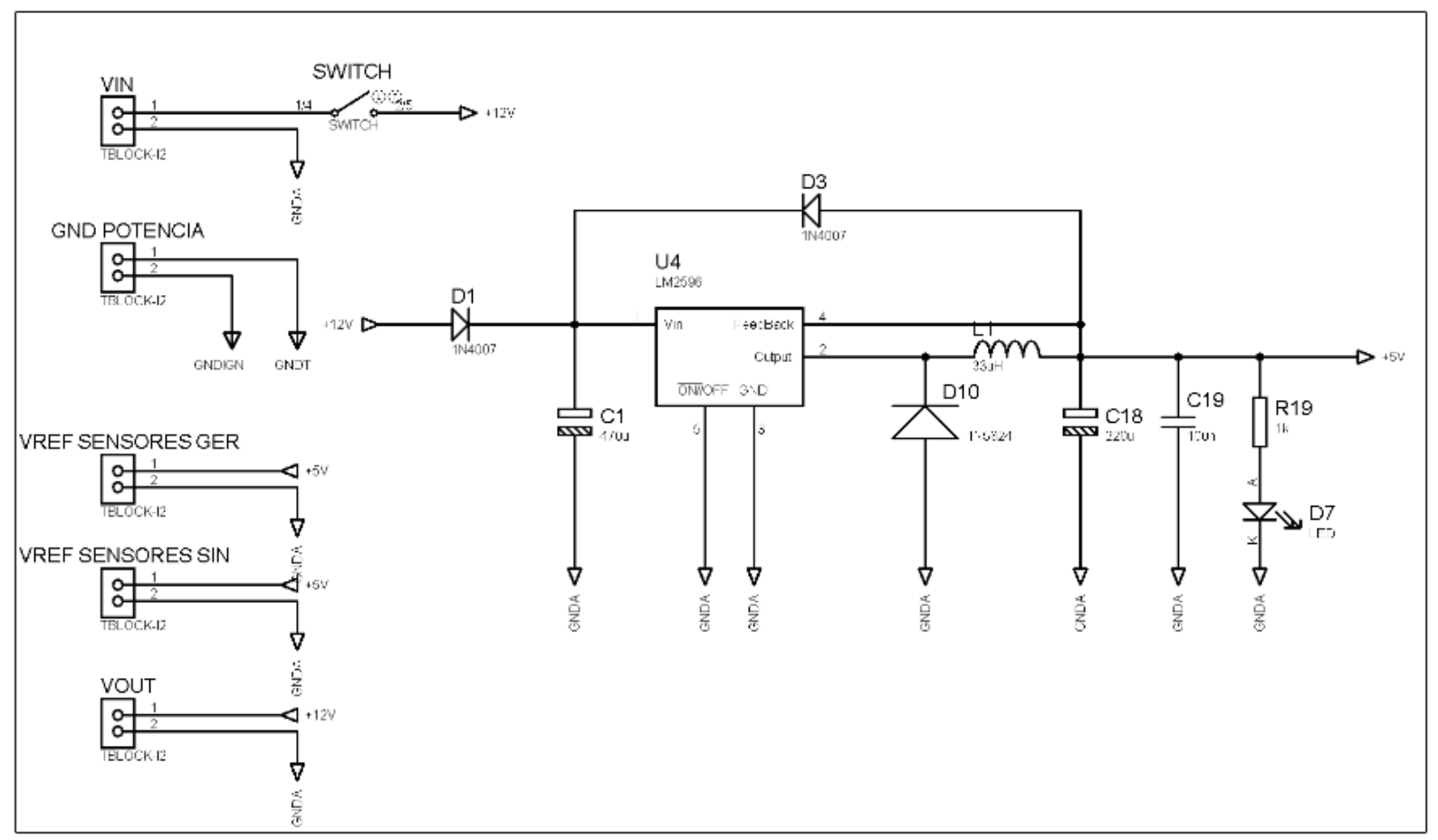




\section{A 5 BARRAMENTO CAN}

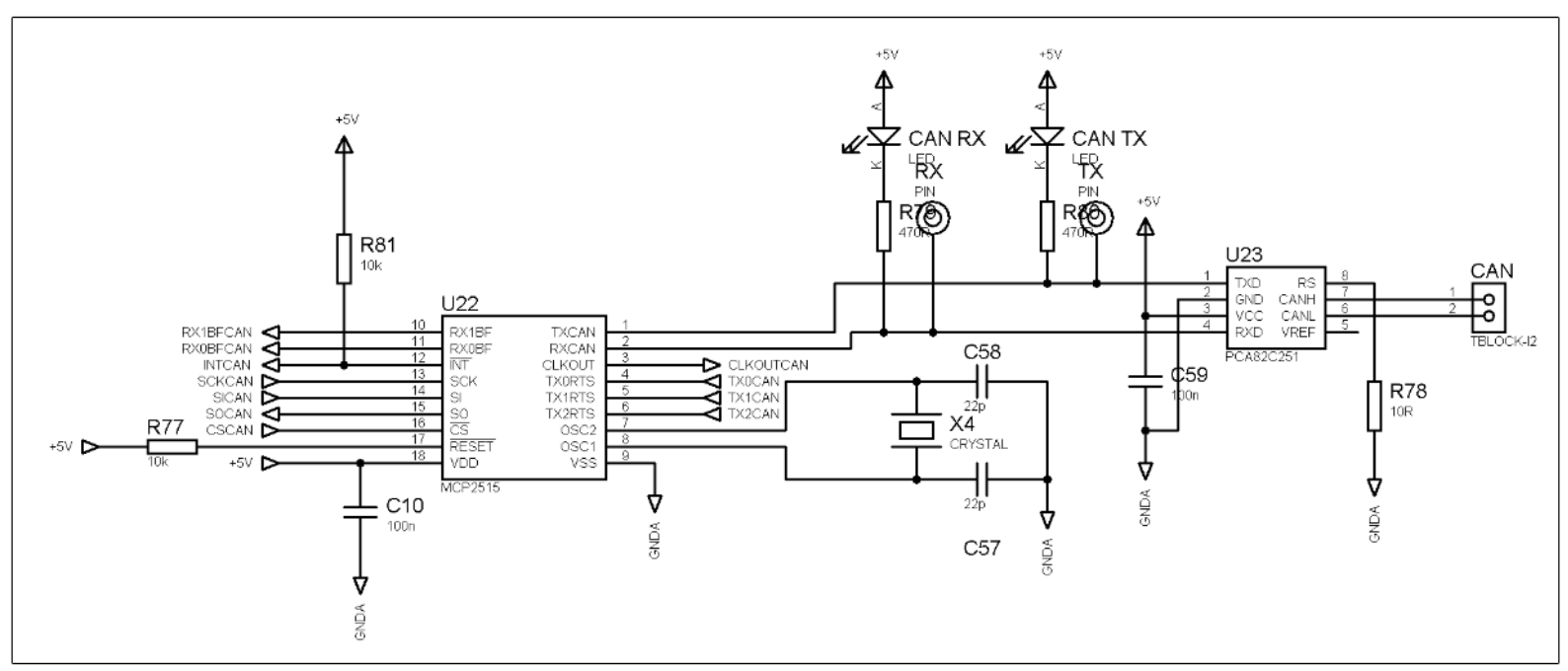

\section{A 6 CIRCUITO DE RESET}

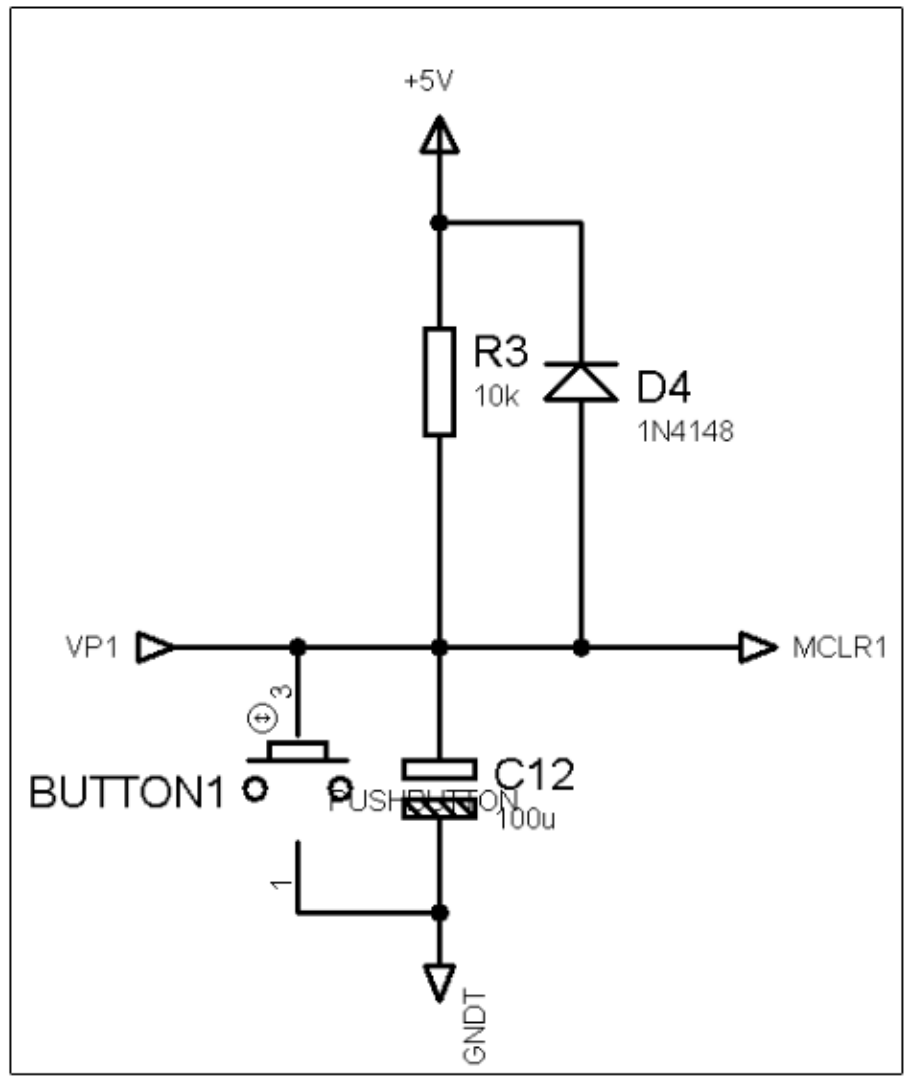


A 7 SINAIS DE ENTRADAS

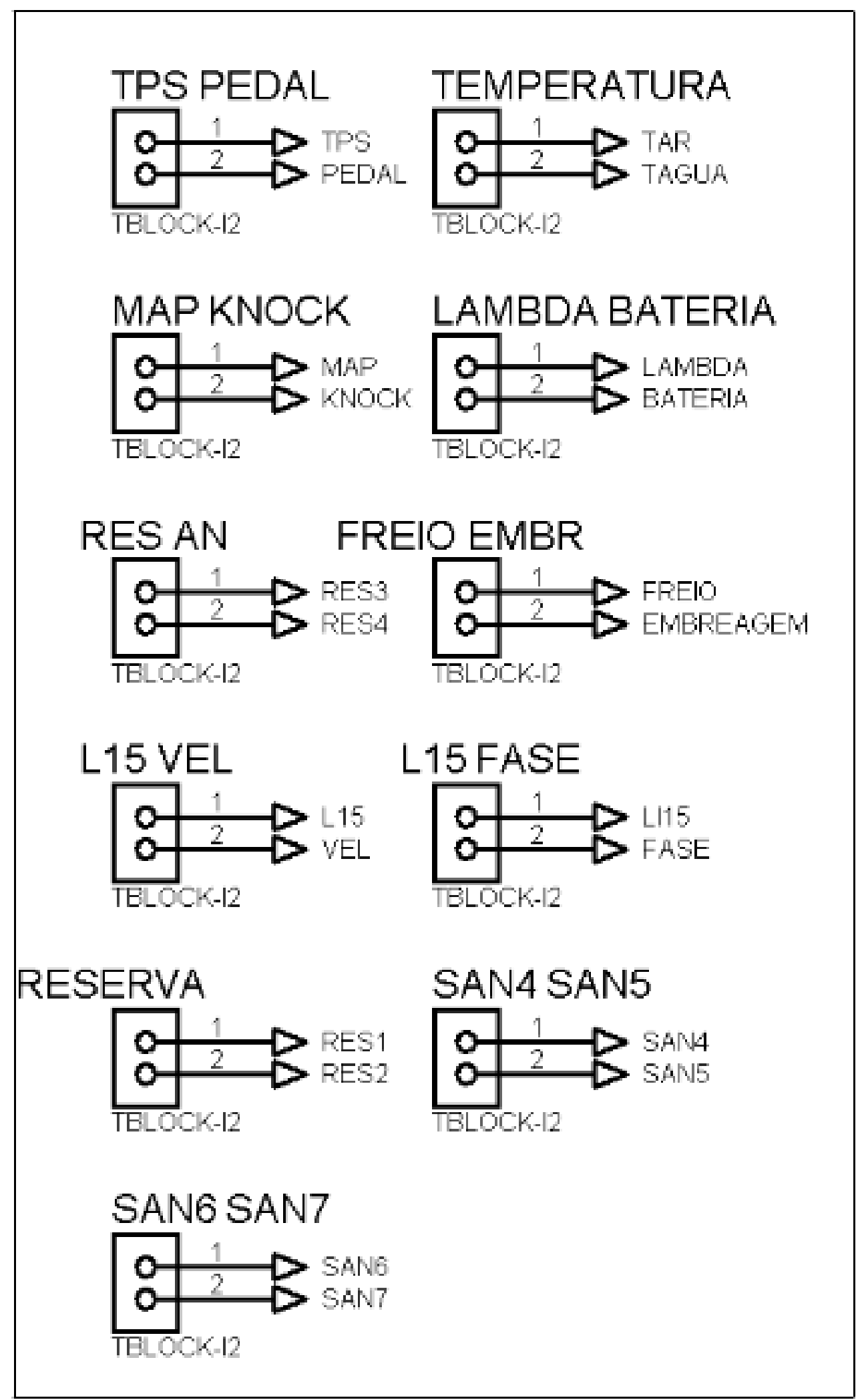




\section{A 8 SINAIS DE SAIIDA}

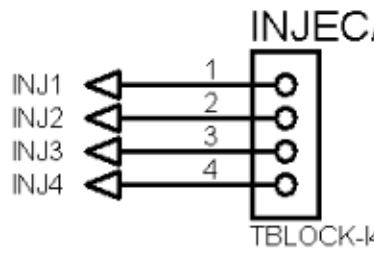

MOTOR BORBOLETA
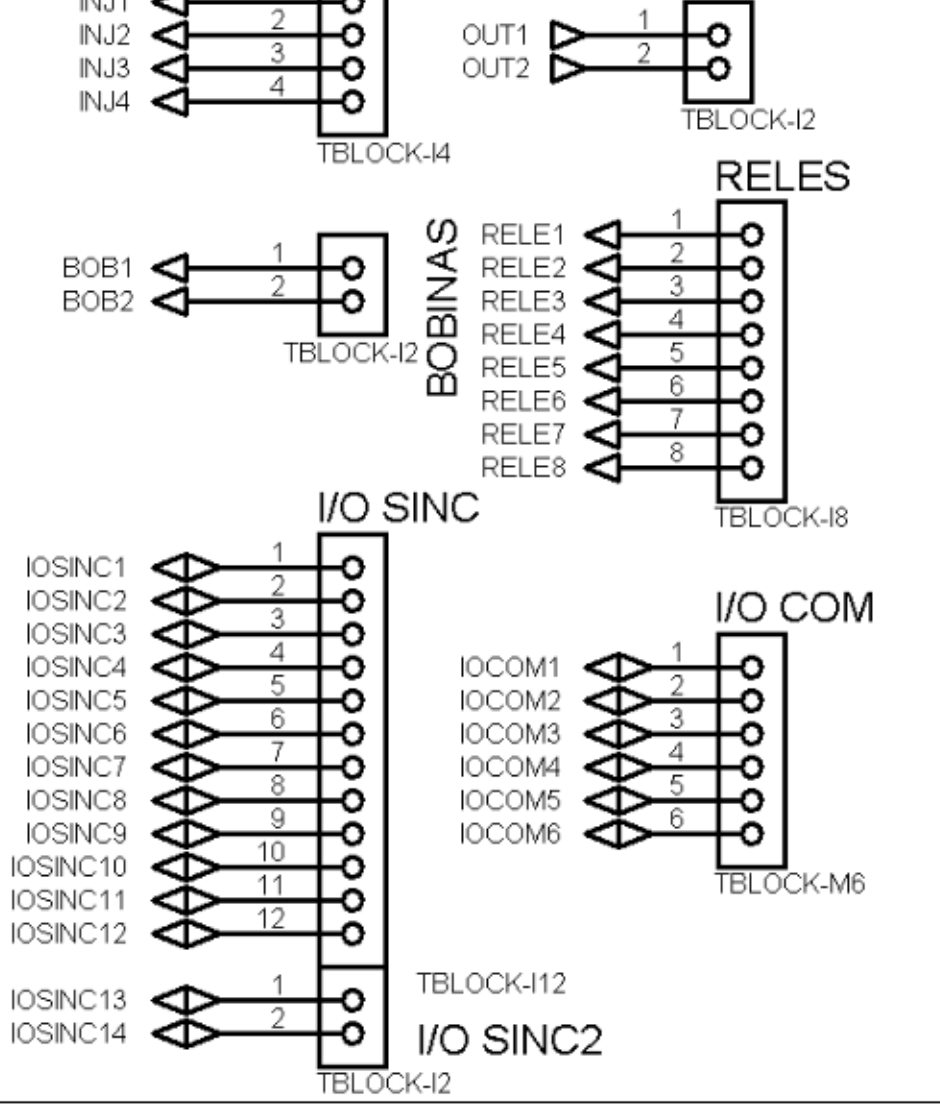

A 9 LCD

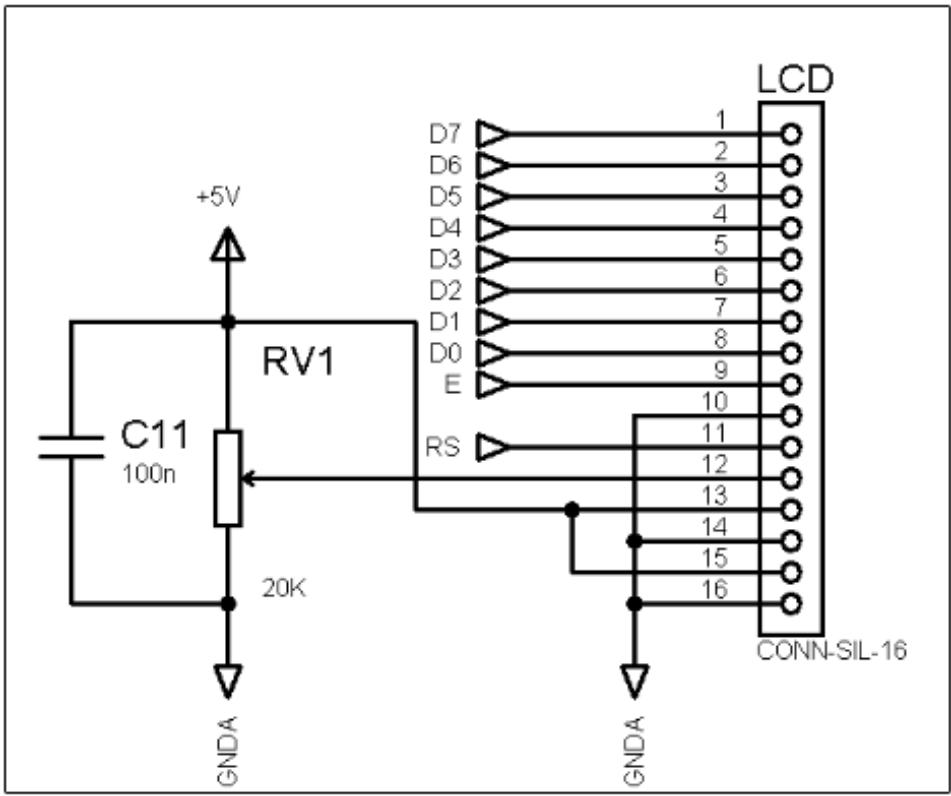




\section{A 10 LEDs}

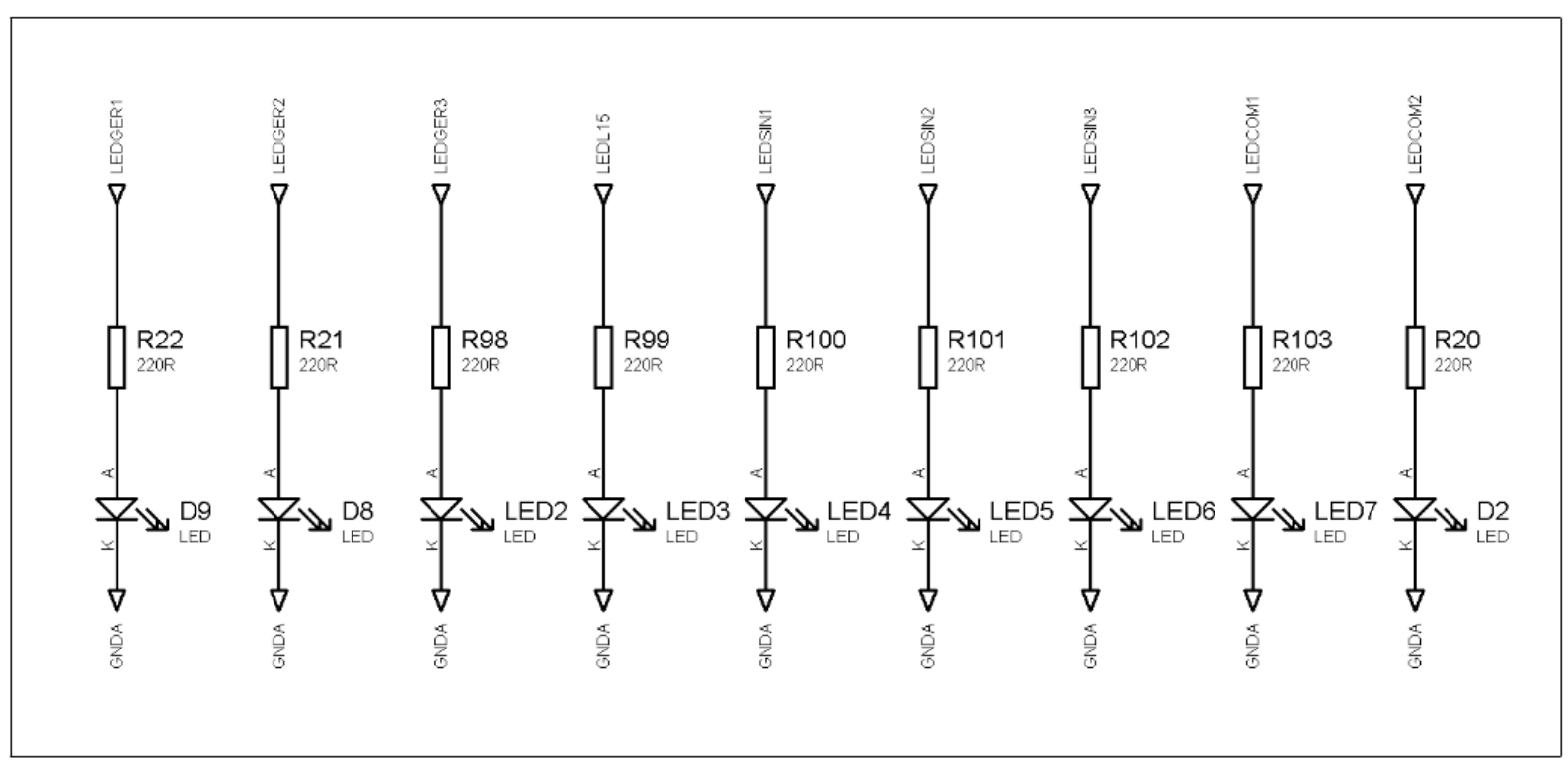

\section{A 11 LM1815}

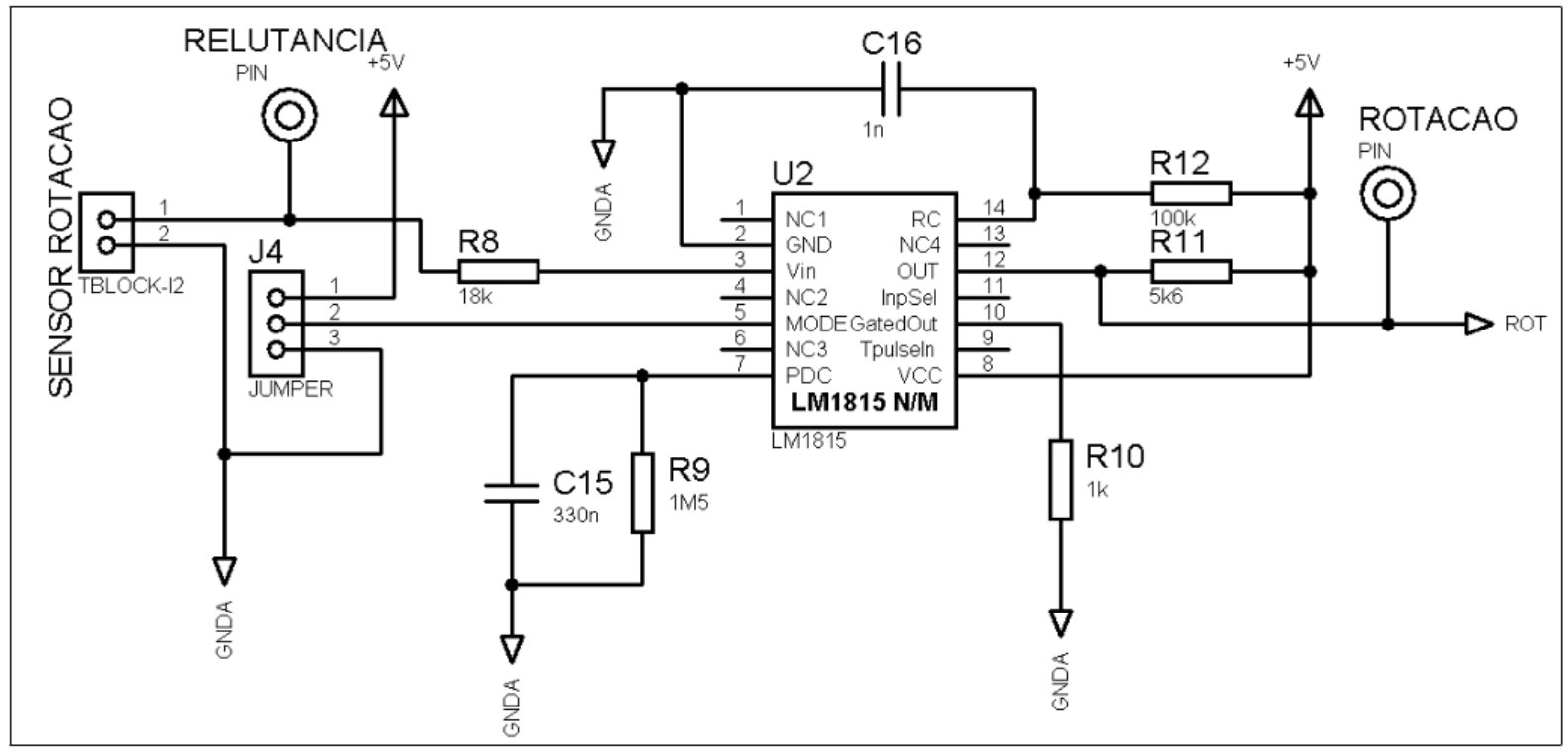




\section{A 12 MC33810}

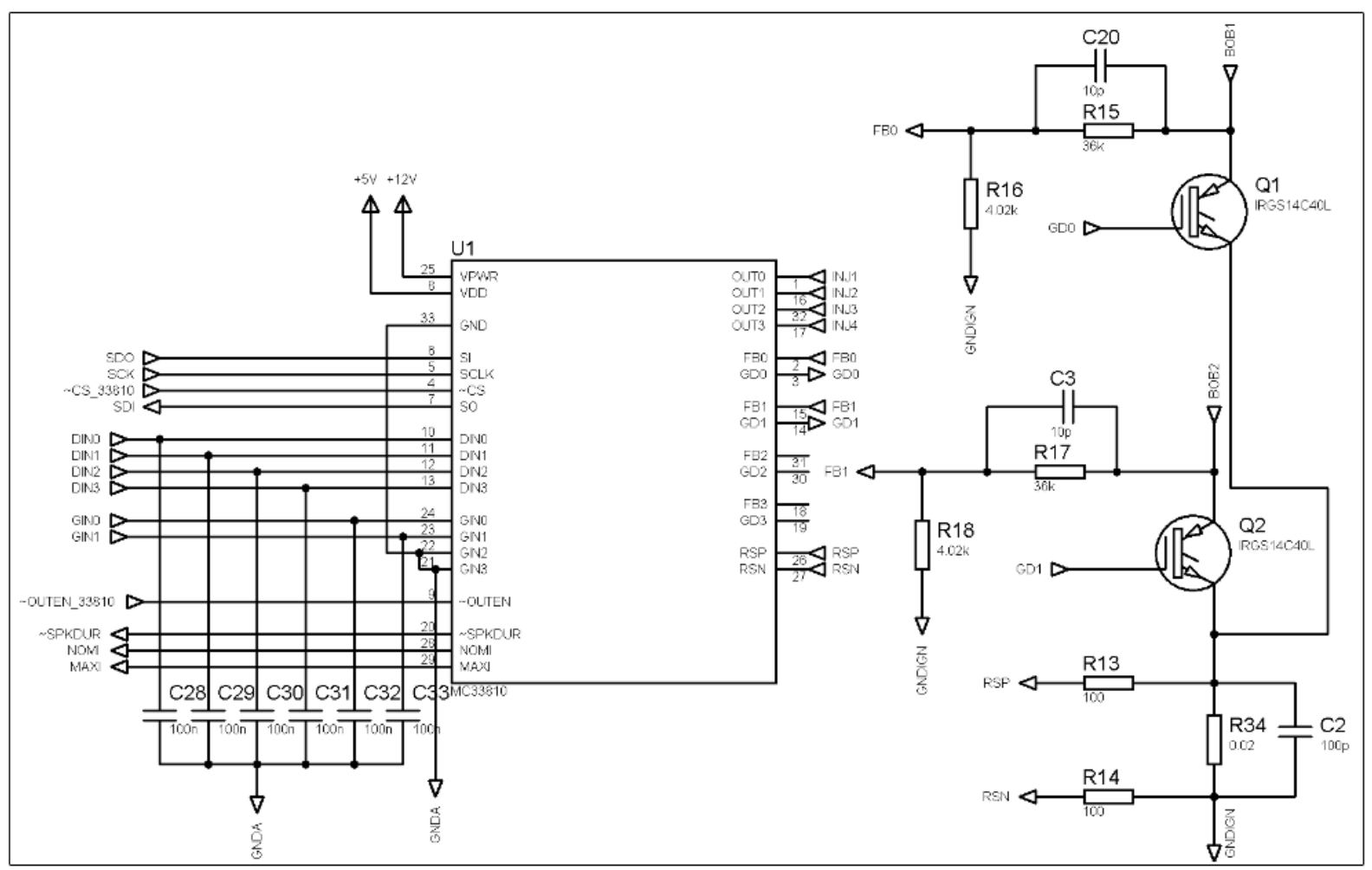

\section{A 13 MC33926}

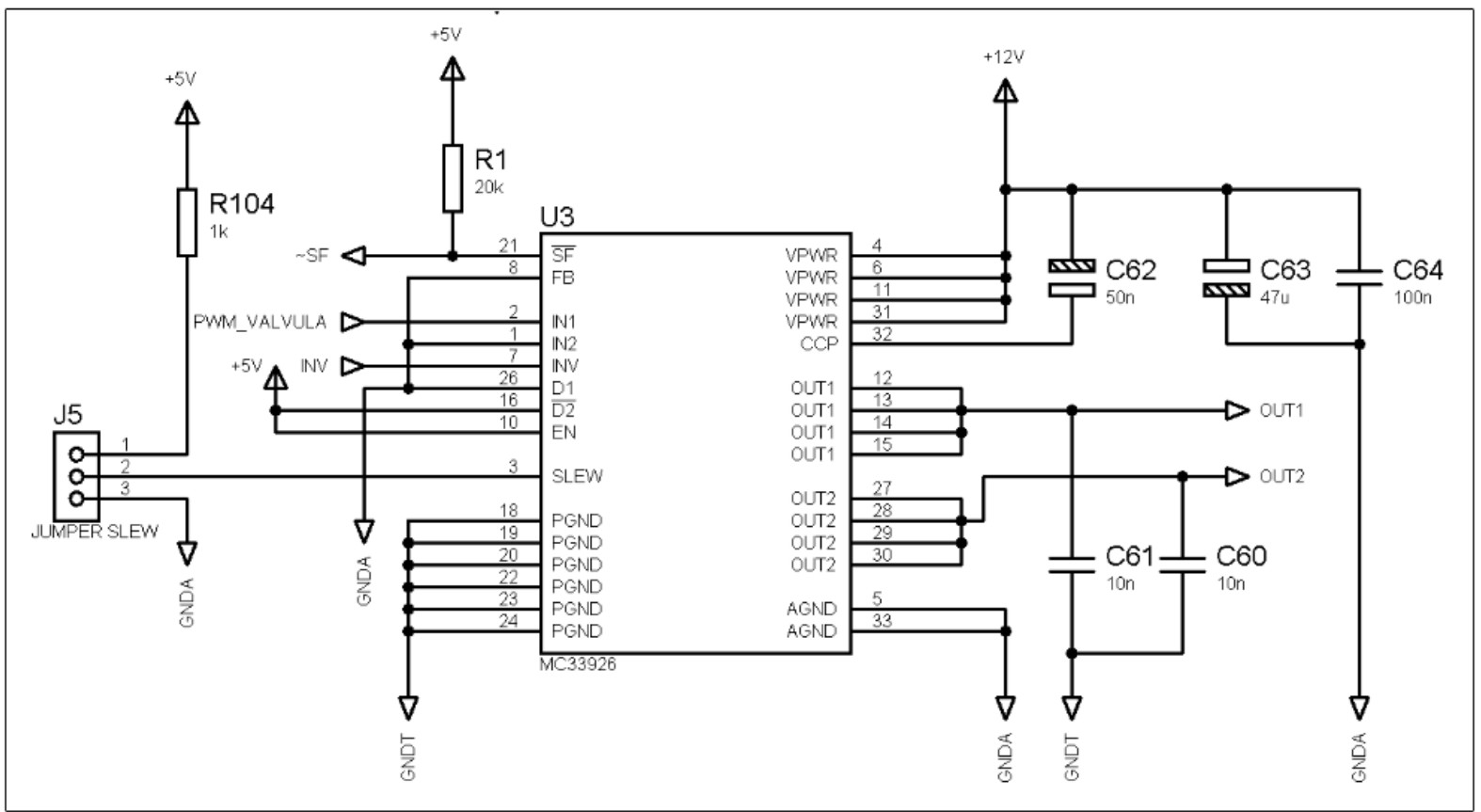


A 14 MC33972

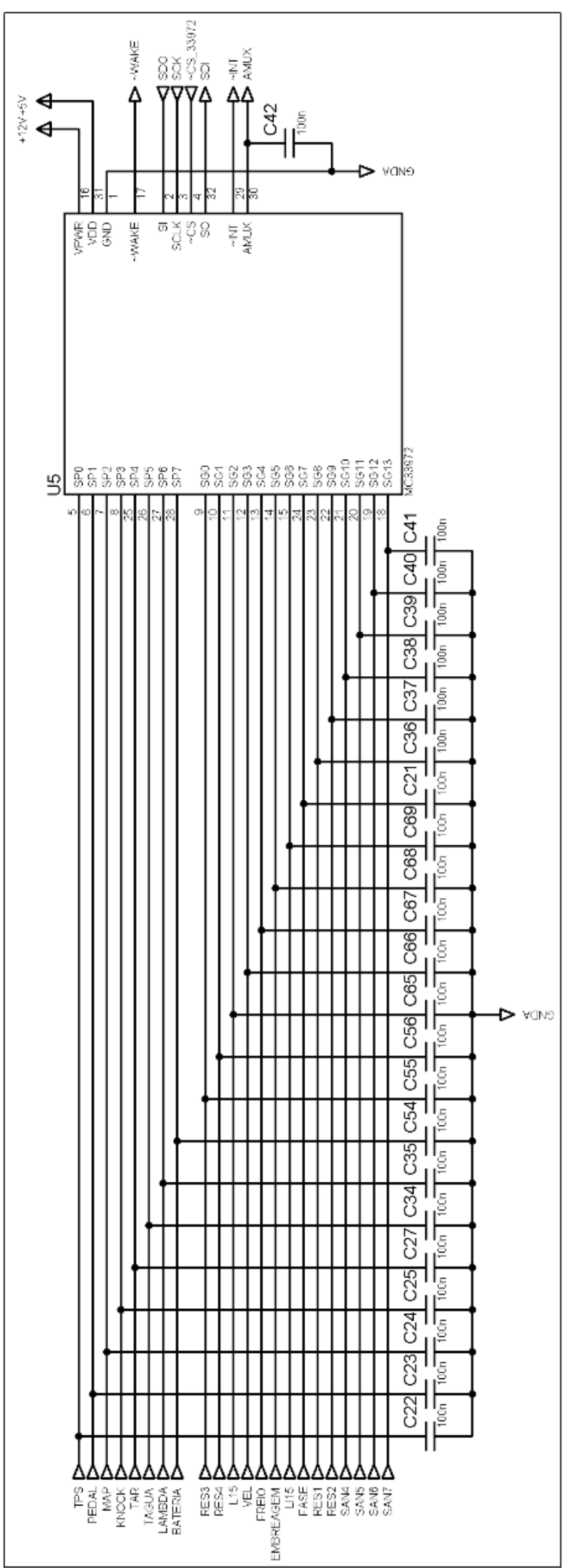




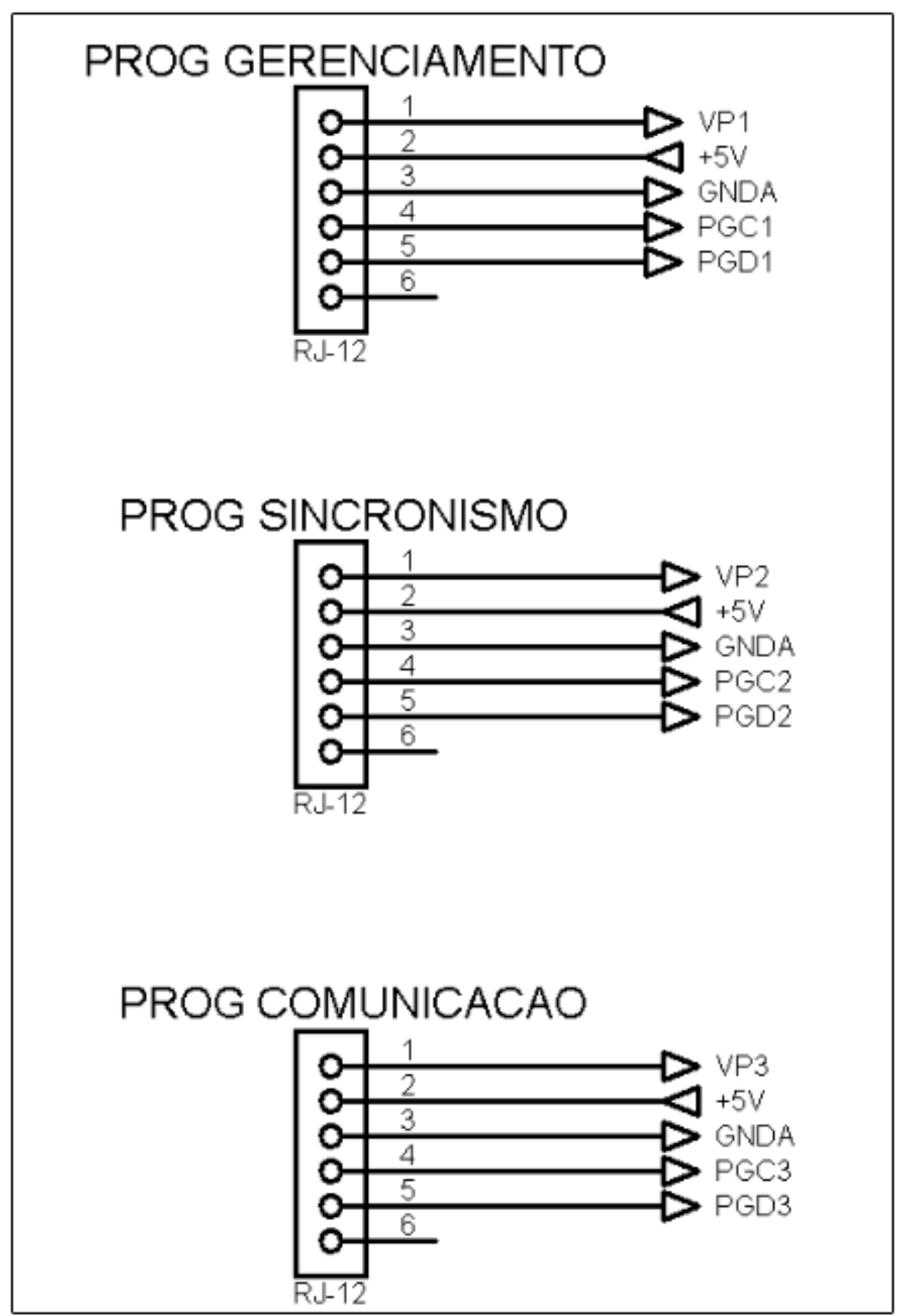

\section{A 16 RELÉS}

Os relés são controlados pela porta RD do PIC de gerenciamento, partindo da porta RD0 que comanda o relé 1, seguindo até a porta RD7 responsável por controlar o relé 8. 


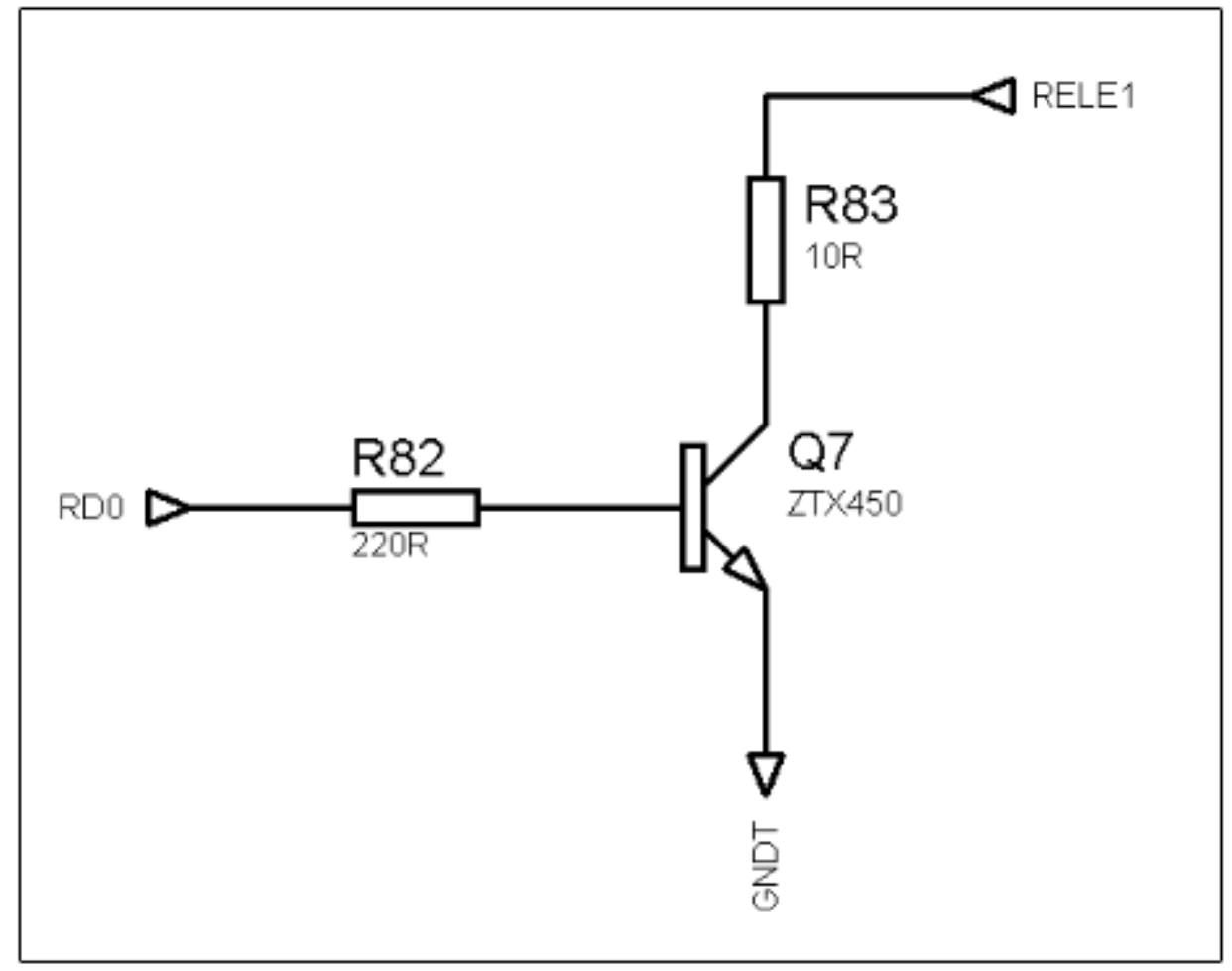




\section{ANEXO B - SOFTWARE}

\section{B 1 GERENCIAMENTO - Função Principal}

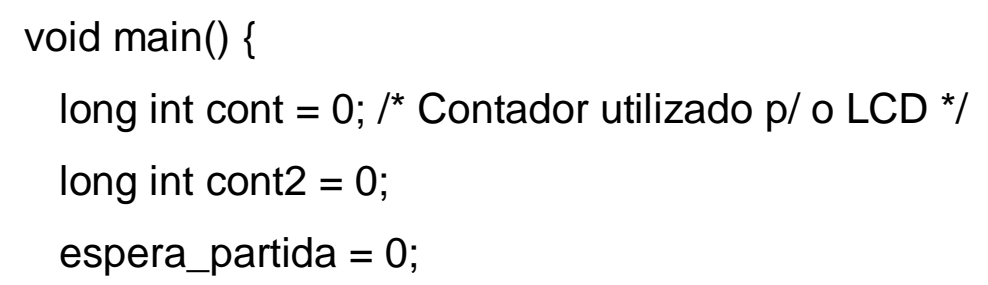

/* Configuração das Portas */

set_tris_a(0b00001001);

set_tris_b(0b11000111);

set_tris_c(0b10010011);

set_tris_d(0b00000000);

set_tris_e(0b00000000);

/* Configuração inicial de alguns parâmetros */

setup_adc_ports(ANO);

setup_adc(ADC_CLOCK_INTERNAL);

//setup_adc(ADC_CLOCK_DIV_2);

setup_psp(PSP_DISABLED);

setup_spi(SPI_MASTER|SPI_L_TO_H|SPI_CLK_DIV_4|SPI_XMIT_L_TO_H);

//setup_spi(SPI_MASTER|SPI_H_TO_LISPI_CLK_DIV_4|SPI_XMIT_L_TO_H);

setup_wdt(WDT_OFF);

setup_ccp1(CCP_PWM);

$/{ }^{*}$ Configuração inicial dos Timers */

setup_timer_0(RTCC_INTERNAL|RTCC_DIV_1); /* 16 bits - Medicao da rotacao * setup_timer_1(T1_INTERNAL|T1_DIV_BY_1); /* 16 bits - Deteccao da falha */ setup_timer_2(T2_DIV_BY_4,100,1); /* Gera o PWM (freq $=12.5 \mathrm{kHz})$ */ setup_timer_3(T3_INTERNAL|T3_DIV_BY_8); //teste para ler pedal //setup_timer_3(T3_disabled); 
set_pwm1_duty(calcula_pwm $(0,100)$ ); //inicia o pino do PWM em zero output_low(INV); /* Desliga reverse - Ponte $\mathrm{H}$ */

output_low(rele_geral);

output_low(rele_bomba);

output_low(rele_mp);

disable_interrupts(GLOBAL);

disable_interrupts(INT_EXT);

${ }^{*}$ Inicializacao das variaveis - Ignicao *

t_low = 0;

t_low_ref $=65535 ; /{ }^{*}$ Garante que o pulso de deteccao so acontecera apos a comparacao do segundo pulso de sinal */

$$
\begin{aligned}
& \text { estouro1 }=0 ; \\
& \text { dente }=0 ; \\
& \text { rotacao }=0 ; \\
& a=b=c=0 ;
\end{aligned}
$$

$I^{*}$ Inicializacao das variaveis - Valvula Borboleta */

$$
\text { control }=0
$$

derivative $=0$;

integral $=0$;

error $=0$;

$\mathrm{Kp}=0.0 ;$

$\mathrm{Kd}=0.0$;

$\mathrm{Ki}=0.0$;

pwm =0;

pwm_min $=0$;

pwm_temp $=0$;

ref $=0$;

quente $=0$;

contagem $=5$; 
modo_inj $=0$;

$\mathrm{L} 15=0$;

temp_ar $=0$;

pressao_ar $=0$;

ruido $=0$;

erro_ign $=0$;

fase_ok $=0$; $/ /$ com 0 por seguranca, pode ser que a fase nao acerte de primeira deteccao_fase $=0$; //com 0 para identificar a fase apos comecar o modo de injeção sequencial

estavel $=0 ; / /$ no inicio espera motor pegar e estabilizar

map $=0$;

linha_15 $=0$;

start $=0$;

limite_fullgroup $=2$; //inicia com 200rpm e depois passa para 600 rpm.

contador $=0$;

cutoff $=0$;

ref_subtracao $=0$;

pisca_leds ()$; /{ }^{*}$ Todos os LEDs ficam apagados apos piscarem */

/*--

/* Selecao do SPI - MC33810 *

output_high(SINAL_SS_SINC);

output_low(SINAL_SS_33810);

output_high(SINAL_SS_33972);

/* Calibracao do Clock - MC33810 */

spi_write16(0b1110000000000000);

output_high(SINAL_SS_33810); 
delay_us(20);

output_low(SINAL_SS_33810); /* Pulso de 32us no CS do SPI */

delay_us(32); $\quad$ /* Requisito de calibracao do MC33810 */

output_high(SINAL_SS_33810);

delay_us(20);

output_low(SINAL_SS_33810); /* Mantem o SPI do MC33810 ativo */

I* SPI Check - MC33810 *

/* OBS: O programa espera a resposta do MC33810 para prosseguir */

while (spi_write_read_16(0b0000111100000000) != 0b0000110100001010);

${ }^{*}$ Led Aceso - Passou pelo SPI Check */

output_high(SINAL_SS_33810);

delay_us(20);

output_low(SINAL_SS_33810);

$1 *$ Modo de Operacao - MC33810 */

spi_write16(0b0001000000000000); /* Setado p/ IGN */

output_high(SINAL_SS_33810);

delay_us(20);

output_low(SINAL_SS_33810);

/* Habilita saidas da ignicao e injecao - MC33810 */

//spi_write16(0b0011000000001111);

output_high(SINAL_SS_33810);

delay_us(20);

output_low(SINAL_SS_33810);

/* Spark command - MC33810 */

spi_write16(0b0100010110101101); // Falta calibrar o SPKDUR!!!

//spi_write16(0b0100010110100001); 
output_high(SINAL_SS_33810);

delay_us(20);

output_low(SINAL_SS_33810);

/* DAC command - MC33810 */

spi_write16(0b0110111111011010);

output_high(SINAL_SS_33810);

delay_us(20);

output_low(SINAL_SS_33810);

/* LSD Fault Command - MC33810 *

spi_write16(0b0010101011111111);

$/{ }^{*}$ Habilita saidas - MC33810 *

output_low(OUTEN_33810);

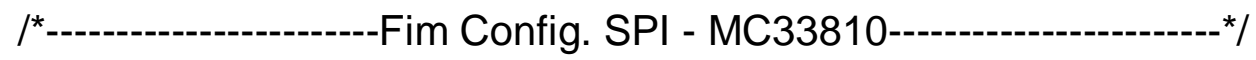

/*----------------Inicio Config. SPI - MC33972---------------*/

output_high(SINAL_SS_SINC);

output_high(SINAL_SS_33810);

output_low(SINAL_SS_33972);

spi_write24(0b011111110000000000000000); /* Reset */

output_high(SINAL_SS_33972);

delay_us(20);

output_low(SINAL_SS_33972);

//spi_write24(0b000001000000000000000000); /* desl wetting current nas SPn */

output_high(SINAL_SS_33972);

/*--- 
// checar funcionamento OK da VB

output_low(INV);

set_pwm1_duty(calcula_pwm $(80,100)$ ); // aberta, PWM 90\%

delay_ms(700); $\quad$ // espera abrir

output_high(SINAL_SS_SINC);

output_high(SINAL_SS_33810);

output_low(SINAL_SS_33972);

spi_write24(0b00000000000001100000000000001111); /* AMUX - SP0 (TPS)*/

output_high(SINAL_SS_SINC);

output_high(SINAL_SS_33810);

output_high(SINAL_SS_33972);

set_adc_channel(0); // porta A0 PIC

delay_us(95);

valvula_aberta $=$ read_adc();

set_pwm1_duty(calcula_pwm $(0,100))$;

delay_ms(400);

output_high(INV);

set_pwm1_duty(calcula_pwm $(50,100))$; // fechada, pwm inv para garantir bom fechamento

delay_ms(500); $\quad$ // espera abrir

output_high(SINAL_SS_SINC);

output_high(SINAL_SS_33810);

output_low(SINAL_SS_33972);

spi_write24(0b00000000000001100000000000001111); /* AMUX - SP0 (TPS)*/

output_high(SINAL_SS_SINC);

output_high(SINAL_SS_33810);

output_high(SINAL_SS_33972);

set_adc_channel(0); // porta A0 PIC

delay_us(60); 


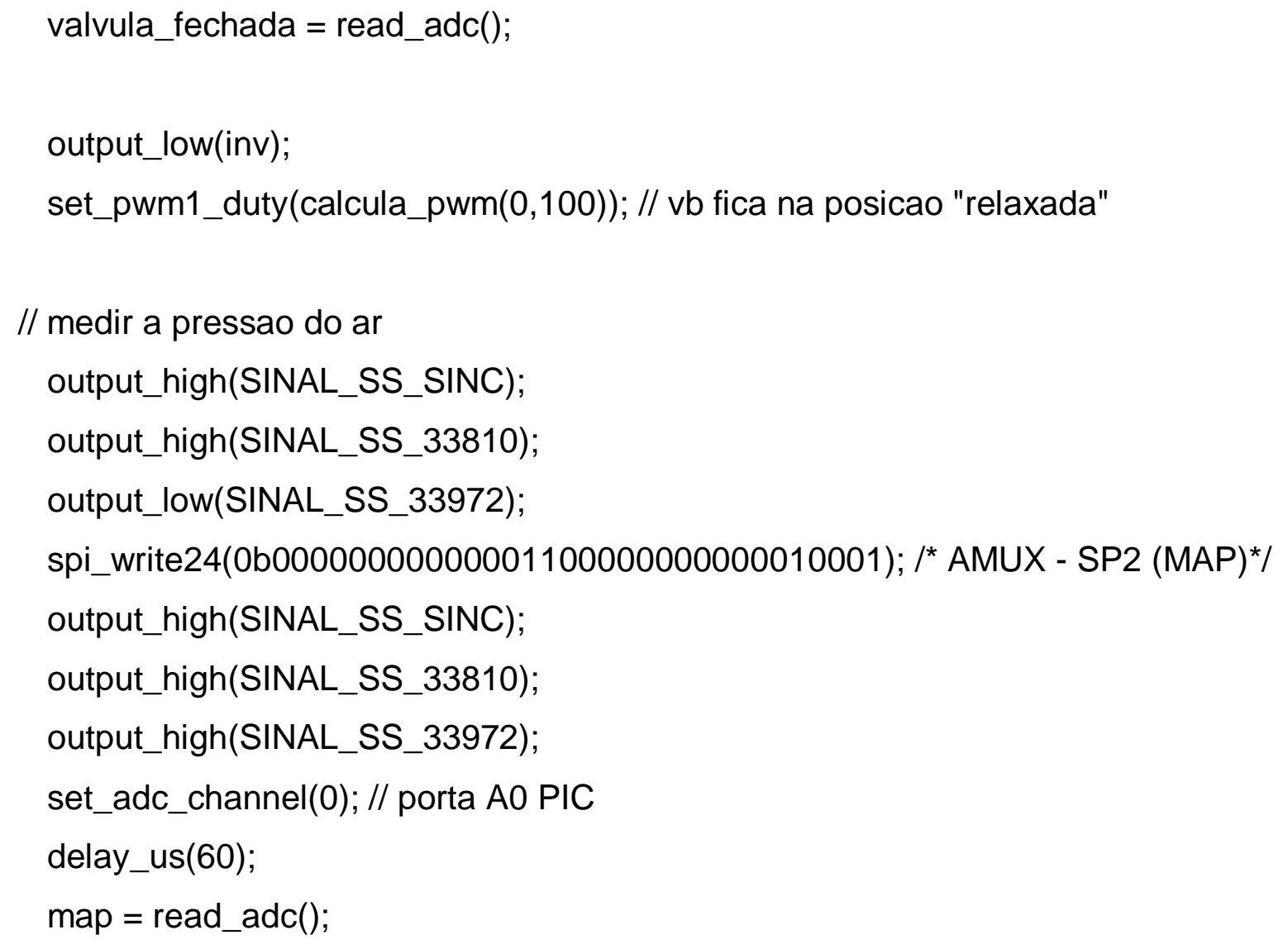

//ligar rele geral output_high(rele_geral);

// ATENCAO: Ligar rele responsavel por controlar injetores+bomba etc... output_high(rele_bomba);

delay_ms(800);

output_low(rele_bomba);

// linha ja pressurizada, desliga e espera partida

/* Habilita interrupcoes *

enable_interrupts(GLOBAL);

enable_interrupts(INT_EXT);

enable_interrupts(INT_RDA);

nivel $=0$;

ext_int_edge(H_TO_L); 
partida $=1 ; / /$ motor regime de partida

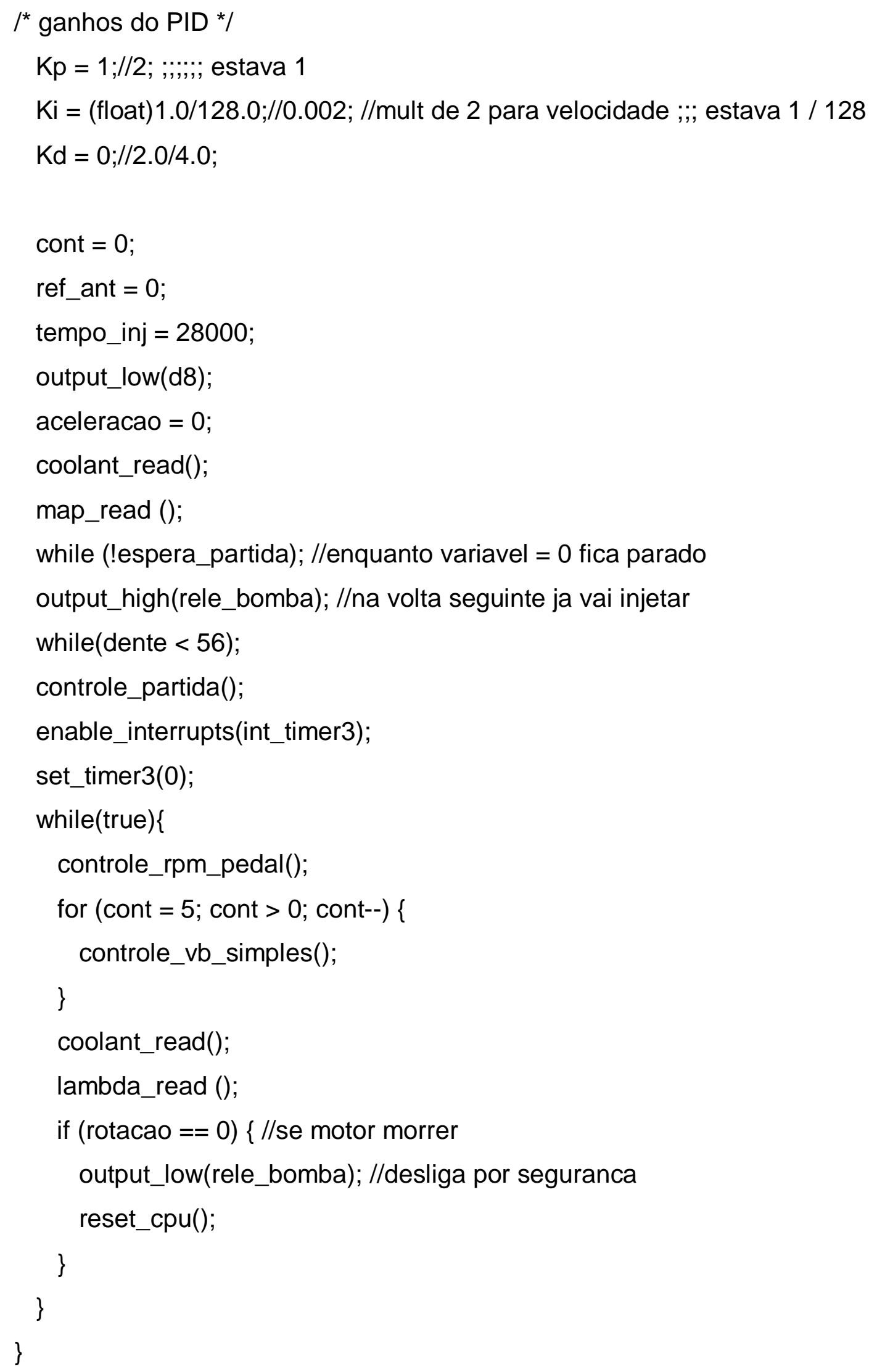




\section{B 2 SINCRONISMO - Função Principal}

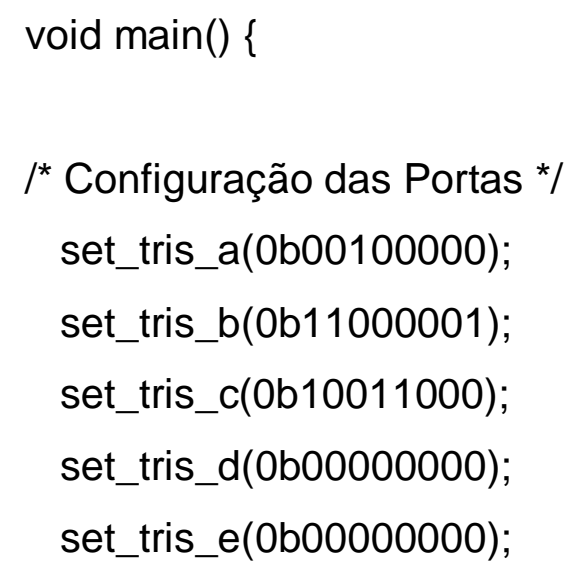

/* Configuração inicial de alguns parâmetros */ setup_adc_ports(NO_ANALOGS);

setup_adc(ADC_OFF);

setup_psp(PSP_DISABLED);

setup_spi(SPI_SLAVE|SPI_L_TO_H); /* Config. como Slave */

//setup_spi(SPI_SLAVE|SPI_H_TO_L);

setup_wdt(WDT_OFF);

$/{ }^{*}$ Configuração inicial dos Timers *

setup_timer_0(RTCC_INTERNAL|RTCC_DIV_1); ${ }^{*} 16$ bits - Injecao 1,4*/ setup_timer_1(T1_INTERNAL|T1_DIV_BY_1); /* 16 bits - Deteccao da falha * setup_timer_2(T2_DIV_BY_4,255,16); * $^{*} 8$ bits *

setup_timer_3(T3_INTERNAL|T3_DIV_BY_1); /* 16 bits - Injecao 2,3 */

$1 *$ Inicializacao das variaveis - Ignicao */

t_low_ref $=65535 ;$ / $^{*}$ Garante que o pulso de detecção só acontecerá após a comparação do segundo pulso de sinal */

estouro1 = 0

volta $=0$;

dente $=0$;

ig_pos $=0$;

ij_pos $=0$;

ig_tmr2_disparo $=65535$;

ig_dente_23 $=255$; 


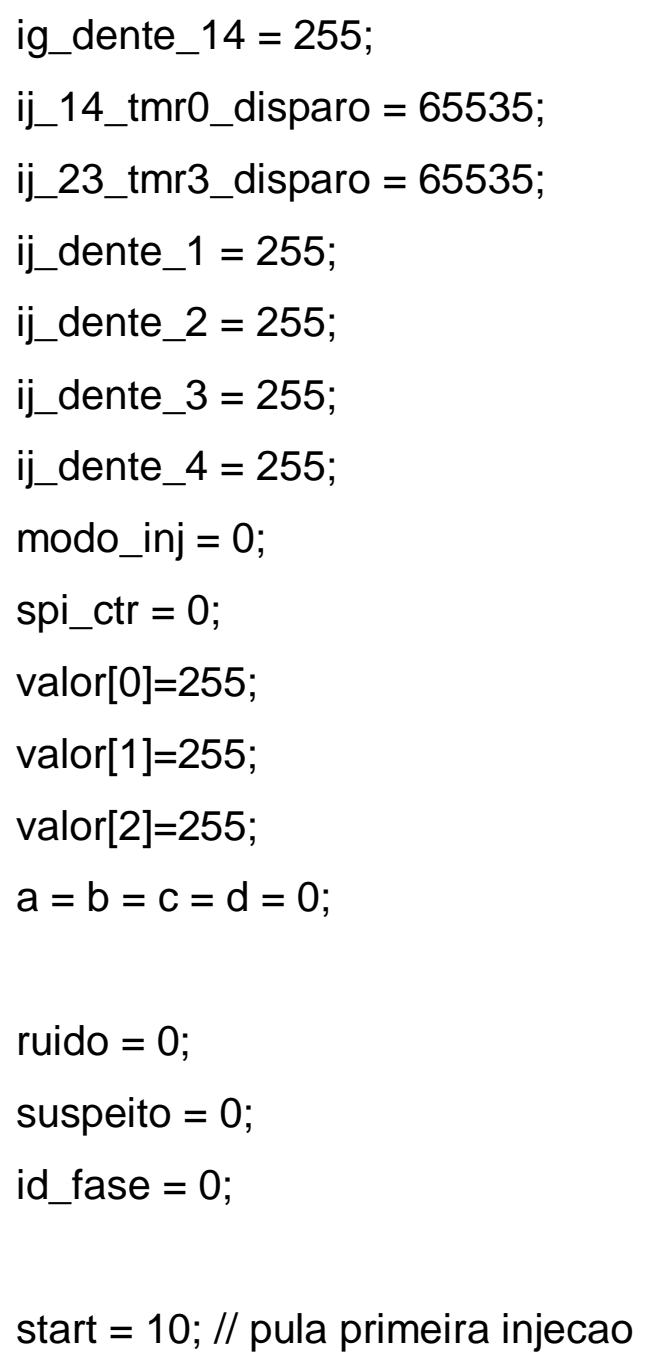

// Desliga Ignicoes e injecoes por seguranca output_low(sinal_ig23);

output_low(sinal_ig14);

output_low(sinal_inj1);

output_low(sinal_inj2);

output_low(sinal_inj3);

output_low(sinal_inj4);

delay_ms(1); // para dar tempo do GER iniciar antes, senao $\mathrm{n}$ funciona

/* Habilita interrupcoes */

enable_interrupts(GLOBAL);

enable_interrupts(INT_EXT); 
output_low(ledsin3);

nivel $=0$;

ext_int_edge(H_TO_L);

pisca_leds(); /* Todos os LEDs ficam apagados apos piscarem */

output_high(LEDSIN1); /* LED de falhas - Aceso no inicio */

output_low(LEDSIN2); /* outros 2 leds apagados no inicio */

output_low(ledSIN3);

while (true);

\} 